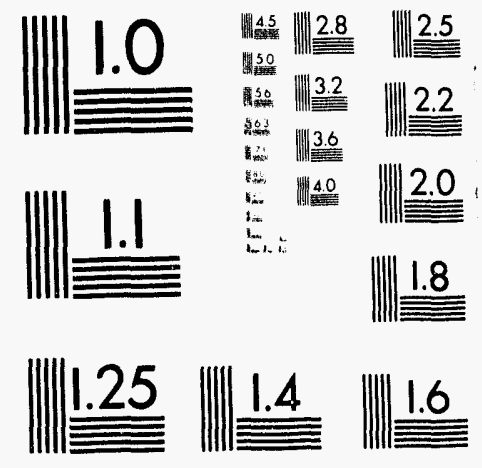



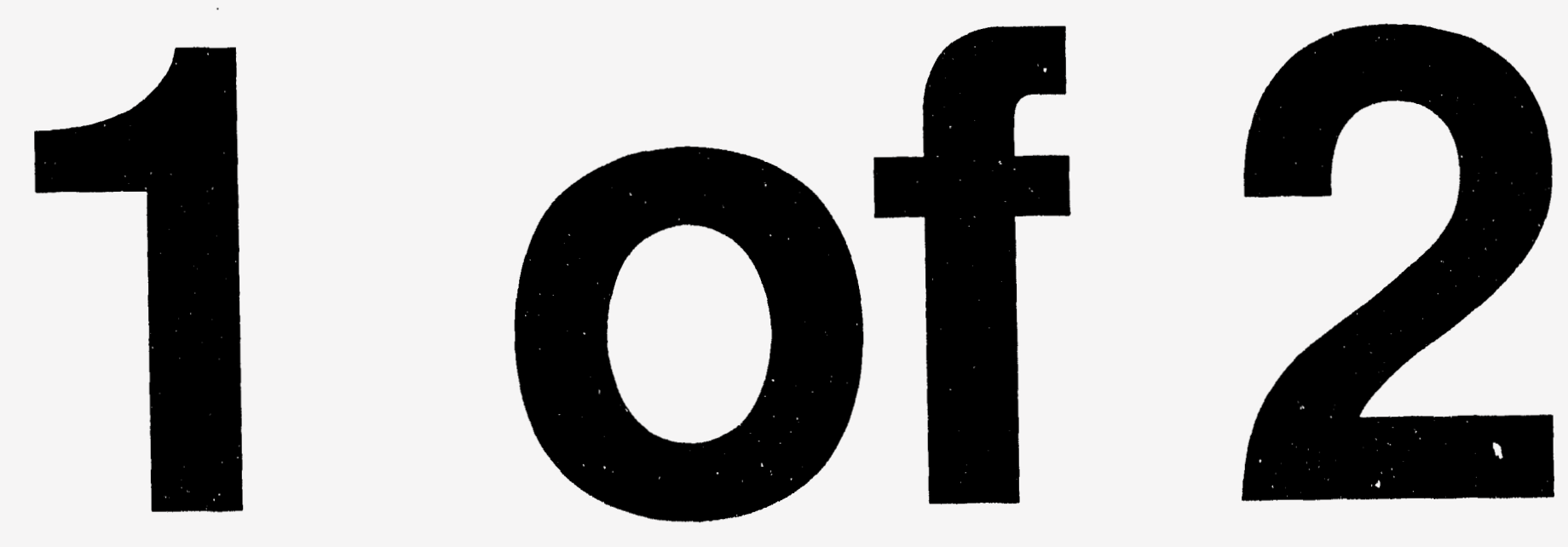


\section{HANFORD PRODUCTION CUT-BACK STUDIES}

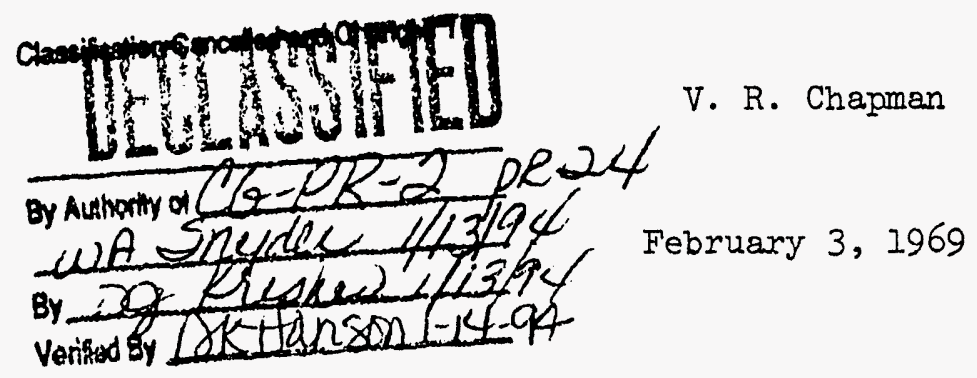

\section{DISTRIBUTION}

1. V. R. Chapman

\section{DISCLAIMER}

This report was prepared as an account of work sponsored by an agency of the United States Government. Neither the United States Government nor any agency thereof, nor any of their employees, makes any warranty, express or implied, or assumes any legal liability or responsibility for the accuracy, completeness, or usefulness of any information, apparatus, product, or process disclosed, or represents that its use would not infringe privately owned rights. Reference herein to any specific commercial product, process, or service by trade name, trademark, manufacturer, or otherwise does not necessarily constitute or imply its endorsement, recommendation, or favoring by the United States Government or any agency thereof. The views and opinions of authors expressed herein do not necessarily state or reflect those of the United States Government or any agency thereof.

$\cdots M E$ IVE

MAR 081994

OSTI
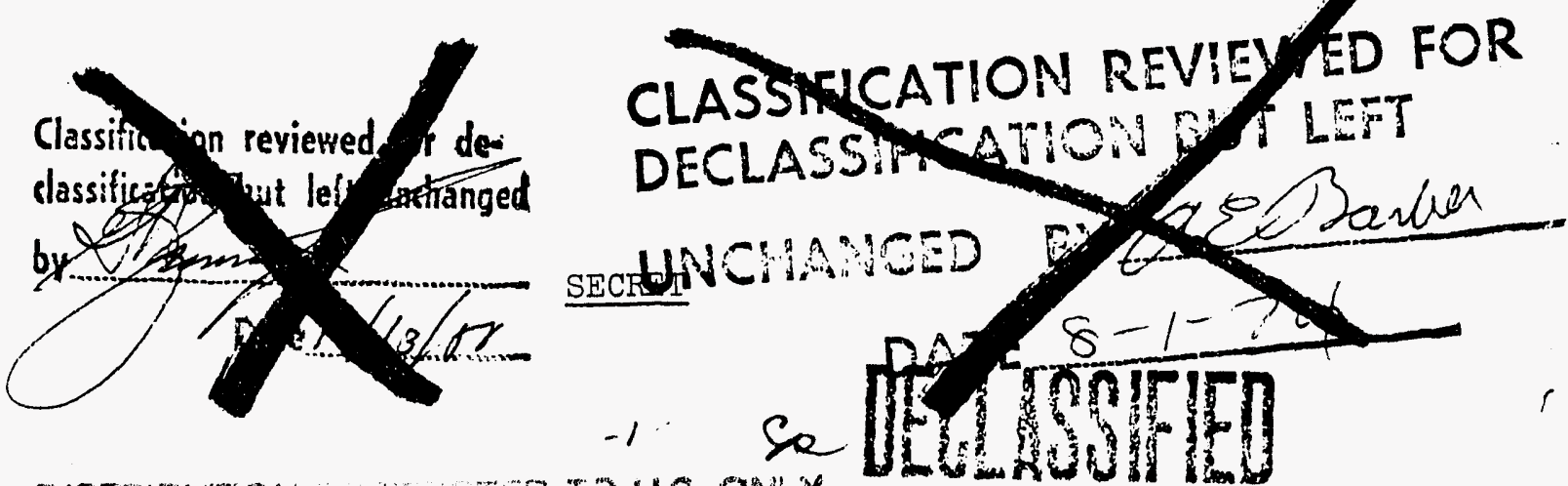


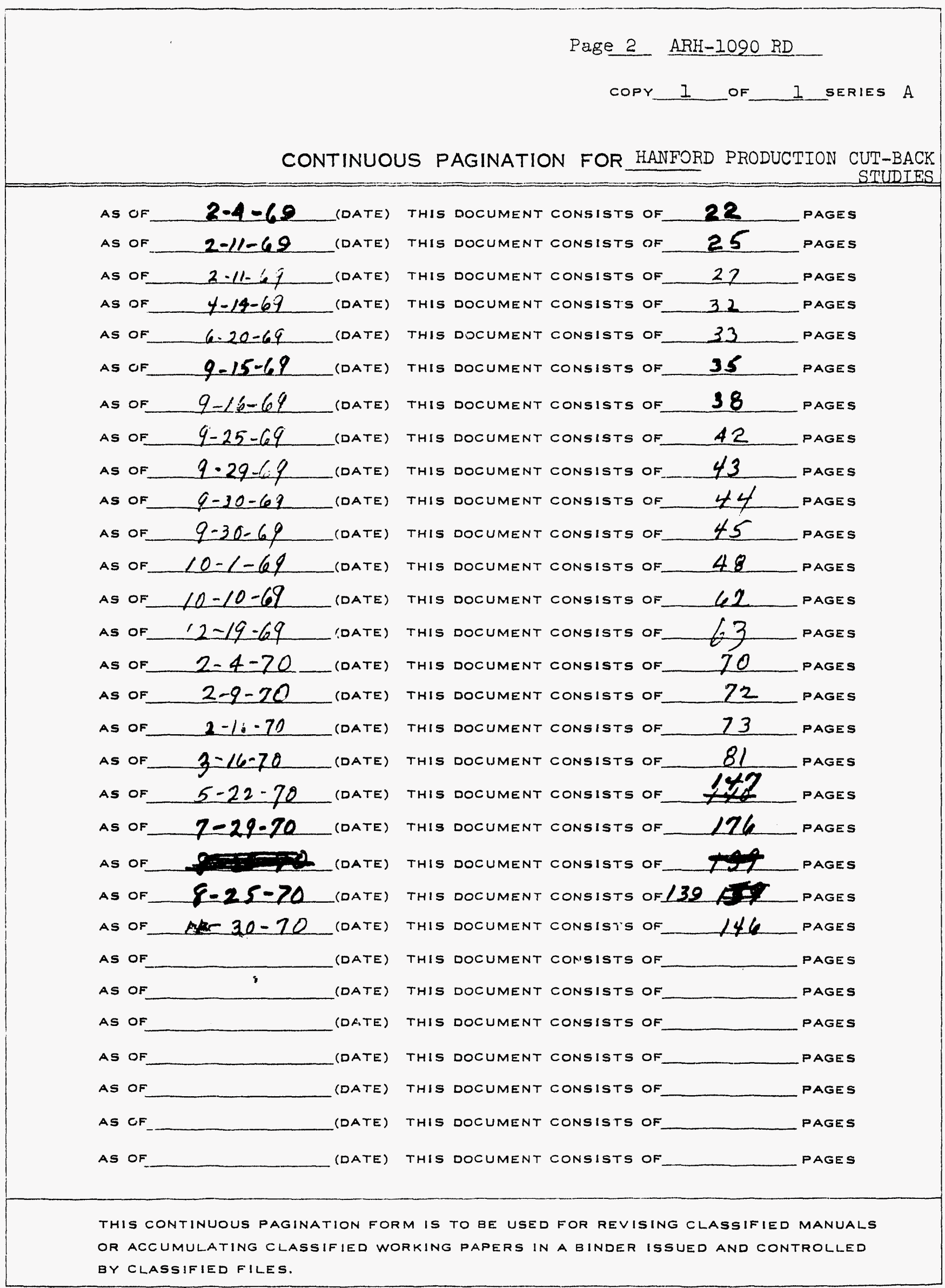




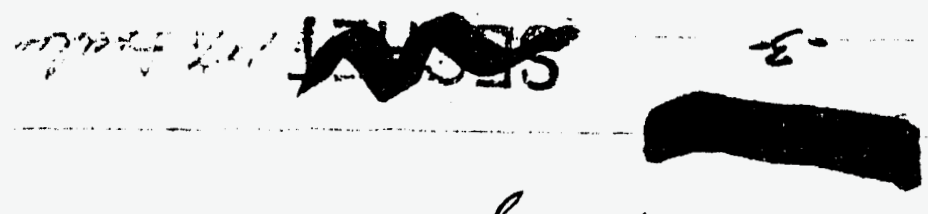

$$
\begin{aligned}
& j^{2 b} \cos \sin ^{\prime} t \\
& \text { 2006'ह }
\end{aligned}
$$

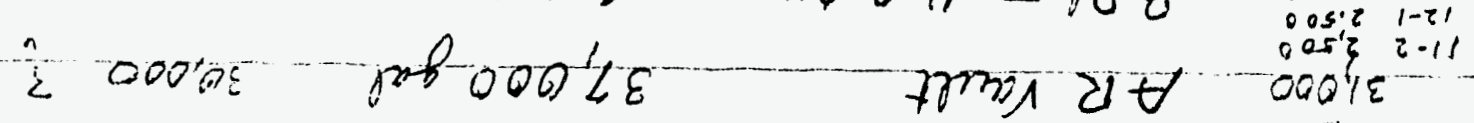

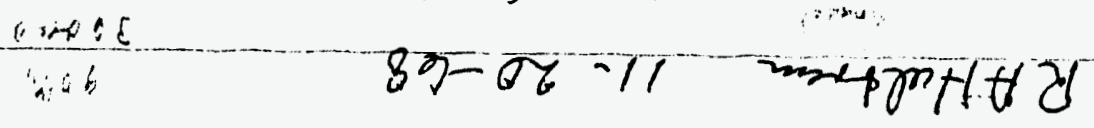

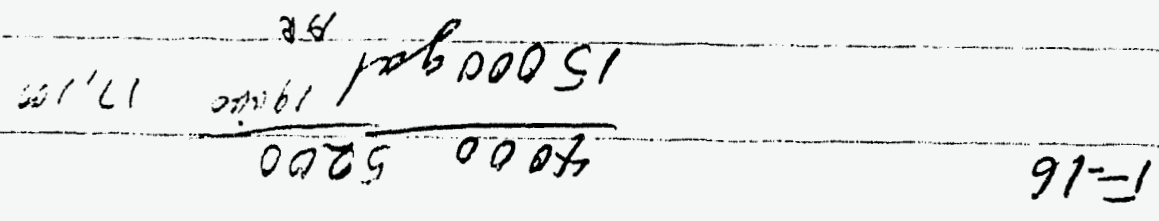

$$
\begin{aligned}
& \text { } 005 \text { op STS } 51 \\
& \text { oors कoxh हा- }
\end{aligned}
$$

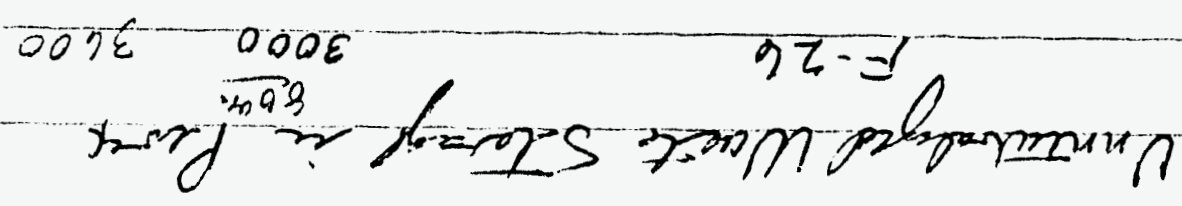

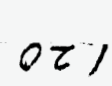

$$
\begin{aligned}
& \text { do5 } 0 \times 2 \\
& 08-0 . \\
& \sqrt{7.9 / 6} \\
& 4 / \text { mas } 0,6 \text { ood } 05 \\
& \text { 2) pobs sti mer }
\end{aligned}
$$

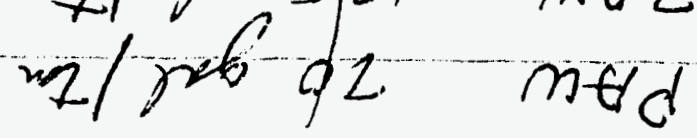

$$
\begin{aligned}
& \text { mang } x \text { ment } \\
& \text { sp-s1-11 } \overline{\text { काpand }}
\end{aligned}
$$

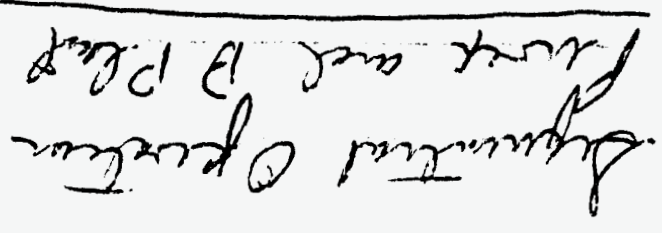


Date: November 21, 1968

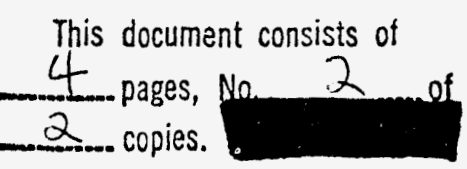

To: M. K. Hermon

From: $\quad \mathrm{R}$ R. Chapman QRRChaysmanes

Subject: PUREX - B PLANT SEQUENTIAL OPERATION

Attached you will find two tables and a flgure that depict a first attempt (by me) to lay out an operating plan for the sequential operation of Purex and B Plant. To develop this plan, it has been necessary to develop assumptions relsting to how much unneutralized waste can be accumulated from Purex before $B$ Plant is forced to mun, the time required to make trangltions between Purex and B Plant, the mode of reactor operation, etc. The assumptions used are shown in Table I.

A fundamental assumption used is that $N$ Reactor will continue to produce 12 percent $\mathrm{Pu}-240$ grade plutonfum and, In so dolng, will process about 600 tons of enriched uranlum per year. Production from the single-pass reactors was then adjusted to 1111 the Purex portion of the sequence that remalns after $\mathbb{N}$ Reactor ruels are processed. This production is equal to the output of the two $K$ reactors with power levels reduced about 12 percent below the nominal $4400 \mathrm{Mw}$ level. Of the 3300 total tons aralleble from the single-pass reactors (it is assumed that all the uranium will contain weapons grade plutonlum), approximately 550 tons would be 94-enriched uranium.

It w1ll be noted that under this plan (Table II and Flgure I) Purex wlll operate 200 days per year. Th1s is equivalent to 4800 tons per year average, based on the processing of Al-clad natural or 94-enrlched urantum containing veapons grade plutonium.

VRC : rmb

Enclosures - 3

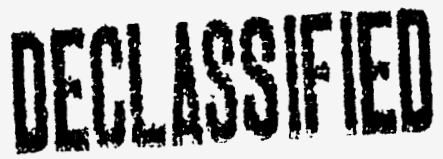

ROUOH DR:-1

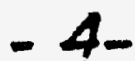


ASSUMPTIONS

1. Waste Volume (Unneutrallzed):

PAW produced

ZAW produced

2. Unneutralized Waste Storage:

Purex Plant

$B$ PIant

AR Vauzt.

Total
70 gallons/ton U processed 125 gellons/ton U processed

3. Average Processing Rates in Purex and B Plant:
Al-clad natural
$24 T / D$
Al-clad enriched
$24 \mathrm{~T} / \mathrm{D}$
Zr-clad 94-125
$10 \mathrm{~T} / \mathrm{D}$
ZAW \& PAW as produced by Purex
$3600 \mathrm{gel} / \mathrm{D}$

4. Five-day transition for each turnaround between A \& B Plants.

5. Length of average month: 30 days

6. IPPR production:

12 percent Pu-240 grade plutonium from MK-I 94 with

125 splke enrlchment. 600 ton U/year.

7. Single-pass reactor production governed by time avallable after $\mathbb{N}$ Reactor fuels processed; will produce weapons grade $\mathrm{Pu}$ only.

8. No thorium processing

9. Two 94-enriched compalen/year; twelve-day turnaround allowed/year

VRC : rmb

$11 / 21 / 68$ 


\section{TABLE II}

PUREX - B PLANT PROCESSING SCHEDULE

\begin{tabular}{|c|c|c|c|c|c|}
\hline Tons & Source & Operation & $\begin{array}{l}\text { Waste } \\
\text { Gallon }\end{array}$ & $\begin{array}{c}\text { Days } \\
\text { Required } \\
\end{array}$ & $\begin{array}{l}\text { Accumulated } \\
\text { Deys } \\
\end{array}$ \\
\hline 300 & NPR 94-125 & $\begin{array}{l}\text { Purex } \\
\text { Transition to B Plant }\end{array}$ & 37,500 & $\begin{array}{r}30 \\
5\end{array}$ & $\begin{array}{l}30 \\
35\end{array}$ \\
\hline & ZAW & $\begin{array}{l}\text { B Plant } \\
\text { Transition to A Plant }\end{array}$ & 37,500 & $\begin{array}{r}11 \\
5\end{array}$ & $\begin{array}{l}46 \\
51\end{array}$ \\
\hline 825 & Natural & $\begin{array}{l}\text { Purex } \\
\text { Transition to B Plant }\end{array}$ & 57.750 & $\begin{array}{r}35 \\
5\end{array}$ & $\begin{array}{l}86 \\
91\end{array}$ \\
\hline & PAW & $\begin{array}{c}\text { B Plant } \\
\text { Transition to A Plant }\end{array}$ & 57,750 & $\begin{array}{r}16 \\
5\end{array}$ & $\begin{array}{l}107 \\
112\end{array}$ \\
\hline 825 & $\begin{array}{l}\text { Natural } \\
94 \\
\text { Enriched }\end{array}$ & $\begin{array}{l}\text { Purex } \\
\text { Turnaround } \\
\text { Transition to B Plant }\end{array}$ & 57,750 & $\begin{array}{r}35 \\
6 \\
5\end{array}$ & $\begin{array}{l}147 \\
153 \\
158\end{array}$ \\
\hline & PAW & $\begin{array}{c}\text { B Plant } \\
\text { Transition to A Plant }\end{array}$ & 57,750 & $\begin{array}{r}16 \\
5\end{array}$ & $\begin{array}{l}174 \\
179\end{array}$ \\
\hline & & Idle & & 1 & 180 \\
\hline
\end{tabular}

SUMMARY

ANRUAL BASIS

\begin{tabular}{|c|c|c|c|c|c|c|}
\hline \multicolumn{2}{|c|}{ Purex } & \multicolumn{2}{|c|}{$B$ Plant } & \multirow[b]{2}{*}{$\begin{array}{l}\text { Trans1- } \\
\text { tion } \\
\end{array}$} & \multirow[b]{2}{*}{$\begin{array}{l}\text { Turn- } \\
\text { around }\end{array}$} & \multirow[b]{2}{*}{$\begin{array}{l}\text { Total } \\
\text { Days }\end{array}$} \\
\hline 208 & Days & $\begin{array}{c}\text { Gal } \\
\text { Weate }\end{array}$ & Days & & & \\
\hline 600 & 60 & 75,000 & 22 & 20 & - & \\
\hline 3300 & 140 & 231,000 & 64 & 40 & 12 & \\
\hline$=$ & $=$ & $=$ & $=$ & $=$ & $=$ & \\
\hline 100 & 200 & 306,000 & 86 & 60 & 12 & \\
\hline
\end{tabular}

Purex equivalent capacity 200 op days $\times 24 \mathrm{~T} /$ day avg rate $=4800 \mathrm{~T} / \mathrm{yr}$ VR Chapman/rmb $11 / 21 / 68$ 


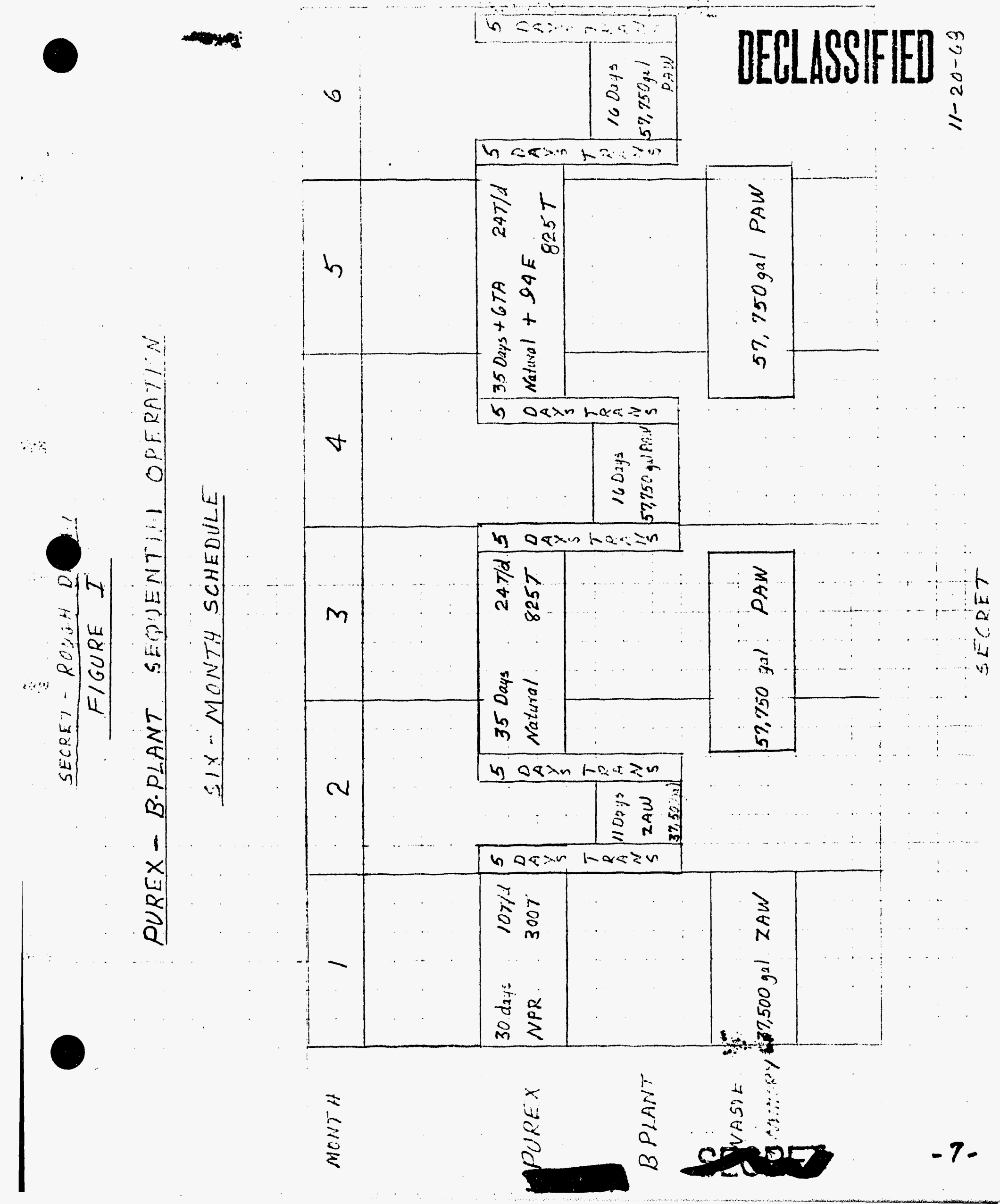




\section{8unter}

\section{Distribution:}

1. M. K. Harmon

2. Circulate/

V. R. Chapman

Date: January 24,1969

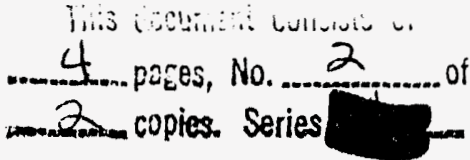

To: $\quad$ M. K. Harmon

From: V. R. Chapmen

Subject: PUREX - B PLANT SEQUENTIAL OPERATION

You have a secret rough draft copy of "Purex - B Plant Sequential Operation" wh1ch I issued on November 21 , 1968. In the light of the recent developments, I've had second thoughts about the optimistic rates used for the processing of $\mathrm{N}$ reactor fuels through Purex. The optimistic rates were based on capital expenditures proposed in CAGE studies; these expenditures have little chance of tak1ng place under present trends. As a result, I've reworked the production tables using Purex throughputs that we currently use in the Quarterly Production Forecast. Th1s results in more days consumed in Purex for $N$ reactor fuel processing with less time left to process LP reector ruels.

The revised tables and charts, which are enclosed, are probably more interesting than they are useful, since they are based on $\mathrm{N}$ reactor producing 12 percent Pu-240 grade plutonium. After we get a little better $f 1 x$ on future reactor operating mode, I will rework the charts hoping to be closer to the real world. In the meantime, you may want to compare Figure I as it appesis in this document and the previous one.

VRC : rmb

Enclosures

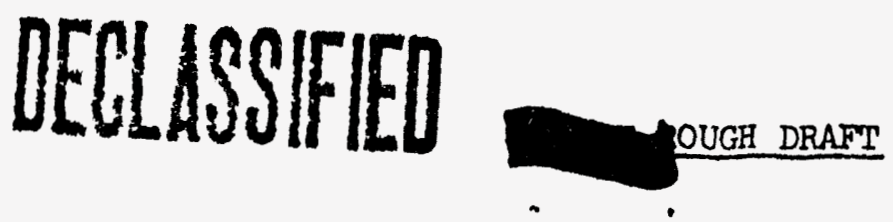

$-8-$

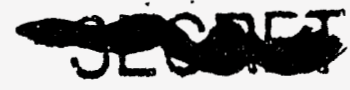


TABLE I

ASSUMPTIONS

1. Waste Volime (unneutral1zed) Produced

PAW

ZAW

70 gallons/ton U processed

125 gallons/ton U processed

2. Unneutral1zed Waste Storage

\section{Gallons}

Purex Plant

15,000

B Plant

6,000

AR Vault

TOTAL

37,000

58,000

3. Average Processing Rates in Purex and B Plant

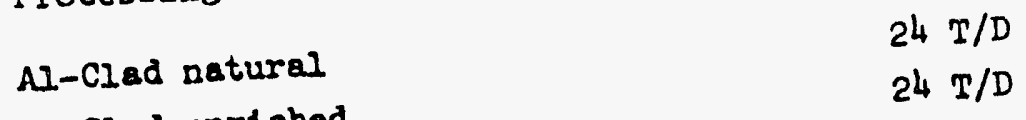

Al-Clad enrlched

$6.7 * \mathrm{~T} / \mathrm{D}$

Zr-Clad 94 comblned with Spike

Unneutrellzed PAW and ZAW Wastes

$3600 \mathrm{gaI} / \mathrm{D}$

* Average rate for 94 is $7.2 \mathrm{~T} / \mathrm{D}$; for $94-125$ spike, $5.2 \mathrm{~T} / \mathrm{D}$; combined, $6.7 \mathrm{~T} / \mathrm{D}$

4. Five-day transition for each turnaround between A \& B Plants.

5. Average month 30 days or 360 days for year.

6. Production from $\mathbb{N}$ reactor assumed to be 600 tons/year containing plutonium with 12 percent Pu-240.

7. Single-pass reactor production adjusted to 3480 tons/year total uranium contalning weapons grade plutonlum.

8. No thorla processing.

9. Two 94-enrlched processing compaigns per year requiring 12 days total turnaround time.

VRC : rmb

$1 / 24 / 69$

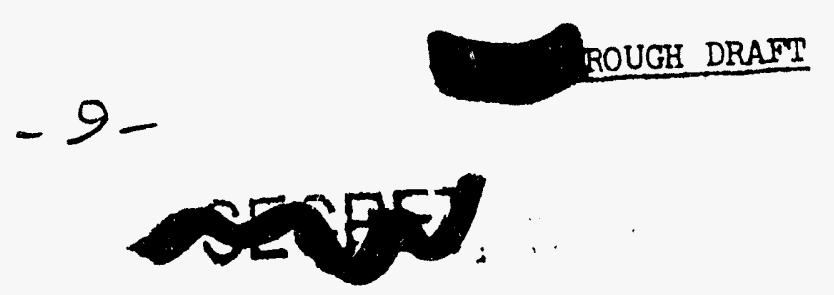



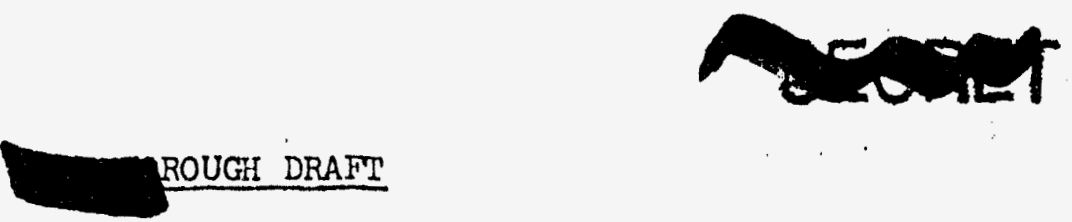

DECLASIFIED

TABIE II

PUREX - B PLANT PROCESSING SCHEDULE

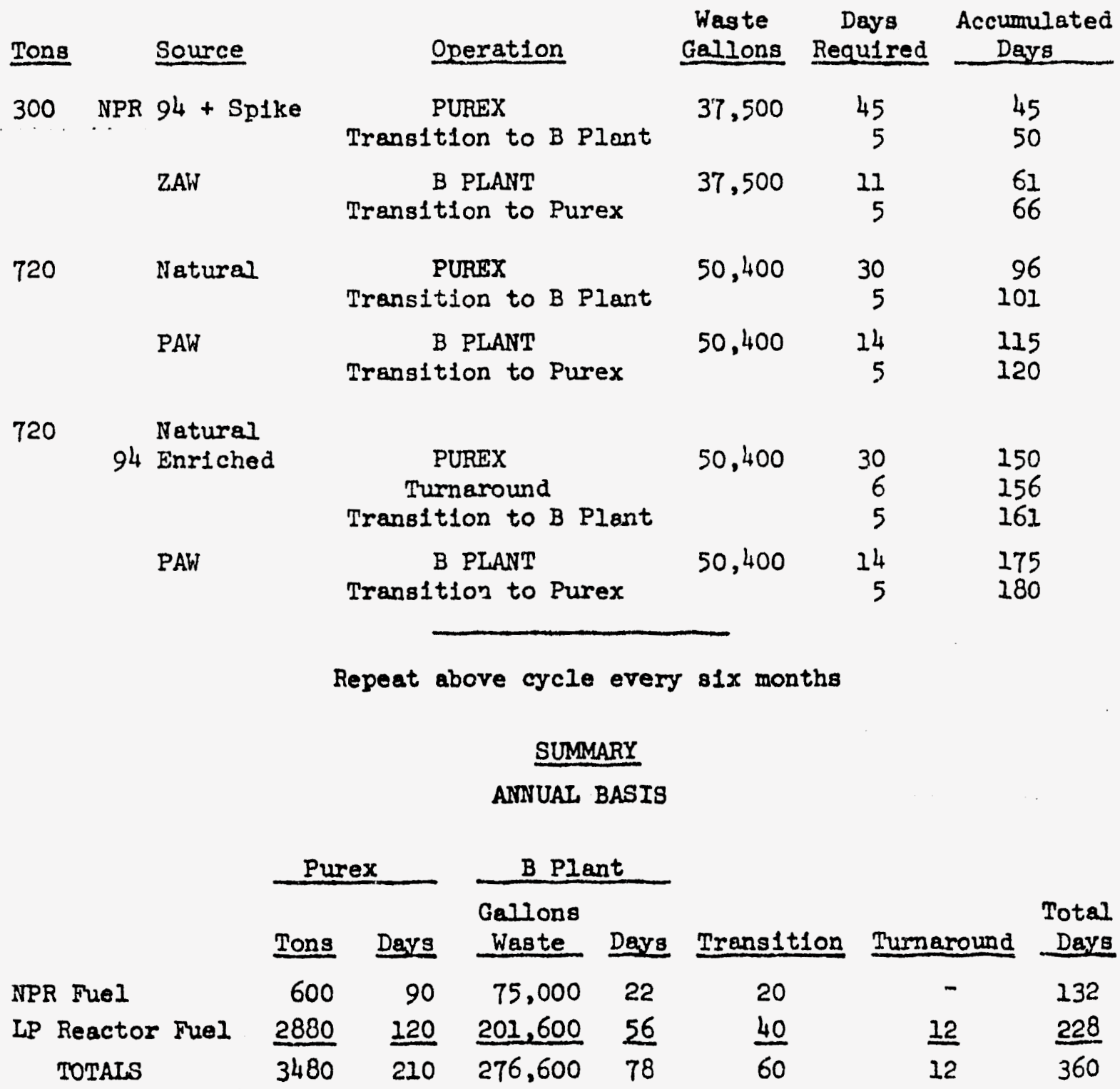

Purex available equivalent capacity: 210 operating days $\times 24$ tons/day average rate $=5040$ tons $/$ year.

VRC $: r b$

$1 / 24 / 69$

$$
\begin{aligned}
& 7 / 12 P_{x} \\
& 90 \quad 3 / 12 \text { BP } \\
& 360 \quad 3 / 2 \text { iver }
\end{aligned}
$$
ROUGH DRAFT
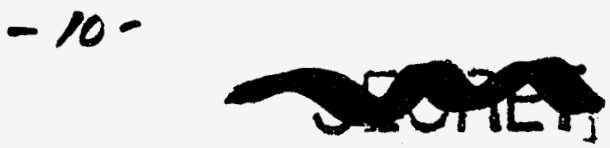
UNCLASSIFIEP

$:-28-69$

Segecisitear Opiration

Cimmiltic

$$
\begin{aligned}
& \text { Cortmell Cunwell } \\
& \text { Rolvers Chapmen } \\
& \text { Deal }
\end{aligned}
$$
The initial metting of thio group wis held in the Pures boferemes. of the time was apent in grasping for an upprosech and sudid

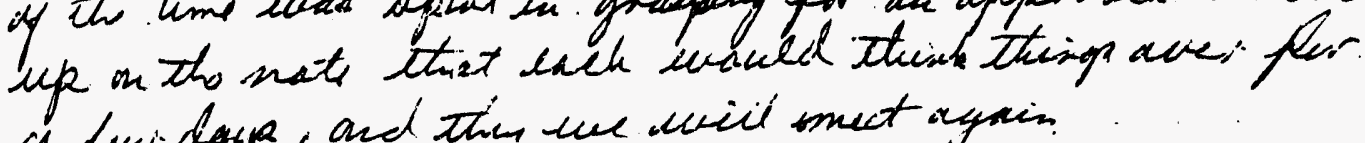
a few doup, and thin we wili mect ayain.

2timas disenese

1. Cmaider lag atring fo-

$$
\begin{aligned}
& \text { Wase } \\
& \text { UNH } \\
& P_{4}
\end{aligned}
$$

2. Stundly frice receumenusity

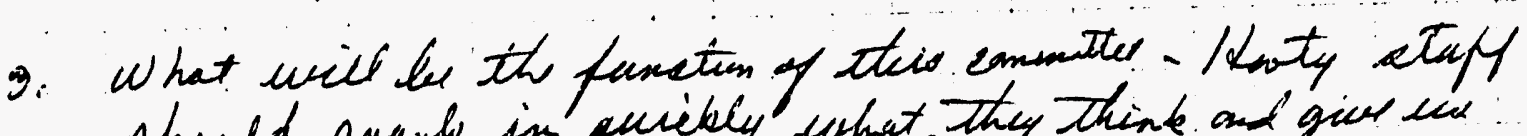
sheuld crask in quickly. What thes thinte and give en

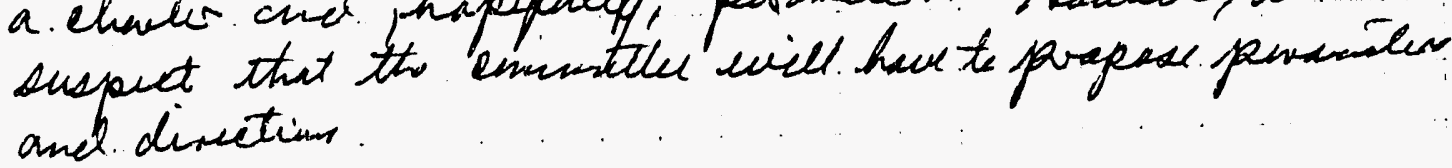
4. Eurved is mecepture and faurs encking the Redex and

5. The thraght that 5-day weck aperatie may be an initial ent linek step for Puses.. Five day weeck oporation deseres tisting in the plinet i. I went through sme of my prelinimeng avalyeis of

UNCLASSIFIED 
-1 - MCLASEIFI

$1-29-49$

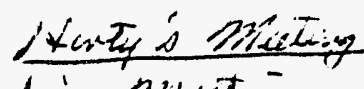

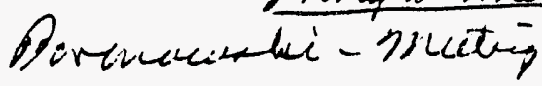

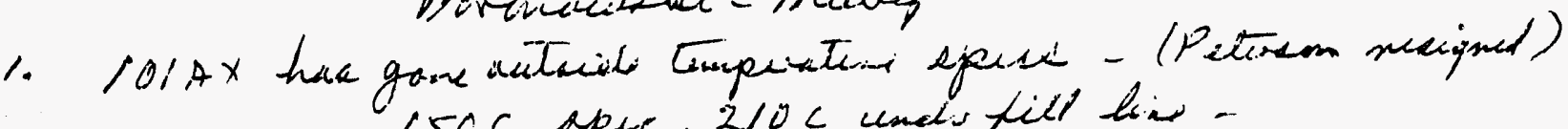

$150 \mathrm{C}$ spece. $210 \mathrm{C}$ unds fill him.

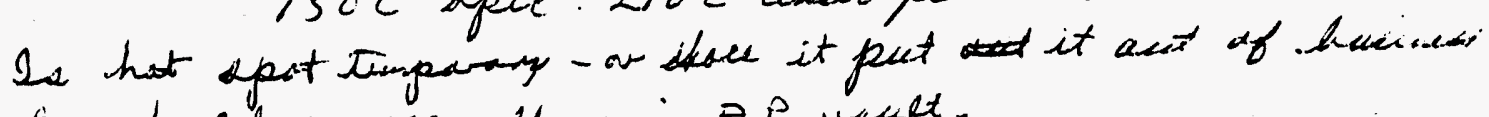
Cone haed 20,000 yallow in $A R$ wacket.

2. ITS stude What one altionate - con we main

3 Aoncopoulater. Shaw

4. SX air cuoling - aw evalucters is ges.

5.. Deps weat: - dateanen

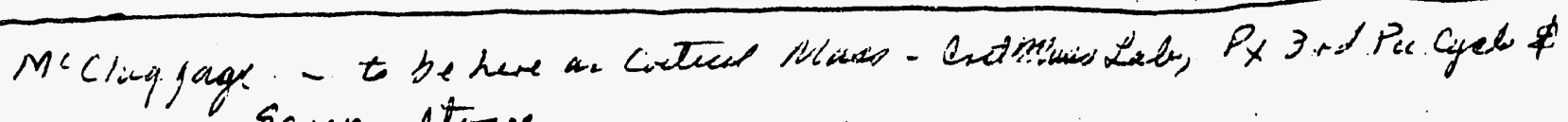
sciap strage -

Syuntixl Opentions

Tas mun ettrelur migled get genersted-

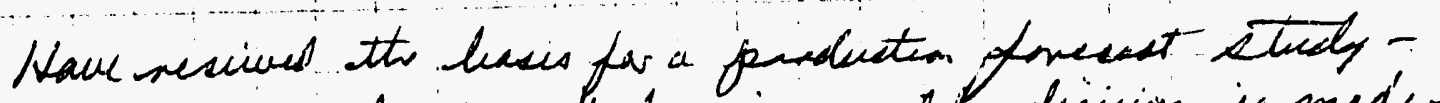
New funcenst hesis curt he given untel a dicision is madeTo car ant und of Mweh-and a 5-yen frecast.

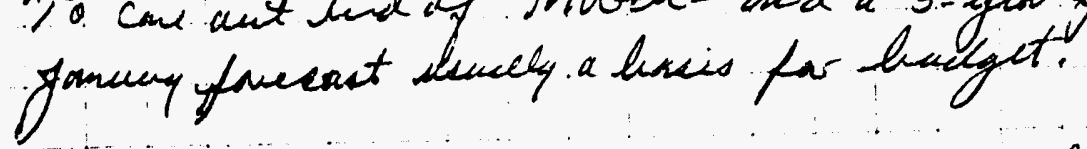

175 dey couling tt. AEC wante - (Elget). Olgut dala nat wint us to cone 1.125 deye uoclaterely

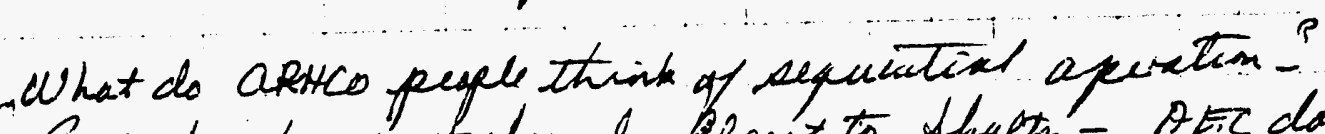

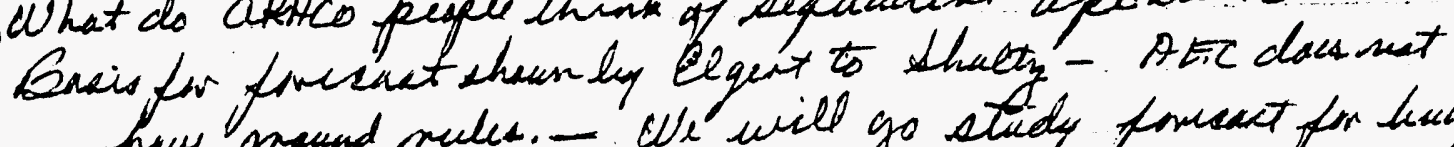
have graund ruelex. - We will go study frment for heselget

AEC

1. Supueteal Bty

2. 5 dey $P x$

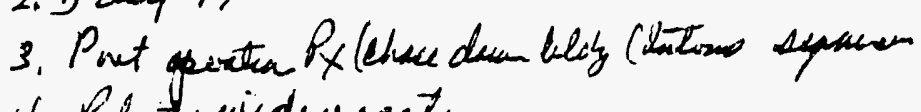

4. Plun wide veceter

5. Raving Mainction.

UNCLASSIFIED

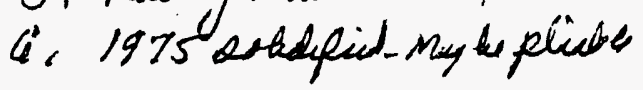

-

$-13-$ 
ANCLASSIFIED

Mimaxifuchion

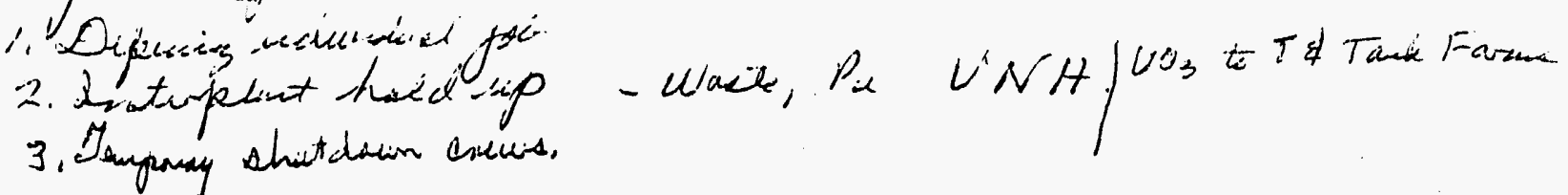

Opvation

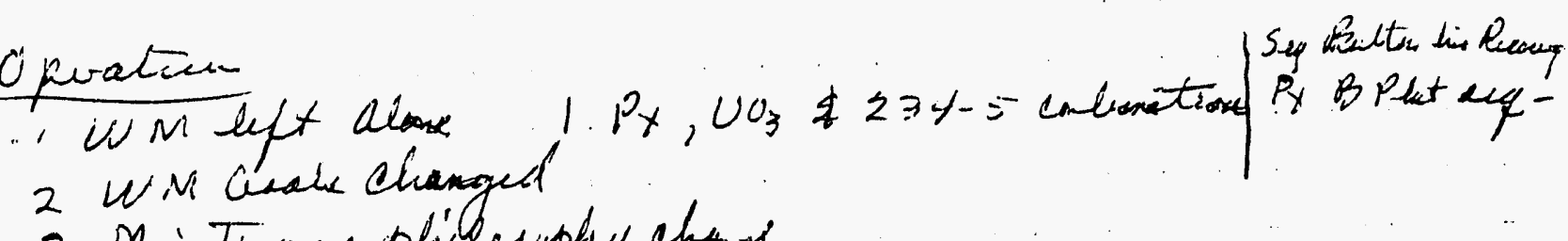
3 Maintions phichesuphy chage to Orgaryation chang

Lew to lase at had

Lant at NIW Gask

Minnturance philasephy

5 dey Puve

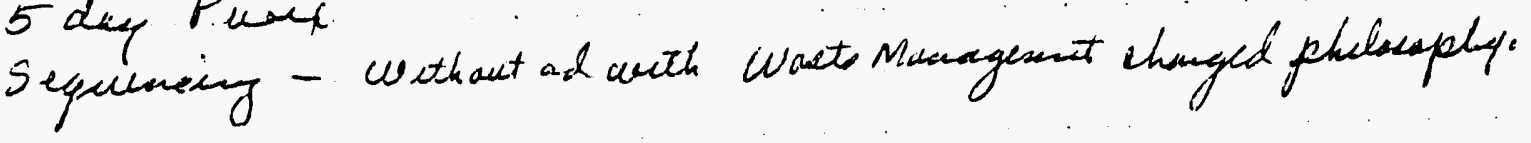

ptatic

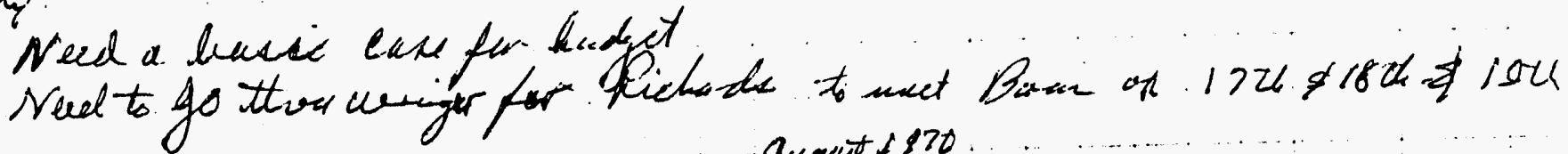

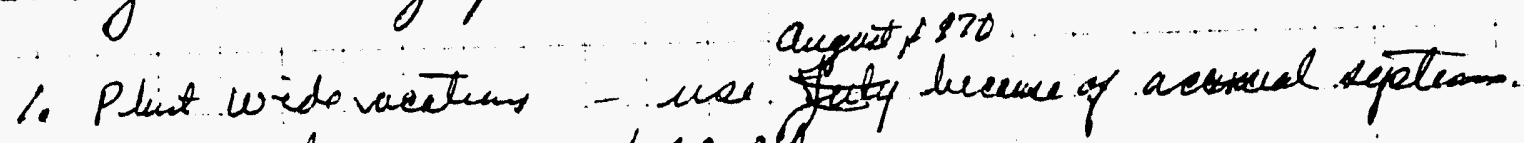
show miny oquel.

2. Raving Minint.

Buecte

RDT netimer -

ZPPR return-

Activitim of backlempl serap the.

change of fued to DF -

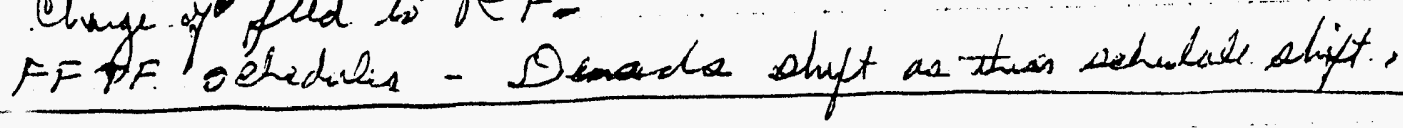

100 Summan

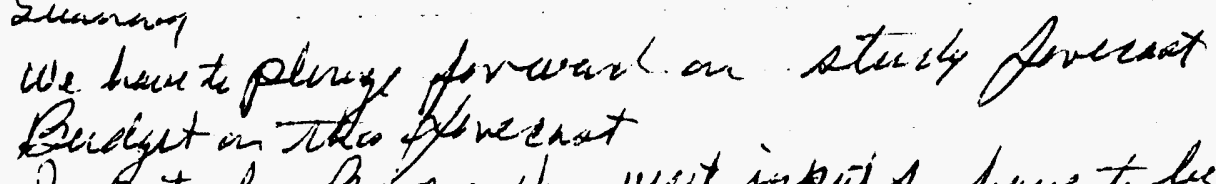

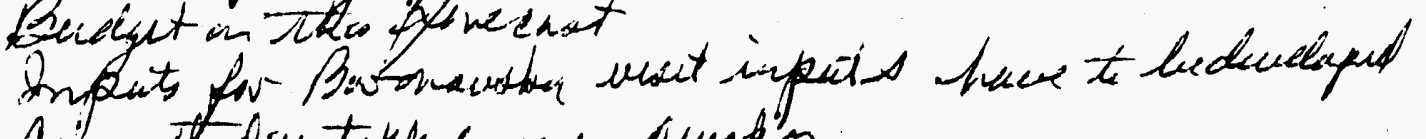

Cike studer tikk fure was wath

". plise wiciluark an.

UNCLASSIFIED

74- 
UMRLASSIFIED

Mic Simingh

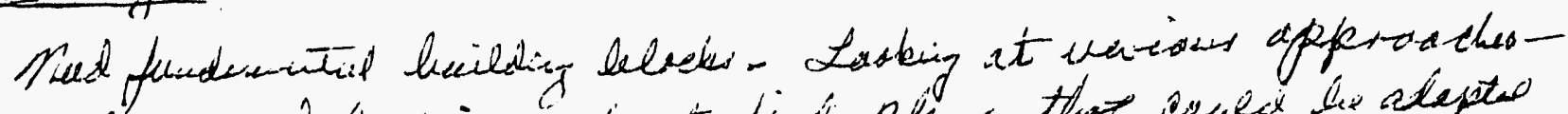

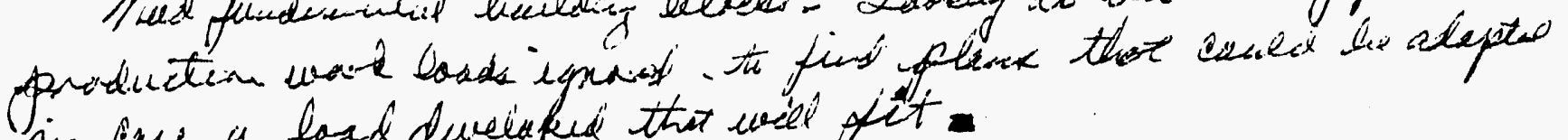
in case a lasd dureiafed that wiet fit

Somith

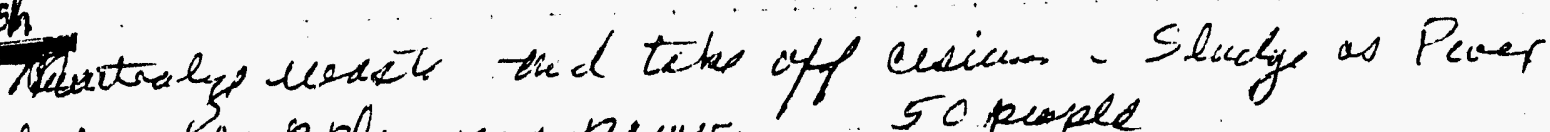

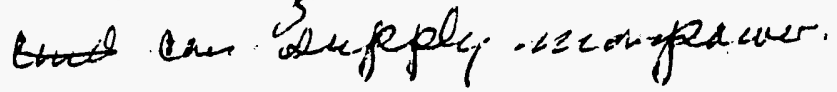
50 people

Libaretore

Insedidation ar shefting people lueb \& forth.

Dables

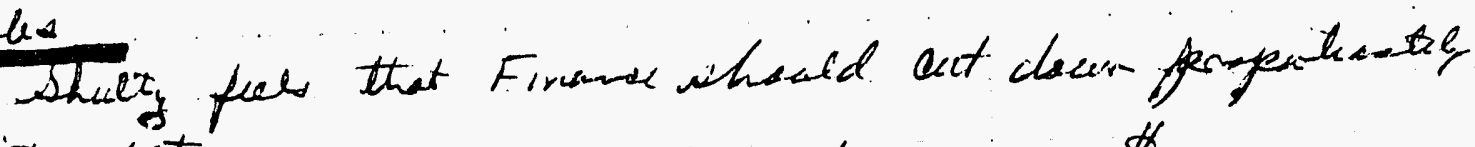
with rest.

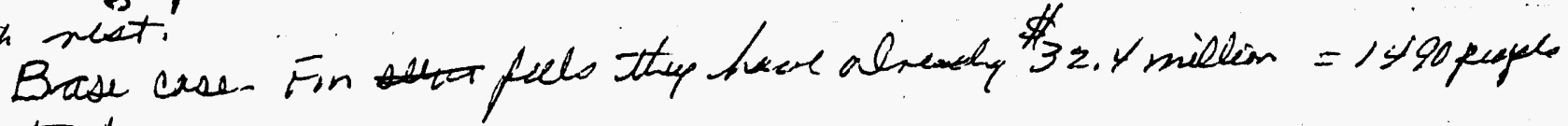
le thasedes

(Naty thach stades wiel be deretes 20.1971 \$ 1972)

GAO has looked at spow pawt and prosed $P E C$ Spare pents cataloy.

PROPOSAL - HART'.

TASK FORCE

1. List the types of studies that sheued he dere and.

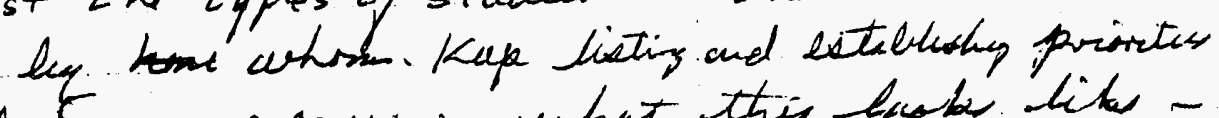

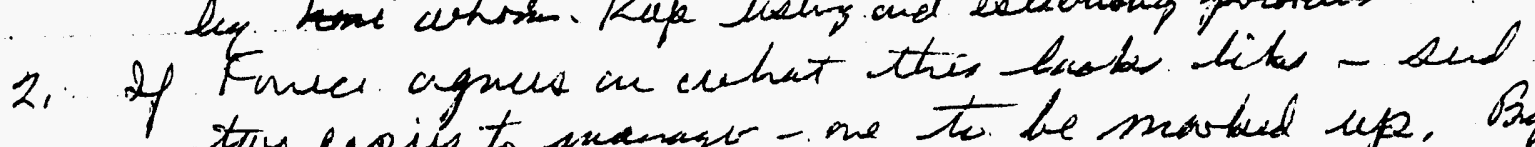

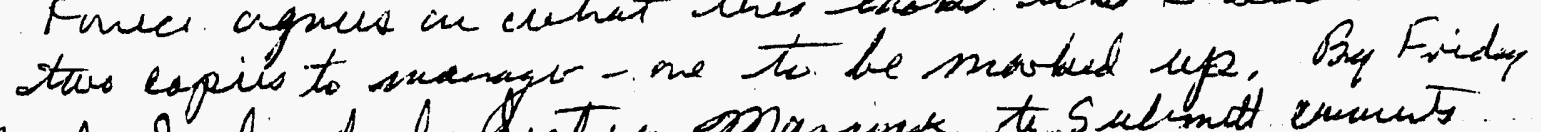

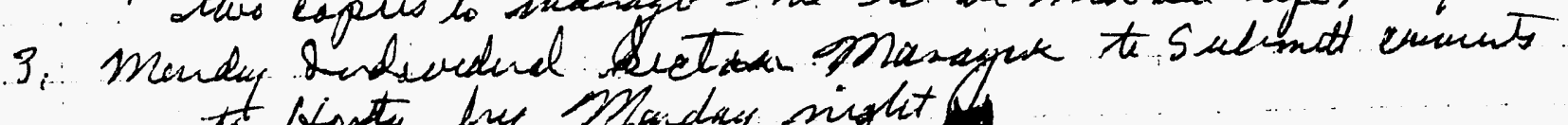

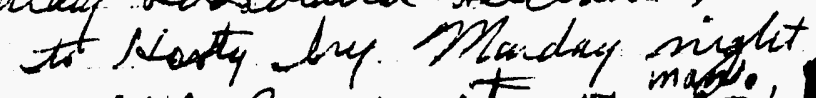
4. Siguential $B$ ase straw in 1

- 2to a deffirult sulject-Gets lietter defined as we go dlong.

UMCLASSIFAED 
UNCLASIFIED

Fancing 30,1964

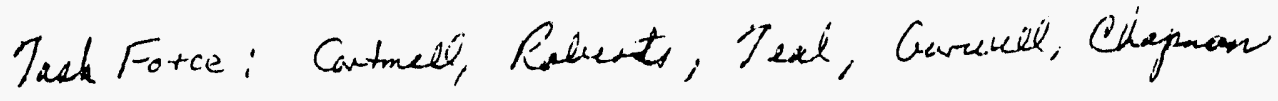

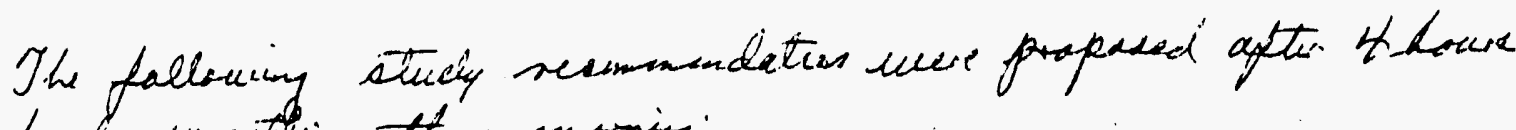
of hand-wresting ther morning:

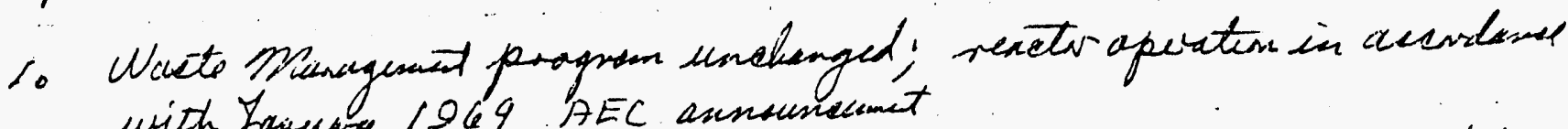
with Jainew 1969. AEC axnounusumet

Stady by

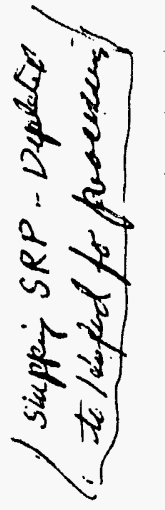

a. 5-duy wack Puex pliat apoiation

Punet

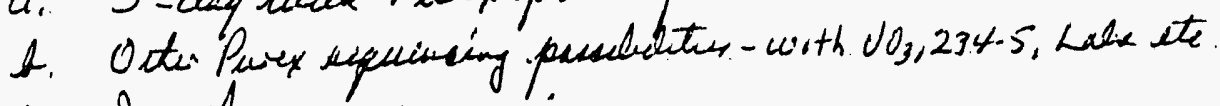

Pures \&R Punt

c. on stouse equening

d. All vacitions in enguet

Rupsetur Plento

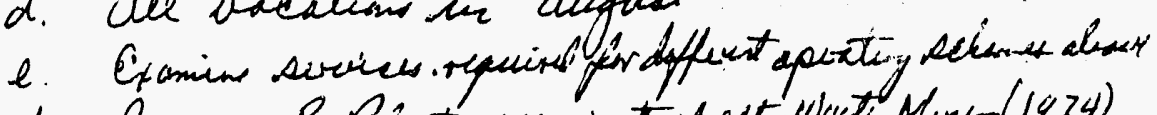

Rupueture pelents-intigates

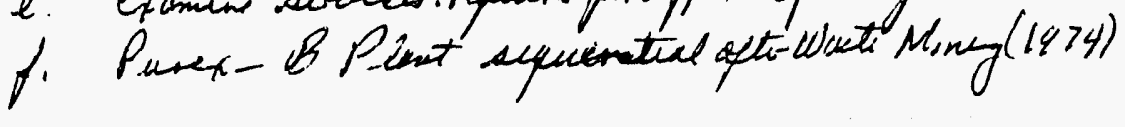

Hicay

Tush Fored

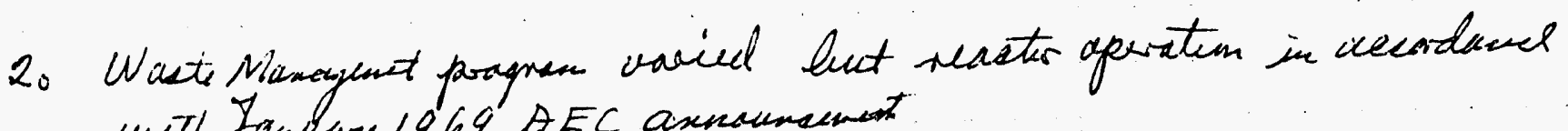
weth Jouclay 1969 AEC axnounsemet

a. Sequintial B plent and Puses

Purex $\&$ B Plad

b. Five dey Purex and /ow BPhat.

c. In hause sequensing

$d$ All vacation in August

d. Evanin sericen te fet eveh ease

Putex $q 8$ Plunt inleysutio. all that indipendet Oel Blents - entepustus macay

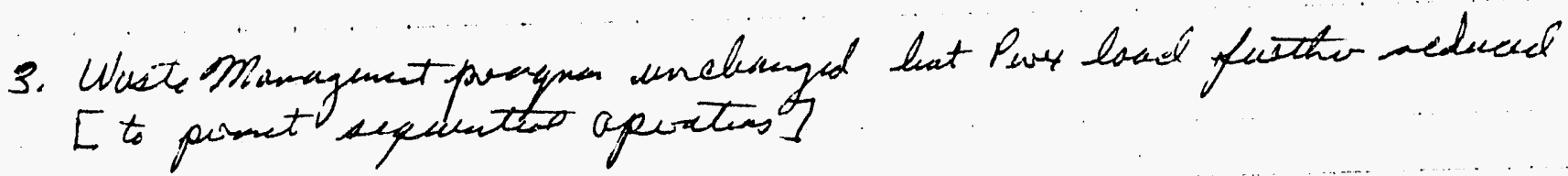

Stur. 1 is lagical ferst priarits since it gets ns on the way to making ecuarnies dury poducten transiten peried and wettin the producter pelow state hy AEC in franviny 1969

Stm 2 is next logieal priving, sined it woudel respind to a call te see haw ravey caned he sased by hard clecesum bat fiaid Piven lrad.

$-41$

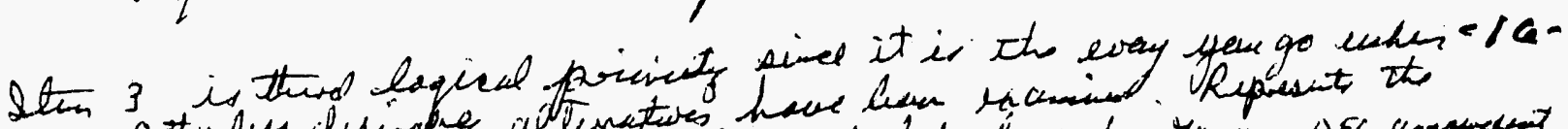

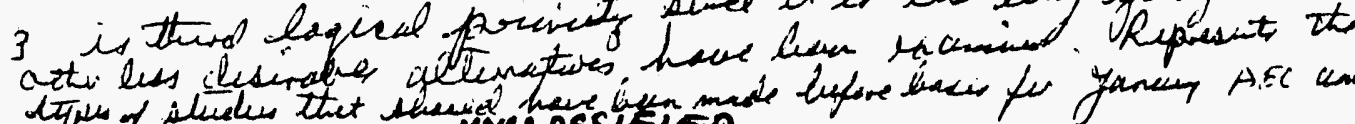

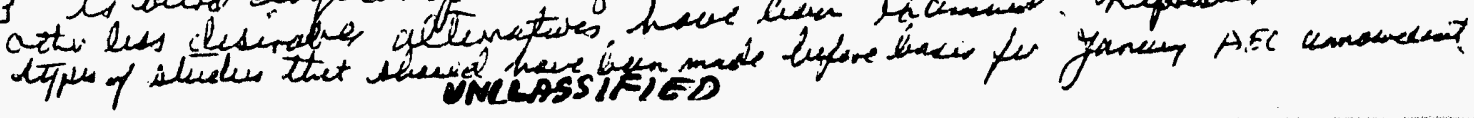




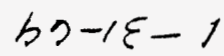

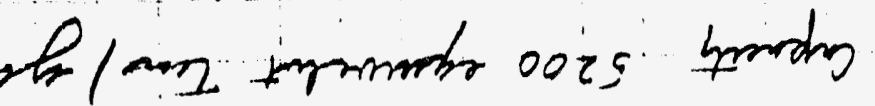

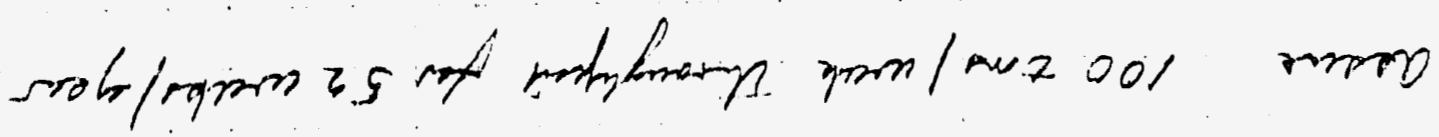

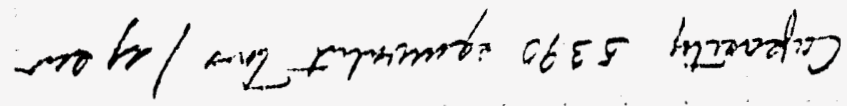

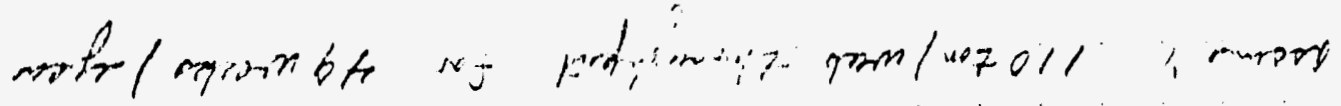
$0235 \cdot 72731$

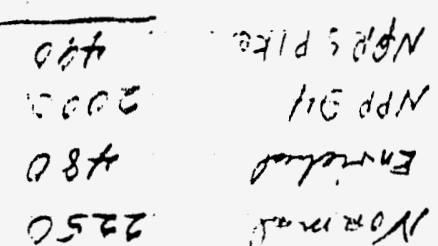

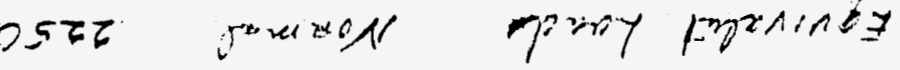

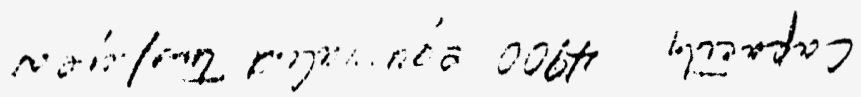

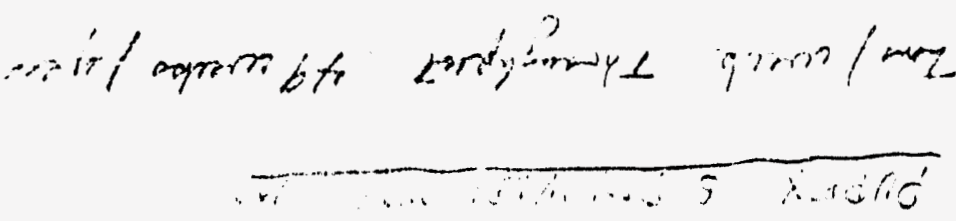


Tox SOn

380 NPR $94 \$ 5$ pik?

ZAW

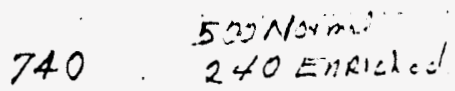

PAW

625. Normaj

PAW

380 NPRO4 3 SPIt.

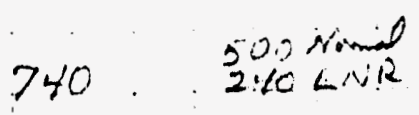

625 Nonmel
WH: $Y=$

a.t.

47500

47500

B Plint:

TRANT.

Purey

TRANS

$B$ Plent

TRANS

purex

TRAN:

BPlat

TRANS

Puive

TRAMS

B Find

TRANS

- Puren

TRANS

BPlant

TRANS

Purey

TRANS

BPlat

TRAIVS

51800

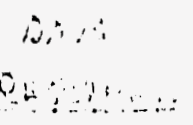

$15 \div$

57

57

5

02

14

5

76

$8 !$

51900

$33(\operatorname{lnc} \mid 2 T H)$

11.4

5

119

15

134

5

139

43.750

26

5

165

170

12

5

182

187

244

57

5

249

4750

14

263

5

$33(1.12 / 2 T A) 30.1$

5

30,6

51800

1.5

321

5 .

326

43250

26

352

5

$35 ?$

$43>50$

12

309

374.

$$
1-31-69
$$




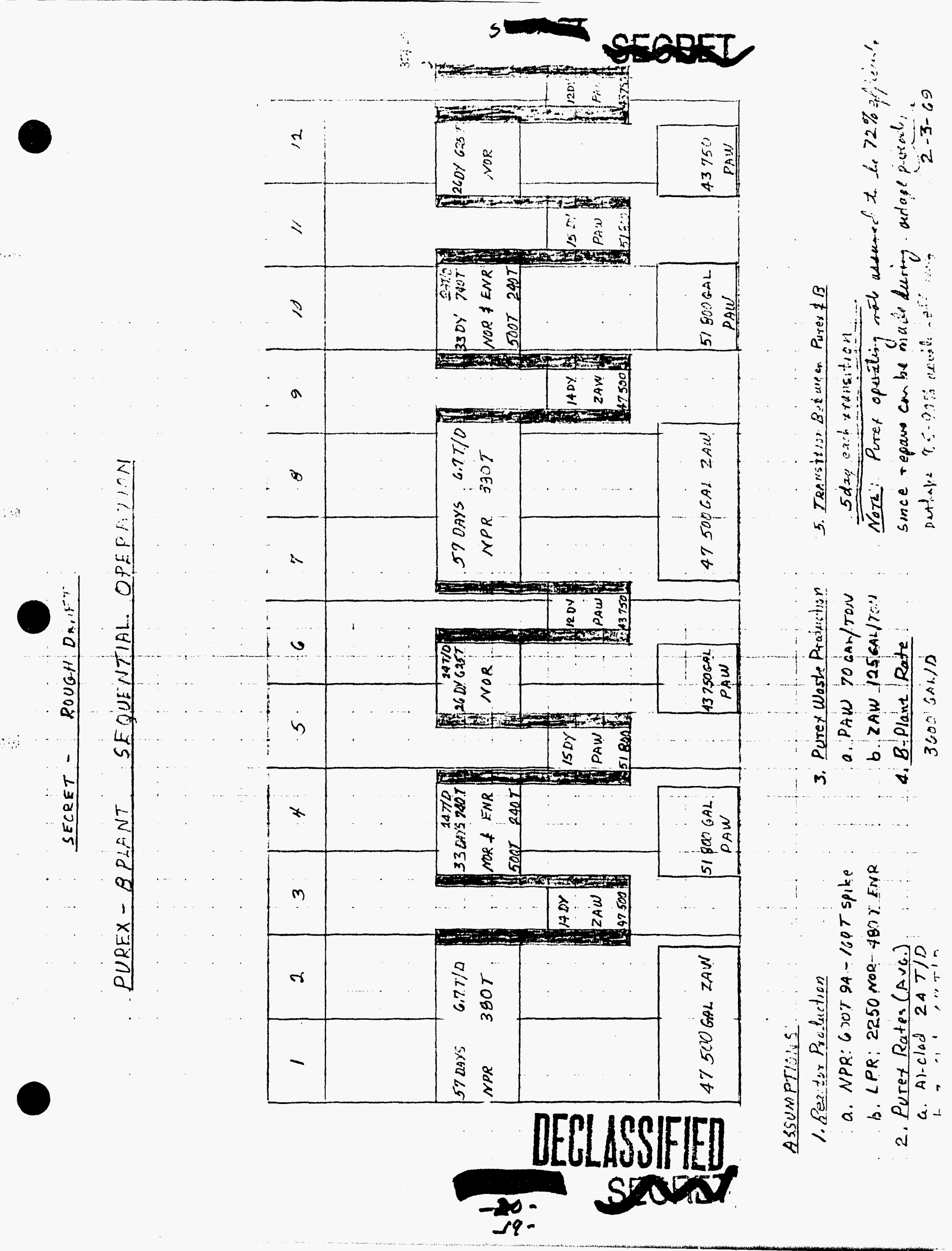


UNCLASSIFIED

Pyre l India

E Plan: Idle

Transition

Total check $\frac{60}{374}$

Question: What use to make of idle time.

Io The first solution that will be of fined: marian fuel Crees at B Plant- Rotate floaters between Purer and tank farm mining operations. This not very good because tank farm would get people oily 8 I days per year

2. A better approach but cumbersome to manas a) Flout a crew between Purest and B Plant to manufacture and process unneutralized PAW $\$ Z A W$; and

b): Float another crew between B Plant and thant form mining during the 182 days Buret has the floating crew.

FOR calculations, Need sound number far Gal $P A W /$ th .791-clad U processed! Gel Zaw/zn Zn-clad U presses?

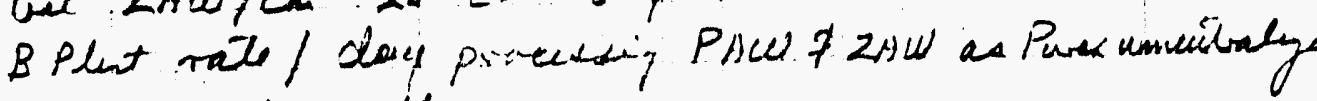
waste gallons.

Unneutidiace. PAU ardor 2DUS storage capacity, A determiner of Purer. T) day average vat levering

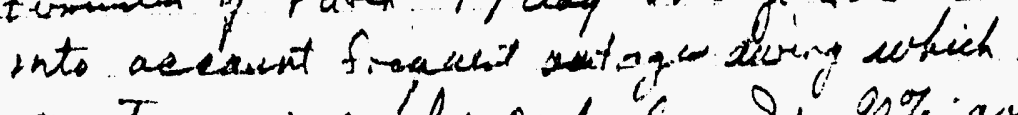
mantionares con' be performed. $2490 \%$ acred

At what Rate Sw PAS be ritivenes?

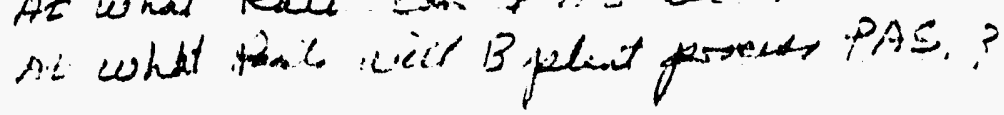

Min- Laces:

Pure Waite From

BOLA UNCLASSIFIED

$2-3 \cdot 1,9$ 
UNCLASSIFIED

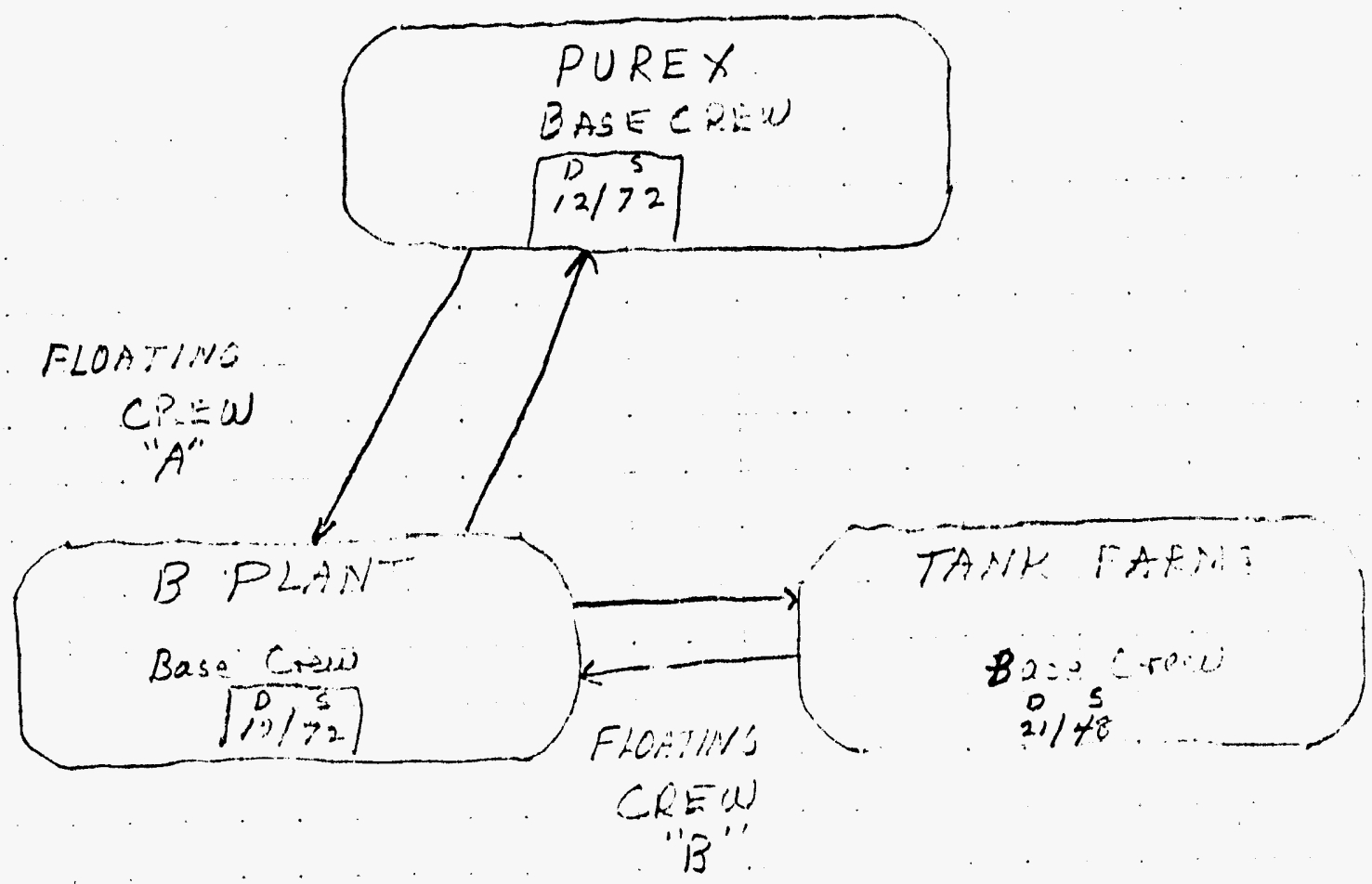

FLOATHIS CREW "A"

10. Add to Purex base craw te operate Pures (2320ays)

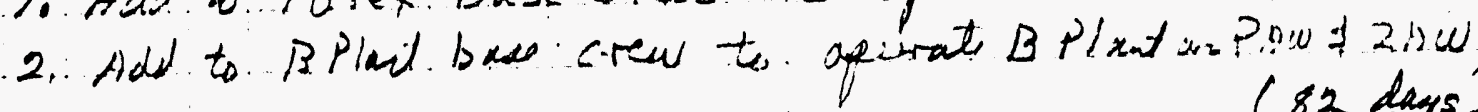
(82 days)

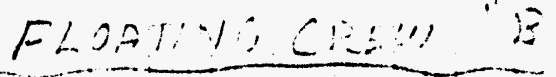

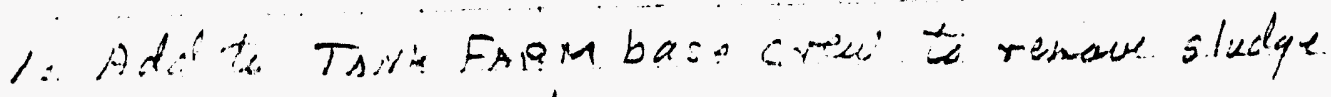
and do Jelu wat?

2. Add to B Plat chew te praxisys PAs

Approxinnich 232 dap / y eas auailuble ou 4 cas from whili it select for PAS proceidy

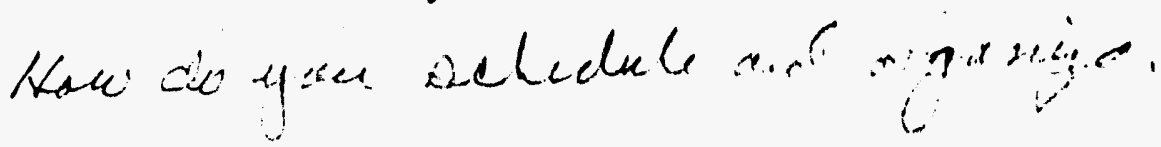
UNCRASSIFIED

$$
2-4-60
$$




\section{UNCLAsSIFI $=0$}

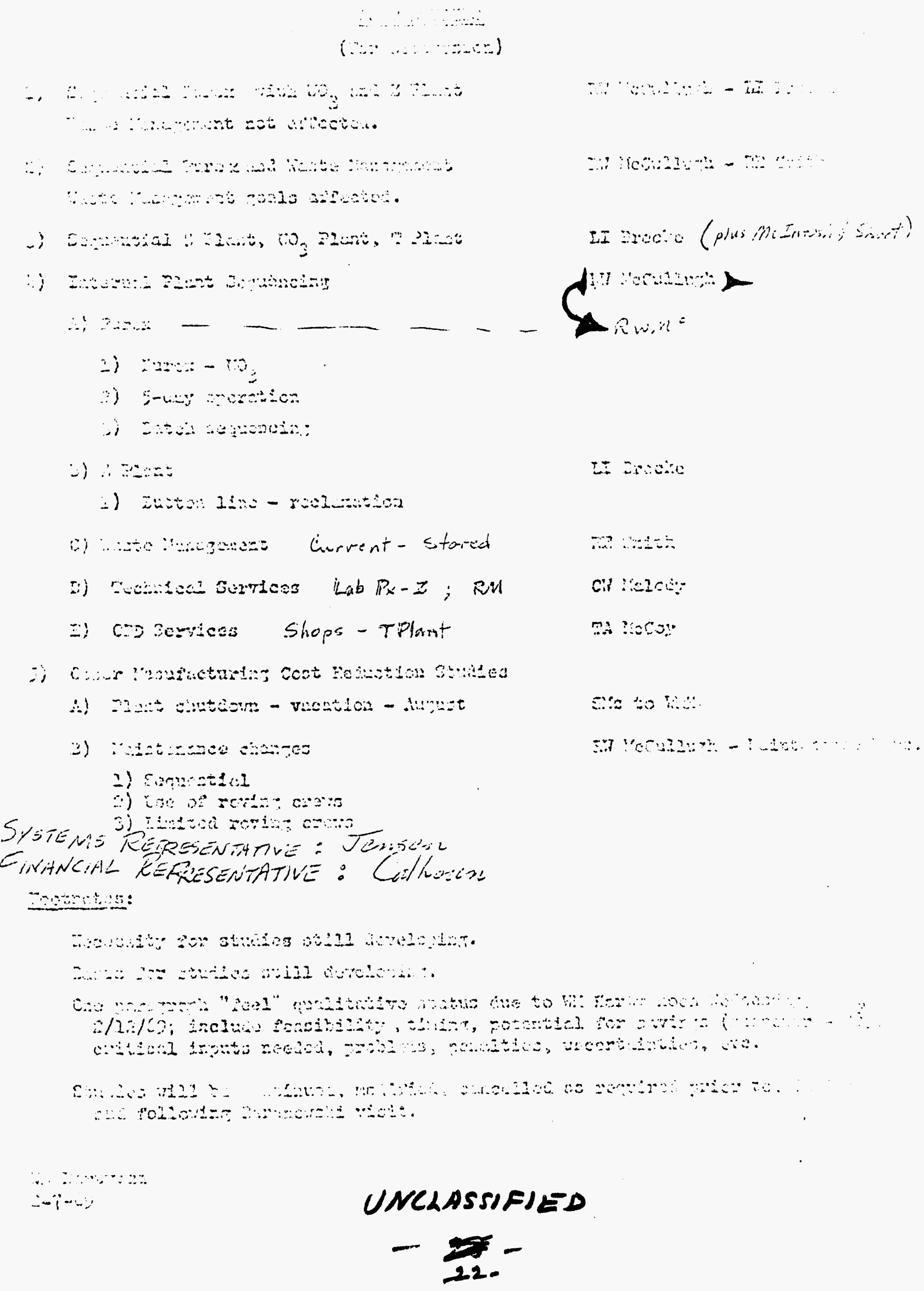




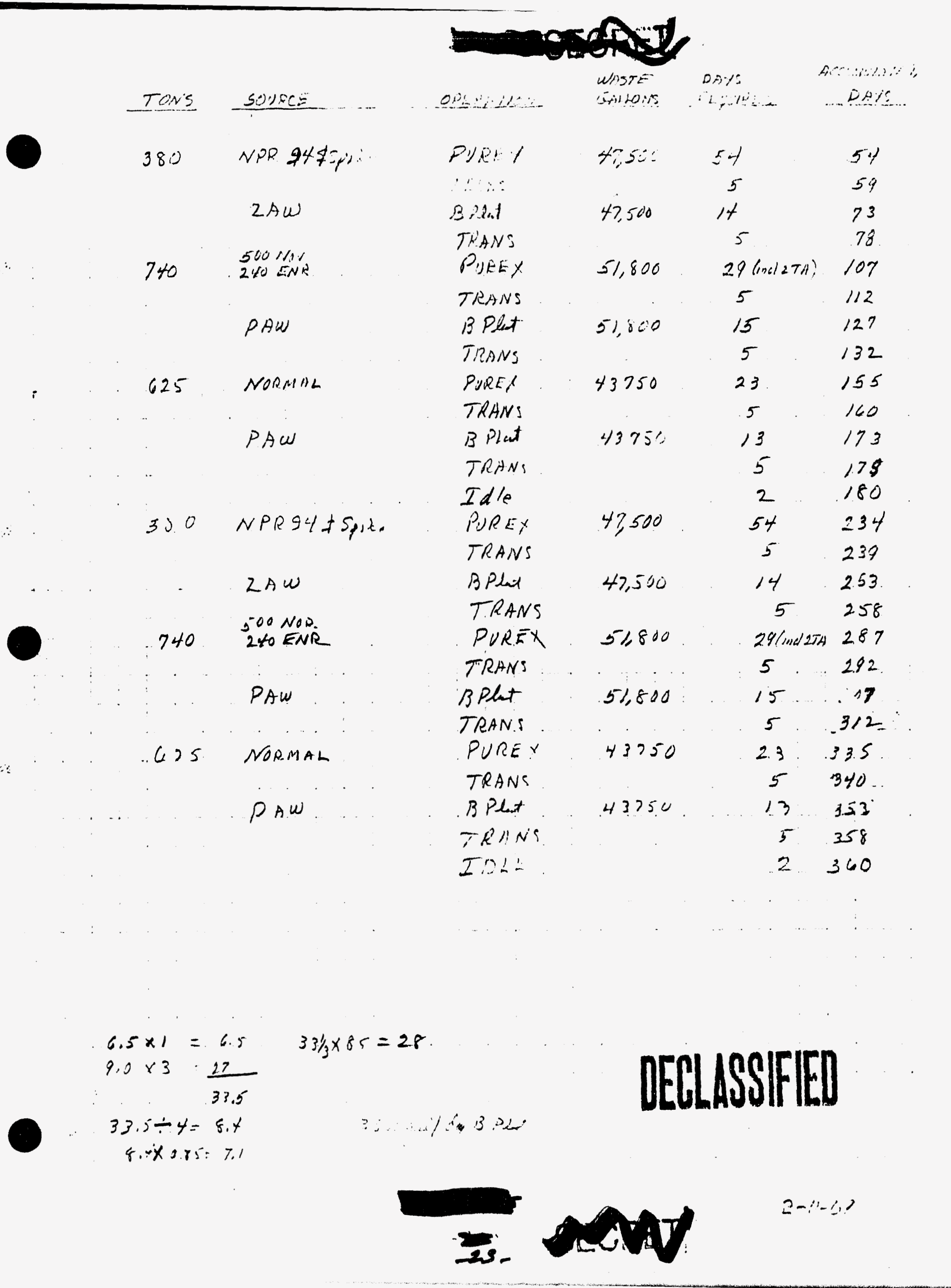



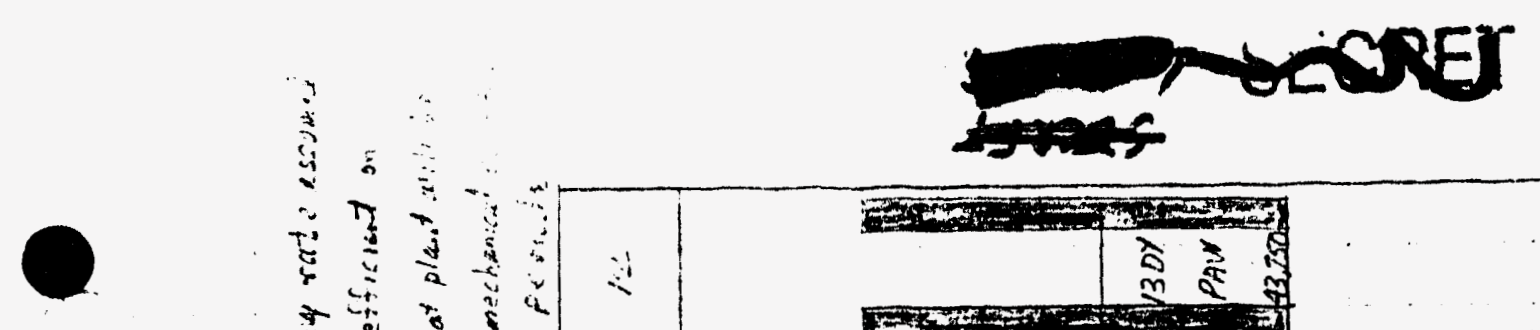

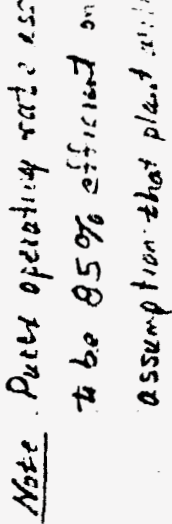
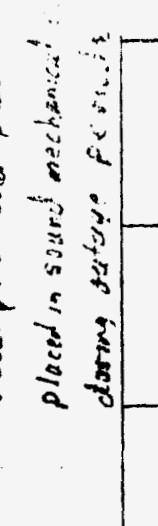

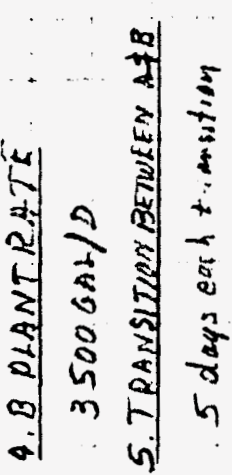

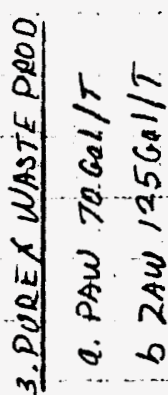

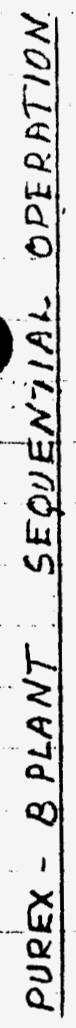
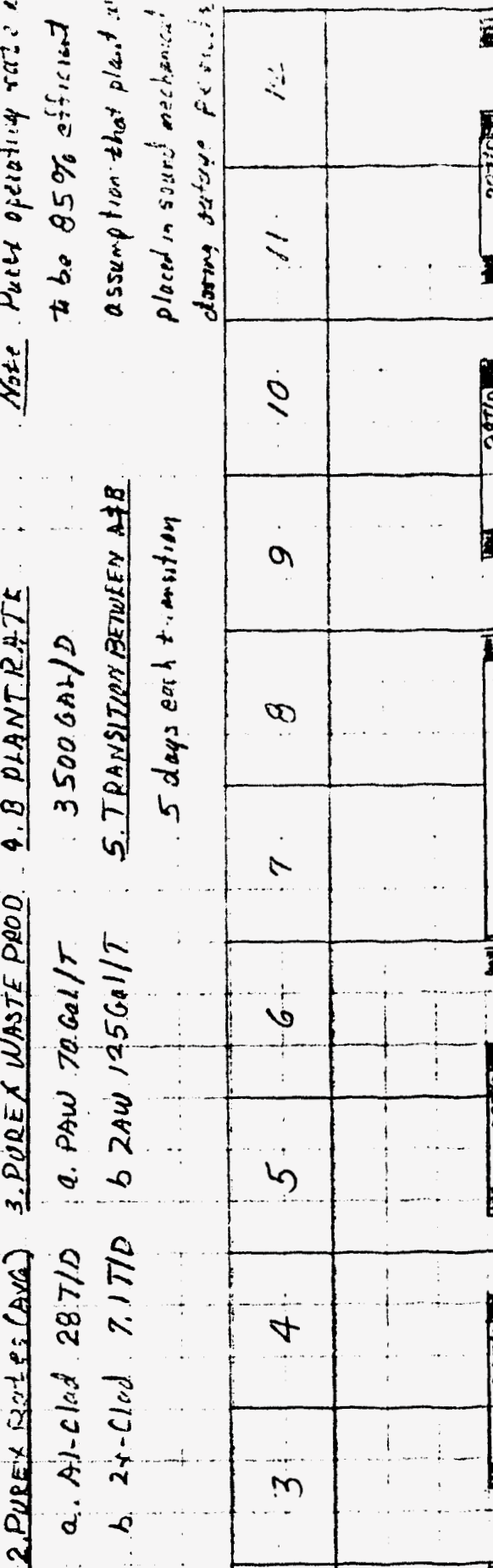

$\Rightarrow \quad$ -

然

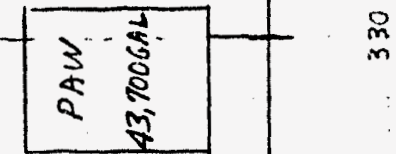
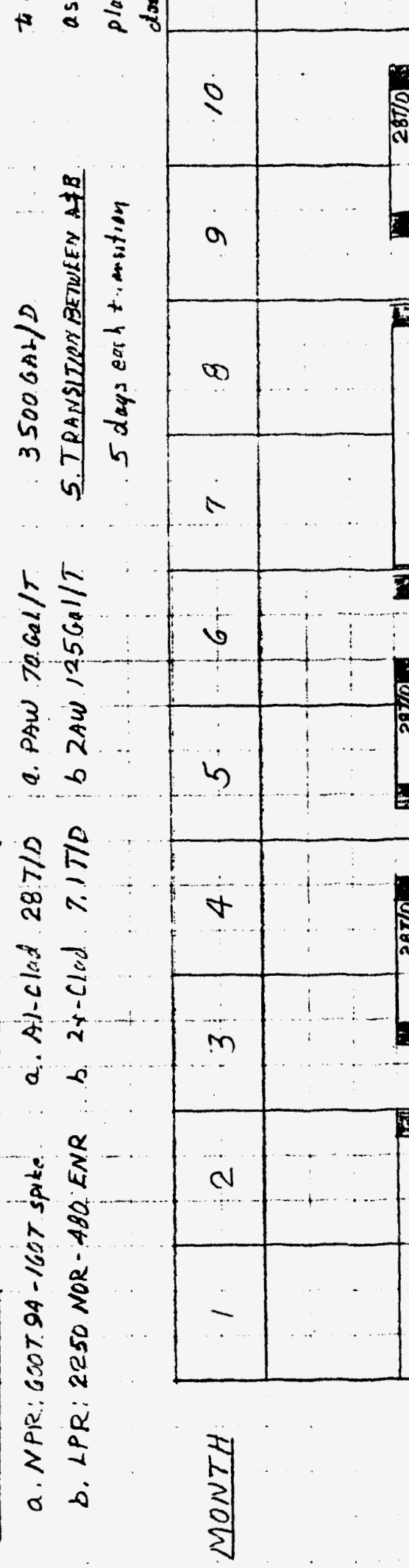

ปิ

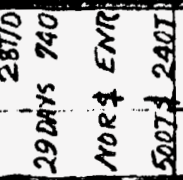

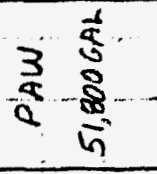

$a$

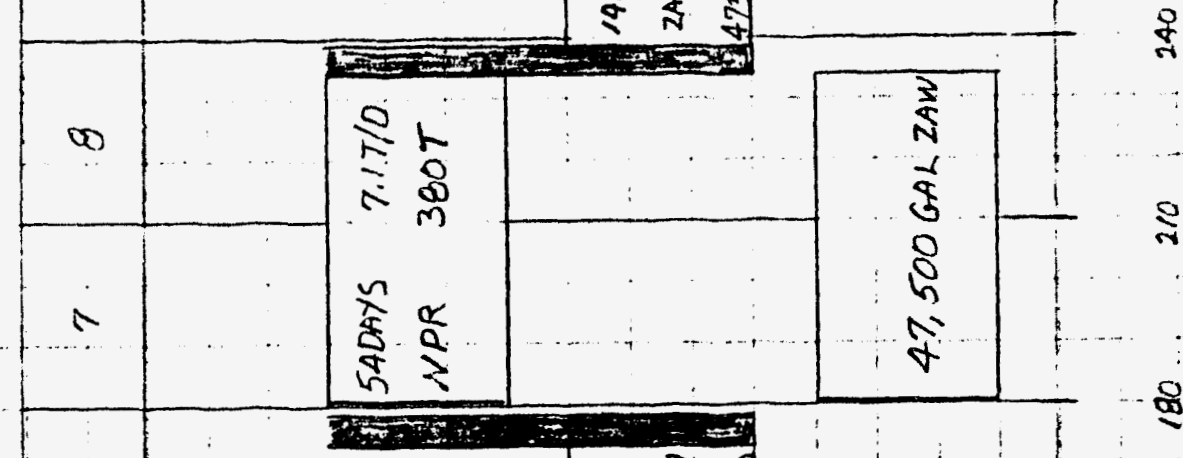

1 1 พูญ

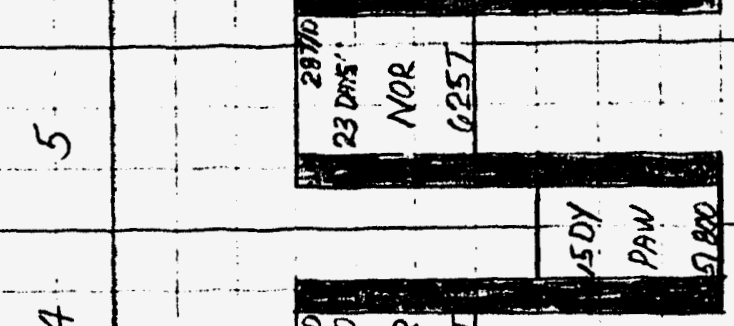

บิ

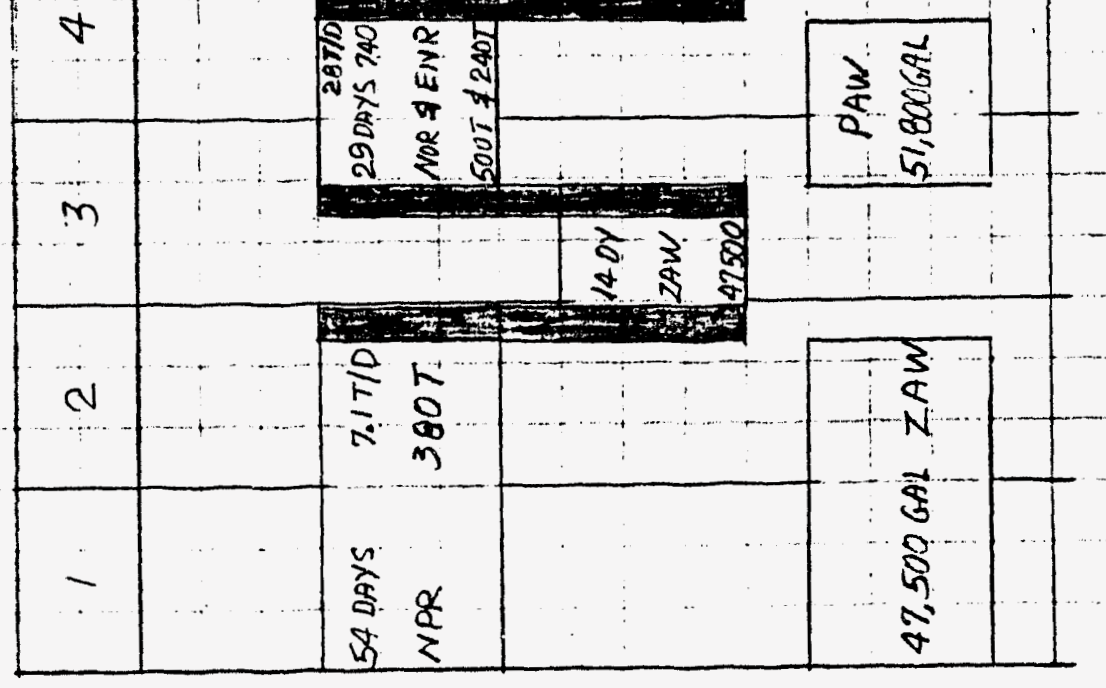

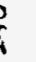

$\frac{4}{9}$

원

ริ

3

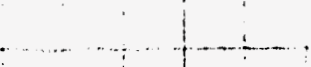

. 


\section{$-5$

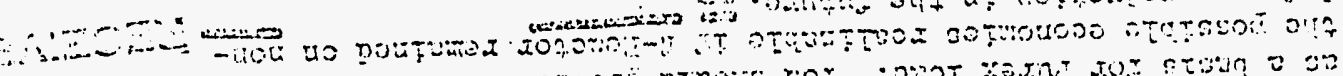

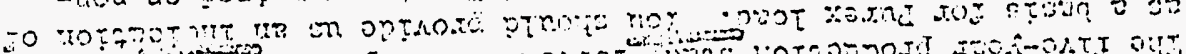

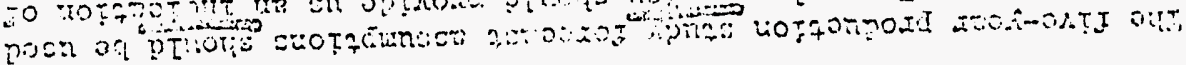

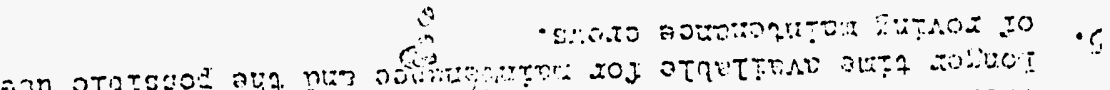

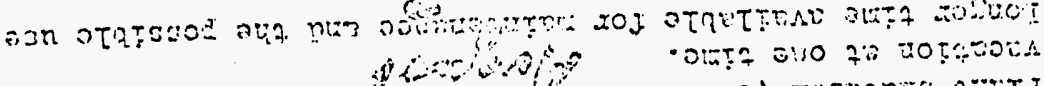
อ)

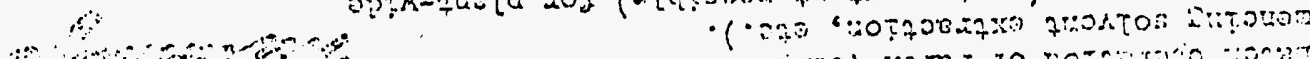

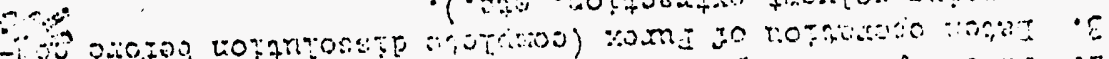
$\therefore$

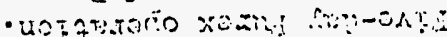

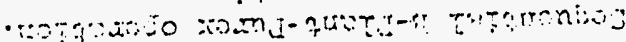

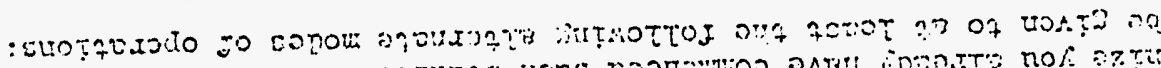

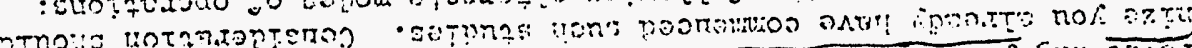

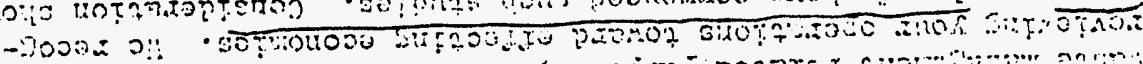

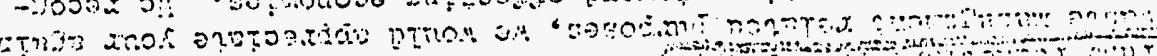

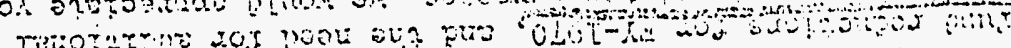

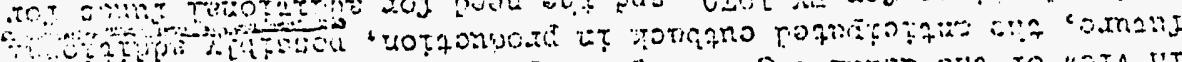

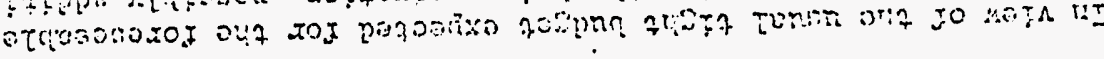

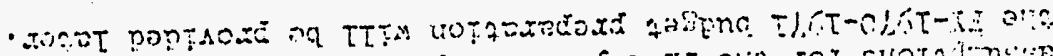

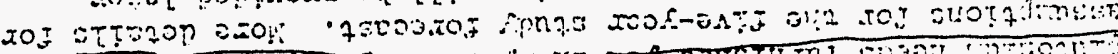

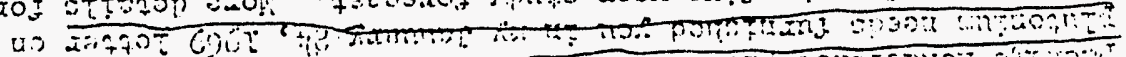

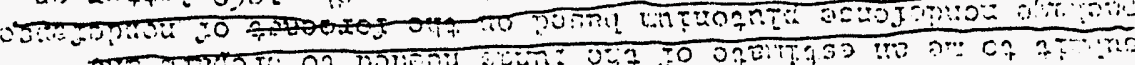

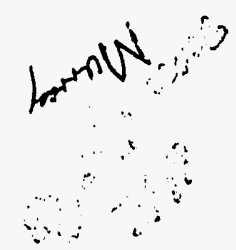
10

1

\section{$\therefore つ \Xi 己$}

no:

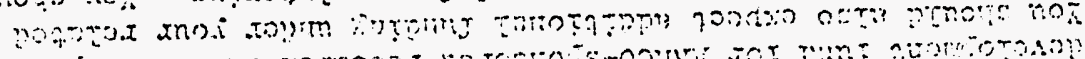

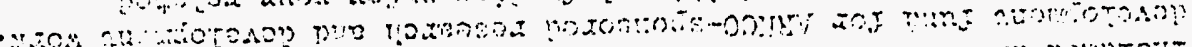

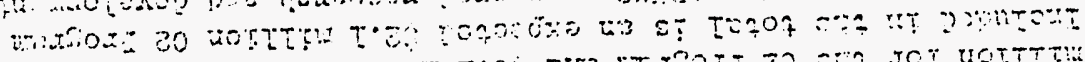

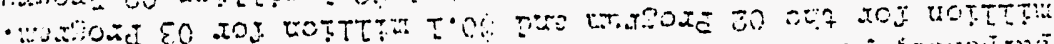

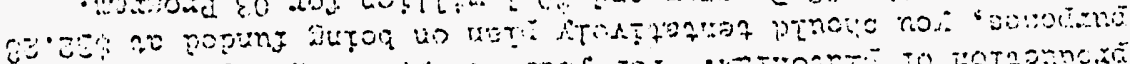

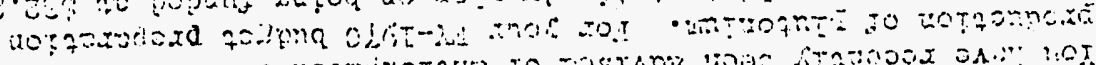
W. W :

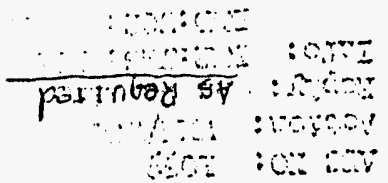

$$
y=i f 0
$$

$\longrightarrow \rightarrow \cdots+x$

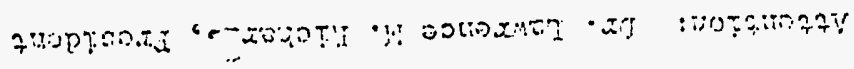

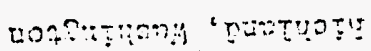

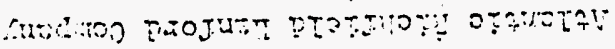

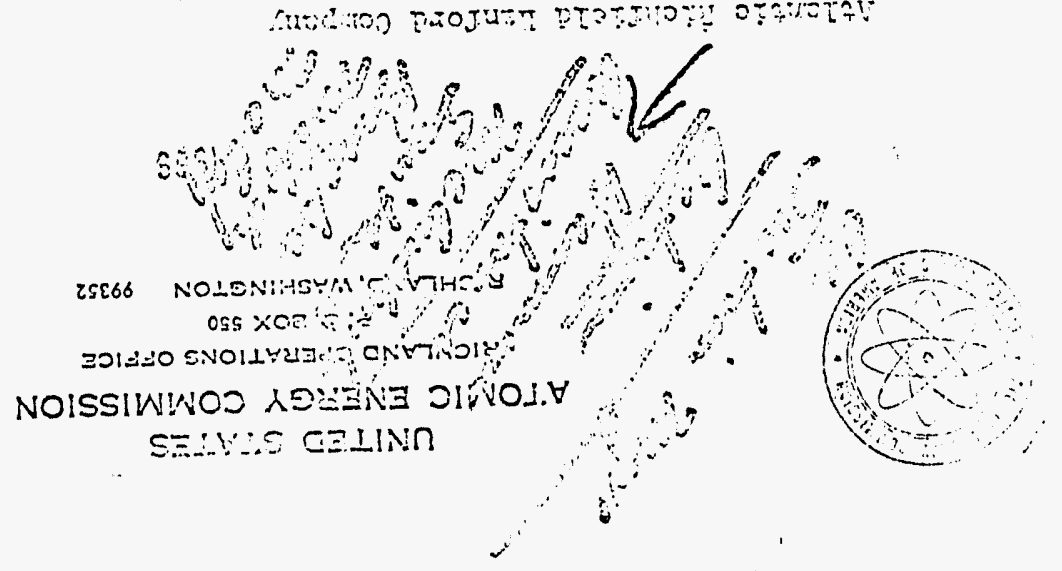


Dr. I. ก. R1claràs

ALISCO

$-2$

JAN 301958

You silowid coraider the expect of extending the solidification

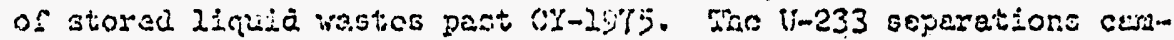

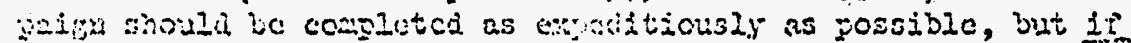

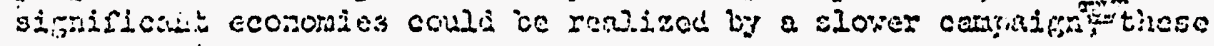
siould be jointod cht.

Informetion nceded is the feasibility of the various modes of

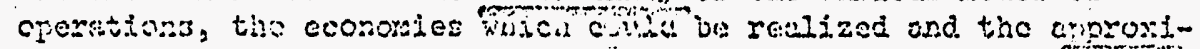

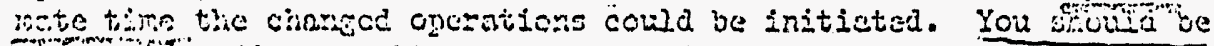

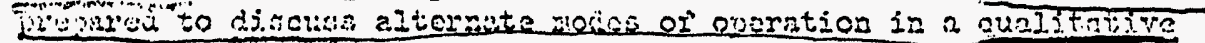

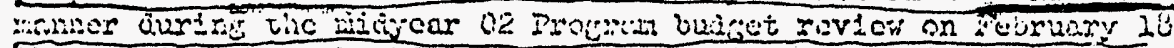

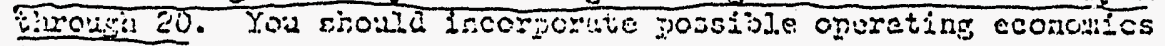

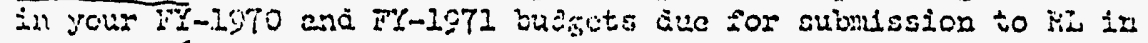
A

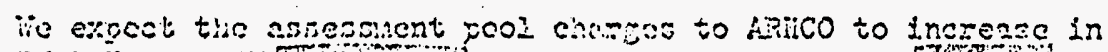

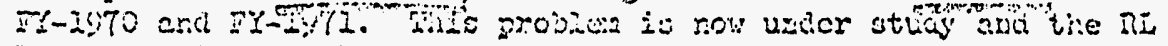

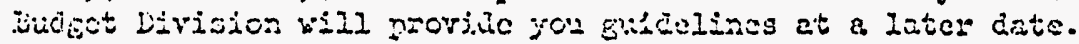

I rial be Elad to discuis these menters bith you at any tive.

Very truly yours,

ORITNAL SIGNED BX

O. J. ELGERT

o. J. Engres, Director

D:CNI Ciletuleal Processine Division (Contrest Aunfasistostor) 
March 13,1970

Bx

To MK Housman

Foin VR Chapman

DECLASSIFIED

Sequential Operation

Attached are ') DMCD's forecast of the forecast; 2) th plant load in a sequential mode imposed by the forecast; 3) the plat load if only $75 \%$ of the forecast is processed; and 4) a chart which models operations if inly $75 \%$ of the loud is processed. This will be used this afternoon as the committee discusses the model and the socendmex of rates assumed.

You will note that

10 $\mathrm{UOH}_{3}$ pleat is added

RECEIVED

2. The way the $234-5$ batten hin well probably fit. in 15 added - This about convinces me that a Durex - Butte In sequence will not fit. (A it hel day rato was assumed 3. All the 94 fuel produced by KE reactor is processed in a single campaign each yea. Thus we will be Slaving $644 \mathrm{t}$ verna. and 143 tons NPR fuel excess each year.

4. By using the single. KE 94 campaign, we dent develop ending h time $t$ accermelate a sixth full PAS rum; however the 19 th ruse occurring in the first hal y FY 1925 cleans up what is theveticall left.

This is a test only since. I don't have writtenin-blaod commitments on some of the plant ats

$-27-A D^{2}$ 
Tyolsabyear

$$
\begin{aligned}
& N \text { Reartor Q 6I: TOE - 8.8\% Pu.280 } \\
& \text { KF Reactore 75\% TOE - 3.9\% Pu.210 } \\
& \text { Nor H1.Cled } \frac{U}{2185 T} \quad \frac{P_{L}}{801 \mathrm{tg}} \\
& \text { S4 Alclud 416 T } 175 \mathrm{~kg} \\
& 94 \mathrm{zr} \text {-Clad } 573 \mathrm{~T} \quad 7+5 \mathrm{~kg} \\
& \left(\begin{array}{lll}
K E & 04 & 421 \mathrm{~g} / \mathrm{t} \\
K E & \text { NOR } & 36606 \mathrm{~g} / \mathrm{t}
\end{array}\right)
\end{aligned}
$$

EHE PLANT LOND FPOM THE A DOVE FOPECAST

3

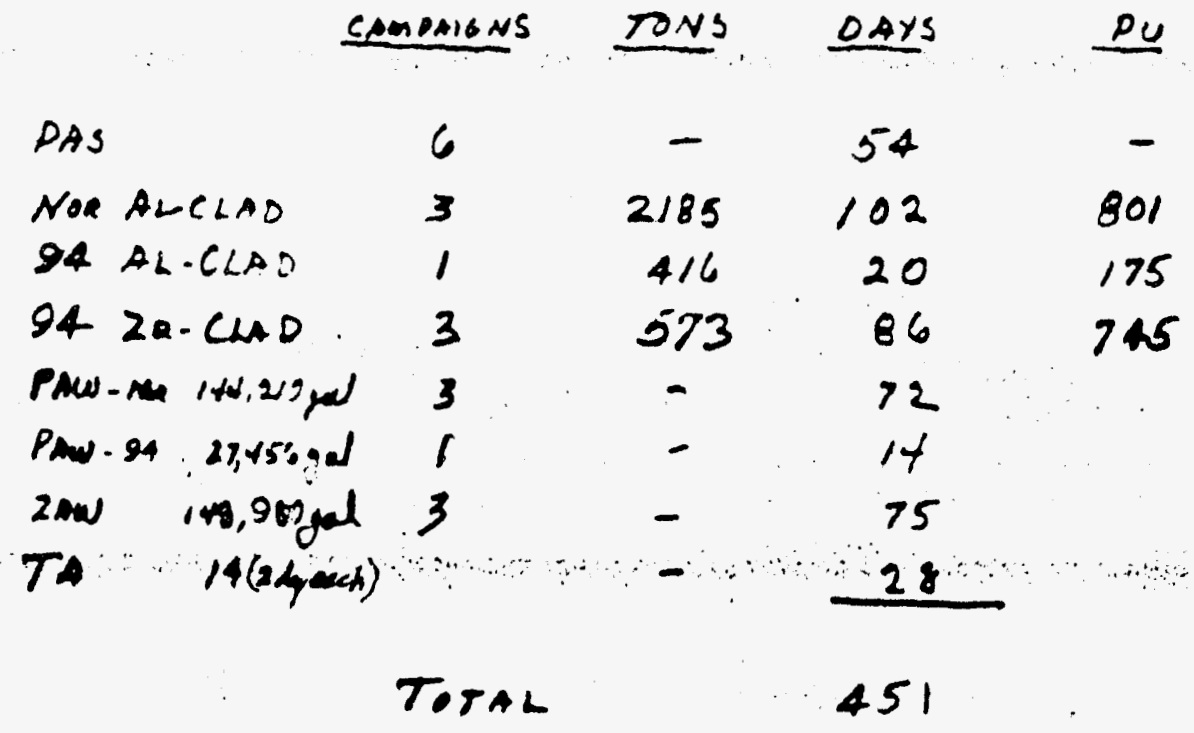




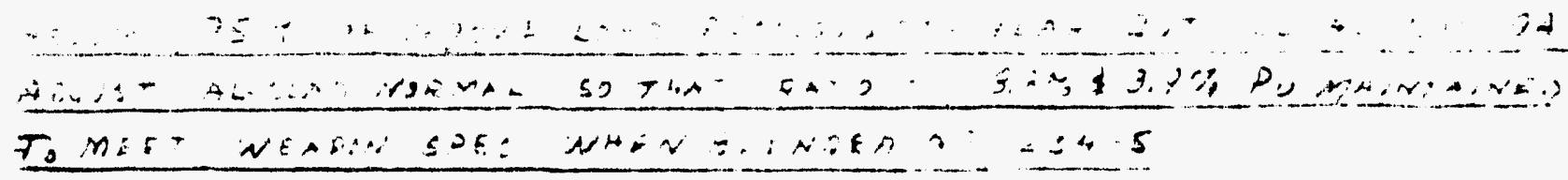

CAMPAIES
PAS TONS DAYS




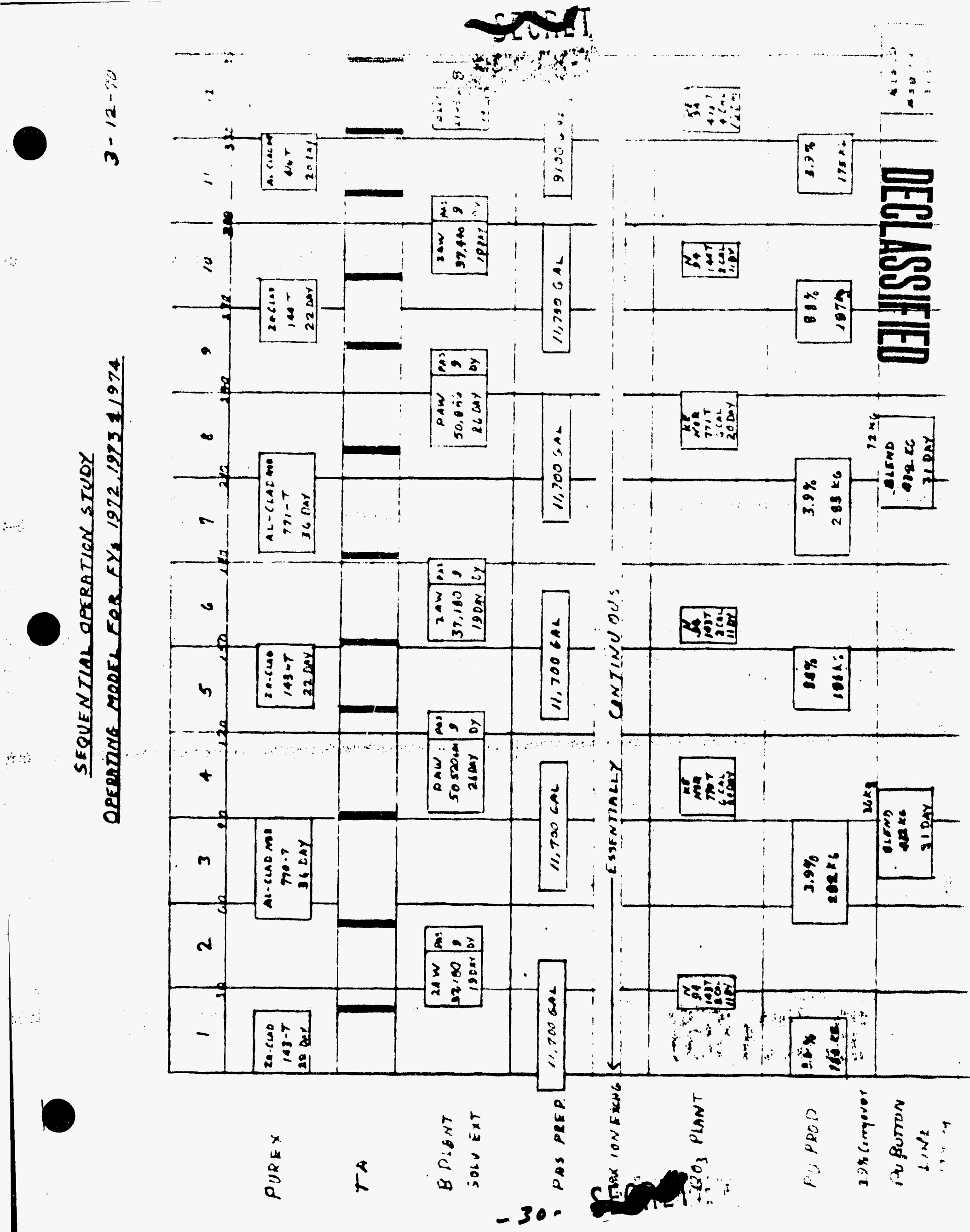



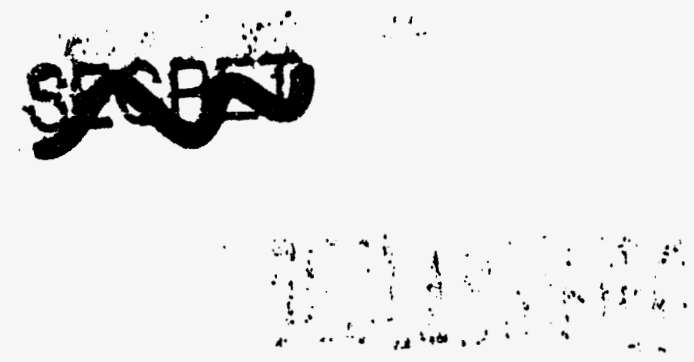

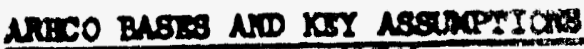

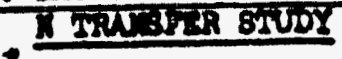

- NU DUl mector decnerger to bo processed in Purax

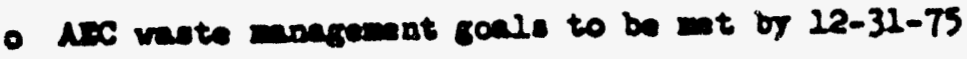

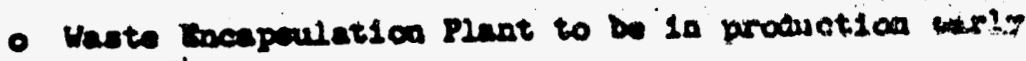
× 1974

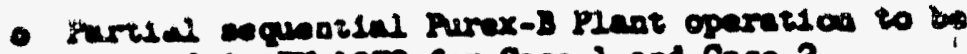
atrarted in II 1972 for Ces 1 and Caee 2

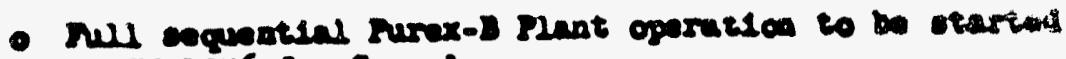
1. If 1976 sor the 1

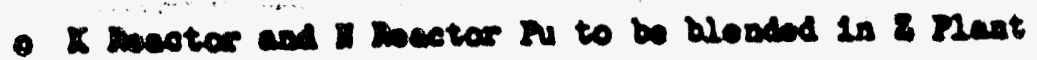

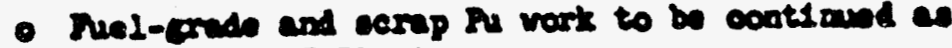
requered et 2 plant

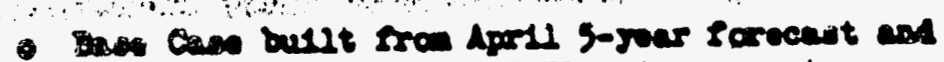

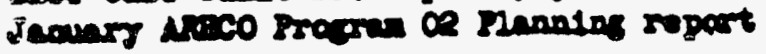




\section{DECLSSSFIED}

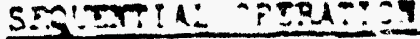

\section{Asstamions}

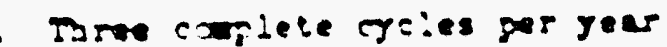

- Purex proceso capal os lidedted by

- CAH trosess capecley

- Uay storace copactid

- Arerase processlos ratos

- M-cias rued la Pirex

- Ir-ciod runi la purex

- cal da Binat

- PAs la D plear

- Pu button Uoe

- $\omega_{3}$ Plave
$\$ 9.000 \mathrm{gat}$

Soc ry

$23.6 \div 110$

$6.7 \pi /$ Sav

2,000 ond and

$2,600 \mathrm{cos} / \mathrm{das}$

17 rider

wo rsider

NI inalleble N-cled gl uraslon procesed

eceb year la ase Purax cepesos

- Lotlented bullepp basla lavestors

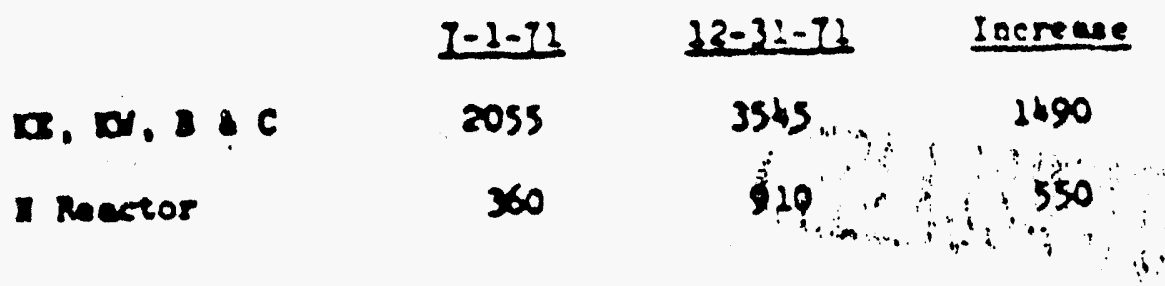

$x$ 
1
$1 \cdots$
$i$
3

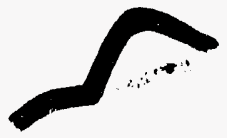

dit

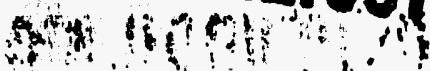

[3]1115S57730

a

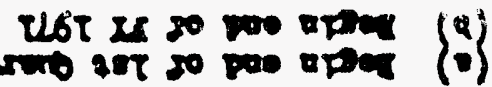

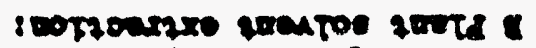

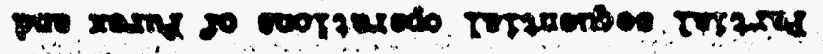

\begin{tabular}{|c|c|c|c|c|c|c|}
\hline - & - & $\infty$ & - & ongt & $\cos s$ & $916 \mathrm{t}$ \\
\hline - & sti & $\infty$ & - & ssse & 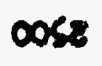 & $S 16 T$ \\
\hline $5 \%$ & Sw. & $\infty$ & - & sfor & $\cos 8$ & N16T \\
\hline $\sin$ & $\sin$ & $\infty$ & - & $\operatorname{sen}$ & 0658 & ELST \\
\hline $\operatorname{sog}{ }^{\circ}$ & STP & STES & fort & $\infty$ & 6506 & $\because E$ \\
\hline 5 & sit: & se & $\cos \pi$ & $\cos \theta$ & $\operatorname{sog} \pi$ & $12 \alpha$ \\
\hline & $(\sqrt{\pi}$ & $\operatorname{mo}$ & $( a ) \longdiv { Z }$ & $(\nabla) T_{0}$ & काजs & Do \\
\hline
\end{tabular}




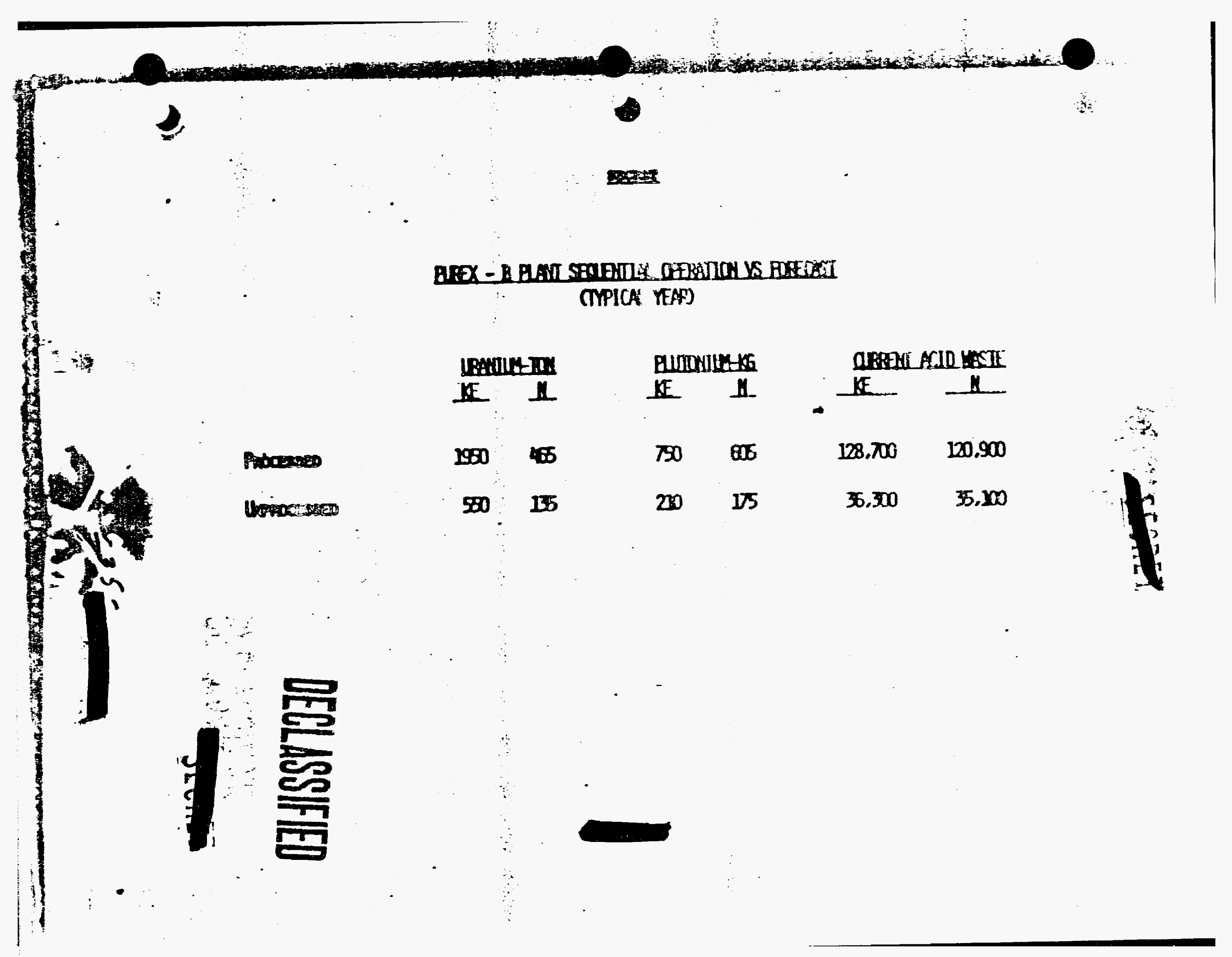




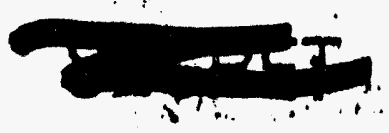

8

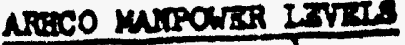

ereregos

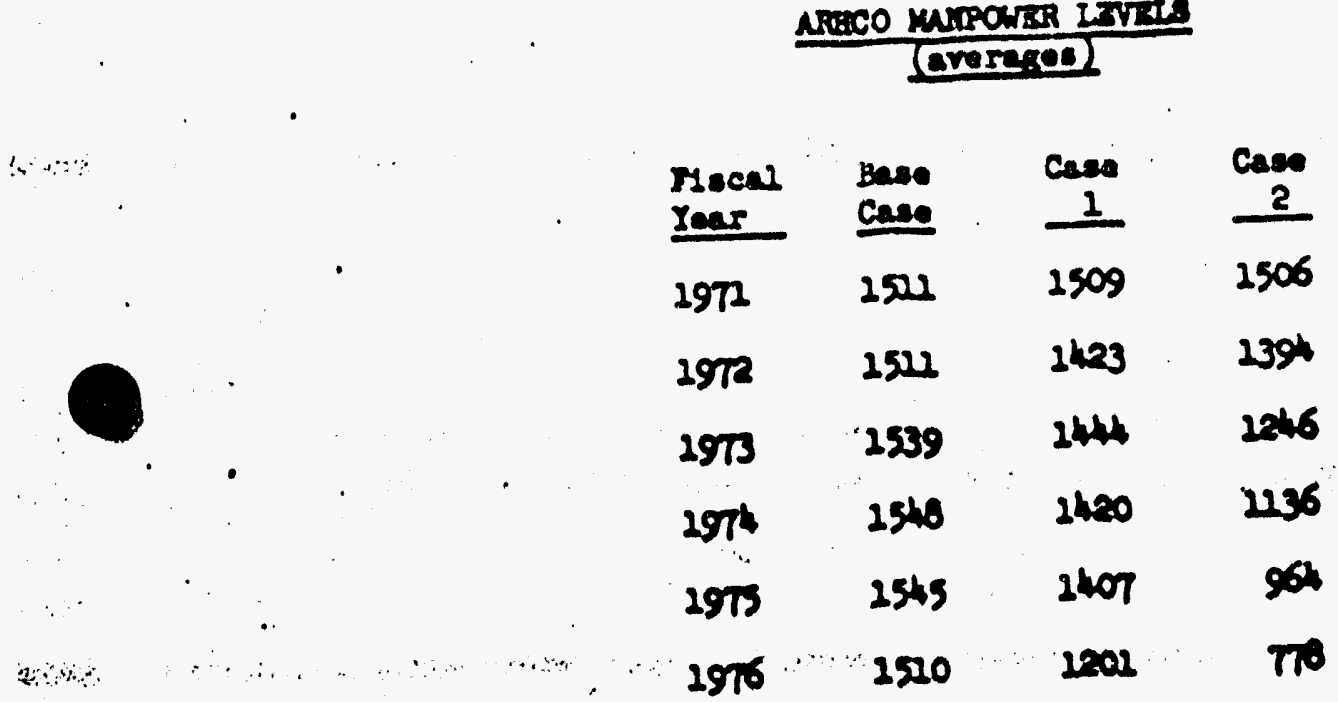




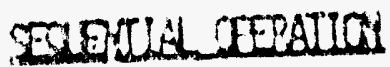

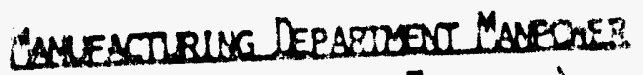

(PP Excepsuntion Exouced)

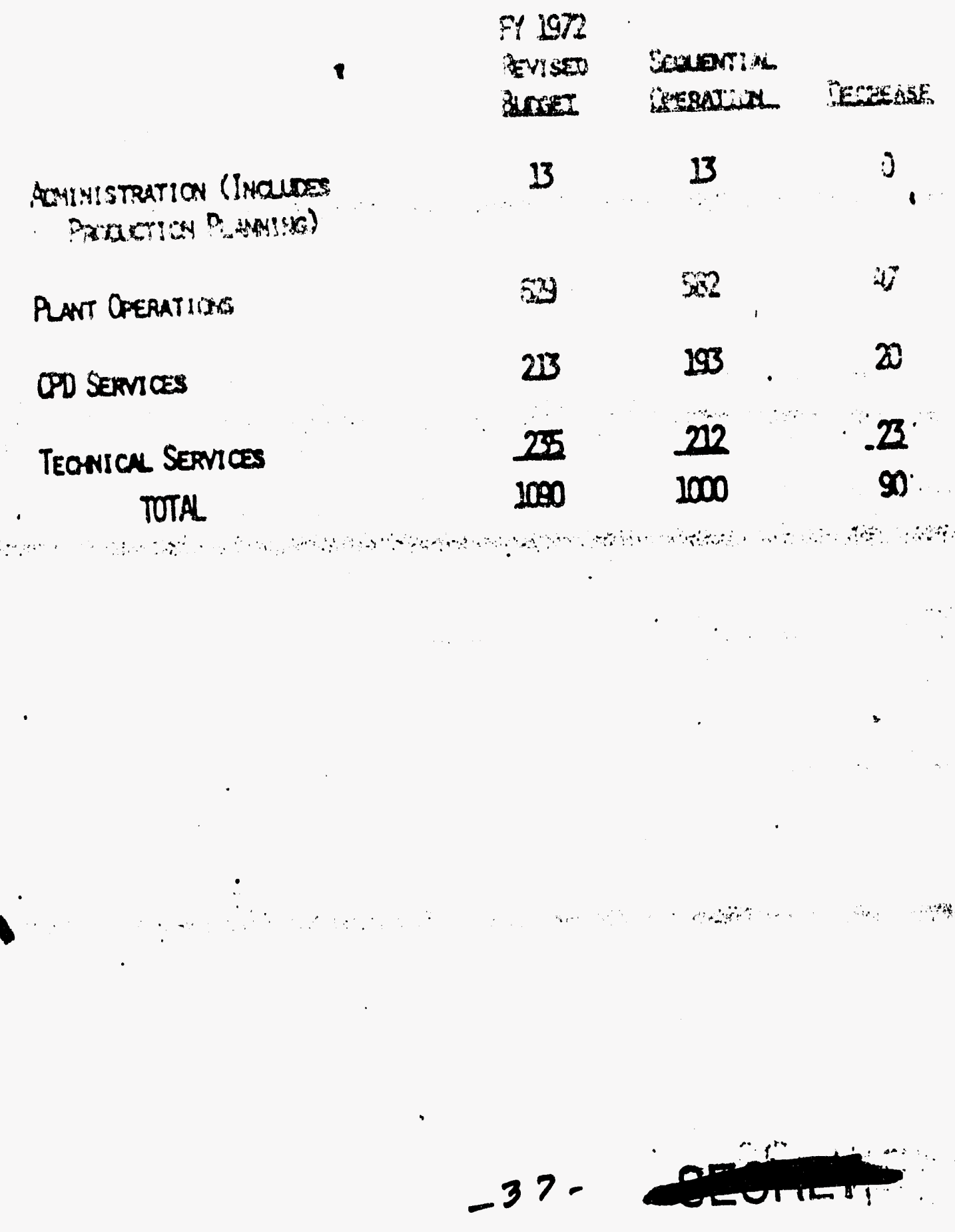


GERUATTIAL OPSRATICA

Manufacturlas Department Cost Roduction

(IP Encaponulation 8xcludud)

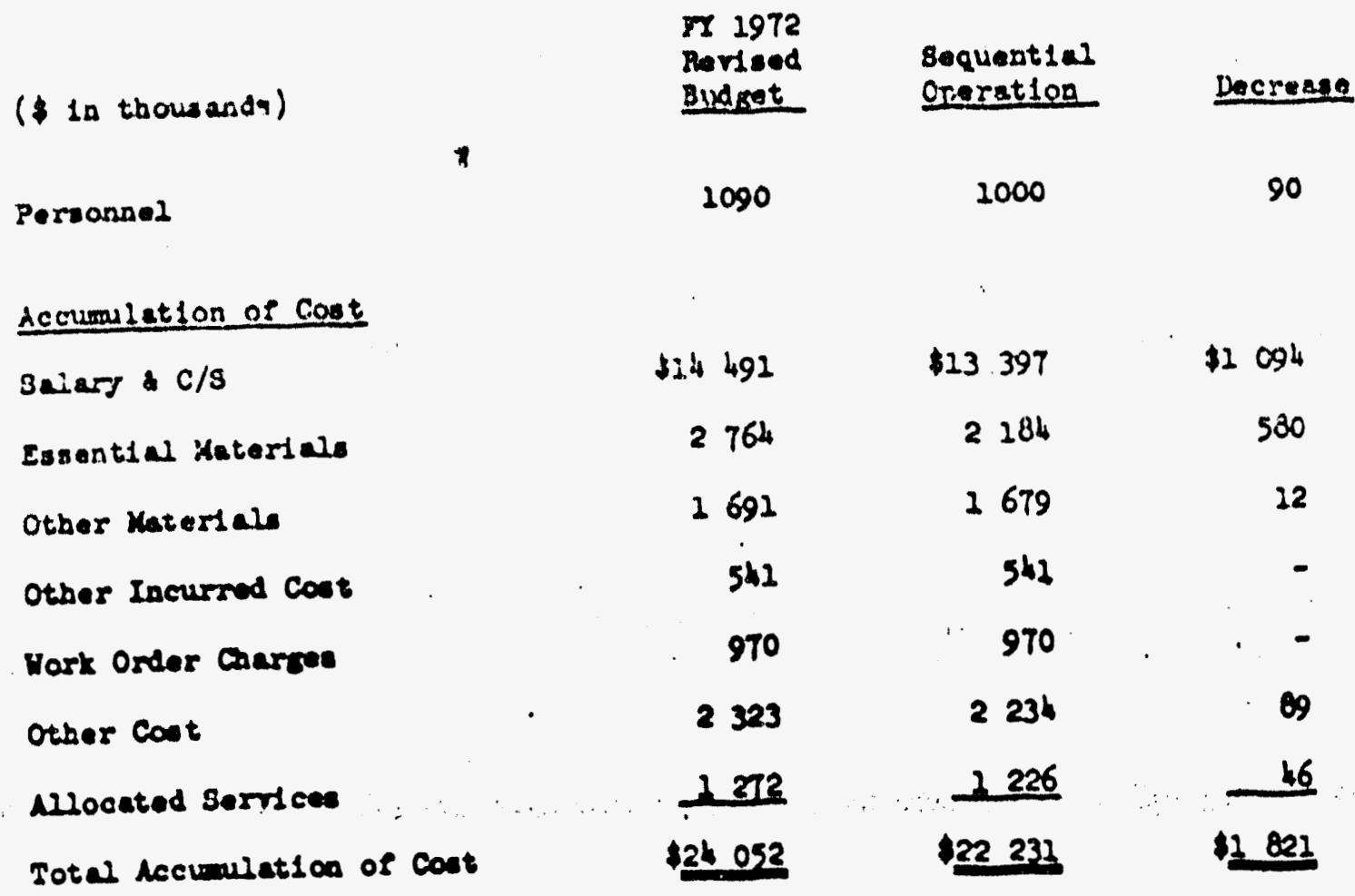

Diatribution of Cont

02 Product 100

122328

$\$ 20507$

11822

Other Accounts

$12 h$

124

-

rotel DAstribution of cost

$\$ 24052$

222231

Q21
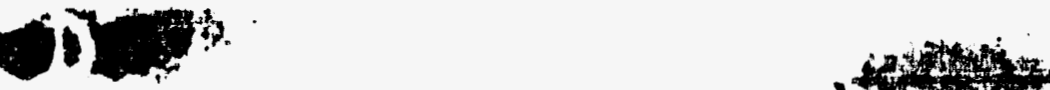

Axtats 


$$
2 \pi-8
$$

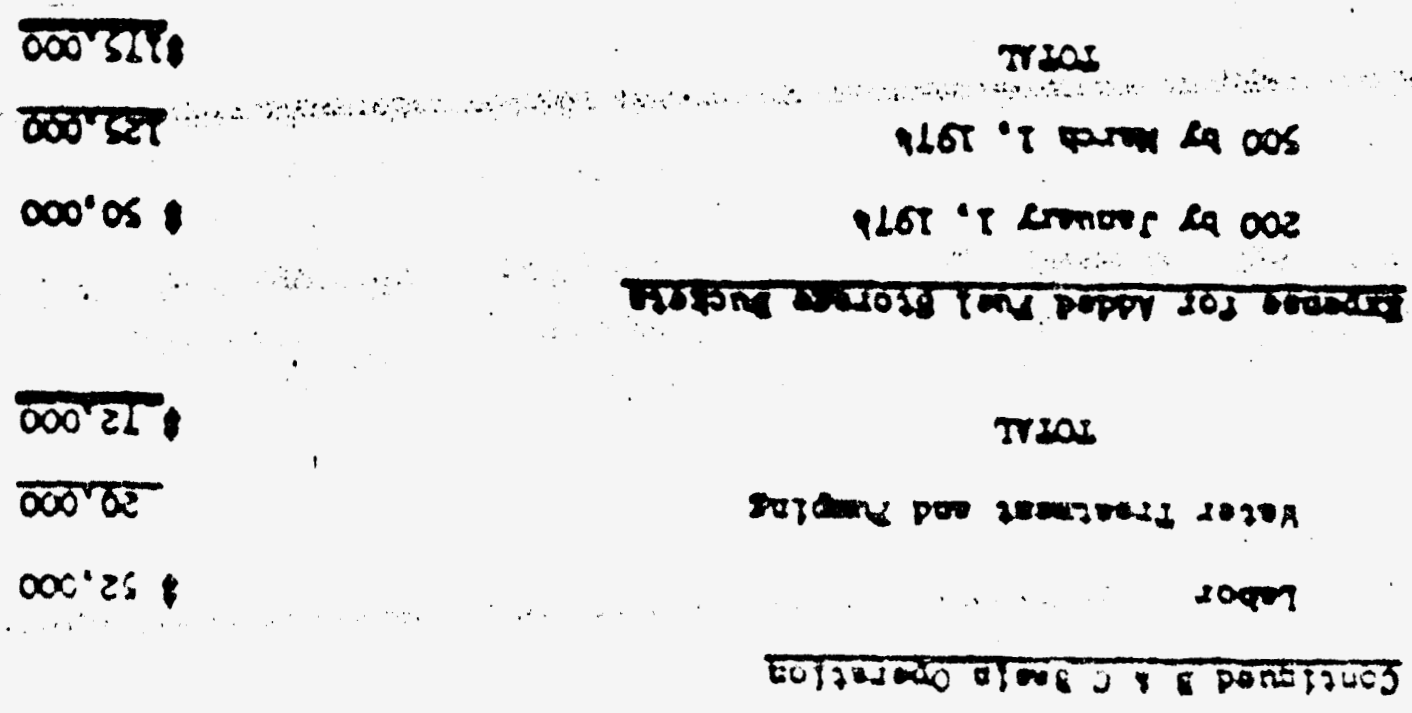

Fิnस

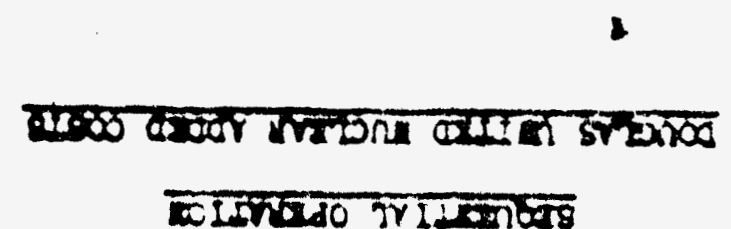

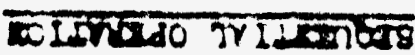




$$
\text { SEQUDF }
$$

Px

5600

$N 6=0=2150$

ki $\frac{4-200}{6350}$

$K K Q=\% 4200$

$\therefore \Leftrightarrow 6 \% 3400$

$$
\begin{aligned}
& N(8 \% 660 \% 2380 \\
& N E \sim 4.5 \% \frac{2300}{4680} \quad 360 \% / 4680=77 \%(85 \%)
\end{aligned}
$$

$$
\begin{aligned}
& N^{\prime} 4 \% 580=2080 \\
& K \Leftrightarrow \sim 3.8 \% \frac{2700}{4840} \quad 3600 / 45 \%=14 \%(83 \%)
\end{aligned}
$$

$$
\begin{aligned}
& * N 69 \% 600 \approx 2150 \quad 3600 / 3850=93 \%(104 \%) \\
& K \Leftrightarrow 6 \% 1700 \quad \frac{3850}{30}
\end{aligned}
$$

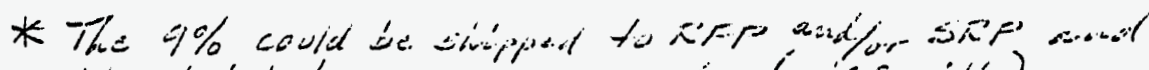

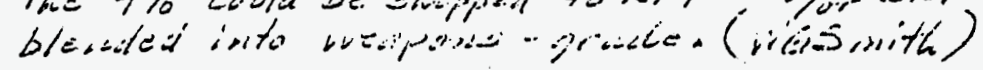

* * N $N 18 \% 225 \div 800$

K⿺ 6\% \%

(Segisch aud

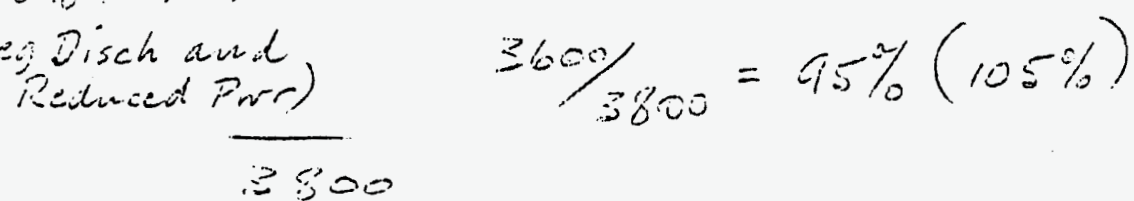

$$
\begin{aligned}
& 3000 / 4200=86 \%(15 \%) \\
& 3000 / 3+00=106 \%(117 \%)
\end{aligned}
$$

$$
\frac{300 / 650}{6350}=57 \%(63 \%)
$$

DECLISSIFIED 
$\longrightarrow$

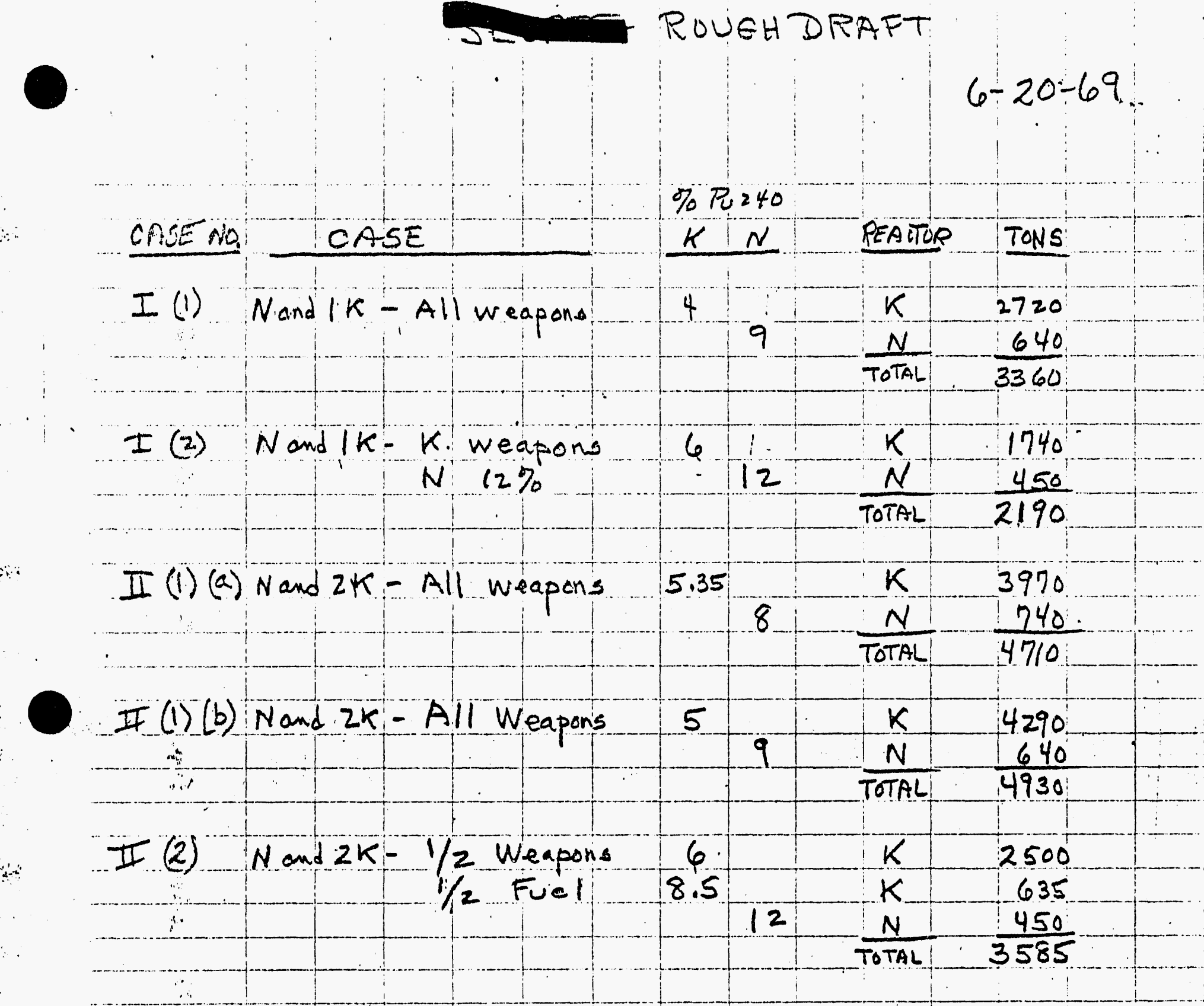

- Equilibrium year - E metal used at $k$ reactors and spike $(1,25)$ at $N$ rector for standard enrichment. 
PUREX - B PLANT SLIENTIAL OPERATION

WEAPONS GRADE PU FROM N AND ONE K BLEND

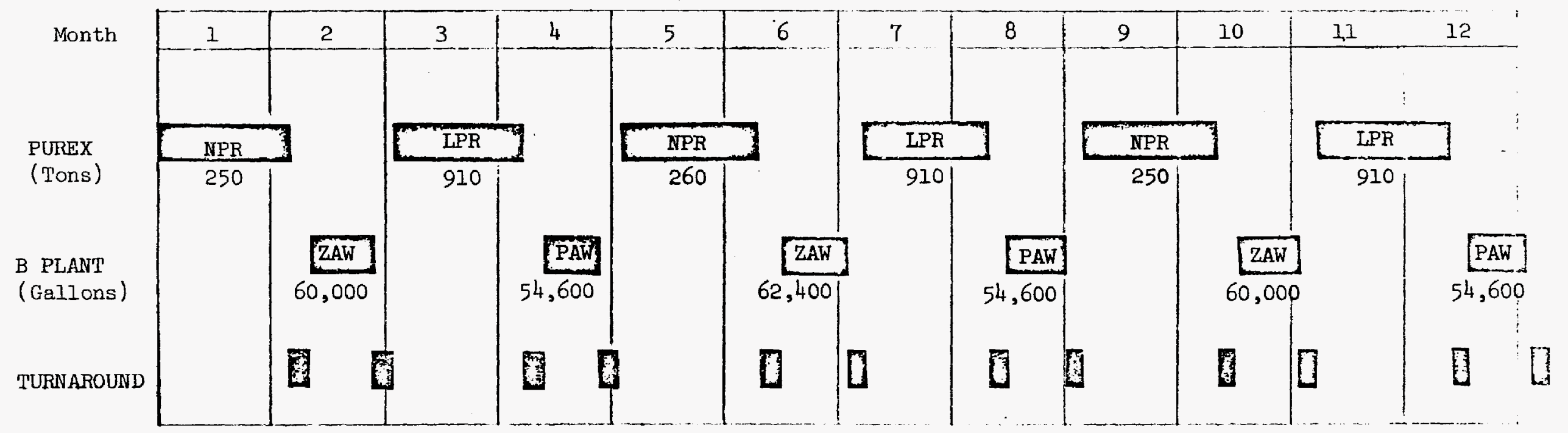

is

N REACTOR NONDEFENSE PU - ONE K REACTOR WEAPONS PU

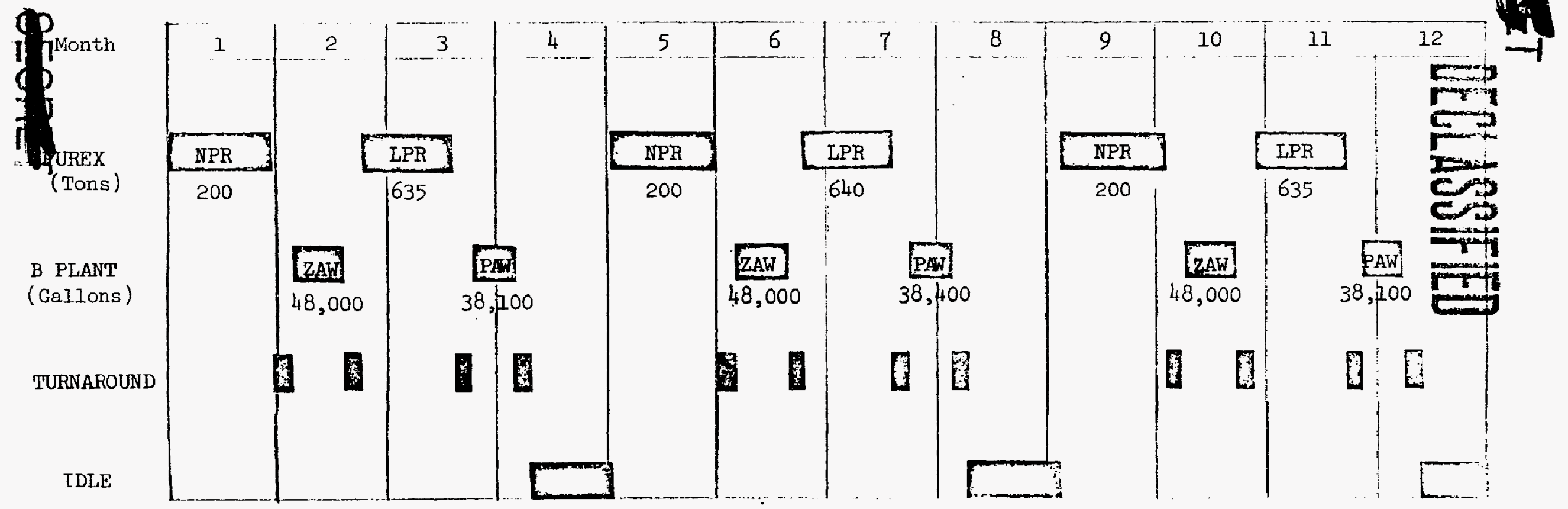




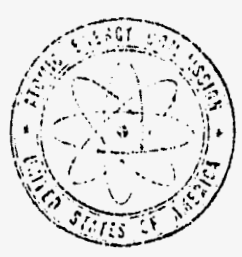

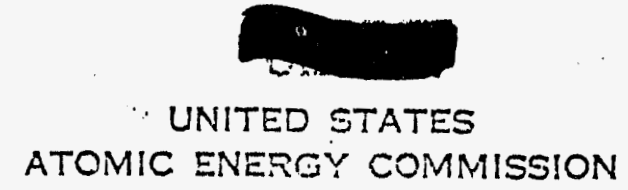

RICHLAND OFERATIONS OFFICE

$$
\text { P. O. BOX } 550
$$

RICHLAND, WASHINGTON 99352

\section{SEP 111969}

Atlantic Richfield Hanford Company Richland, Weshington
AEC NO: 1175

Action: WH/BND

Signature: RPC

Due : $9 / 26 / 69$

Info: $\mathrm{LR}$

$\mathrm{RPC}$

JWS

VCC

WCS

JHIS

ReP. Doc: DUN-615I

Attention: R. P. Corlew, Vice President, Oparations

Subject: SEGUENTIAL OPERATION OF PUREX AND WASTE MANAGMMENT

RECEIVED

Gentlemen:

SEP 111969

Teferences: 1. ARH-1302, "Quarterly Production Forecast, July 1, I969 Througin June 20, 1974," dated

R. P. CORI.FW July 28, 1969

2. DUSi-6151, "Availability of Reactor Basins for Long Term Irradiated Thuel Storase," dated August 13,1969 , by 0. C. Schroeder

Please suomit by September 30, 1969 a study of sequential operation of iaste Management and the Purex Plant Operations. The study should conclude the earliest date that sequential operations could start based upon the following assumptions:

1. (a) Reactor production scheduled in the July forecast (Ref. 1). Separations schedules modified to benerit sequential operation.

(b) The present Waste Manazerient Program schedules.

2. (a) Same as I (a) sbove.

(b) The Waste Hanagement schecules would be extended as necessary to optimize sequential operation.

3. (a) Reactor production reduction necessary to facilitate sequential operation. Any reduction should be required no sooner tilan FY-T1.

(b) The present Waste Manazement schedules.

Thes gropisted tron enelerusts, bastle

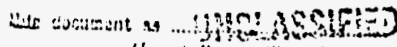

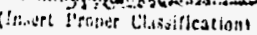

Document Iransmitlod herewis: contains RESTRICTED DATA.

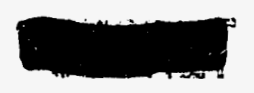




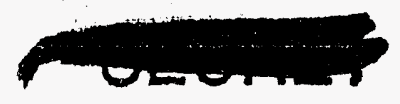

R. P. Corlew, ARIICO

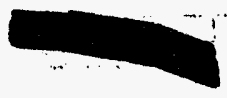

Please include. in each assumption that the U-233 separation scheiule wiIl be adrered to and that reactor basin storafe will be utilized to the extent of the besin capacities detemined by tre IUI stuly (Ref. 2), a copy or wich is attached. Consider the case for about one year's storase, utilizing tihe $K, B, C$, $D$, and it basins.

LC:JIC

Enciosure:

DUSi-6151, cy 31
Very truly yours,

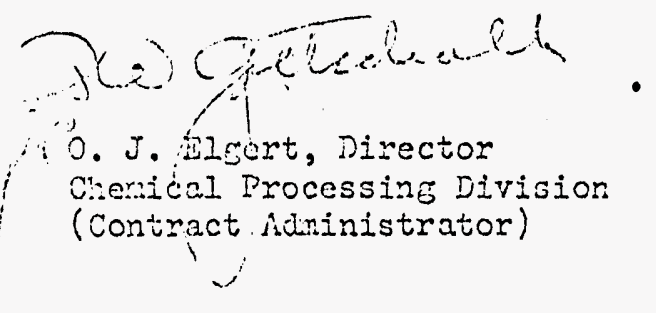




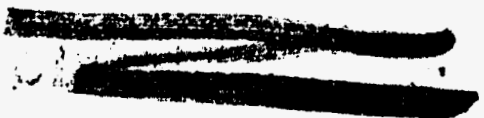

Date: September 15, 1969

To: D. McDonald

From:

V. R. Chapman

Subject:

SEQUENTIAL OPERATION

Meet1ng: September 14, 1969,6:00 p.m. to 8:00 p.m. in Federal Building.

Attended: M. K. Harmon, B. M. Dobbs, V. R. Chapman

\section{General}

The incremental cost savings will be examined for the various cases. To develop these costs and to time phase them, we w1Il have to determine when we start laying off, how many and the rate at which this will be accomplished. Also, the cost of separating people from the payroll.

Additfonal buckets for metal is a DUN cost. Although not discussed, I assume it is also DUN's responsiblilty to $\mathrm{flx}$ up basins to handie overflow from the $K$ reactors.

It is presently Harty's position that we cannot risk running thorlum with green operating crews.

Cabe I

Since the Th-U-233 schedule and the Waste Management goals for removal of stored waste are firm in this case, we cannot go sequential until the mining operation is completed. Howerer, it is belleved the following should be examined to defend against questions sure to arise.

1. What would happen 11 Purex ceased processing January 1, 1970 ?

- Basin inventory at start of thorlum run and at the end of the run.

- Erfect on Brecke's operation

- Effect on known request for fuel-grade Pu

- What would we do with the people held for the thorium run?

The saving would be mainly essential materials, steam, electric1ty. 
D. McDonald

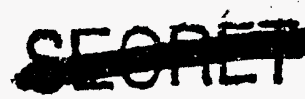

September 15, 1969

Page 2

2. What would be the effect of running at maximum possible rate until the start of the thorium run, bringing the basin inventories to the lowest possible level.

- Basin inventory at beginning and at the end of the thorfum run

- Iodine problems

- Pu storage problems

- UO 3 handling

(This would increase costs and out-of-pocket expenditures for FY 1970).

3. How much ahead of the start of sequential operations can Purex operation be stopped and the payroll reduced, assuming that in the interim period before sequencing advantage will be taken of the excess basin storage capacity. As part of this, the date when all basin capacity becomes full and DUN cut back has to be determined.

a. When do we train people for sequential operation?

b. When do besins become full and force DUN to cut back?

c. Any other problems.

VRC:mkI

cc: File 


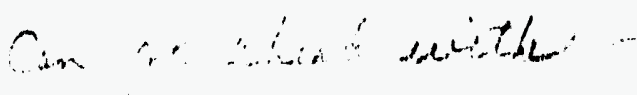

1. Assume 1-1-70 Perex sluxidianem

Basin Inv at stat of $T h$ ram

Basin ine of tod of The rea.

Dute basing cor fall

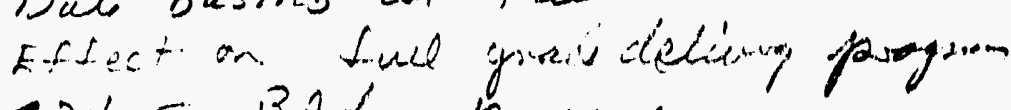

234.5 Bedy properam.

$\mathrm{UO}_{3}$ plawt pergen

cust defferited fal $\mathrm{FY}>0,71$

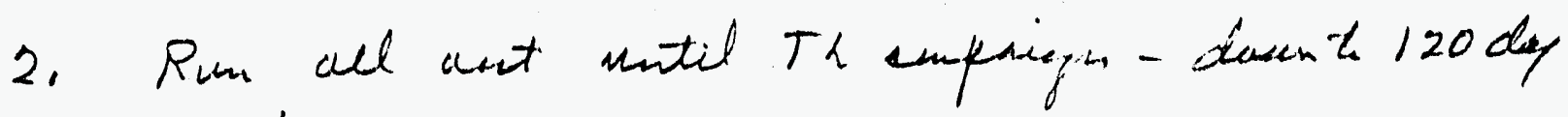
cruting.

Basin inv at sivel of Th rean

Basin inv at end of Th rem

Leacer Pevers diverial

Date basing cire fall

Effect m $234-5$ Bldy stirgyt

Cust chffurteral 70,71 , ile

actins ous cuet of 'eveline cutred

3. Asoure that un follas forceart and

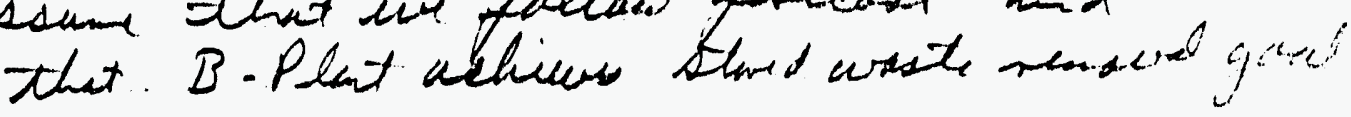

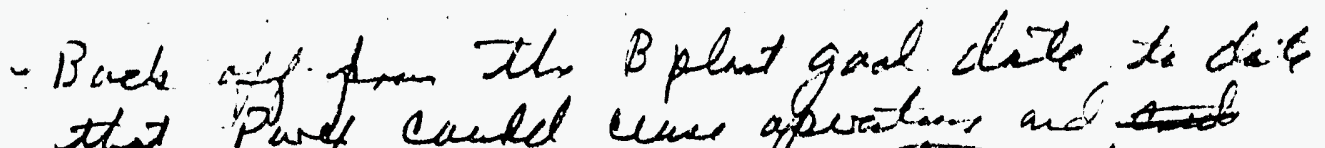

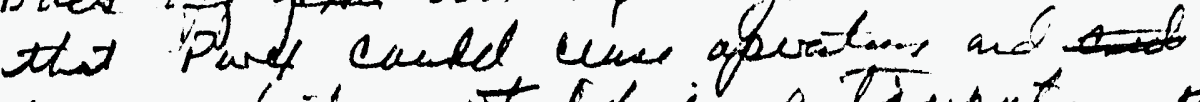

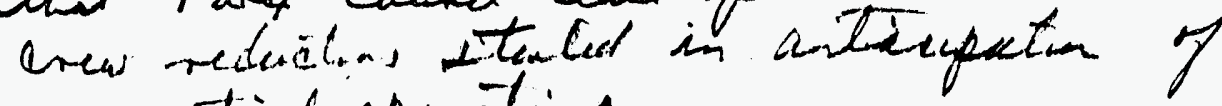
assumpton that hinimg wiet C..

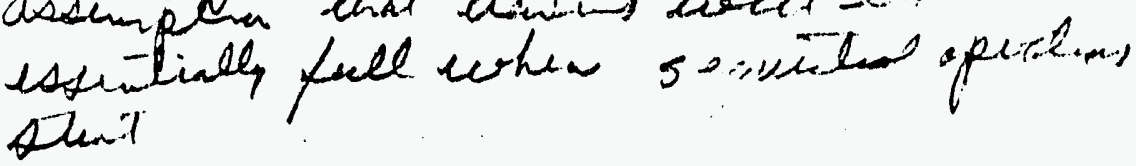

4. Ditimin the maximere had of $N$ revelar

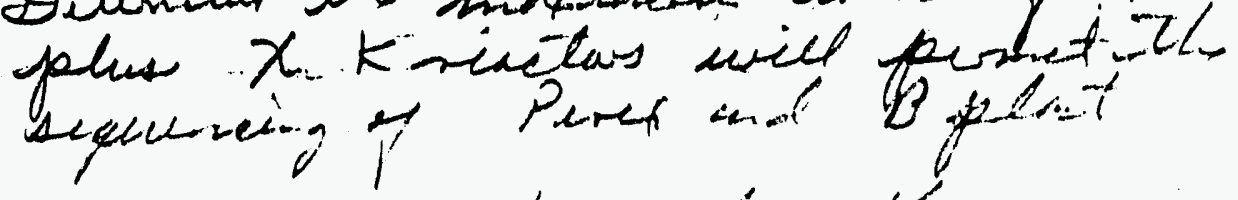

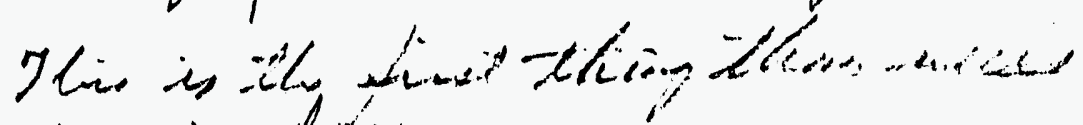
penning dacion.

$9-15-60$

- A2- SEGIIIT 


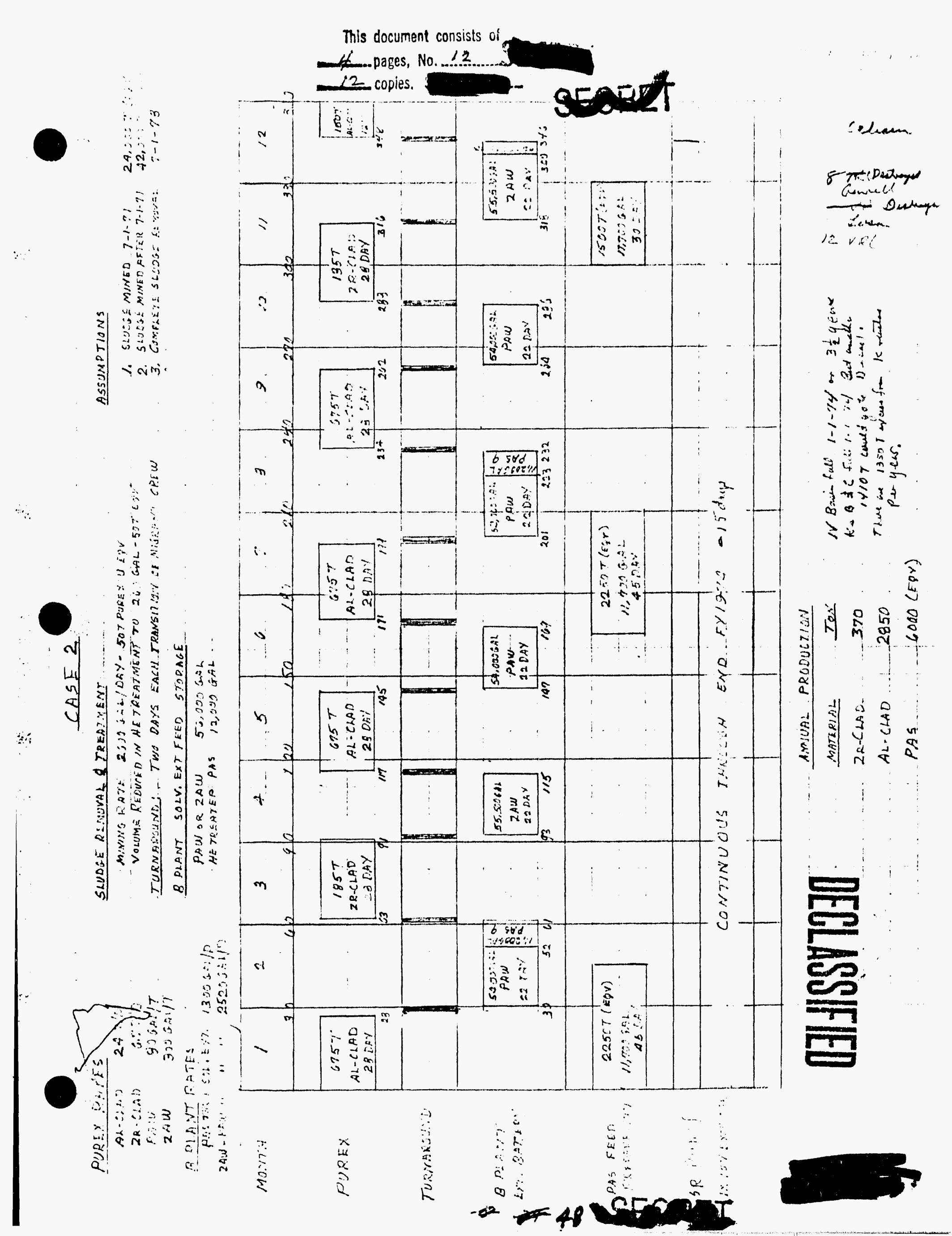




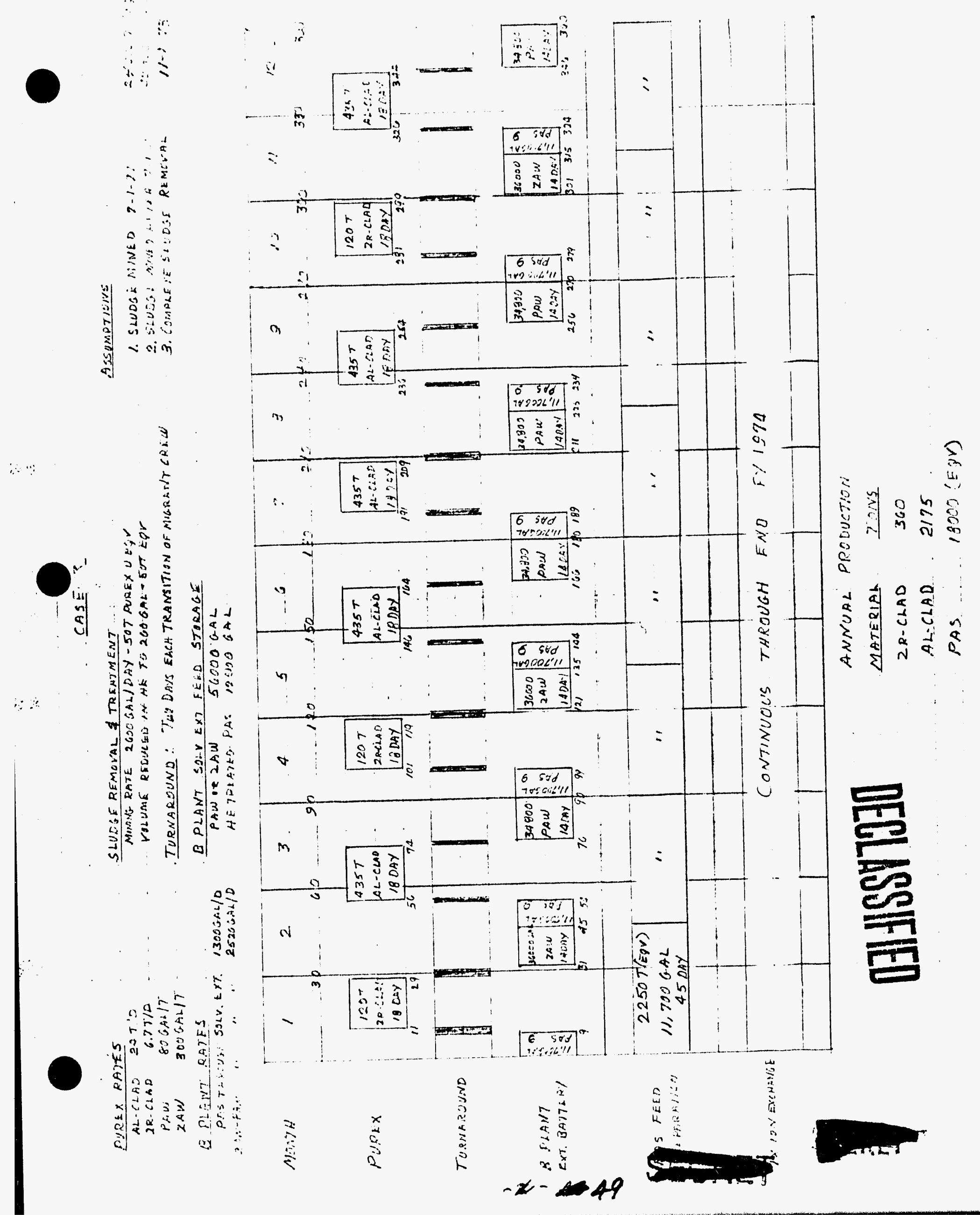


DUPSX RARES AL $2.4: \quad 2470$ $22: D=\quad \because \% T / D$ FA:

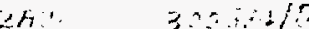

(3) PLA.Y:PTES POS THQ⿻ 2 ind
SIUAG REMOVAL ST TREAT BEWT

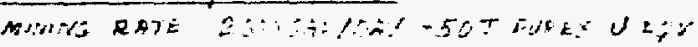

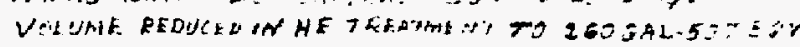

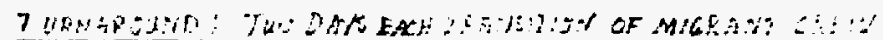

$B$ PIANT SELV, EXT, FERD ST:TLE

\section{Acurrads}

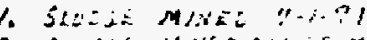

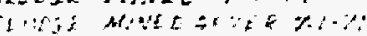

$=2$

$9-1 . \cdot$

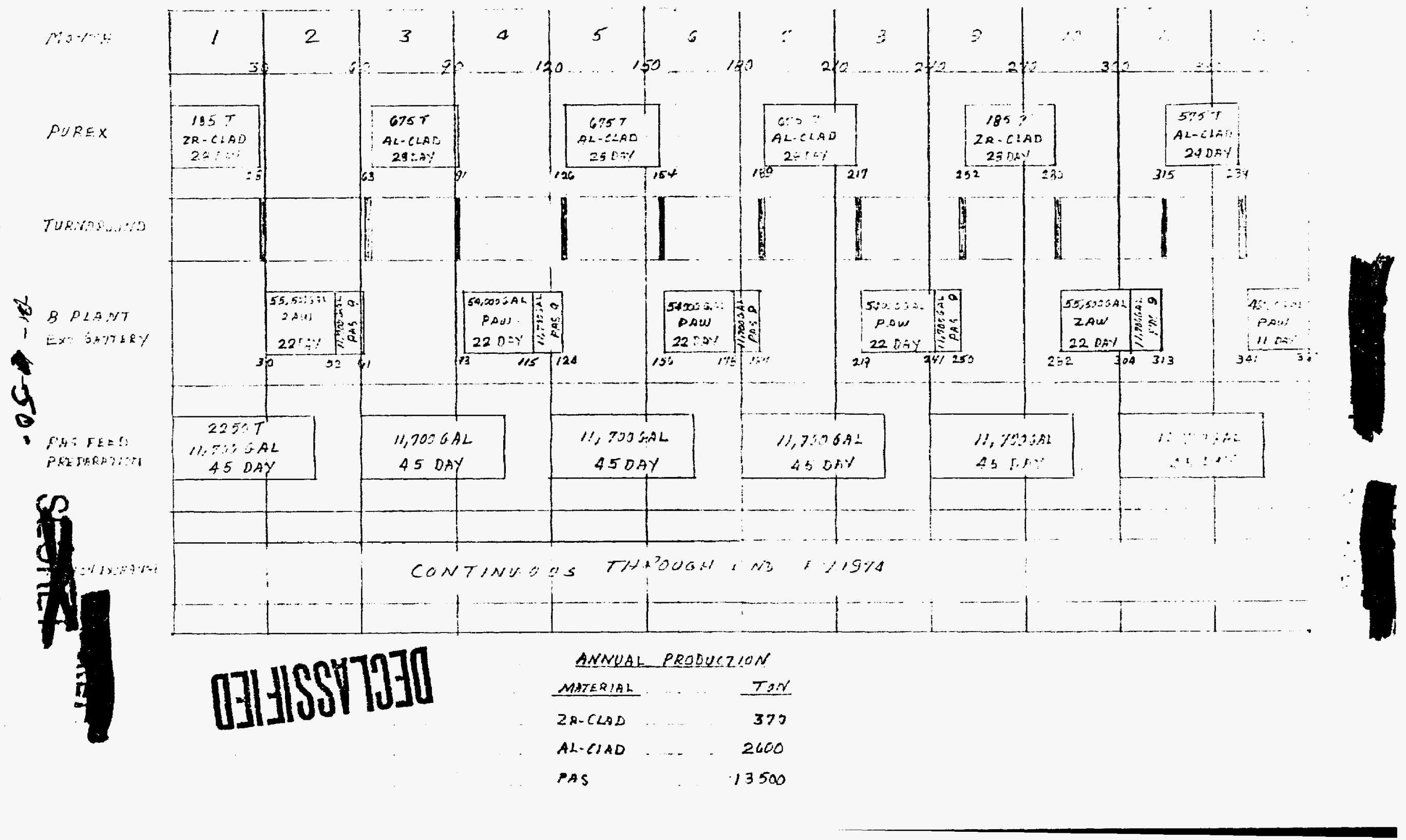




\section{REACIDE BACINE}

CASE 2

CASE 3

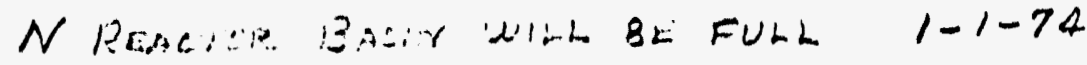

$K E$, KW, B $\neq 6$ BASINS WILA BE FULL 1..1-74

(Nothino S $2: \therefore$ O BAsir)

2295 NEW BUCKR.

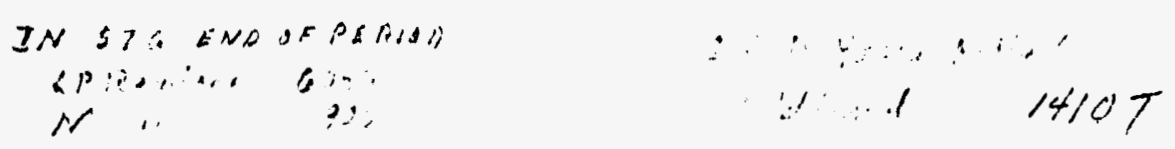

$N$ REACTOR BASIN WILL BE FULL $11-1-73$

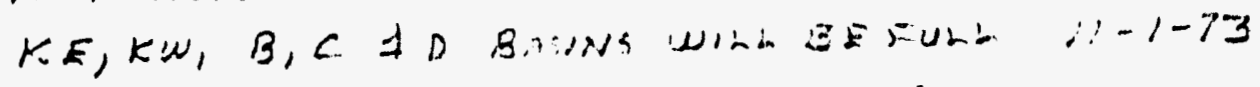

3728 NEW EUCHI: Q 250 EACH $\$ 32,000$

REOPENIST OF D BASIN TOTAL $\frac{85,600}{11,017,000}$

Ti: StP Rualis 7470

sesila 900

CASE 3 ALTERNATE

N REALTOR BASIN WILL BE FULL

$1-1-74$

$K E, K W, B \nsubseteq C$ BASING AND $1 / 2$ OF...

D BASIN WIIIBE FULL $1-1-74$

2901 NEW BUCKETSQ 250 EACH \$40,250

RIEOPENING OF O BMIV

TOTAL

$\frac{85,000}{825,250}$

$t ; ; r i a$

LP GT65
ir

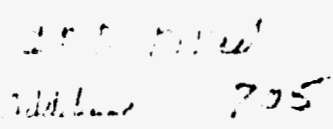


$->-1,>$ DECLISSEIED

- Whir will bivico $t E, k w, B, C, \& D$ lufilled,

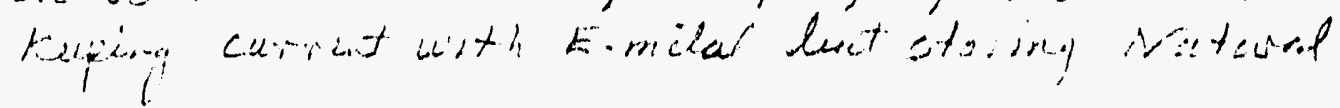

№v 2

Zr Clad
Can?

360
Q

370

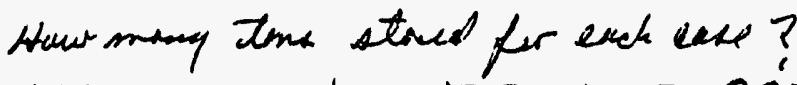

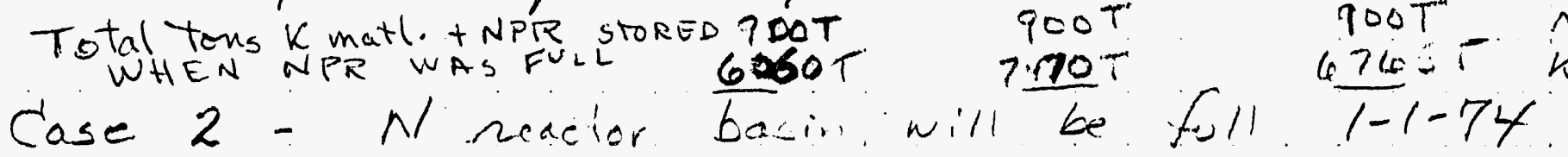

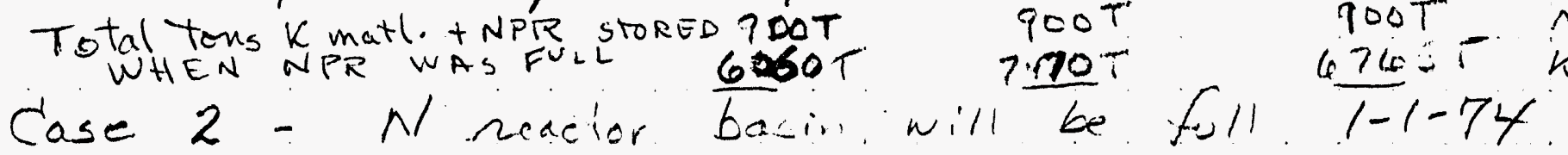

To do this requires:

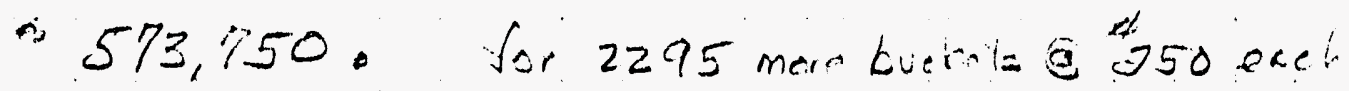

TE, KW $B+d$ basing will be completely. full on $n-1-7,4$ No material stored in D basin.

If un fill D basin, hew many mae tome? 1410 TONS NORMAL (NOE)

Case $3-N$ reactor Gavin will in full $11-1-73$

KEn, KW, $e, C D$ basins will also the full $\quad 11-1-73$

To do this requires:

\#5,000 for D basin.

1. $932,017,060$. for 3728 more butches $\& 250$ each

Cave $3(a) \quad n$ reactor basin will be full $1-1-74$ KI, KW $e+C$ basing will be complete $x_{w} 11$ and $D$ will be $1 / 2$ full on 1-1-74

eve fell D levin, haw many monet ton? to do This requires

705

$$
\begin{aligned}
& \text { स5, } 100 \text {, for I basil }
\end{aligned}
$$

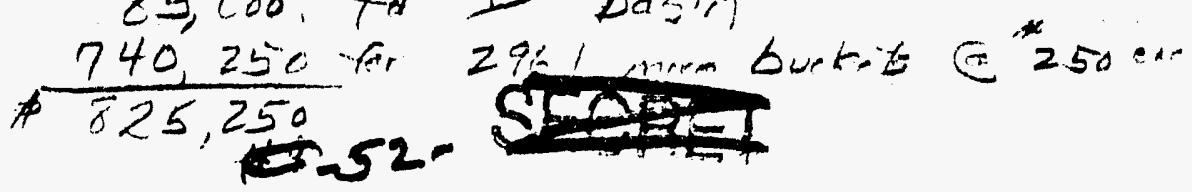


Pequot.

When will basin be Gilled?

schedule $7-|-7|$ and beyond for Murex

Zr clad 555 tanks

Al clad 2175 tons

Answer -

$K E, K W, B, C, D$, and DR basins will be ! filled at the end of FY 1974.

To do this will require:

$$
\text { * 85,000. for D }
$$

$\# 1,295,000$. for 5180 more buckets @ 250 ear $\frac{1}{41,415,000}$. TOT NPL coste

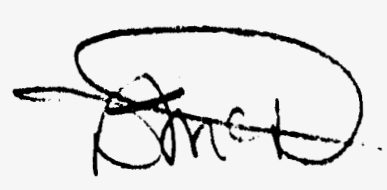

$-x=53$. 
$K E, K \omega, B, C, O Y O F, B A \operatorname{SIN} C A \dot{H}+=$

Basis

1. Situation visualized for end fr ip74, assuming Paras - B Plant sequential operation with K.K.N Reactor operation

2. Processing of $L P R 94$ enriched uranium kept current so that kI 1 kw basins' only axe used to stare this material

9. Thorium irradiation for shield protection only; no chemical. processing of thoria after the FY 1471 campacax

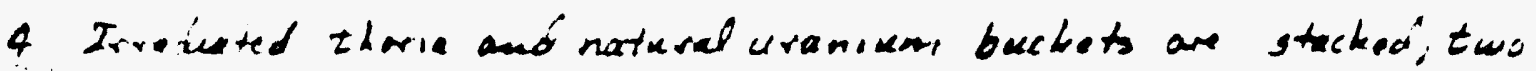
bucket, high, in th basin,; LPR gt enriched ar not stack ed

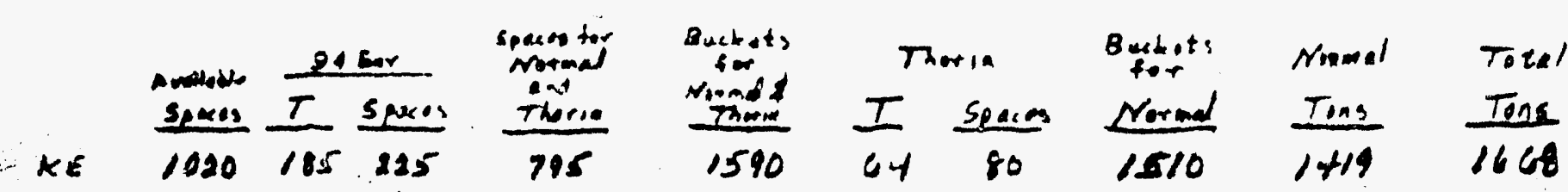

$\begin{array}{lllllllllll}\text { kW } & 1020 & 185 & 225 & 795 & 1590 & 64 & 80 & 1510 & 1419 & 1668\end{array}$

$$
\begin{aligned}
& \text { B. } 770-1501501014771477 \\
& \text { c } 700-7001400-24001314 \quad 1314 \\
& \text { D } 750-\ldots 150 \quad 1500 \ldots-1500 \cdot 1410 \quad 1410 \\
& D P \quad 835=1676=163815751575
\end{aligned}
$$

$\begin{array}{llllllllll}\text { Total } 5095 \quad 370 \quad 450 & 4648 & 9296 \quad 128 & 160 & 9136 \quad 8584.9082\end{array}$

NPR 905 9009:5 - $\quad$ - $\quad \ldots \quad-900$

DECLASIFIE 

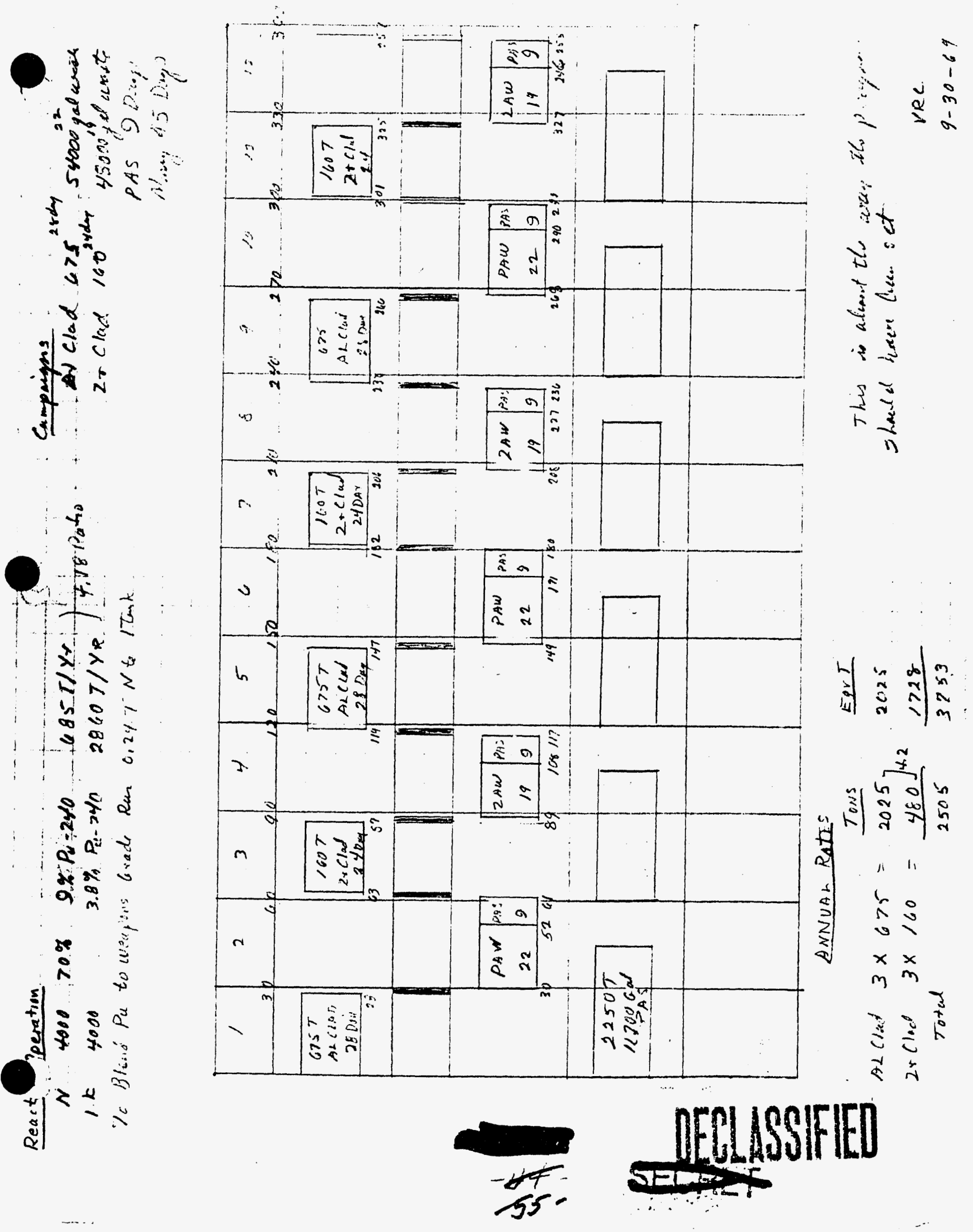


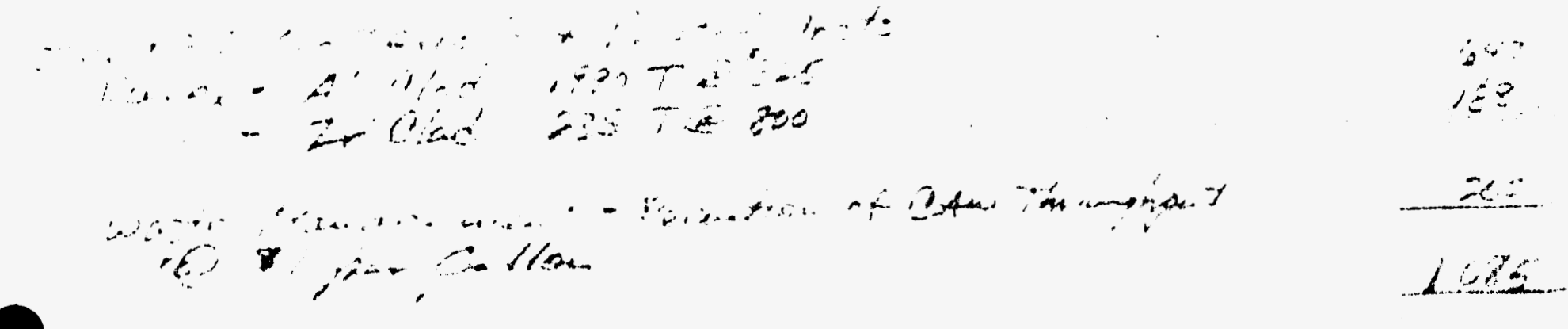

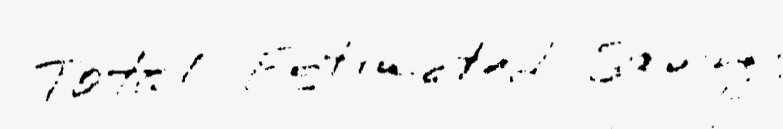

"s......ed to
218

220

Rue

$9-25 \div 69$

$\therefore$ BECLASSIFIED

76: 
U. 3. Atonic Erangy Coumicosion

Merland Opuratioun osteo

riclizani, Wasington

Attention: Is. O.J. Ilsurt, Drector

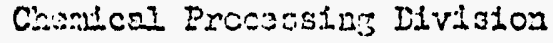

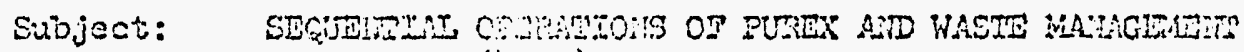
Contract in $(1)-1)-2130$

Neforances: (I) Ani-j.30e (sacrat), July 28, I969, Compilad by the strens oi: Doucles United liuclear, at al." "Mnotoly Froduction Forecast -

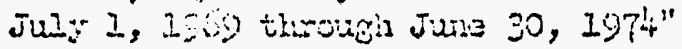

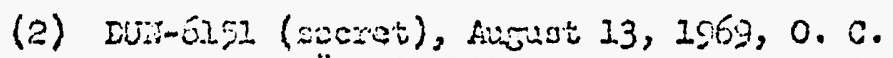

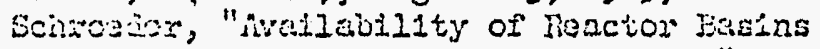

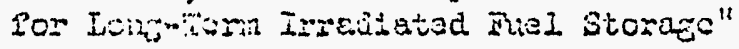

(3) Lattos, septenios il, 1959, 0.J. Jizert to R. P. Conlist, "Euquential Operations of Purox and Hecte rengerement", (DC:JiC)

Gentlenen:

In response to your lettor (roference 3) we have continusa

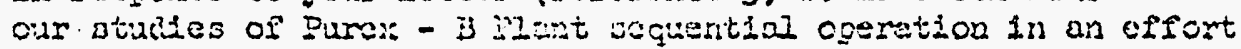
to detarwiue the earizest late that such opercition coild ba started, based on the hisulpitions in your recliost and the

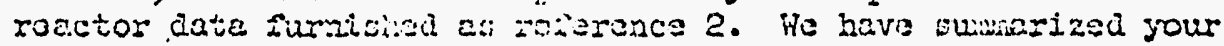
threo cases in the foliciriag inivite

Tre stiprlated nasd to ainere to tho currant U-233 campisn schecila weans tiat in no case can sequent1al opsration ba startad before July 1, 1971.

Case 1

This is a case that camnot ba made to itt. The reactor prodiction (reierence 1) is illin enough that no modirication of the 


\section{DECLASSFIED}

U. S. Atenie Exasy Cowidion

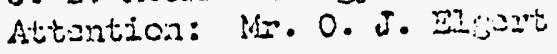

Pore 2

SEP 291969

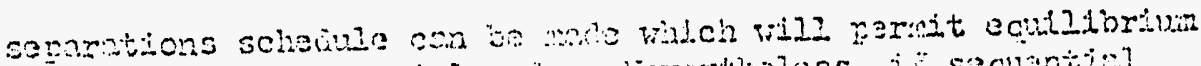

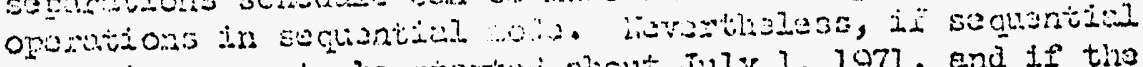

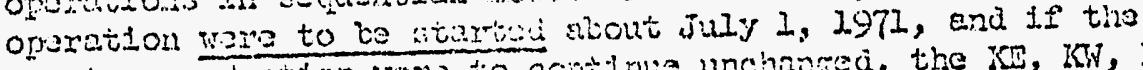

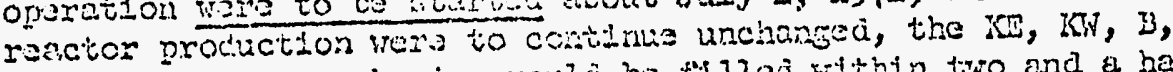

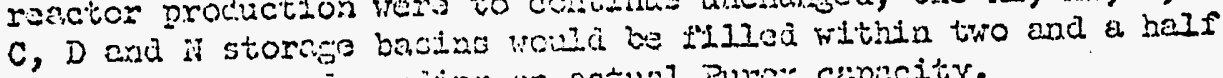
to cinres yeurs, cepending on actual Iurex cepacity.

\section{Cace 2}

This is another case that crinot be made to fit. Anelyois showe tinct regardless of the lometh of time by which achicyement

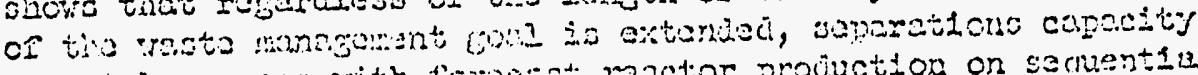

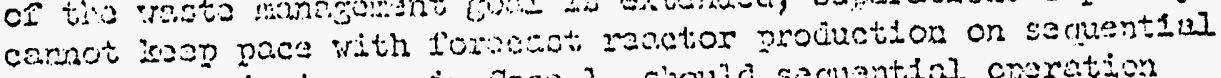
ororation. Afain, as in Gos? 1, chould secusatial chertion be started cbout suly 2,197 , ard should the raste wancestent

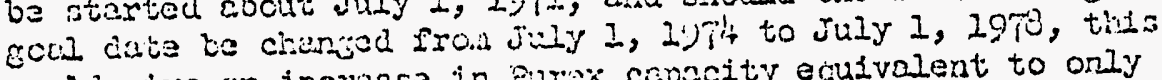
would rive in increase jn fur copacity equivolent to only about six ronths' auditional reactor basia storape tine (over Caso 1) for X Reactor cintiput und no slentficant incresse in N Reactor bestin fill time.

\section{Case 3}

Sequential opsrations couid bo started about July 1,1971 . On the bost 3 of an cpereting I? En whlch would veet the waste manage:tent goals, wo hove estimatad the equllibriun year Purex Plant copreity as folicira:

a) Approxlmutely 63 parcent of the reference 1 forecast combined it and Li-wi nouctor outputs; or

b) Approximatoly 115 pexcent of the $\mathrm{KE}-\mathrm{KN}$ comblned outputs If both renctiors were productns wesipone-crace prociuct, ond if sacctor vare siut dom or transferred to WPESS; or

c) Approxirataly 05 parcont of the coriblned output of ona I leactor plus if kecaton, operated to produce weeponserrace plutoniun blesd.

If sequential oparation kere started on July 1,1971 and no reduction in foracest roctor procisction were made, the $\mathrm{N}$ ieactcr basin wolld be f1lled approximetely Januezy 1, 1974. At this

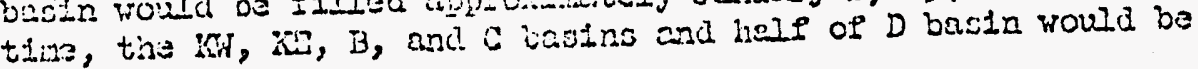
finlek. 
U. S. Atomic Enorgy Comingson Attention: Kr. 0.J. II 324

Pute 3

sip 291959

We havo rade a preliminayy estumeto of Apuco opareting costs

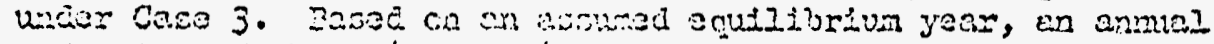

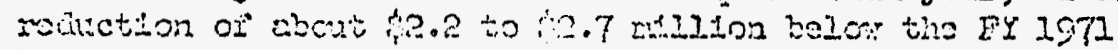

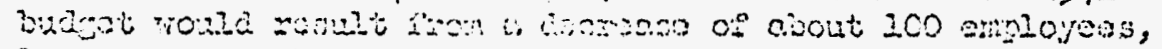

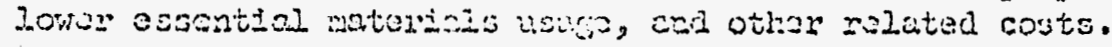

Wo vont to anphesize thet live to limbtations in time and lack of appropriate opsiating cojevionce the above study resurts

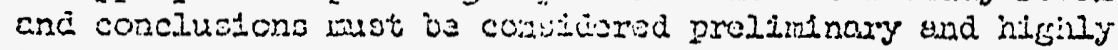
tentative.

very truly yours,

ORIGINAL SIGNED BY

R. P. CORLES

F. P. Corlci

V1ce Presicient - Oparations

RPC:Nin:ror

bcc: SJ Eeard

LI Brecke

RW Calhoun

VR Chapme.z/D McDorald

RP Corley

Eil Dobbs

IIS Harmon

W Farty

CW Malody

TA MeCoy

RW VicCuIIugh

IM Richarcis

S.l Sciultz

IIP Shaw

AT Smith/HY Hopkins, Jr.

WG Smith/AD Garrett

Re Smiti

R' Tomlinson

Jil Varren

ARHCO Central File 
C. Bequential Operation of Purex and B Plant

We have looked at sequential Purex and B Plant operation and find it is possible ii total fuel throughput is less than about 40 percent purex capacity and completion of in-tank solidification can be deferred several years. This is possible vith the $9-5$ blend reactor mode operation and either reauced reactor power ( $K^{\prime} \mathrm{s}$ at $3,000 \mathrm{MW}$, N at minimum power for electric power production) or shutdown of one additional reactor within about the next year. ARHCO, however, recommends this course of action not be taken until completion of Thoria Campaign at the end of CY 1970, Because of the added training requirement and need to resolve certain vaste management problems. Purex and 3 Plant would be operated on approximately alternate months as dictated by acid waste storage capacity. Some sluicing of stored wastes would be continued but at a very low rate. Preliminary study based on 9-1-69 decision; six months transition and training period, manpower reduction 100-150 on March 1 , 1970 with some addition reduction about one year later. Savings in FY 1971 would approximate \$2.2M. Possible penalties are:

1. Ertension of Waste Wanagement solidification date by an additional 3-5 years. Thus increasing potential for additional leakers.

2. Waste Management operations needs about one year to work out sluicing, settling, sludge processing, solids problems, and some equipment problems. Initiating sequential operation now would result in an inability to solve these problems in a reasonable length of time thereby further delaying solidification of wastes.

3. Incureased risks of operating incidents due to complicated training required to qualify operators for three jobs; i.e., Purex Elutonium, Waste lianagement, and Purex Thorium.

4. Inability to meet VSEP requirements for sulfate-free wastes and possible cerium. 
$\frac{605}{9 / 1169}$

Transertion axd trameng

Sequental Efretis

$3 / 1 / 70$ Han puent kitued

Seviriss

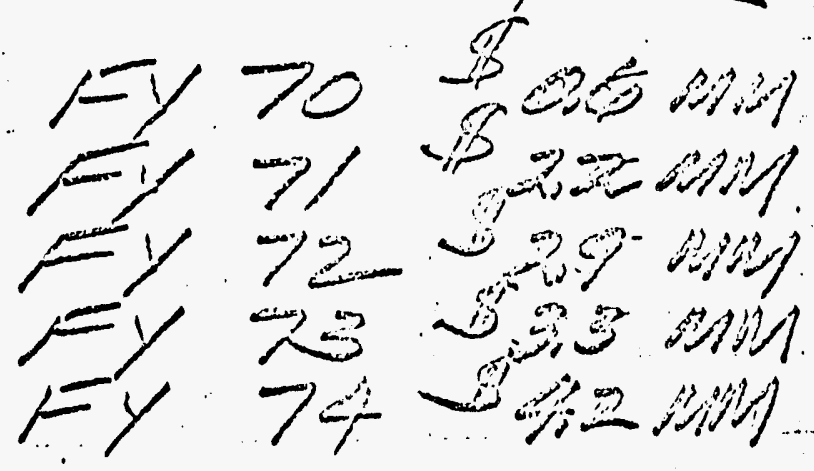

DECLLSSIFED

$-61-$ 


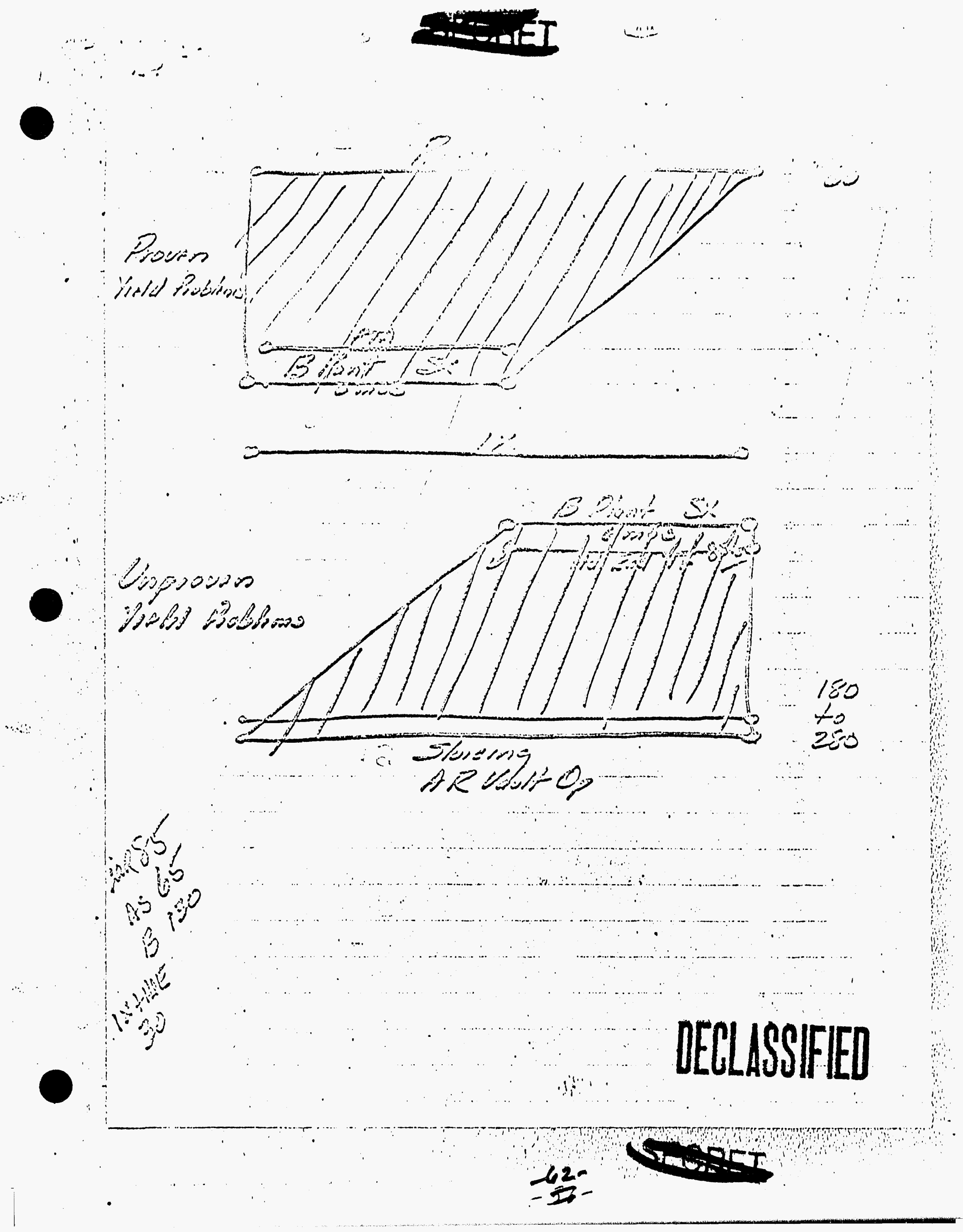




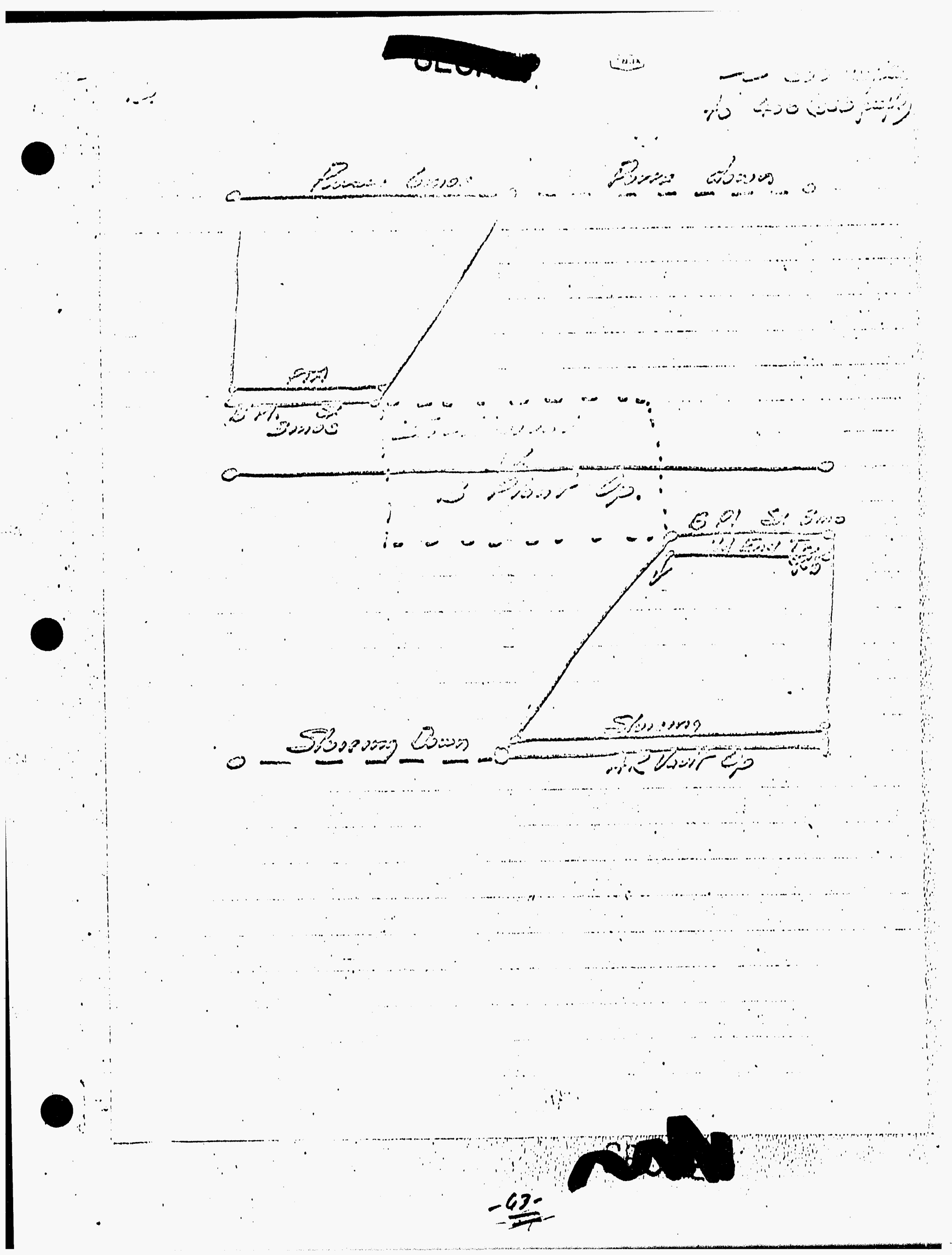


OEELLSSFFED

Foly

Stop minny woth Ginl

10) Hisertralian

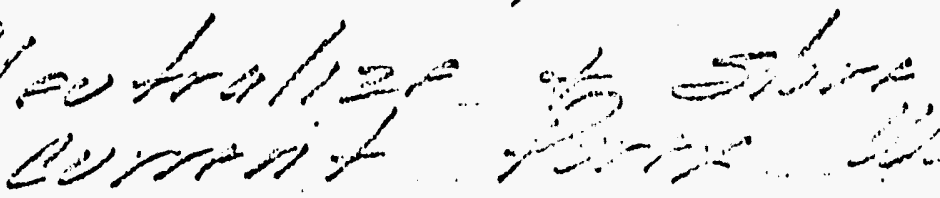

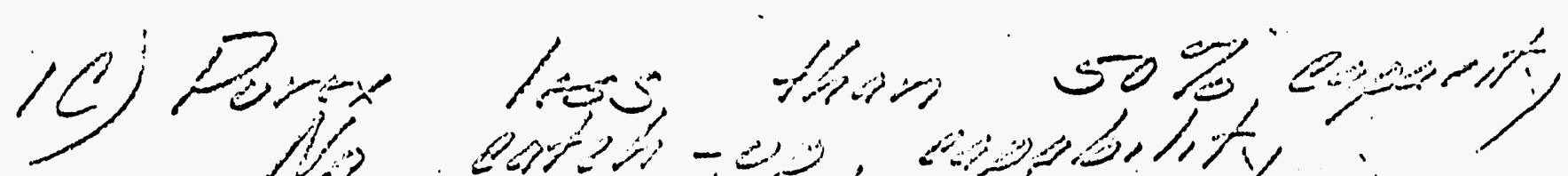

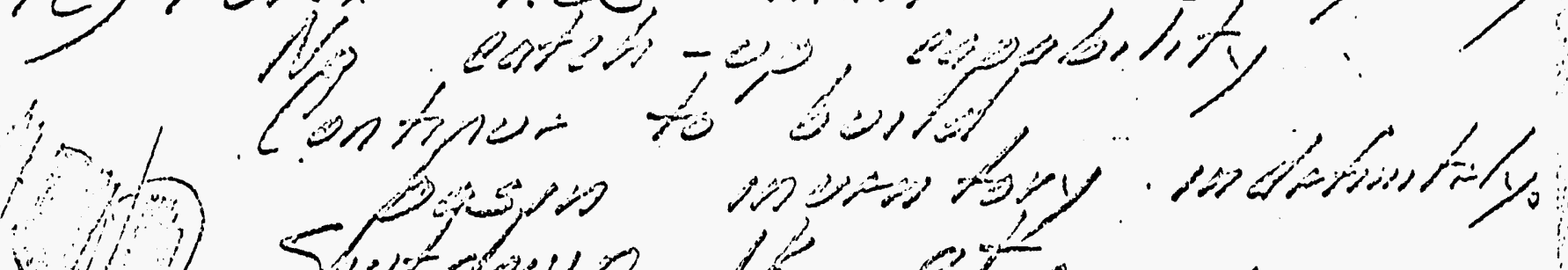

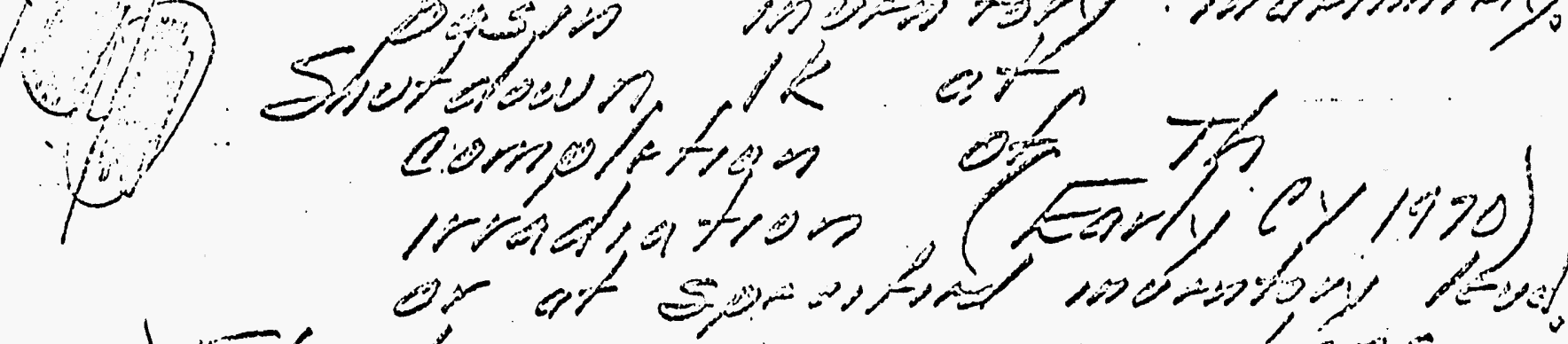

2e) Slowdown migny poration

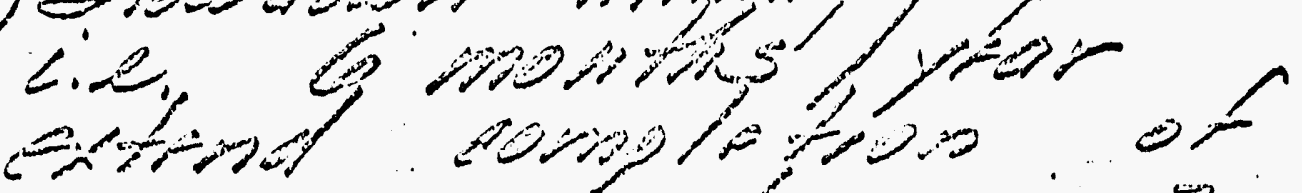
mining operefions z-oyeds.

se) Supend $\theta$ Pist

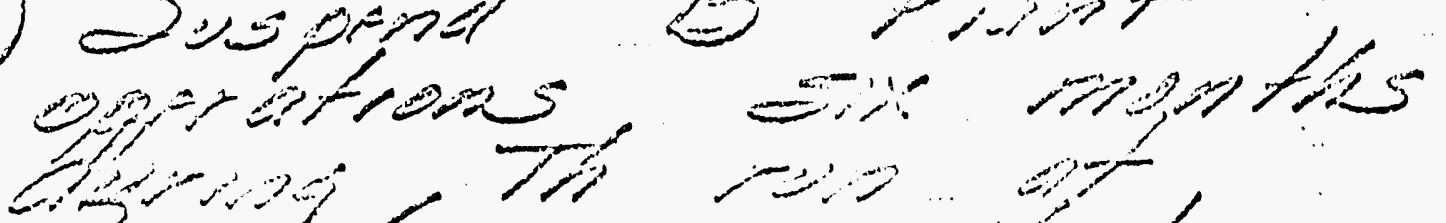
prisf (cin verrativi 
(1)

1,

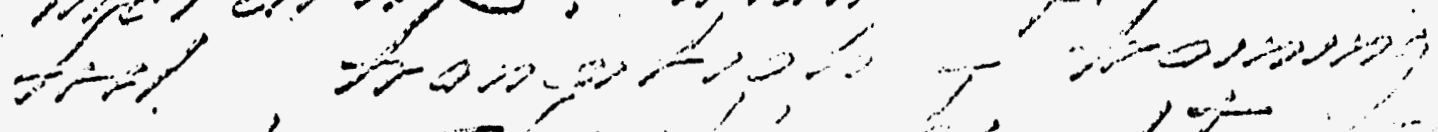

अiिक्ष

舟,

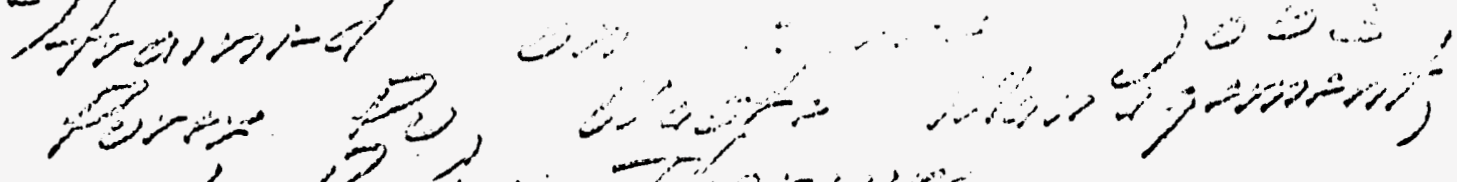

(1)

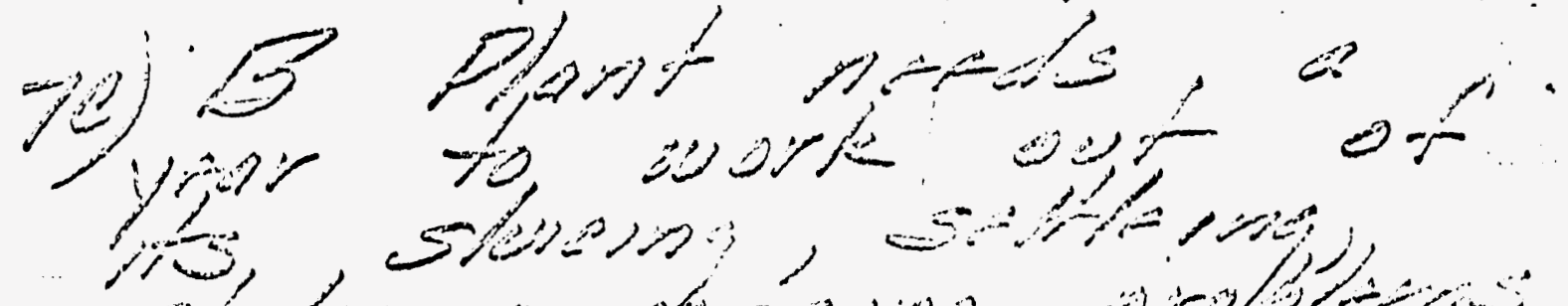

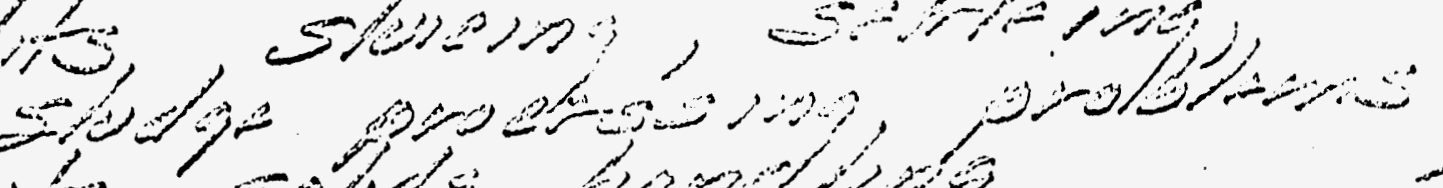
14 ,

1)

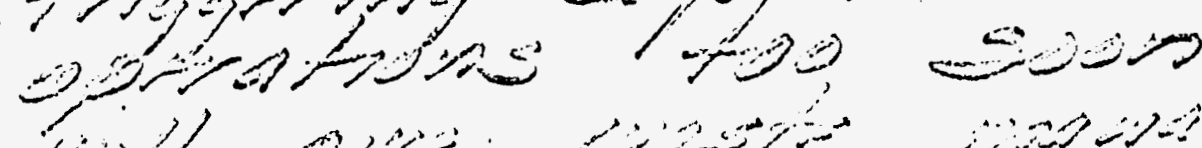

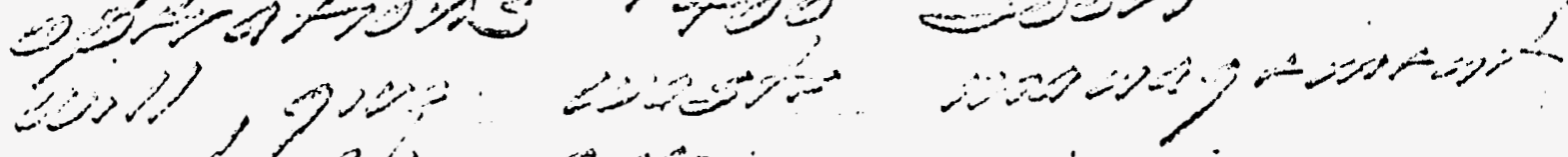
$\rightarrow$ Oid Pis

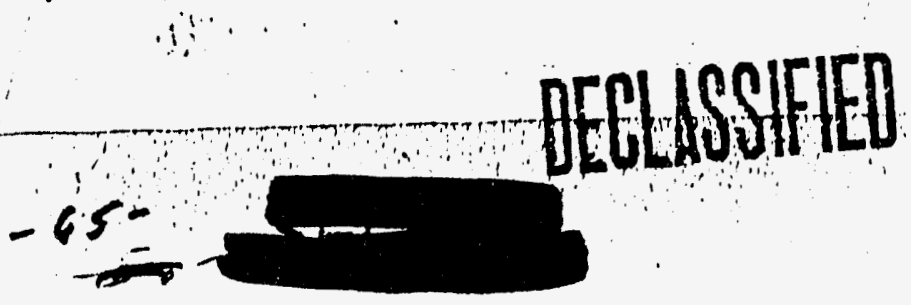


$\therefore$

\%

\%

要

7i) ARHE - 



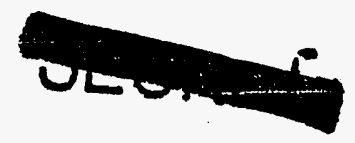

To: V.R. Chapman

From; D. E. Larson

Subjoct: B-PLANP CAPACITY

Ref: 2. D. E. Larson, "B-Plant - Phase III Flowsheets", ISO-986, August 31, 1967.

The following B Plant capacity information is provided

to assist you in determining the operating conditions

for whlch Purex and B Plant may be operated sequentially.

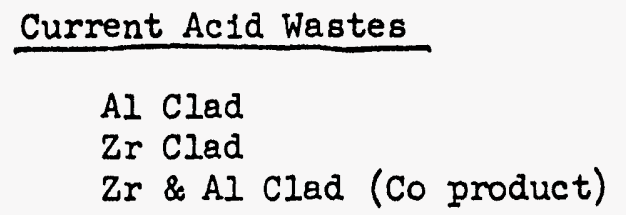

Case $\quad$ Assume

Capac1ty

gal/day

$100 \%$ eff.

Centrifuge 1. CAW solids treatment in centrifuge 2000

Solids Treat. 2. HEDTA leach solids treatment

(Present)

3. Solids treatment capacity IImiting

Tank

1. CAW solids treatment in tank

3500

Solids Treat. 2. HEDTA or caustic-carbonate solids treatment

3. Solids treatment and solvent

extraction about matched. The solids treatment time cycle could probably be cut to make solvent extraction limiting.

4. Contacting essicinucy and solidsligwid sepamations problems regmira

No solids

1. Less than $5 \%$ strontium on solids

5000

Treatment

2. Only solids treatment would be their removal by centrifuging.

3. Purex would make appropriate process changes to avold strontium assoclation with solids. Such changes could be:

a. Reduction in $\mathrm{CAW}-\mathrm{SO}_{4}$

b. Reduction in CAW-Si

c. Reduction in CAW-AI

d. Reduction in $\mathrm{CAW}-\mathrm{Fe}$ 


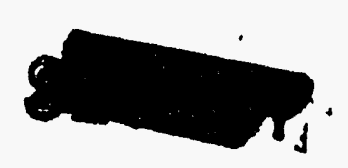

V. R. Chapman

Page 2

1. 4. The LAF" pump and flow meter would be changed such that

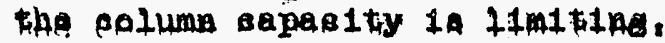

If the caustic-carbonate solids treatment process were performed in the centrifuge, B Plant CAW capac1ty would be reduced to about $1600 \mathrm{gal} /$ day. Other pracessing probums

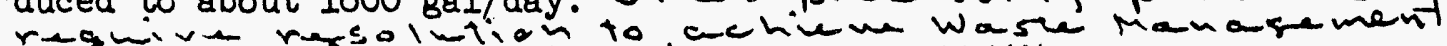
gool stronistim and cesimm recovery.

$\pi$ Ion exchange processing can proceed almost independently of CAW or PAS processing at the following capacities:

$\begin{array}{ccc}\text { Material } & \frac{\text { Processing Rate (gal/day). 100\% Eff. (ReS.1) }}{\text { Present }} & \frac{\text { Targeted }}{20,000} \\ \text { PSN } & 16,000 & 40,000 \\ \text { PSS } & \text { Not processed yet } & 23,000 \text { (D11. 1:1) } \\ \text { RSN } & \text { Not processed yet } & 1,800 \\ \text { CAW-Cs } & 1,500 & \end{array}$

The inter t1es between 10n exchange and other processes are the following: PSS must be processed at a rate of $1,400,000$ gallons per year in order to process the sludge through $B$ Plant from the tanks per year. There 1s only 500,000 gallons of lag storage for PSS in TK-106-C in the C Tank Farm, wh1ch sets the maximum PSS accumulation volume without affecting PAS processing. Steps may be implemented to increase this storage capacity.

For every 28, 000 to 32,000 gallons of CAW processed through B Plant which is treated for ceslum removal by PTA processing, an 1on exchange purfication run is required. Th1s run

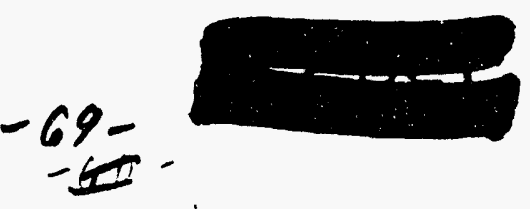


V. R. Chapman

Page 3

campalga will require about 2 days. There is about 150 gallens of Cs-PTA product generated per 1500-gallon batoh of CAW-dlluted supermatant ( $1400 \mathrm{gal}$ CAW supermatant and 100 gal water), and 3000 gallons of lag storage for th1s product. This frequency will vary in the future with changes in CAW-Cs concentrations and process technical advances. A different exchanger is required to process RSN than PSN, but PSS and PTA-Cs product may be processed on both exchangers.

There is not sufficient data on sludge processing in sluicing, $A R$ Vault processing, and $B$ Plant processing that throughput 1 rates may be meaningfully established based on experlence. Therefore the rates in the peference are still the best avallable. PAS processing may be performed independently of $\mathrm{CAW}$ and 1on exchange processing to the following extentr. When 12,000 gallons of PAS metallic 1on removal product has been accumulated, B Plant processing must cease unt1l a campaign 18'1nitiated through solvent extraction. When 12,000 gallons of PAS metallic 1on removal product 1s accumulated, 5600 gallons of PAS Th-Plant matallic ion remera accumulated, 4200 gallons of PAS 18 in meterIIC $10 \mathrm{~h}$ remover proopaing processing Plent; 13,000 gallons of PAS in TK-003-CR; 4000 gallons of PAS in TK-004-AR; and TK-002-AR 1s full of sluiced sludge; all PAS processing and sluicing must stop unt1l a B Plant solvent extraction campaign is inftiated in B Plant. Also

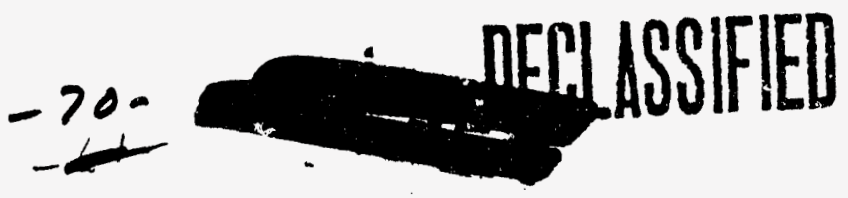


V. R. Chapman

Page 4

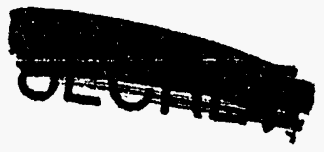

PSS must be processed through B Plant at such a rate as indicated in the reference so lag storage of 500,000 gallons in TK-106-C 1s not exceeded.

A reasonable over-all process operating efficiency is

. 72 percent. This efficlency is comprised of 90 percent operating efficlency and 80 percent mechanical efficlency.

DEL: jas

cc: DE Larson

PW Smlth

File

IB 
Jinusy 30, 19 :

Stous an issed

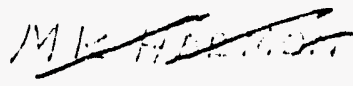

DECLASSFEC

$$
\begin{aligned}
& \text { VPCH RPMAO }
\end{aligned}
$$

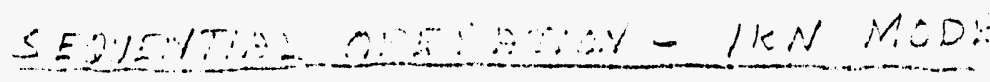

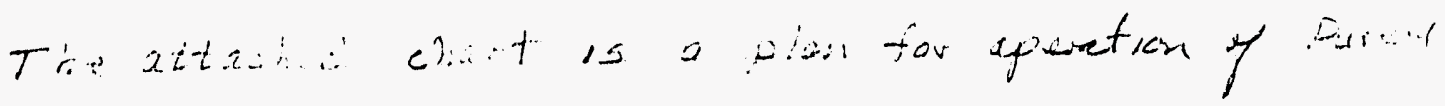

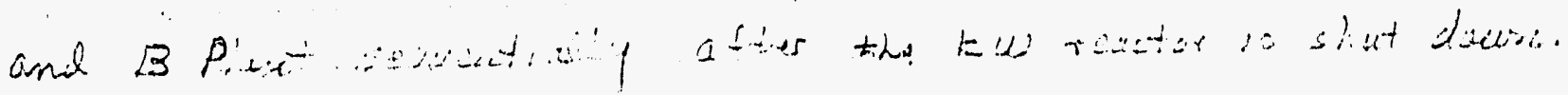

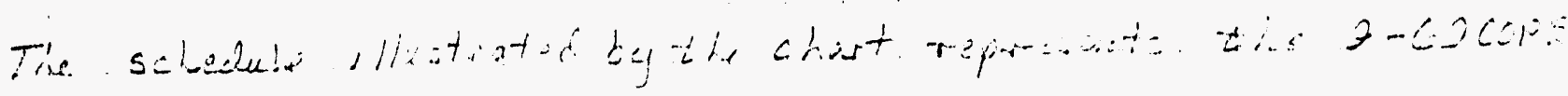

case 01-BX-101 load reikent by abat one-thind so that

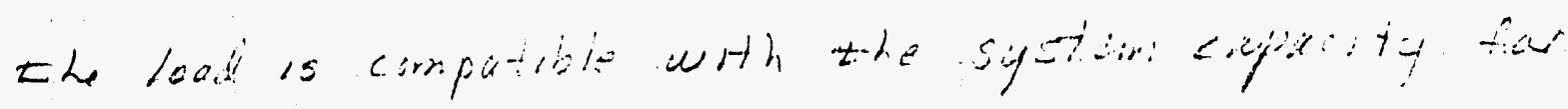

Segential operation. Case 01- BX-101 assuried the Pu- 2.20

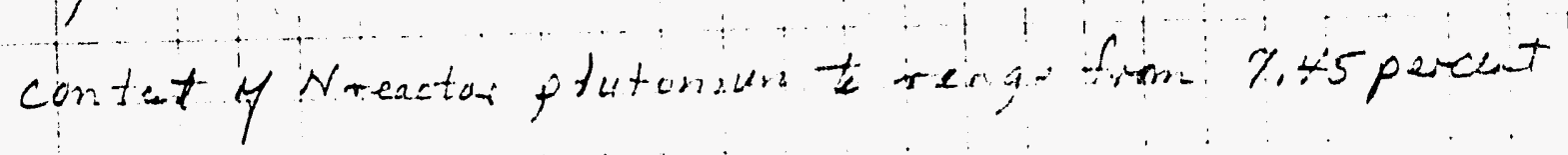

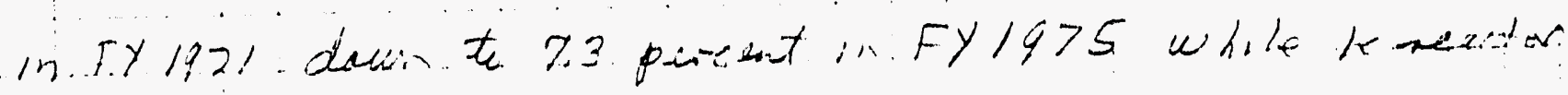

plutorium whll contan 5.0 percut Pu-240

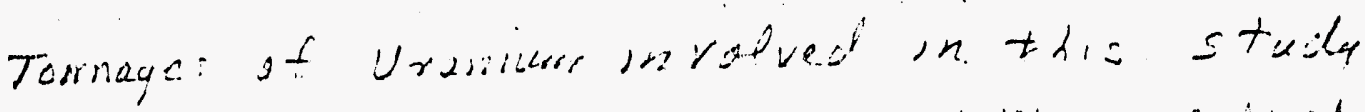

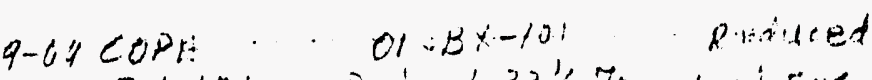

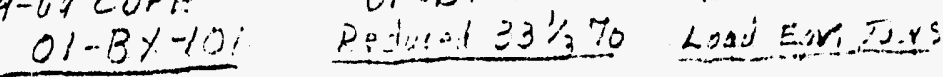

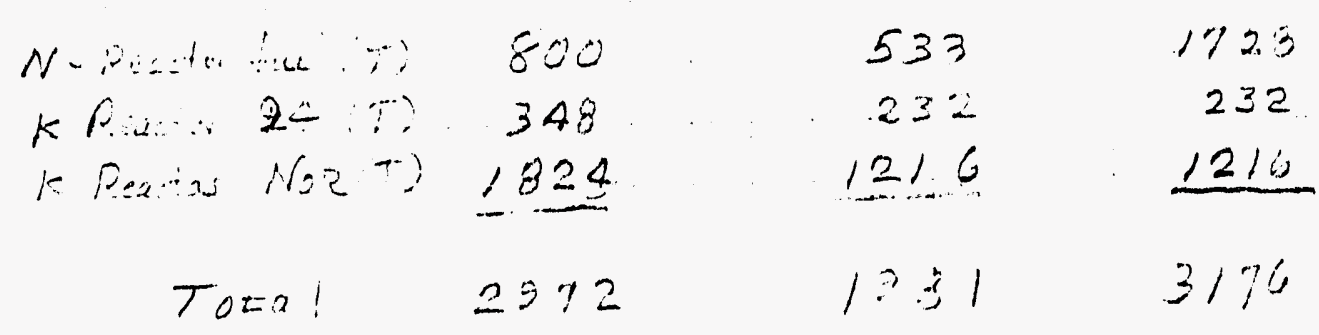

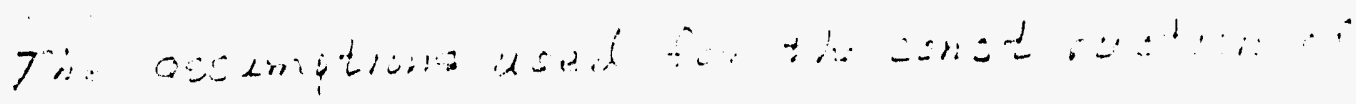




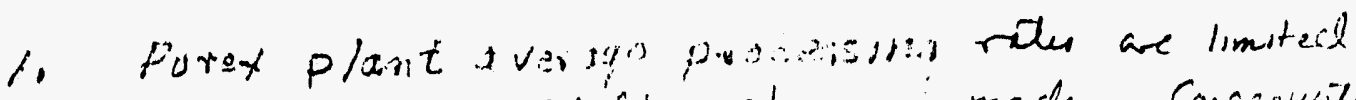

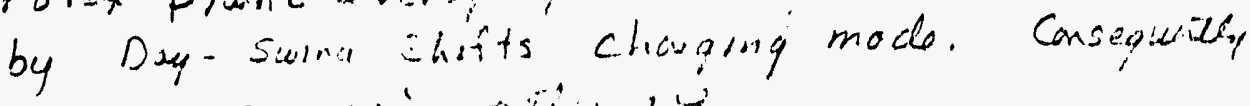
revinge prowating rit:

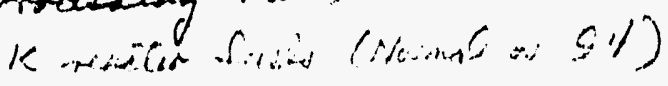

$21,10 T /$ dan

$N$ menoto fuels

6.7 T/day

2. Purce gevintef wast rand

$$
\text { ZAW }
$$

PAW

$\begin{aligned} 300 \mathrm{jal} / \tan & U \\ 80 \mathrm{ind} / \operatorname{tin} & U\end{aligned}$

3. B Pizat averequ procassing vates

CAw through $S X$

Prepared PAS

$2000321 / d 24$

$1300 \mathrm{gal} / \mathrm{day}$

4. Lag storige.

Unneatralized CAW

Prepard PAS

$55,000 \mathrm{gal}$

12,000 gal

5. PAS preparation rate $11,700 \mathrm{gal}$

45 days

C. Tire lost from end of compaign in Pures as B. Plast and s tart of carmparan in B Blentor Peocer

2 deys $^{s}$

For this particuler studi, the time arailable

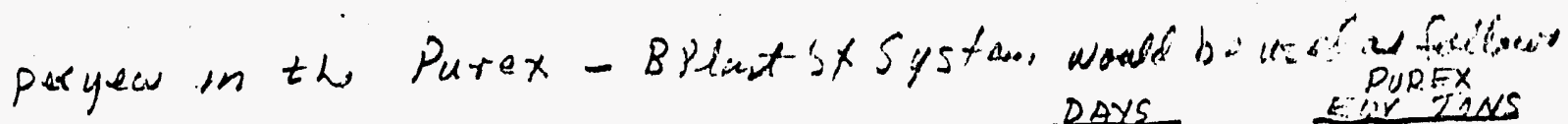

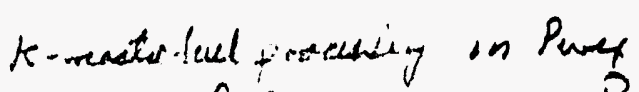

$N$ - reacter fuer procuscina ios Pures

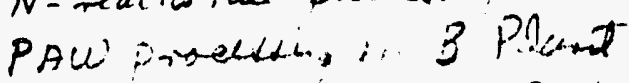
2Aw Prowestif in B P.tid PAS procuewing in 13 Pint Tronufur of crews bilus plinets

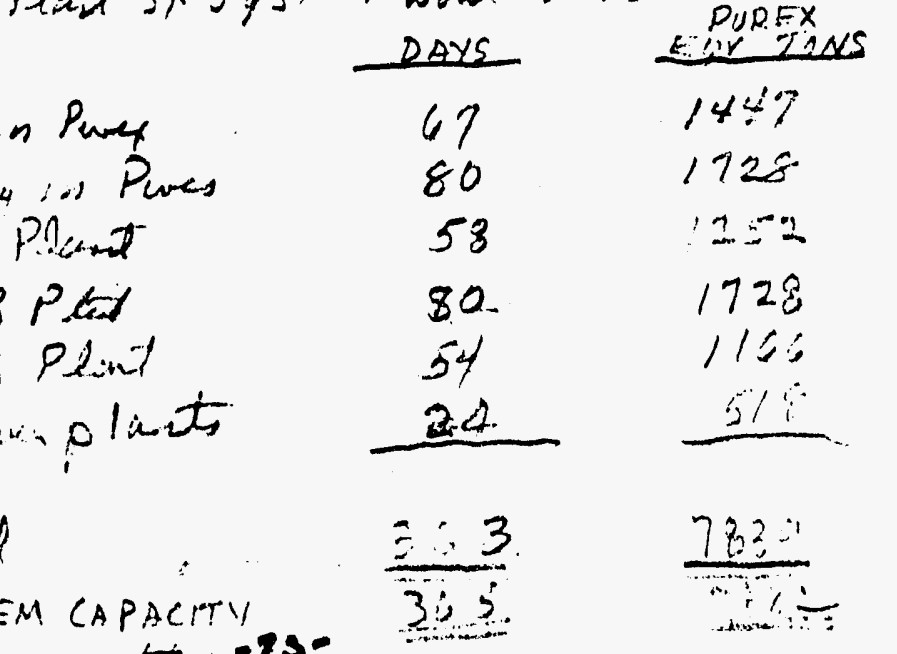




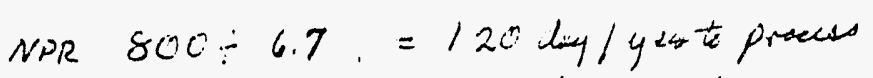

it $2772 \div 21.6=101 \mathrm{~d} y / y_{\text {en }} t$, prese

\$F 2 AL $140,000 \div 2000=120$ dy/yer-to prow

PAW 173,760:2000 = $87 \mathrm{dy} / \mathrm{y}$ ow to prewar

PAW $2.2 \times 2 \quad 4: 4$.

Bisect $6.1 \times 2 \quad 1.8 .8$

$800 \times 300=240,000 \mathrm{gadl} 2 \mathrm{AW}$

$2172 \times 50=173,768$ gal PAW

$2+900=+20$ den ty

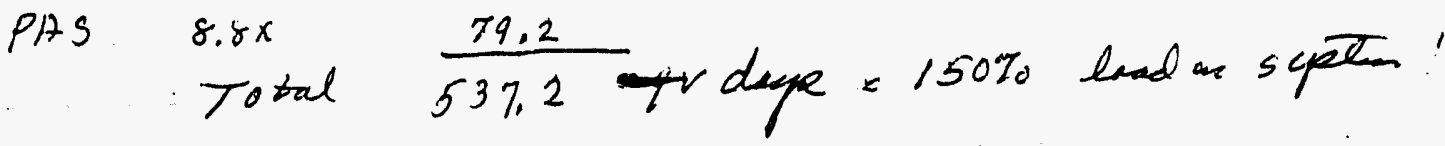

Reduce Load by $33 \frac{1}{3} \%$

NPR. $538 \div 6.7=80 \quad \frac{\text { Eg Tons }}{1728}$

$533 \times 300=159,900 \mathrm{gal} 2 \mathrm{Al}$

K $\quad 14+8 \div 21.6=6.7 \quad 1+47$

$1448 \times 80 \quad 115,840$ "PAW

LAW $159,900 \div 2000 \quad 80 \quad 1728$

ZR congius / yr 3

PAW $115.840 \div 2000 \quad 58 \quad 1253$

A) Clad Toted $\frac{3}{6 \text { carpings } A P l} P(y)$

TA 6 Pranging

PAS $6 \times 9$

$\begin{array}{r}24 \\ 548 \\ \hline\end{array}$

TOTAL $\quad 363$

System Cup $360 \quad 7776$

$-4.74-$ 


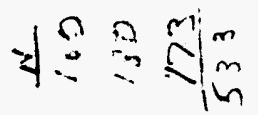

范
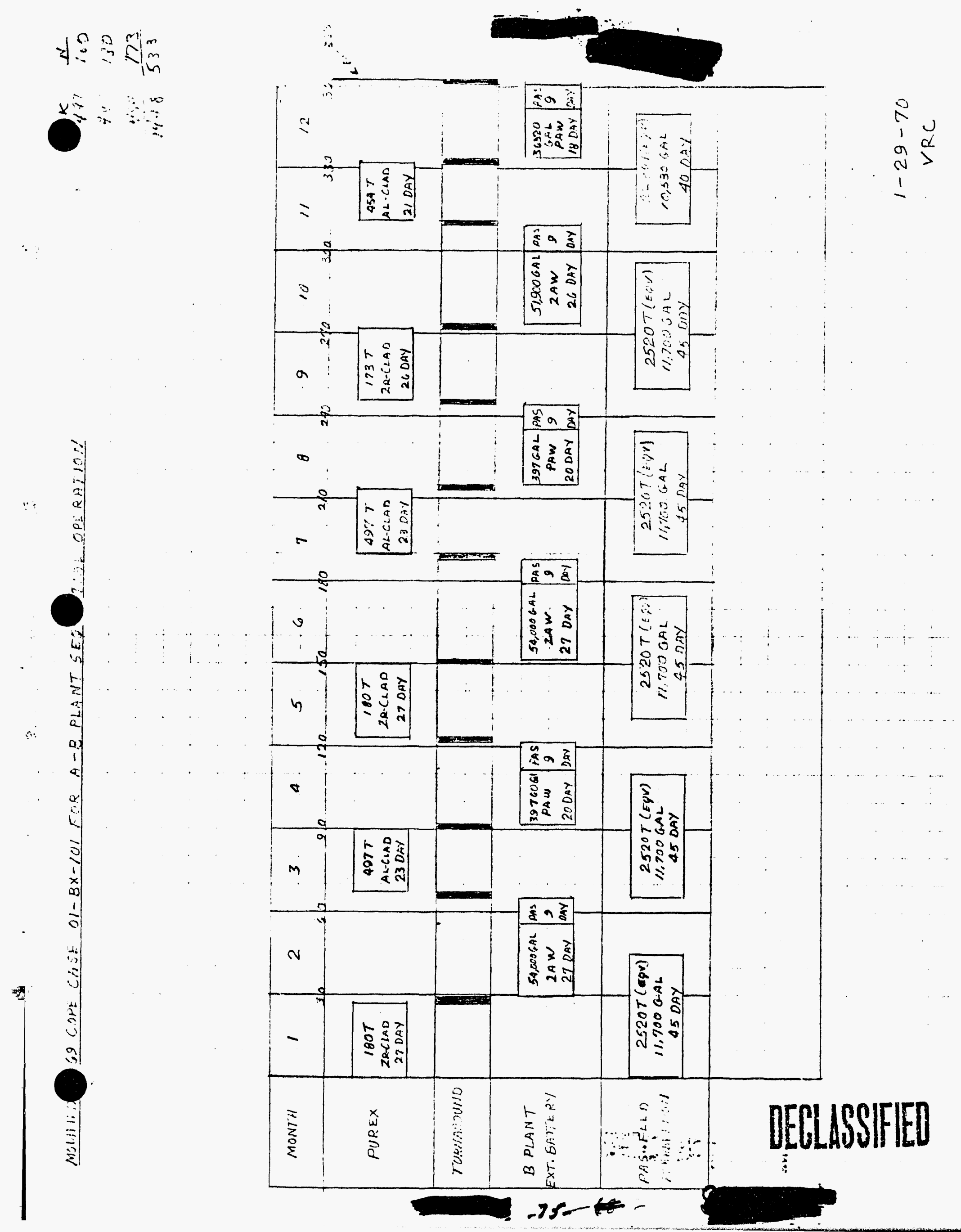


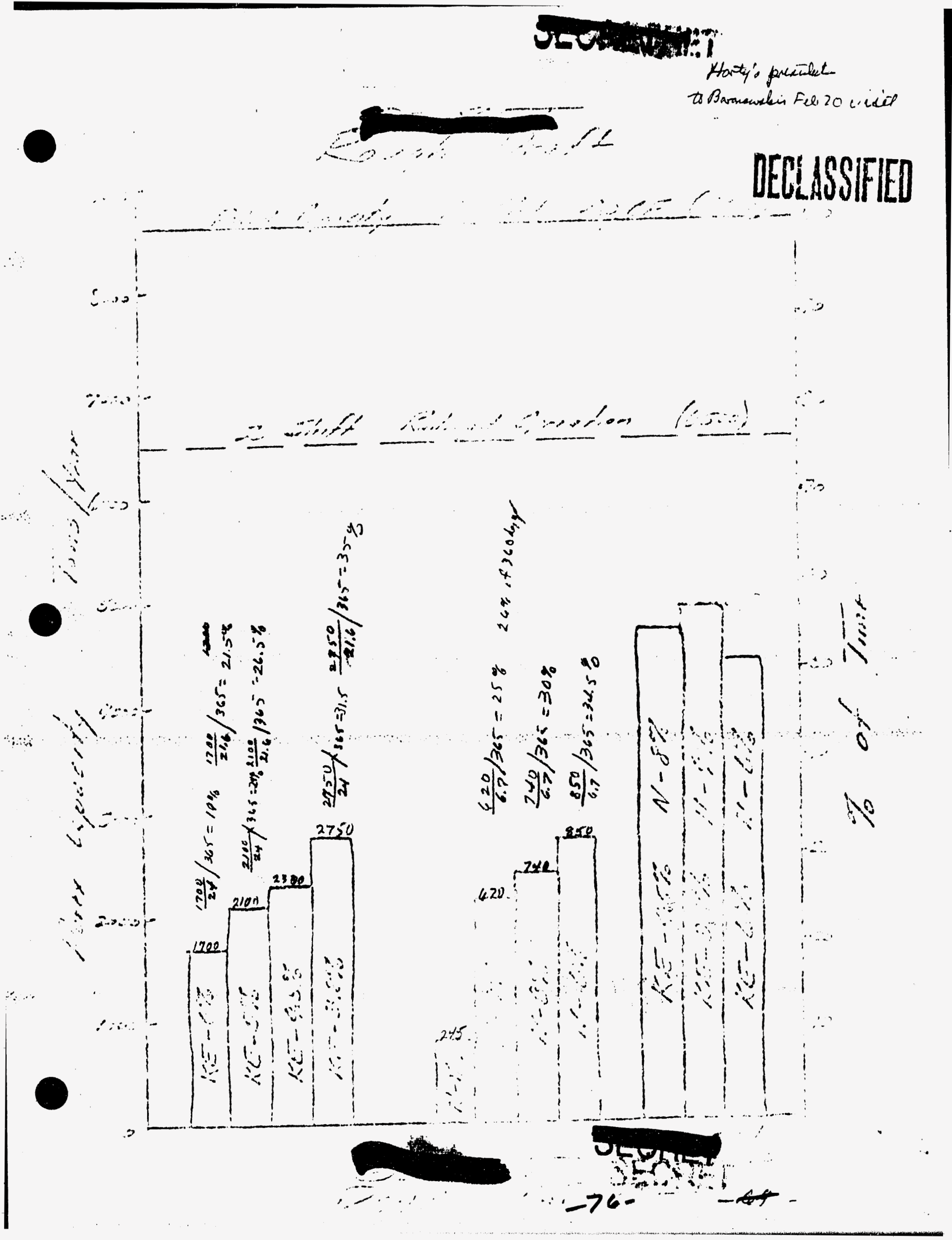



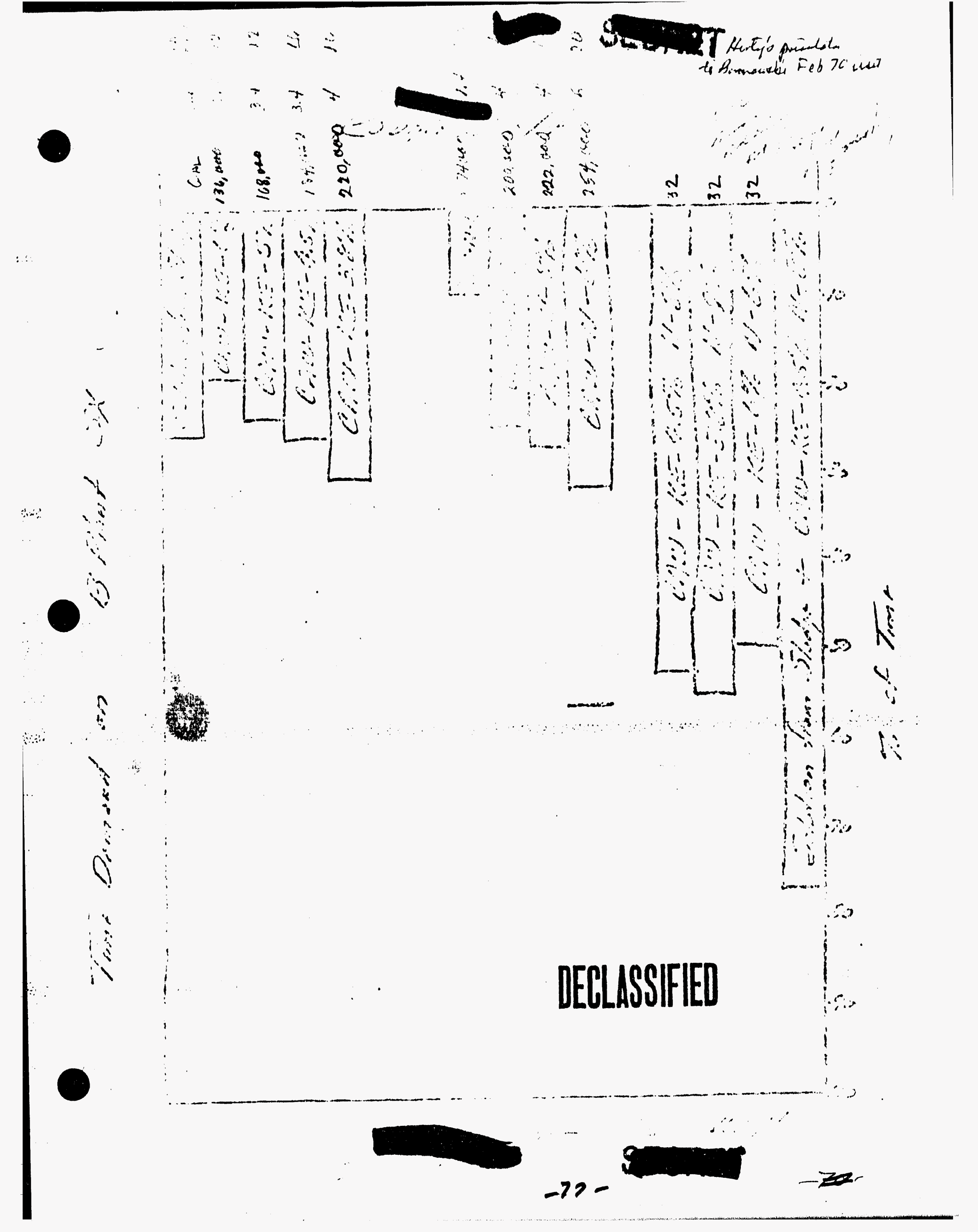


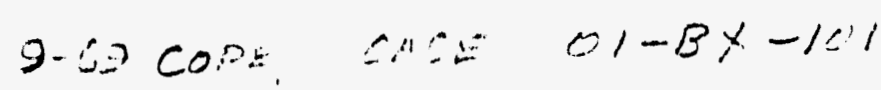

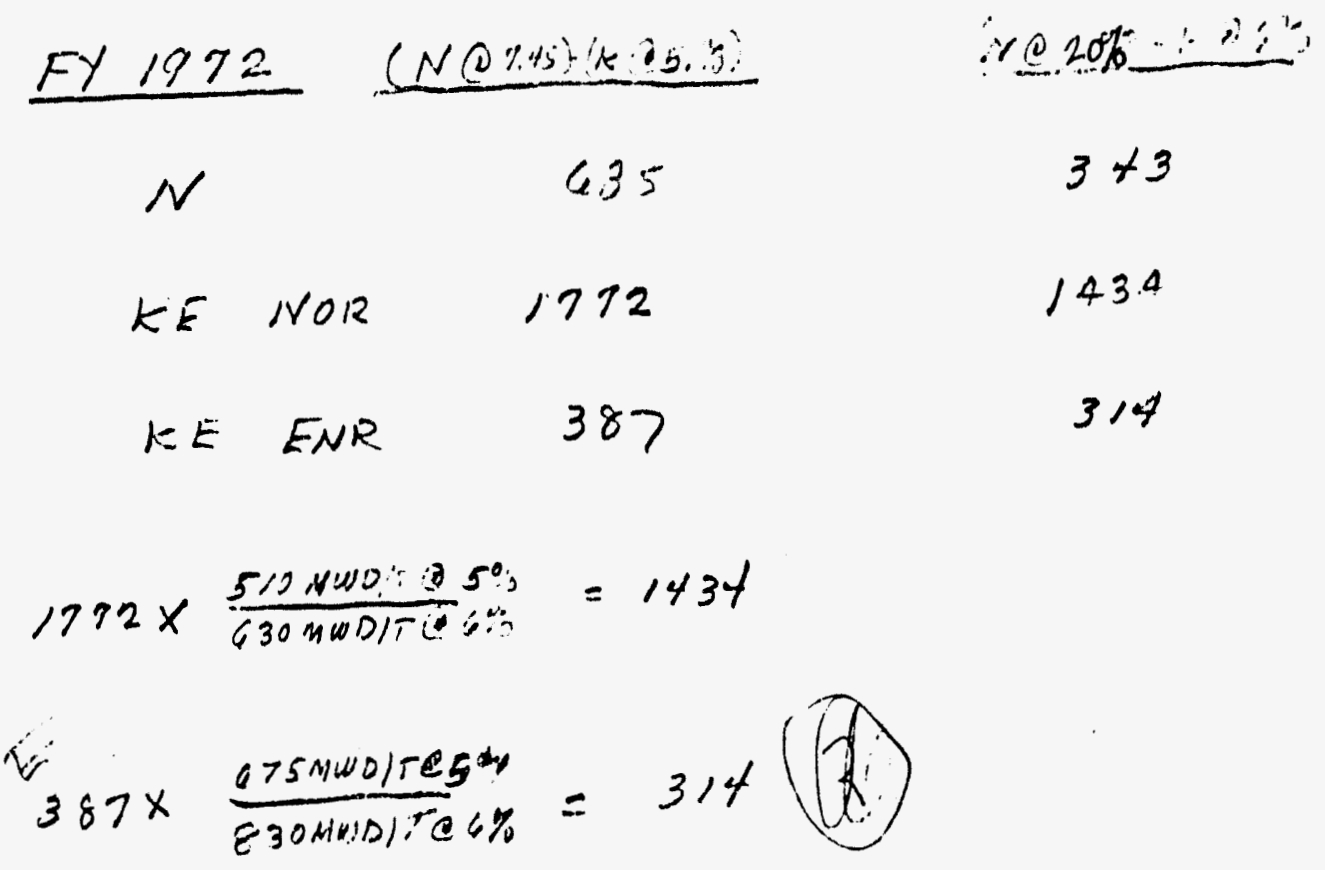

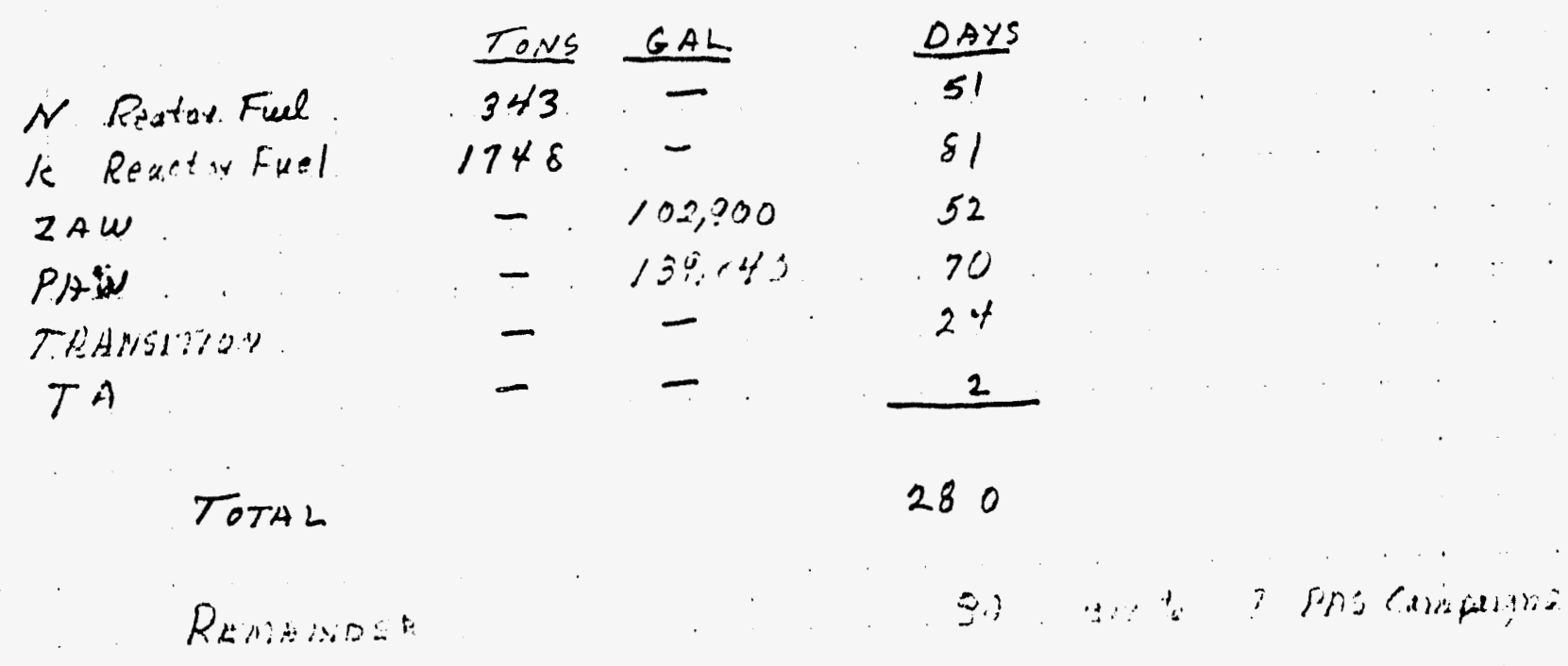




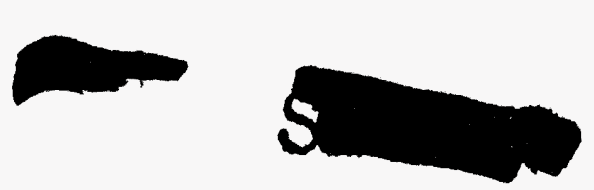

Boss Brown Suggestion

$$
\begin{aligned}
& N \text { Reactor } 4007 / \text { gear } \\
& K \text { Reactor } 2500 \mathrm{~T} / \text { yea }
\end{aligned}
$$

DECLSPIFIED

$N$ Reset on fuel

lc Reactor

$2 A W$

PAW

TRANSITION

$T A$
TOTAL

Remainctes

\begin{tabular}{ccc} 
Tors & GAL & DAYS \\
400 & - & 60 \\
2500 & - & 116 \\
- & 120,000 & 60 \\
- & 200,000 & 100 \\
- & - & 28 \\
- & - & 2 \\
\hline
\end{tabular}

366
3 comings 4 ..

0

No PAS Campinas

TRADE OFF N REACTOR OUTPUT FIR OTHER FUEL GRADE THAT WOULD BE BLENDED TI ULAPONE GRADE MATERIAL USING K REACTOR OUT PUT.

$-79-$

$-4-70$ 


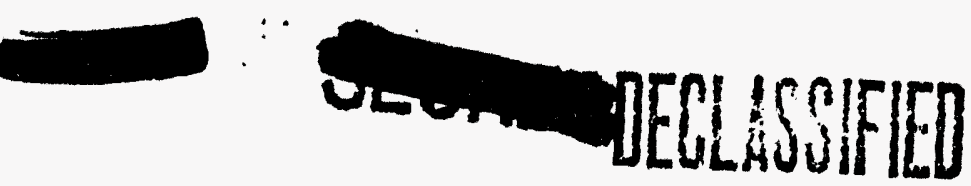

FEBRUitRY 16,1970

RNVISWED with DON LARSON B-PLANT RATES AND GLEANED THE FOLOWING:

NEW FIGURES

OLD F10

$\underline{P_{\text {RES EN T }}}$

FUTURE

$80 \quad 88(70-71)$

300

$3.30(70)$

$66(72 \$$ beyoud $)$

$260(71$ t beyoud)

$2000 \quad 2000 \quad * 2500-3000$ (7) fbeyoud)

* Imceansad Rates Depend TN EFFective solid:

REMOVAL SITHAR at PUREX OR B PLANT. DEPDENDS ON PUREX HE CENTRIFUGATION OR BARANTGETINC LARGER CENTRIFUGE. ALLSO HOOING FOR IMPRRVUEMENT

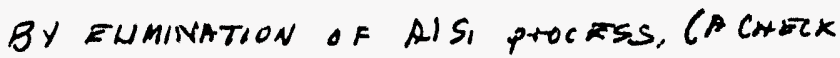
WITH WILLSRD WRIGHT INOICATES THAT SLSI PROCESS WIIl CONTINIE UNTIL AL SI COMRENENTS AXE ILLL USED. THUS WE WULA NOT SEF CHANGE UNTIL 21/2 YFARS - HOCWEAER, IT IS DOODTFUL NOW IF HOT-DIE SILE WILL BFUSED.

1300 (THS FIGURE MAY BE'MPROVEO by BETTER PQITATION-BUT FJGURE BLET WE HAVE NOW. ON 3/25 NEW DQITATION SYSTEM WILL BE READY - TEST'IN MAREH. NEW R.ATE BY $4115 / 70$, MAYOE)

PAW VOLUMES GAL

Preasuel by 7-1-71 $\frac{\text { OLOK }}{1,246,000}$

LEFT TO PRoChs] $7-1.71 \quad 2,184,000$

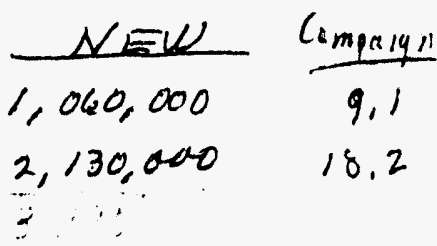

Calculates BY " RC from fallewery

Egr Teir

PROCESBES 2.1.21 24,000 1,2.48,000

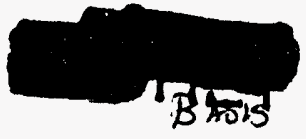

$$
\frac{26000}{50}=5,2 \mathrm{gal} / \mathrm{Tu} \mathrm{equ}
$$

$-86-$ 


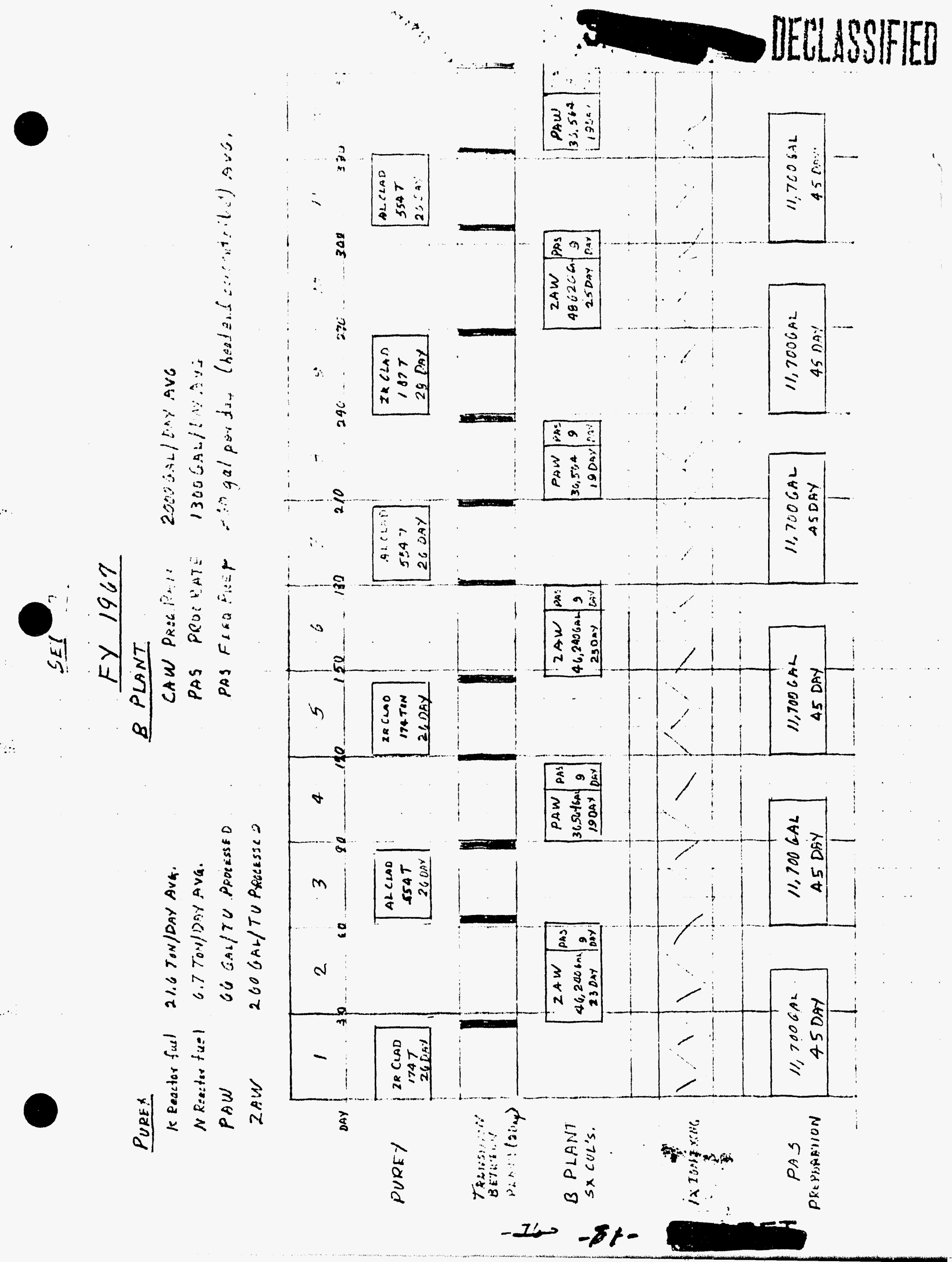




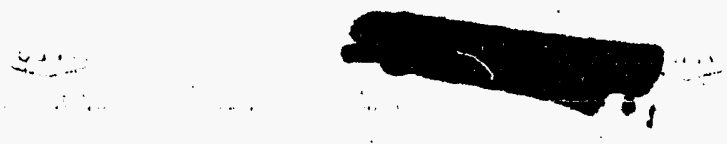

Atlantic Bicintield Hentord Company

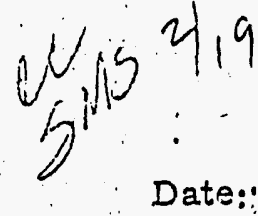

February 18, 1970

TO:

S. J. Beard

W. M. Harty

H. P. Shaw

A. E. Smith

R. E. Tomlinson

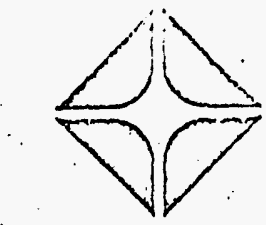

ơsß

cowk

Tiem

RES

From:

J. H. Warren

6

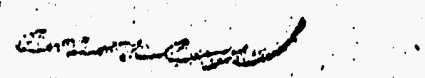

Subject:

FUTURE ACTION ITEMS

The recent discussions (February 9-10, 1970) with

F. P. Baranowski and his staff brought out several areas where we need to take action. These are listed below along with the suggested responsibility for implementation. Please let me know if there are any. questions or incorrect assignments.

1. A review of our forecasted position on in-tank solidification (essentially an updating of ARH-900, "BF oduction Schedule and In-Tank.

Sol: $\quad 2$ Alternatives, " by M J. Kirkman, G. L. and P.W. Smith). This phase of our waste munagement program should have a priority high enough to ensure operation of the three existing units at maximum boil-off rates as much of the time as possible. (SJ Beard and WM Harty)

RECEIVED

2. The development of a sequential operation case which permits unintermpted progress on siudge processing and in-tank solidification but uses the reactor storage basins for the most feasible time lag. The objective would be to allow processing in Purex with the normal sequential crew and might require basin storage equivalent to the annual output of one reactor.

(WM Harty) This, 

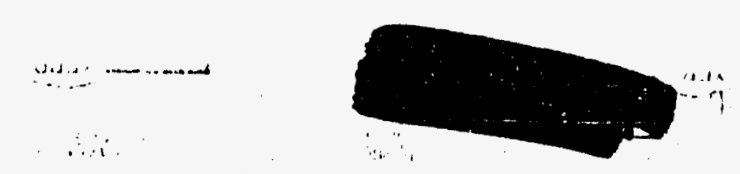

Atlantic Rlchfie!d Hanford Company

S. J. Beard, et al .

Page 2

February. 18, 1970

3. The immediate transmittal of detailed information to $F$. P. Baranowski on suspected fault lines in the 200 Areas.

(RE Tomlinson)

4. The integration of development work for the removal and transfer of salt cake to deep underground storage," with planning of programs, costs and schedules.

(HP Shaw and RE Tomlinson)

5. The development, with costs and schedules, of a deep well disposal $R \& D$ program suitable for discussion at the June budget meeting.

(RE Tomlinson)

6. The immediate transmittal of expert opinion to F. P. Baranowski on the earthquake resistance of waste tanks.

(HP Shaw)

7. An evaluation of a broad concept (suitable for discussion at the June budget meeting) which supports removal and relocation of tanked material, but not the waste material which is now stored in the soil.

(RE Tomlinson and JH Warren)

8. In-depth waste management program review to deter-

". mine if any other one to two million dollar projects are required to meet the December 31,1975 goal.

(RP Corlew's staff)

9. The latest date for adding a tank to the existing two-tank $A Z$ project without introducing a delay in their completion.

(HD Shaw) 
S. J. Beard, et al

Page 3

February 18, 1970.

10. Arrangements for the continuation of seismic studies without intermuption, if the RDT program ceases.

(P.E Tomlinson)

11. The development of data to support a policy on the use or replacement of direct buried lines.

(HP Shaw)

JHW:RWH:Sj

cc: RP Corlew

RW Harvey

ET McIntyre

LM Richards

JH Warren - 2

Central File 
Istribution

1. M. K. Harmon

2. H. H. Eopkins

3. V. R. Chapman

\begin{abstract}
Date: March 2, 1970
This document consists of

TO: M.K. Harmon

5 parges, Ho................... of

moncopies.

Fram:

V. R. Chapmát/

Subject: POSSIBILITIES FOR B PLANT - PUREX SEQUENTIAL OPERATION FROM JULY 1, 1971 THROUGH DECEMBER 31, 1974

References: I) "Future Action Itens," memo J.H. Warren to S.J. Beard, et al, dated February 18, 1970.

2) DUN-AOP RD 1 (Secret), "9-69 COPE Studies," R.W. Bown, et al, dated October 10, 1969.
\end{abstract}

Item 2 of reference 1 requests the development of a sequential operation case whlch "permlts uninterrupted progress on sludge processing but uses the reactor storage basins for the most feasible time lag." This report Is an exercise wh1ch 111 ustrates the approach that could be taken to study the feasibility of Purex - B Plant sequential starting with FY: 1972: while PAS processing 18 st1ll in progress, and to show how the inventory of the reactors' basins will increase during the three and onchalf year period under consideration.

Since we st111 do not have production forecast quality numbers avallable on which to base a study, the 9-69 COPE case 01-BX-101 (reference 2) was used as the basis for this exerclse. This particular COPE case assumes the operation of one $K$ plus $I$ reactor after June 30 , 1970 to produce blended plutonium meeting reapons speciflcations. In this case, the K Reactor plutonfum 18 produced with 5 percent Pu-240 while If Reactor plutonium Pu-240 content starts out at 7.45 percent but drops to 7.30 percent by FY 1975.

The following assumptions and tables should make clear the loglc used in this study. A table was developed for FY 1976 (the first full year in whlch no PAS will be processed) to 1Ilustrate one important point, i.e., sequential operation is not a feasible scheme on a continuing basis so long as Hanford is on an $\mathbb{N}-K$ mode unless the $\mathbb{N}$ Reactor operating program Is changed to substantialiy reduce the annual uranium throughput.
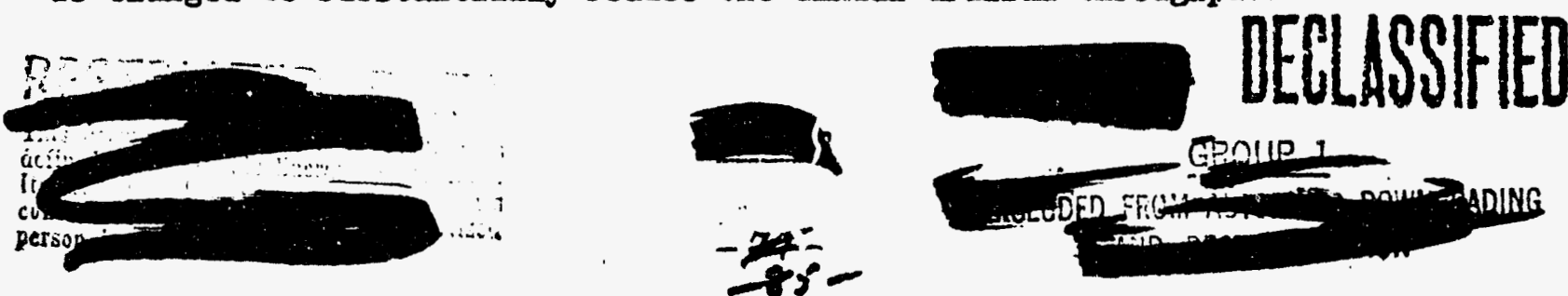
M. K. Harmon

March 2, 1970

Page 2

DEDLLSSFFED

\section{ASSUMPTIONS}

1. As of July 1, 1971, there will be the equivalent of $2,130,000$ gallons of unmined PAS feed remaining in the waste storage tanks. Since the B Plant head end treatment reduces this volume by a factor (arithmitic) of 10 , this represents 213,000 gallons of $\mathrm{SX}$ extraction battery feed.

2. Approximately 45 days will be required to mine 117,000 eallons of PAS and to reduce it to 11,700 gallons of extractlon battery feed. Th1s is the capacity of the head-end treated PAS storage tank. Thus

$$
\frac{213,000}{11,700}=18.2 \text { B Plant PAS carpalons }
$$

for the period July 1, 1971 through December 31, 1974. As a starting point for this study, the 0.2 of a PAS run was 1 gnored and the 18 campalgns remaining were distributed as follows:

\begin{tabular}{lccc} 
FY & Campalgas & $\begin{array}{c}\text { B Plant } \\
\text { Operat1ng Darg }\end{array}$ & $\begin{array}{c}\text { Mining } \\
\text { Days }\end{array}$ \\
\cline { 2 - 4 } 1972 & 5 & 45 & 225 \\
1973 & 6 & 54 & 270 \\
1974 & 5 & 45 & 225 \\
1975 (1st half) & $\frac{2}{18}$ & $\frac{18}{162}$ & $\frac{90}{810}$
\end{tabular}

3. Of the Purex process load shown in the COPE case, 77 percent is processed in this study. The remaining 23 percent of the load is accumulated in the reactor besins.

4. Purex Assumptions
2x-clad average processing rate Al-clad average processing rate ZAW waste generated PAW vaste generated CAN storage

$$
\begin{array}{rl}
6.7 & \mathrm{~T} / \mathrm{day} \\
21.6 \mathrm{~T} / \mathrm{day} \\
260 \mathrm{gal} / \mathrm{TU} \\
66 \mathrm{gal} / \mathrm{TU} \\
55,000 \mathrm{gal} / \mathrm{max}
\end{array}
$$

5. Waste Maneqement Assumptions

Mining and actdifying 117,000 gallons of PAS and bead end treatment ylelding Il,700 gallons solvent extraction feed 45 days

B Plant solvent extraction feed rates
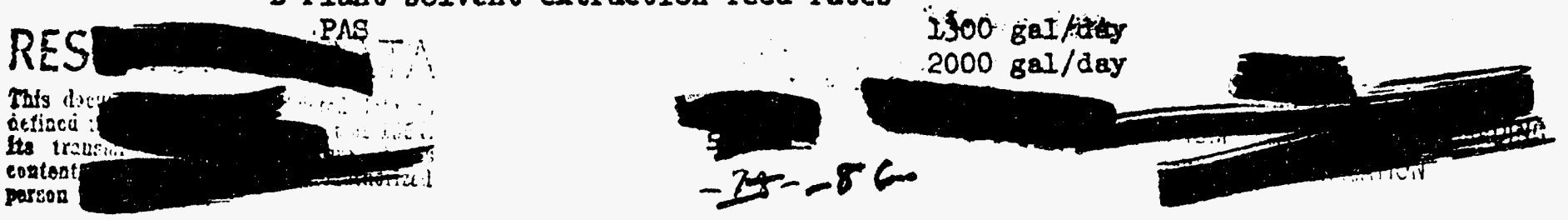
M. K. Hartion

March 2, 1970

Farge 3

6. Durex Campaiens/Year

FYs 1972,1973 and 1974

1975 , ist half

7. Purex Turnaround

For Al-clad 94 metal
$3 \mathrm{~K}, 3 \mathrm{~N}$

IK, $2 \mathrm{~N}$

8. Transition of Floating Crew between Purex and B Plant

At completion of each Purex campalen 2 days

At completion of each B Plant campalgn 2 days

\section{OPERATING SCHEME}

FY 1972

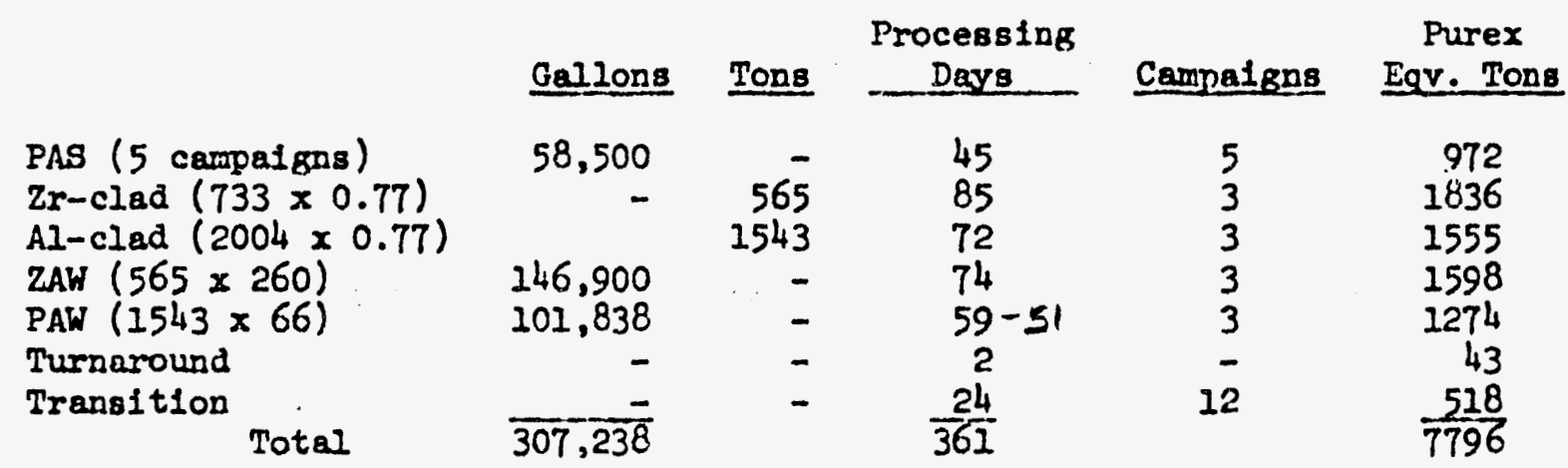

Basin Inventory Increase

375 Reactor $733-565$

$260 t$ K Reactor $2004-1543$

FY 1973

PAS (6 campaiens)

Zr-clad $(695 \times 0.77)$

Al-clad $(2195 \times 0.77)$

ZAW $(535 \times 260)$

PAW $(1662 \times 66)$

Turnaround

Transition

Total $\frac{168}{461} \frac{10}{15+7}$

$\begin{array}{rrrrr}70,200 & - & 54 & 6 & 1166 \\ - & 535 & 80 & 3 & 1728 \\ - & 1662 & 77 & 3 & 1663 \\ 139,100 & - & 70 & 3 & 1512 \\ 109,692 & - & 55 & 3 & 1188 \\ - & - & 2 & - & 1,3 \\ - & - & \frac{24}{362} & 12 & \frac{518}{7818}\end{array}$

\section{Basin Inventory Increase}

Neactor (695 - 535)

$K$ Reactor ( 2159 - I662)

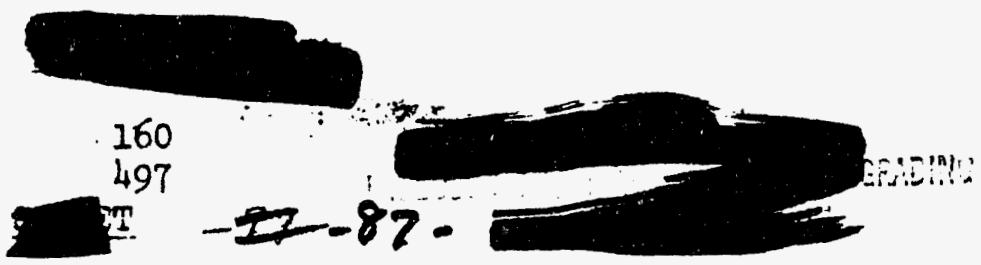




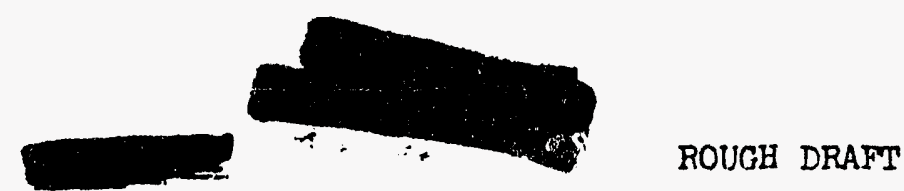

M. K. Harnon

March 2, 1970

Page 4

FY 1974

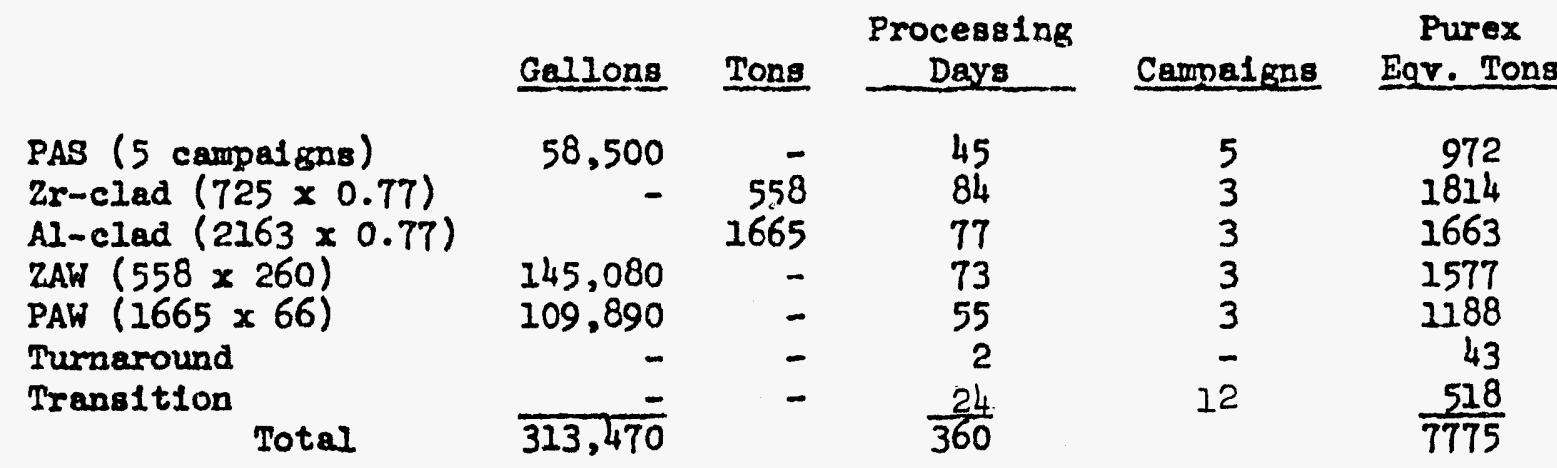

Basin Inventory Increase

Reactor $(725$ - 558)

160

K Reactor (2163 - 1665)

498

FY 1975 (18t bals)

PAS (2 campalgns)

Zr-clad ( $507 \times 0.77$ )

Al-clad $(721 \times 0.77)$

ZAW $(390 \times 260)$

PAL $(555 \times 66)$

Turnaround

Trensition

Total

$\begin{array}{rrr}23,400 & - & 18 \\ - & 390 & 58 \\ - & 555 & 26 \\ 101,400 & - & 51 \\ 36,630 & - & 19 \\ - & - & 2 \\ - & - & \frac{12}{184}\end{array}$

$2 \quad 389$

21253

1562

21101

1410

$-43$

6

$\frac{259}{40 \div 7}$

Basin Inventory Increase

1) Reactor $(761 / 2-390)$

(10)

IR Reactor (2173/2 - 555)

531

Basin Inventory Busladup

I Reactor $\mathrm{K}$ Reactor

COPE 12-31-74 inventory estimate

499

168

160

FI 1973 busldup

FY 1974 butldup

One-half FY 1975 bulldup

Study 12-31-74 Inventory
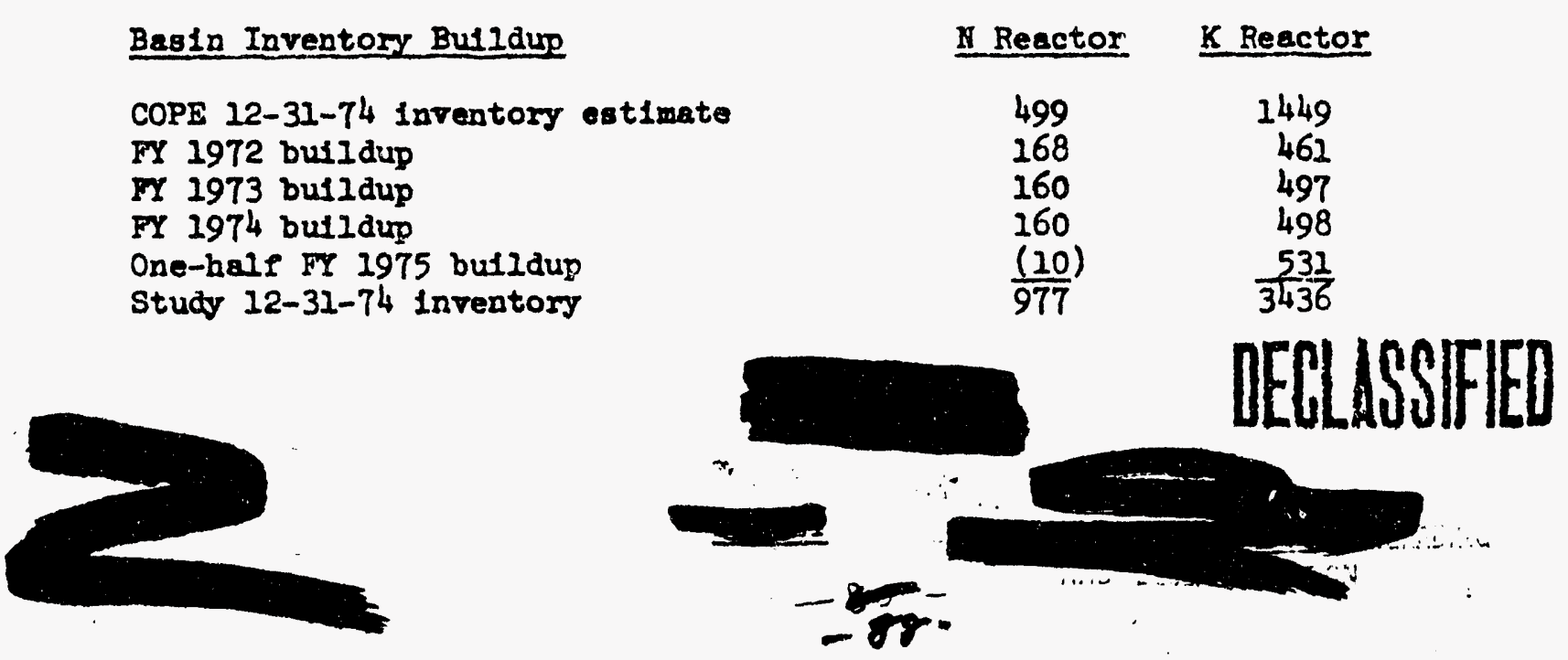


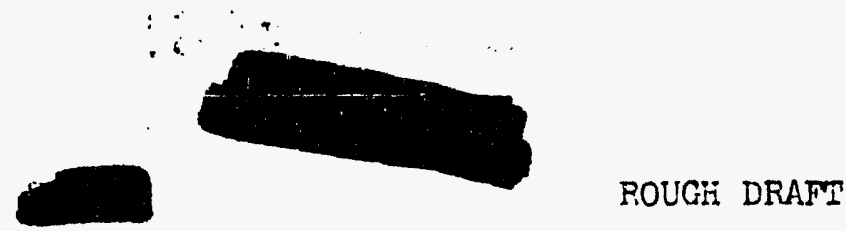

M. K. Harmon

March 2, 1970

Page 5

\section{FY 1976}

\begin{tabular}{|c|c|c|c|c|c|}
\hline & Gallons & Sons & $\begin{array}{c}\text { Processing } \\
\text { Days }\end{array}$ & Campaigns & $\begin{array}{c}\text { Purex } \\
\text { Egv. Tons }\end{array}$ \\
\hline PAS & 0 & - & 0 & 0 & 0 \\
\hline $\mathrm{Zr}$-clad & - & 791 & 118 & 4 & 2549 \\
\hline Al-clad & - & 2173 & 101 & 4 & 2182 \\
\hline ZAW $(791 \times 260)$ & 205,660 & - & 103 & 4 & 2225 \\
\hline PAH $(2173 \times 66)$ & 143,418 & - & 72 & 4 & 1555 \\
\hline Turnaround & - & - & 2 & - & 43 \\
\hline $\begin{array}{l}\text { Transition Total } \\
\text { Tot }\end{array}$ & $\frac{-}{349.078}$ & - & $\frac{32}{428}$ & 16 & $\frac{691}{9245}$ \\
\hline
\end{tabular}

Note: Reactor output for FY 1976 would have to be reduced about 2 percent before the annual output from one $K$ and $N$ reactors under COPE case 01-BX-101 would fit a Purex - B Plant sequential mode. This gives no capacity to reduce the basin inventory buildup which occurred over the course of the previous four years.

VRC : mkl
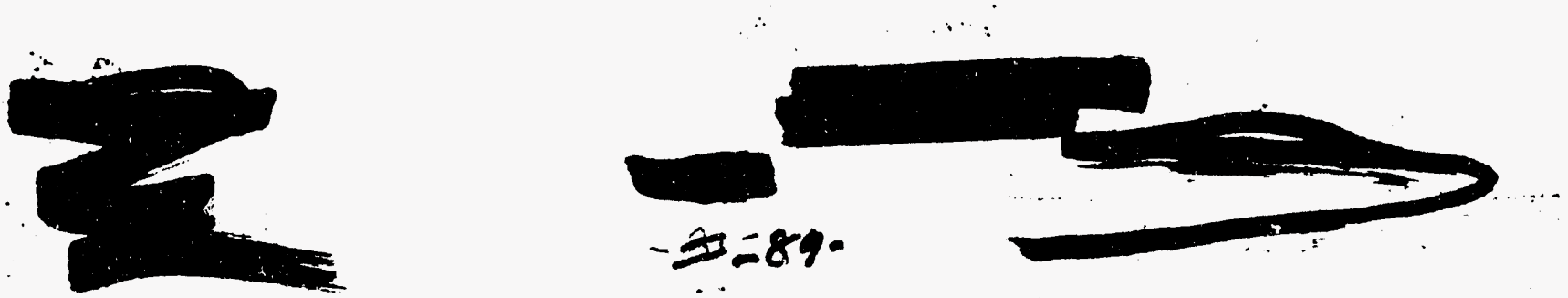


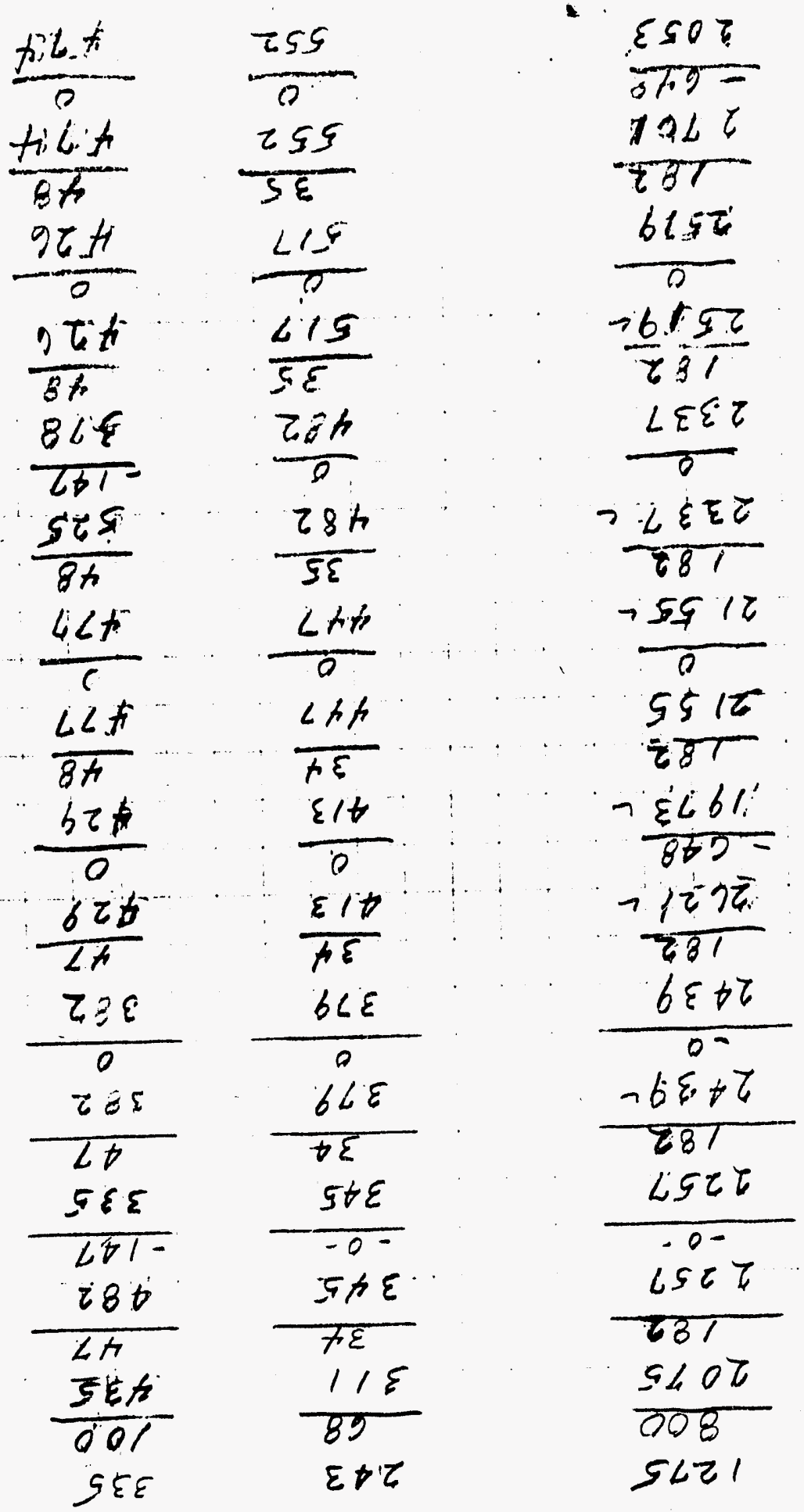

$\overline{60 \text { OU77.8Z }} \overline{060477-76} \overline{\text { X्र०N } 8672-76}$

$$
\begin{aligned}
& \text { कराP रुप0 }
\end{aligned}
$$

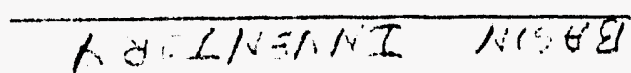

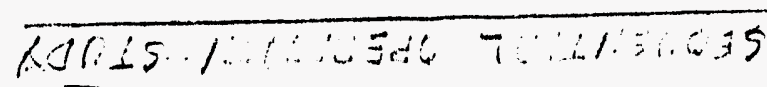

: IJ

ZLWUS

I

$\exists \forall \wedge^{\prime}$

$1 \exists$

16,738

$\tau$

IUN

$1 \exists$

$1 \angle \operatorname{MON}$

$I$

$I \forall N$

13

12100

I

$\exists \forall N$

IE

$l, d \equiv S$

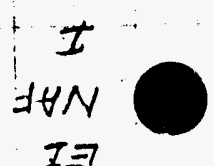

$1 / \cap \cap t$

$I$

$D+N$

ANI UNZ

oodd 12 , iIn

$\Rightarrow$ पहाकपाषमt।

$0 \Rightarrow \exists=0 \div 0$ 바에

ANIN⿴囗十马 $/ L-1-L$

वзDस

DNID\& $1 L-1-L$

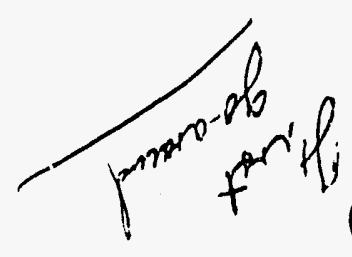


AL CLADNOR

$$
\begin{aligned}
& \text { EI } \\
& \text { NAF } \\
& \text { I } \\
& \text { FEB } 72 \\
& \text { EI } \\
& \text { NAF } \\
& \text { I }
\end{aligned}
$$

MIAR 72

E)

NAF

$I$

APRTL

EI

NAF

I

MaY 72

EI

NAF

I

- E

$\begin{array}{r}2053 \\ \frac{162}{22352} \\ \hline 20 \\ \hline 2235\end{array}$

$\frac{192}{2417}$

$\frac{n}{2417}$

$\frac{182}{2599}$
$\frac{0}{2592}$
$\frac{182}{2781}$

$\frac{-324}{2459}$

$\frac{183}{26405}$
JUN 72

$-2-$

$\frac{\frac{0}{2640}}{\frac{182}{2822}=}$

SEP72

E)

NAF

$I$

OCT72

EI

$\frac{1.2}{2720}$
A+L-CLAD

$\frac{0}{2822}$
$\frac{182}{3004}$
$\frac{0}{3004}$
$\frac{182}{3186}$

20.624094

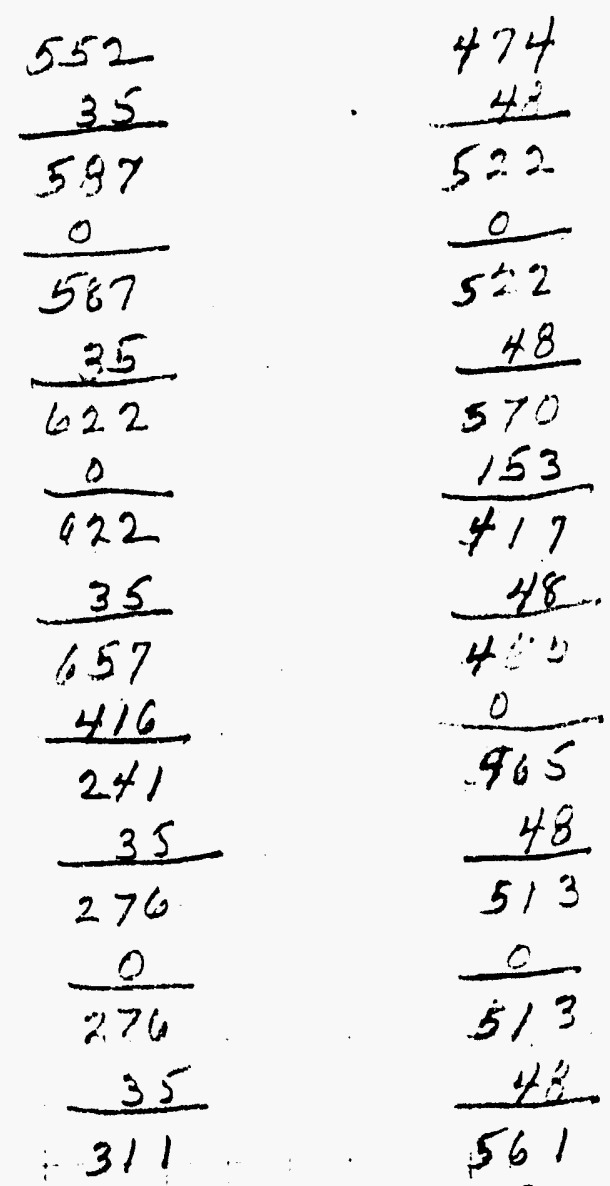

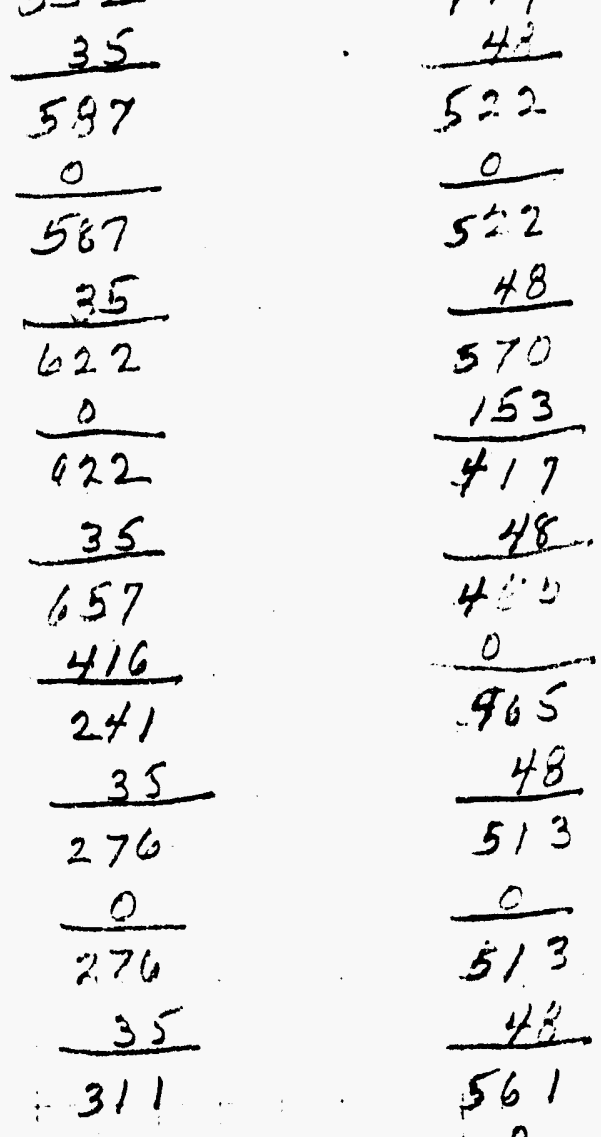

$\frac{\frac{0}{311}-\frac{0}{561}-\frac{47}{345}-\frac{408}{-647}-\cdots \frac{10}{40}}{-\frac{34}{441}}$

$\frac{0}{3 \% 5} \quad \frac{-147}{\$ 461}$

\begin{tabular}{c}
34 \\
379 \\
0 \\
\hline 379 \\
34 \\
413 \\
0 \\
413
\end{tabular}

$\frac{47}{508}$
$\frac{0}{508}$

$\frac{47}{555}$

$\frac{648}{2538}$

$\begin{array}{ll}\frac{3}{447} & \frac{49}{6.33} \\ \frac{0}{447} & \frac{0}{603}\end{array}$

$\frac{0}{555}$

$\frac{0}{2720}$

DERILSSIFIED 
$-1$

NAF

I

Nov 72

EI

NAF

$I$

DEC 72

EI

NAF

$I$

JAN 73

EI

NAF

$I$

FEB $>3$

Ẽ.

NAF

$I$

MAR73.

E.

NAF

$\tau$

APR 73

E.I

NAF

$I$

MAY 73

EI

NAF:

$I$

JUN 73

EI - - -

$I$

JUL.73

51
2720

182

$2903^{2}$

$\frac{0}{2902}$

$\frac{162}{3084}$

$\frac{0}{3084}$

$\frac{182}{3266}$

$-643$

26184

182

$2800-$

$\frac{0}{2800 \mathrm{C}}$

152

$2982=$

$\frac{0}{2982}$

$\frac{182}{3645}$

$\frac{0}{5764-}$

$-182$

$3342-$

$\frac{-324}{3022}$

$\frac{183}{320.5}$

320.5

$\frac{0}{320^{\prime} \overline{9}}$

$320: 5$

$\frac{182}{31872}$

$\frac{10}{3387}$
4 ष

35

482

$\frac{0}{1182}$

$\frac{35}{51.7}$

$\frac{0}{i 1 \%}$

$\frac{35}{552}$

-

1) 52

$\frac{35}{587}$

$\frac{0}{527}$

$\frac{35}{622}$

$\frac{0}{\cos 2}$

$\frac{35}{657}$

$\frac{416}{241}$

$\frac{35}{276}$

276

$\frac{0}{276}$

$\frac{35}{319}$

0

311

$\frac{34}{3125}$

$\frac{0}{345}$ $\frac{603}{48}$

$\frac{147}{504}$

$\frac{48}{552}$

$\frac{0}{5: 2}$

$\frac{78}{500}$

500

$\frac{48}{148}$

$\frac{0}{6.18}$

$\frac{48}{698}$

$\frac{-153}{1513}$

5.3

$\begin{array}{r}48 \\ \hline\end{array}$

$69 \%$

$\frac{0}{59 \%}$

48

0.39

$\frac{0}{639}$

$\frac{48}{6.87}$

$\frac{0}{689}-\ldots$

$\frac{47}{134}$

$\frac{147}{58.7}$ 
EI

NAT

I

Aug 73

EI

NAF.

I

SEP'?

EI

NAF

$I$

OC.T 73

EI

NAF

I

Nov 73

E.I

NAF

$I$

DeC 73

EI

NAF

$I$.

$\operatorname{TAN}^{\prime} 74$

EI

NAF

$I$

FEO3 74

El

NAF

$I$,

Mar 74

EI

NAF

I.

APR' 74

EI $\therefore \angle A O N O R$

3387

$\frac{192}{35692}$

$\frac{2}{35692}$

$\frac{182}{3751}$

$-648$

$3103=$

$182^{\prime}$

$3285-$

$\frac{0}{3285}$

$\frac{152}{3+6.12}$

$\frac{0}{3467}$

$\frac{182}{3649}$

$\frac{0}{3649}$

$\frac{182}{383 \pi}$

$\frac{648}{3183}$

182

3365

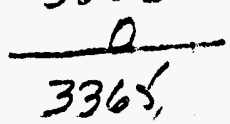

$\frac{182}{35 \times 7}$

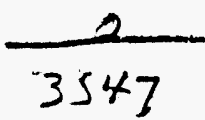

182

3729

i)

3729
$3+5$

$\frac{34}{379}$

399

$\frac{34}{413}$

$\frac{0}{413}$

$\frac{34}{447}$

$\frac{0}{417}$

$\frac{35}{48 \%}$

$\frac{6}{412}$

$\frac{35}{517}$

$\frac{0}{51.7}$

$\frac{35}{552}$

$\frac{0}{552}$

$\frac{35}{58 \%}$

$\frac{0}{5.57}$

$\frac{35}{\therefore 2}$

$\frac{0}{62.2}$

$\frac{35}{6.57}$

46

241

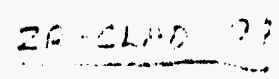

$58 \%$

$\frac{41}{1.3 \frac{21}{1}}$

$\frac{0}{34 \%}$
$\frac{41}{58}$
$\frac{61}{481}$

$\frac{48}{729}$

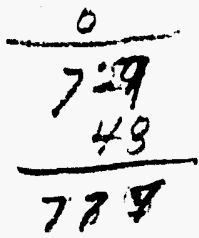

$\frac{-147}{630}$

$\frac{48}{678}$

$\frac{0}{178}$

$\frac{48}{726}$

$\frac{0}{726}$

$\frac{48}{774}$

$\frac{0}{172}$

$\frac{48}{827}$

$\frac{153}{469}$

$-\frac{48}{7.17}$

$\frac{0}{317}$

DECLASSIFIED 
AL.CLADNER AL-6_ADS-

$2 R-C L A D O A$

EI

NAF

I

MaY' 74

EI

NAF

$I$

JUN it

E.

NAF

$I$

JUL'Ty

EI

NAF

$I$

A.ve 74

E. 1

NAF

$I$

SEP 74

EI

NAF

$I$

OCT. 74

EI

NAF

$I$

Nov 74f

EI

NAF

$I$

DEC 74

NAF

$\frac{I}{J_{A S T}} \div 5$

$\bar{E}$

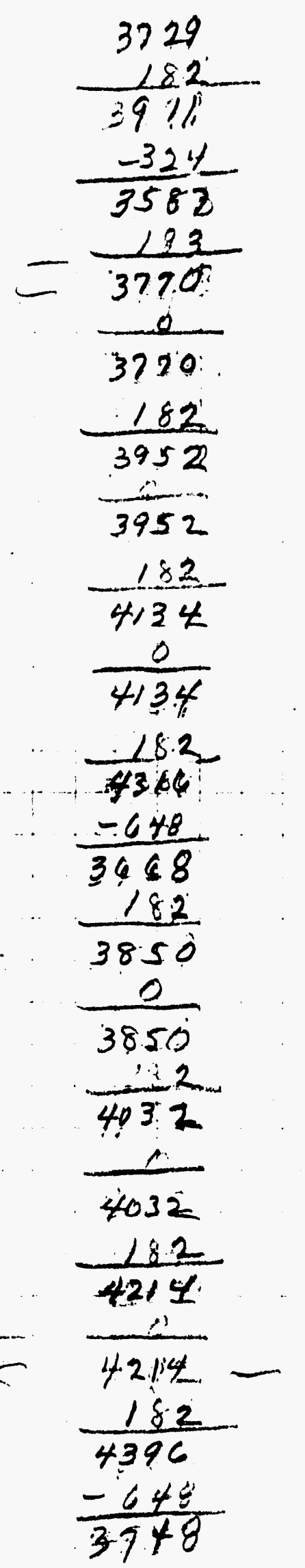

241
35
276
0
276

35

311

$\frac{0}{11}$

7).

$\frac{48}{365}$

$\frac{34}{345}$

- a

345

$\frac{3 x}{39}$

379

379

$\frac{10}{765}$

$\frac{48}{813}$

$\frac{0}{8^{3} / 13}$

$\frac{47}{560}$

$\frac{147}{713}$

$\frac{47}{760}$

$\frac{0}{60}$

$\frac{34}{483}$

$\frac{47}{8.08}$

$\frac{n}{4 / 3}$.

$\frac{34}{147}$

$\frac{0}{447}$

$\frac{75}{4.82}$

$\frac{0}{452}$

$\frac{35}{517}$

0

$80 \%$

48

855

$\frac{0}{85.5}$

$\frac{4-8}{903}$

$\frac{147}{256}$

$\frac{48}{54}$

$\frac{0}{5 / 17}=$

$\frac{0}{004}=$

$\frac{35}{52}$

$\frac{48}{852}$

$\frac{0}{532}$

352 


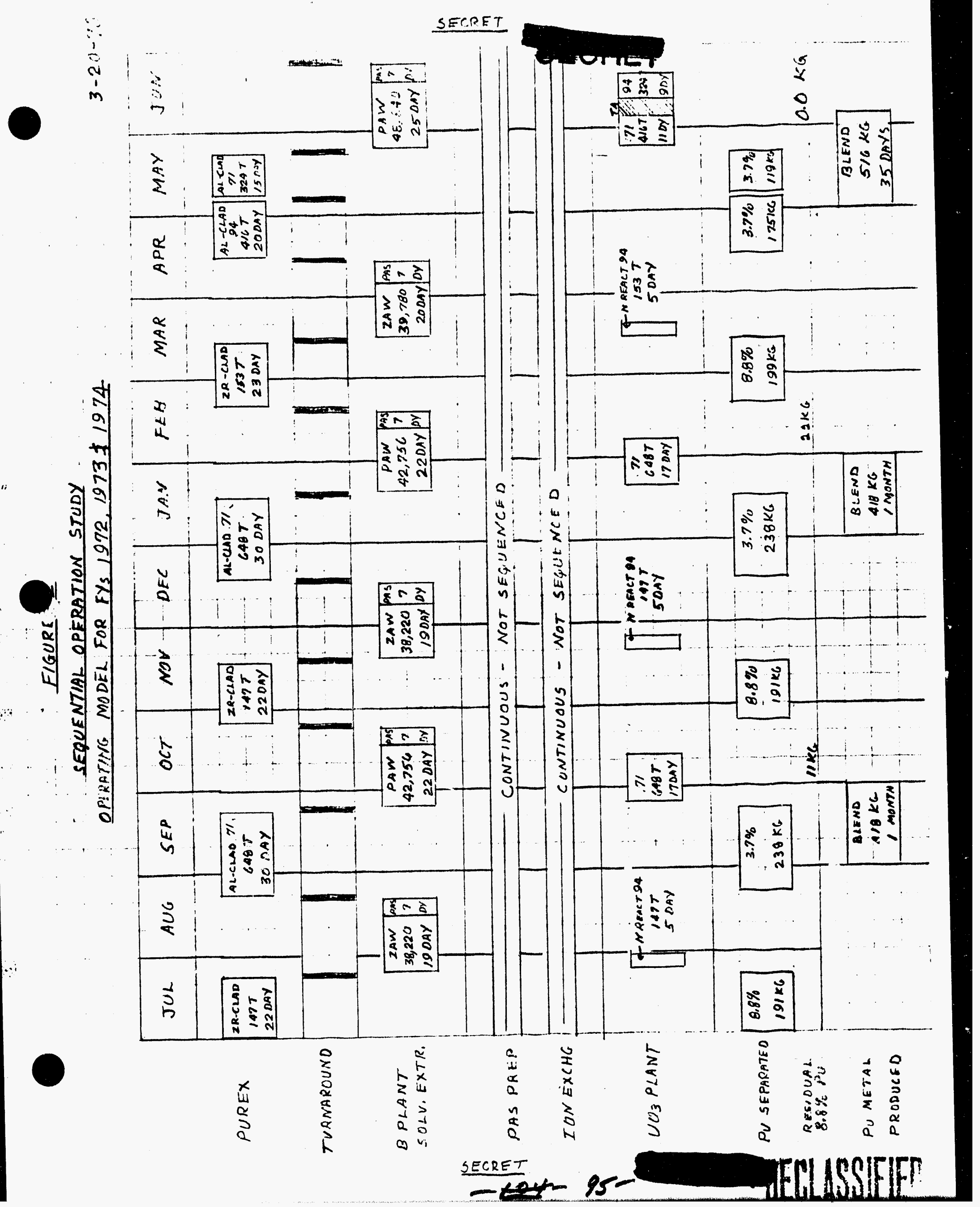




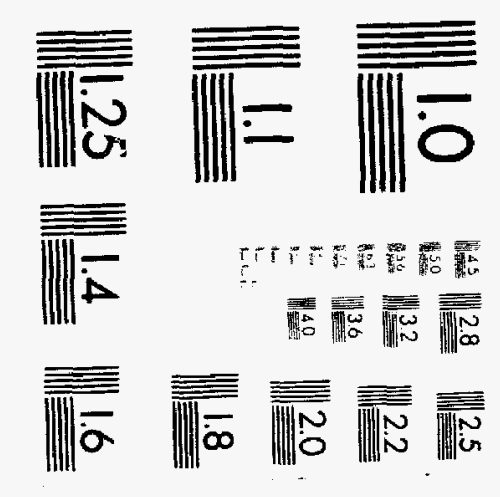



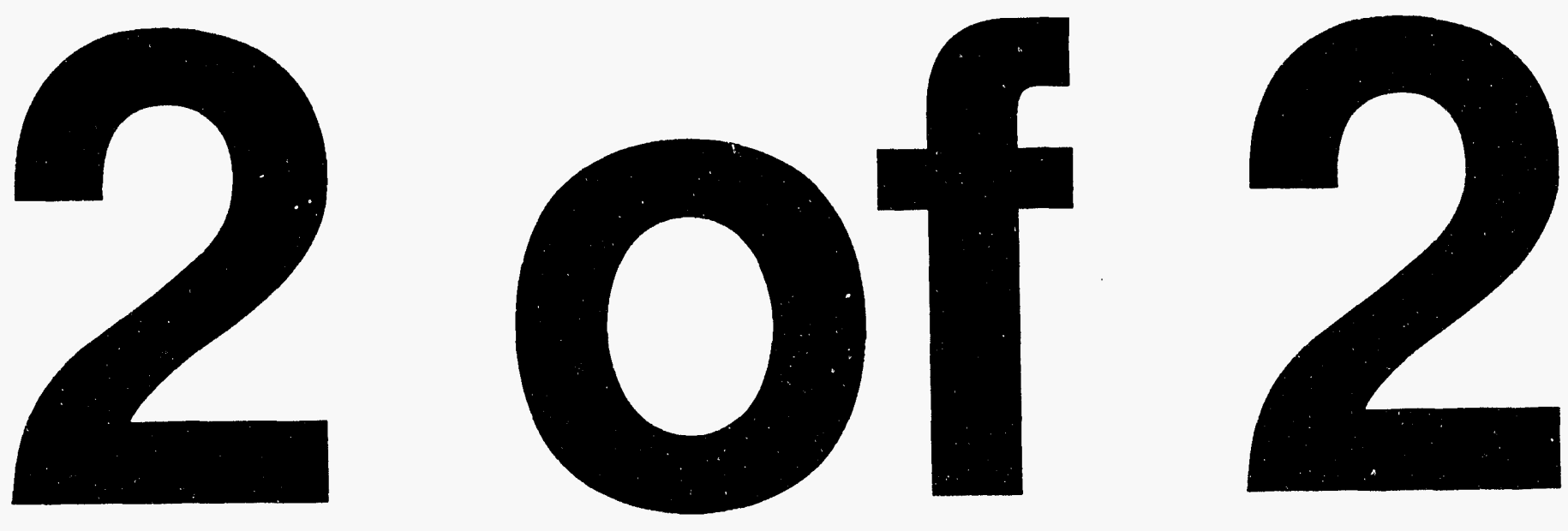


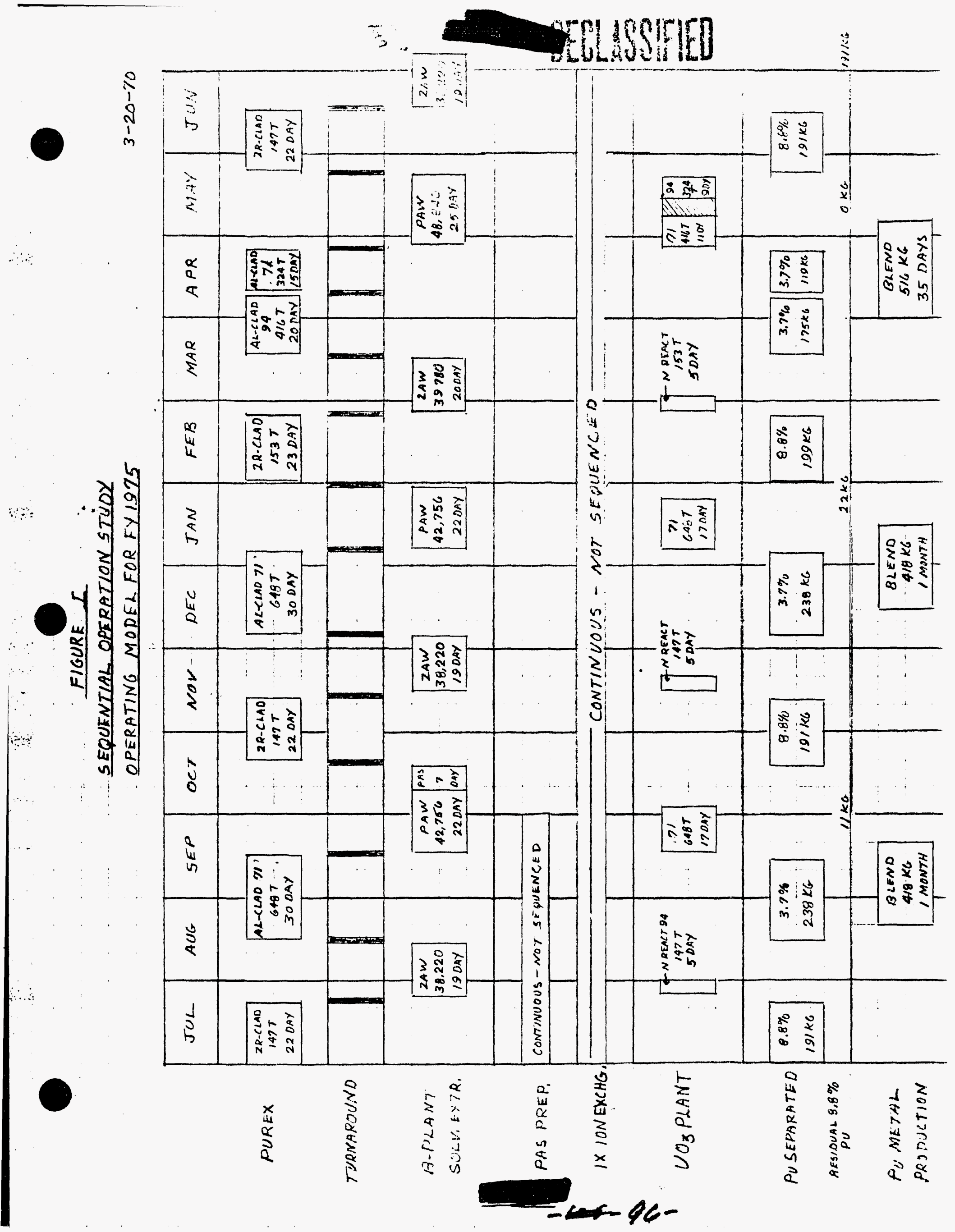



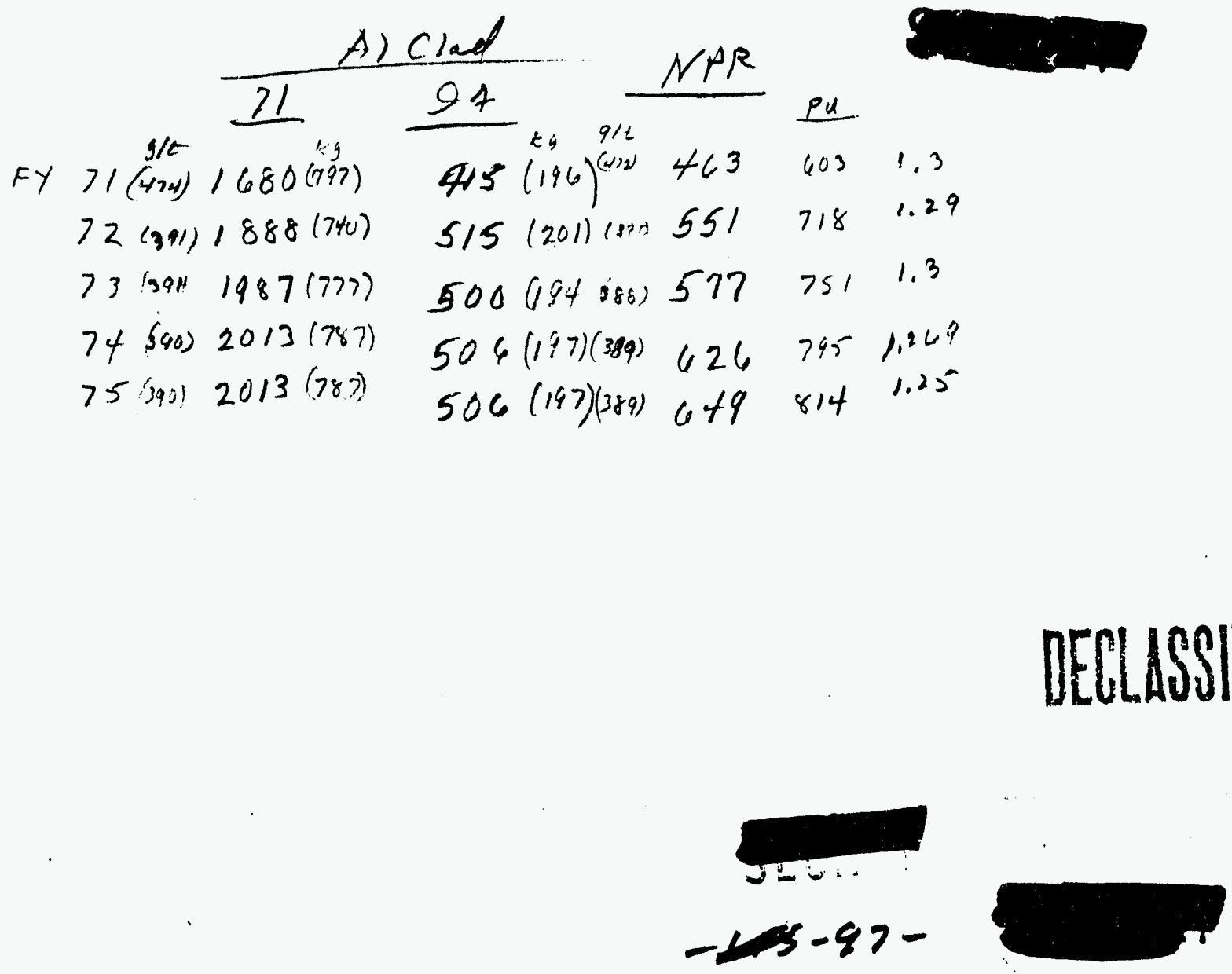


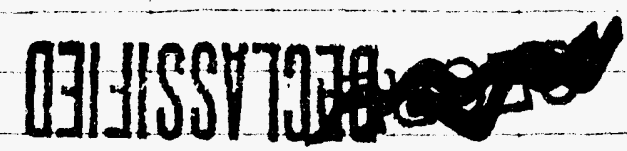

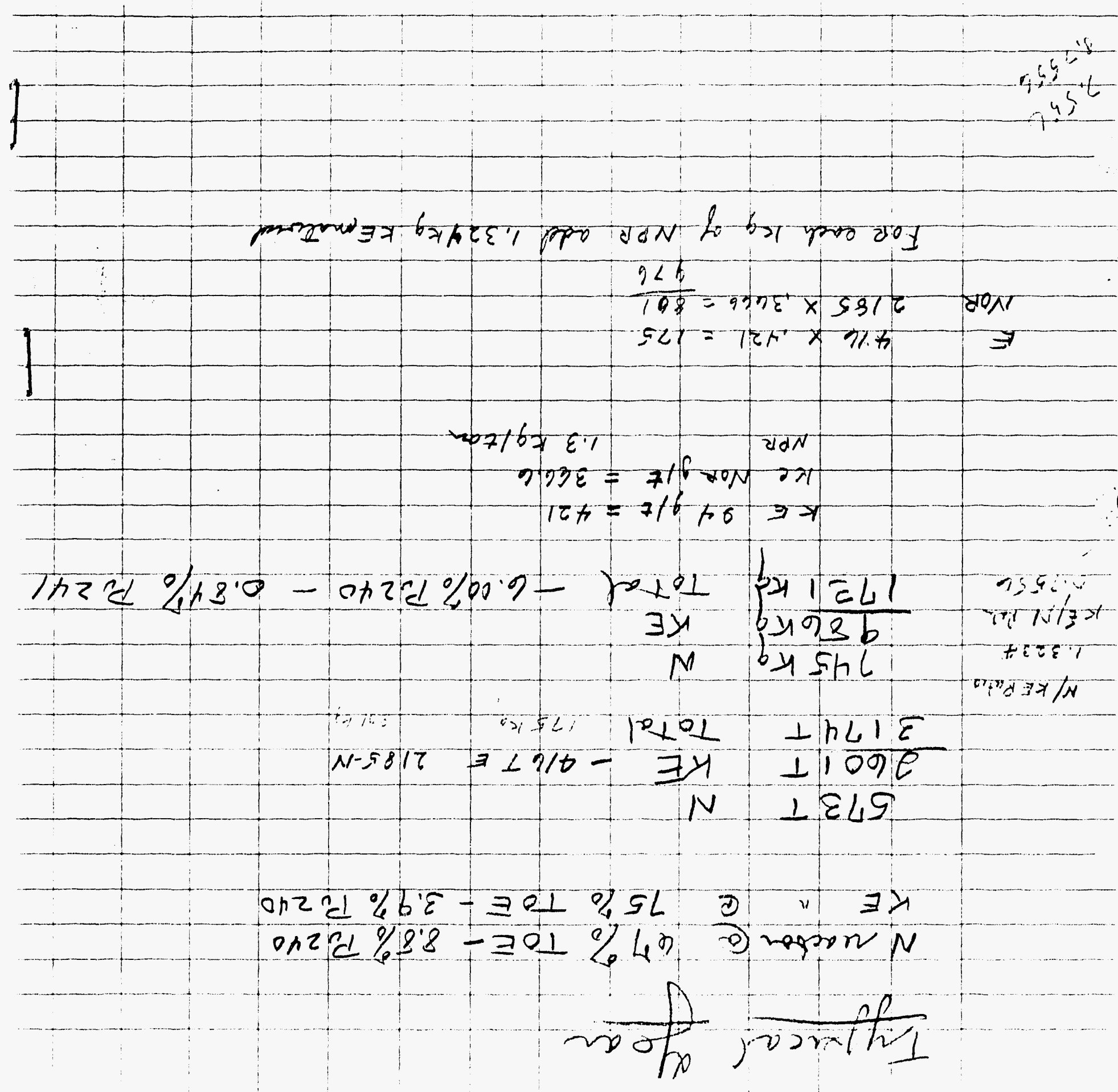


GIRICTYY PRIVATE

Date: $\quad$ March 10, 1970

To: 0. P. Beaulleu

J. D. NeIntosh

o. V. Smiset

From: V. R. Chapman

Subject: SEQUEHTIAL OPERATIOH STUDY

Attached is the outline 4. K. Harmon used yesterday when ho discussed with us the accomplishments expected from our task force.

I am sure that the word vill jet about $300 n$ that the task force is studyine sequential operations. However, task force is studyinc sequential opting would serve to ruel suwors that are already Iloatine about "STRICTLI PRIVATE."

VRC: mkl

ce: VR Chapman

Enclosure 


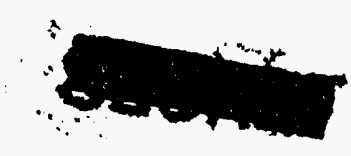

SEQUENTIAL OPERATTON STUDY - MANUFACTURING, PHASE I

2. SaTe $\mathrm{KEE}$

a. By showng 200 Areas alternative and cost reduction

2. Bases

Q. B Plant and Waste Manegement operations will control

b. Purex to run as much as possible within Ilants imposed by $A R$ vault, etc.

c. Waste Management "6oals" to be met (end CY 75)

d. "Hicess" reactor production to be held in basins

e. Schese to be operational July, 1972

f. Use D. KCDonald numbers (FY 73 or 74 ) Kn9 percent; $\mathrm{X} \sim 4$ percent.

3. Schedule - Phase I

a. Ley out operating "model": by

b. Set up chemlcal operations staffing: by

c. Integrate malntenance, $\mathrm{BM}$, analutical staff1ng: by

d. Integrate McCoy, DeJong, Cunningham: by

4. 8chedule - Phase II

a. Integrate with Plutonium Finfshing: by

b. Integrate of th DUH: by

c. Establ1sh budget base and Integrate Fance: by

d. Cosplete package

$3-9-70$ 



\section{FROM DMCD FORECAE $0, \therefore A N A \cdots$}

TYPICAL YEAR

$$
\begin{aligned}
& N \text { Reactor @ 67\% TOE - } 8.8 \% \text { Pu-240 } \\
& \text { KE Reuctor@ } 05 \% \text { TOE - 3.9\% Pu-210 } \\
& \text { Nor Al.Cled } \frac{U}{2185 \mathrm{~T}} \frac{\mathrm{Pu}}{801 \mathrm{~kg}} \\
& 94 \mathrm{Alclad} \quad 416 \mathrm{~T} \quad 175 \mathrm{~kg} \\
& 94 \mathrm{zr} \text {-clad } \quad 573 \mathrm{~T} \quad 745 \mathrm{~kg} \\
& \left(\begin{array}{lll}
K E & \text { I4 } & 421 \mathrm{~g} / \mathrm{T} \\
K E \text { NOR } & 3 G G .6 \mathrm{~g} / \mathrm{C}
\end{array}\right) \\
& \text { NPE } 1300 \mathrm{~g} / \mathrm{t}
\end{aligned}
$$

THE PLANT LOAD FPOM THE A BOVE FORECAST

$$
\begin{aligned}
& \text { CAMPAIGNS TONS DAYS PU } \\
& \text { PAS. } 6 \text { - } 54 \text {. } \\
& \text { NOR ALCLAD } \quad 3 \quad 2185 \quad 102 \quad 801 \\
& 94 \text { ALCCLAD . 1 . } 416 \quad 20 \quad 175 \\
& 942 R-C L A D+3 \ldots, 573,86 \quad 745 \\
& \text { PAw-nke 144210jal } 3 \quad-12
\end{aligned}
$$

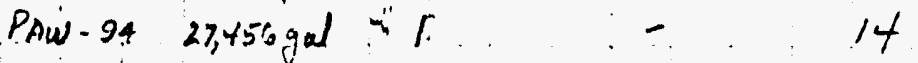

$$
\begin{aligned}
& \text {. } 2 A \mathrm{~W}: 148,980 \mathrm{gal} .3 \ldots \ldots .75 \\
& \text { TA } 14 \text { sogouch : - } 28 \\
& \text { TOTAL } \\
& 451 \\
& \begin{array}{rrr}
451 & 451 & 360 \\
82 & -582 \\
\hline 369 & \frac{28}{109} & -24 \\
\hline 282
\end{array} \\
& 36 \% \\
& \frac{282}{87} \\
& 3 6 4 \longdiv { 8 7 0 } 2 3 \\
& \frac{77 \pi}{120}
\end{aligned}
$$

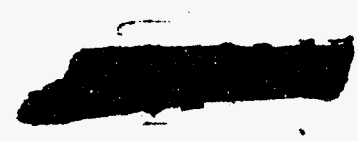




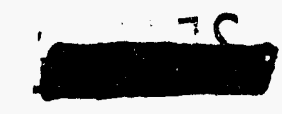

\section{O31HSSO7370}

$\rightarrow \because 20$

58\% $75 \varepsilon$

$-\frac{\tau l}{5}$

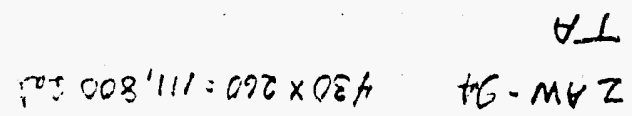

$\overline{216}-\overline{62}$

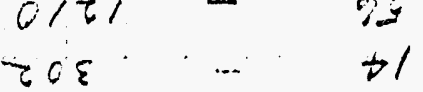

$1011 \quad-\quad$ is

$-$

- (1) $25+26=79 \times 917$

$\$ 6-M \forall c^{\prime}$

troth 655 50

$-$

$740904101=97 \times 1$ thI $\quad$ CON-MEC'

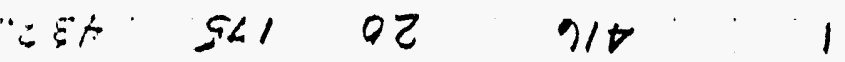

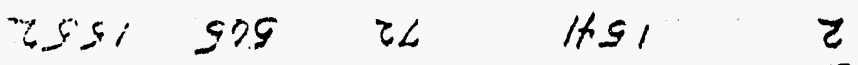

:iti - h5 -

SLCSELS OHYJ-aZ 66

$\varepsilon$

$0 \forall 13-7 \forall+6$

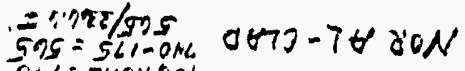

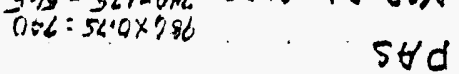

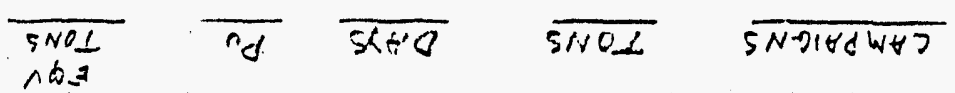

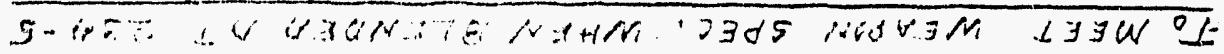

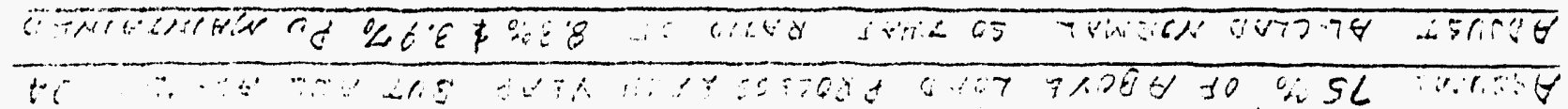




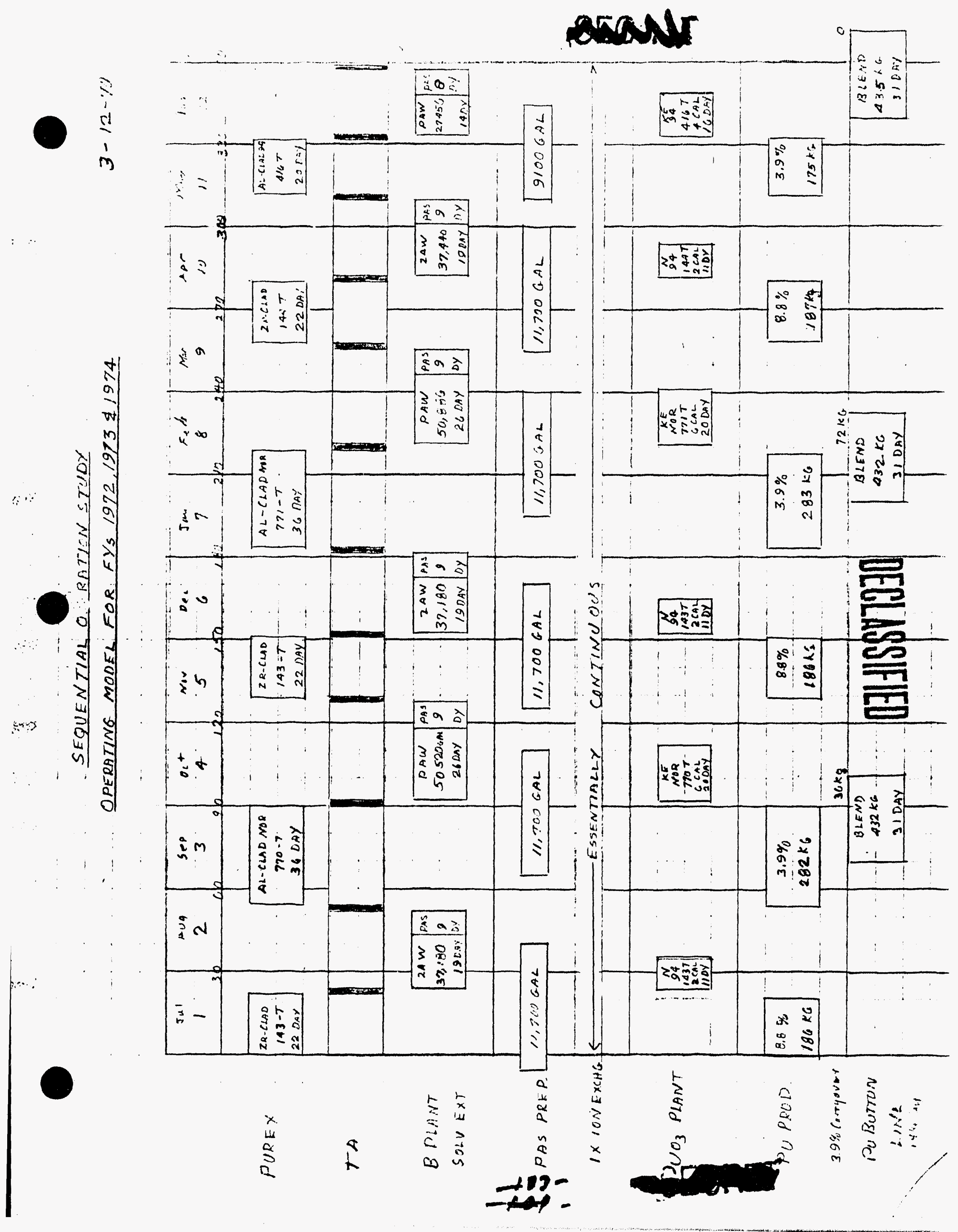




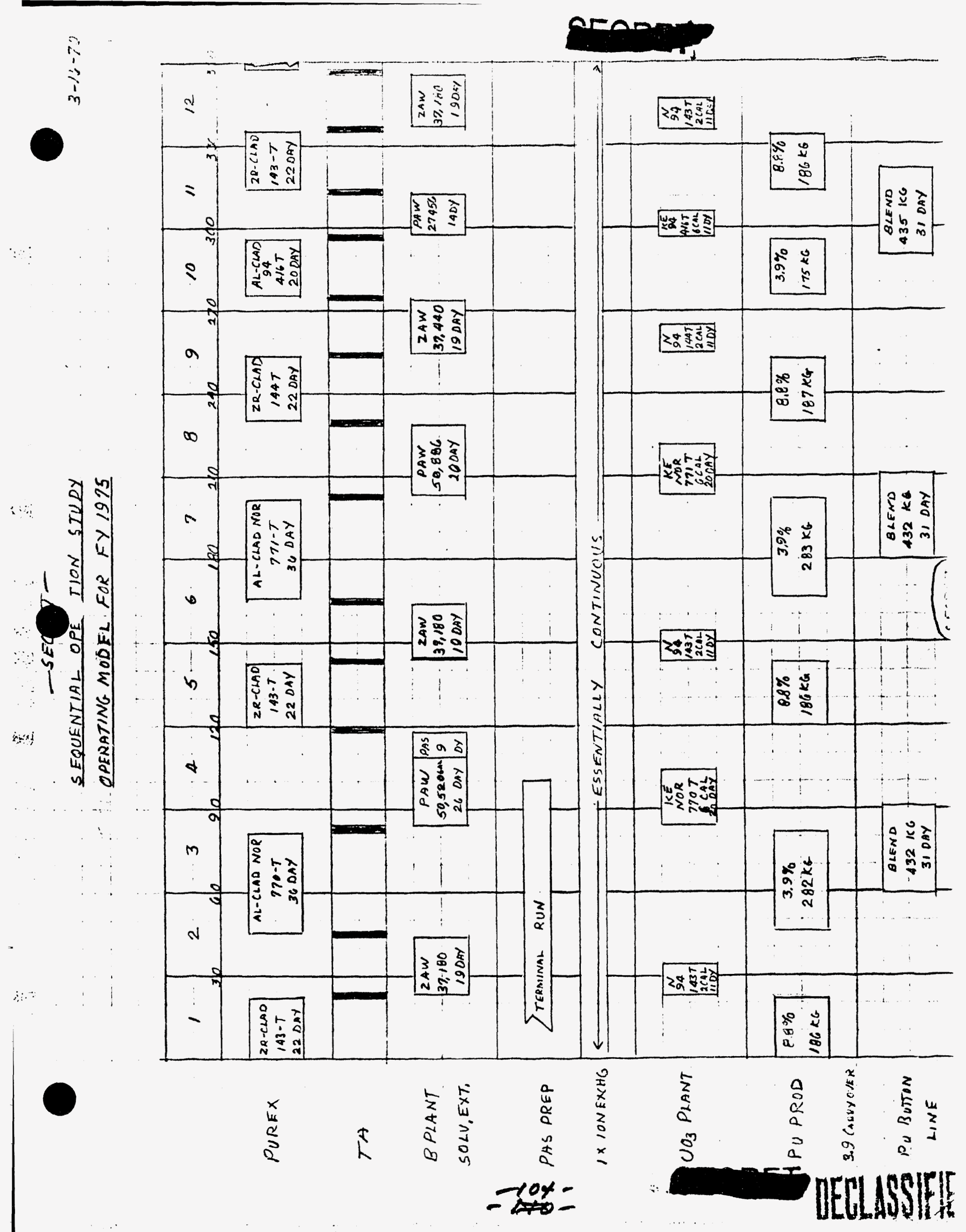




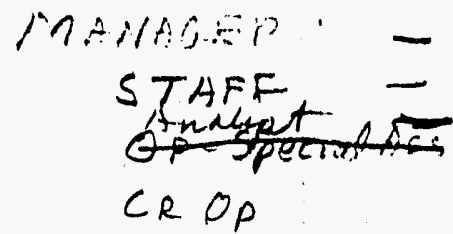

Secvetarn

$\frac{\text { Janitar }}{\text { Trach }}$

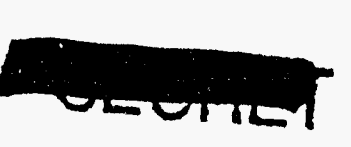

3ㄴ $4=$

$\frac{-4}{3} \frac{8}{3}, 39$

$\frac{34}{30} 36$

Aequene creal
t Preg Pexmel
Onet

108

Pomer 6

Ob+tal !

Pemaft

act hod?

my 1

ank I

B Plant

fhe 8

cane 6

21

Pmer of

Otemer 1

Lee '

nor 1

$\mathrm{NO}_{3}$

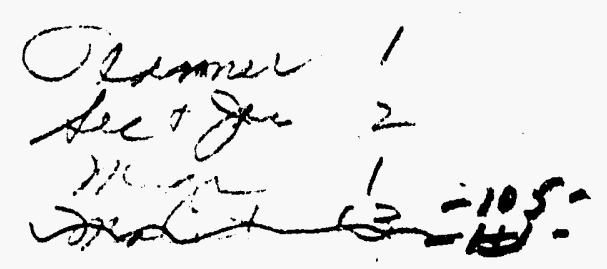

DECLASSFEED

$-28$

$\frac{111}{2198}$

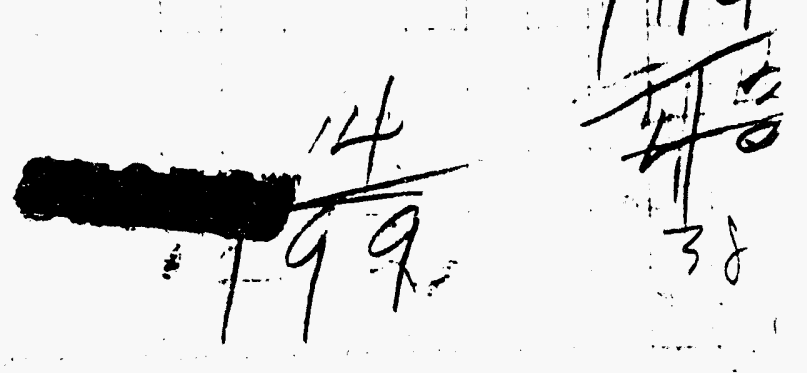




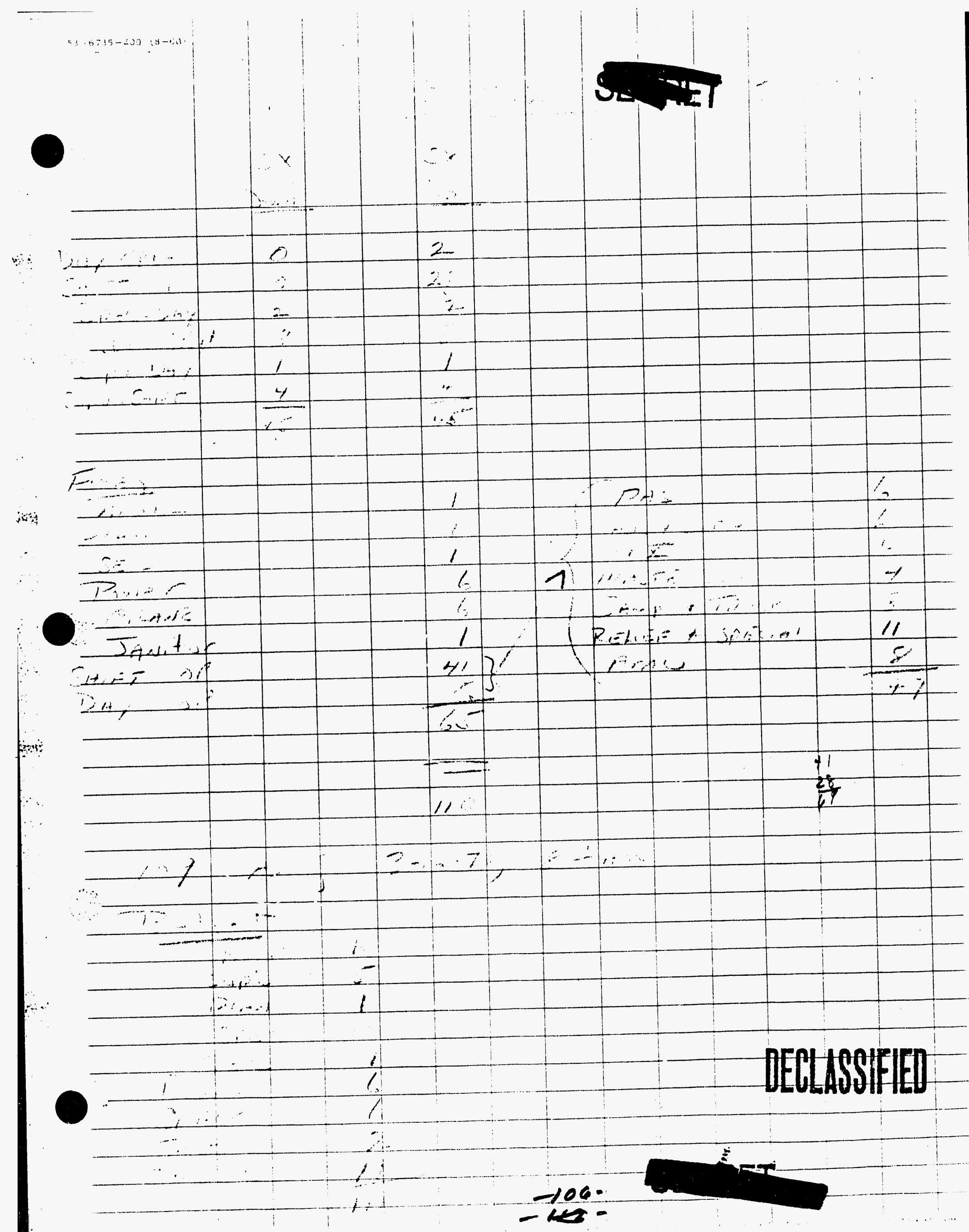


20 88

$72 \ldots 6 \mathrm{gpt}$

CH

$$
\begin{aligned}
& \text { Alciod F-70,71.8960i/TU }
\end{aligned}
$$

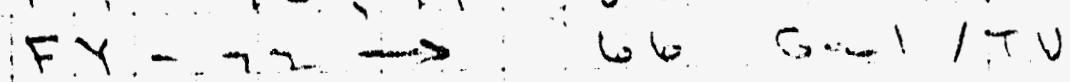

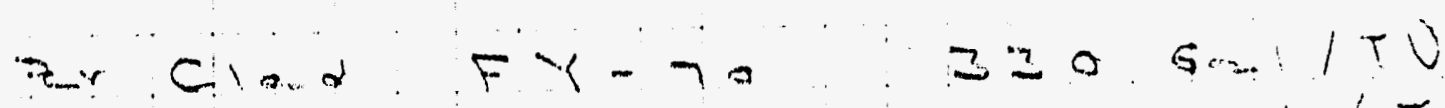

$$
\begin{aligned}
& F Y-7,1 \rightarrow 260.6 \times 1 / 2
\end{aligned}
$$

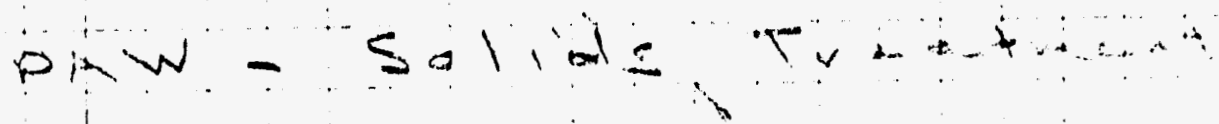

$$
\begin{aligned}
& F Y-71 \quad z 500-3000 \% \text { r p } / 2 y
\end{aligned}
$$

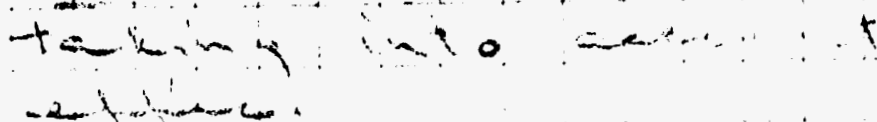

- PAST:? Duet $A$ aid t I
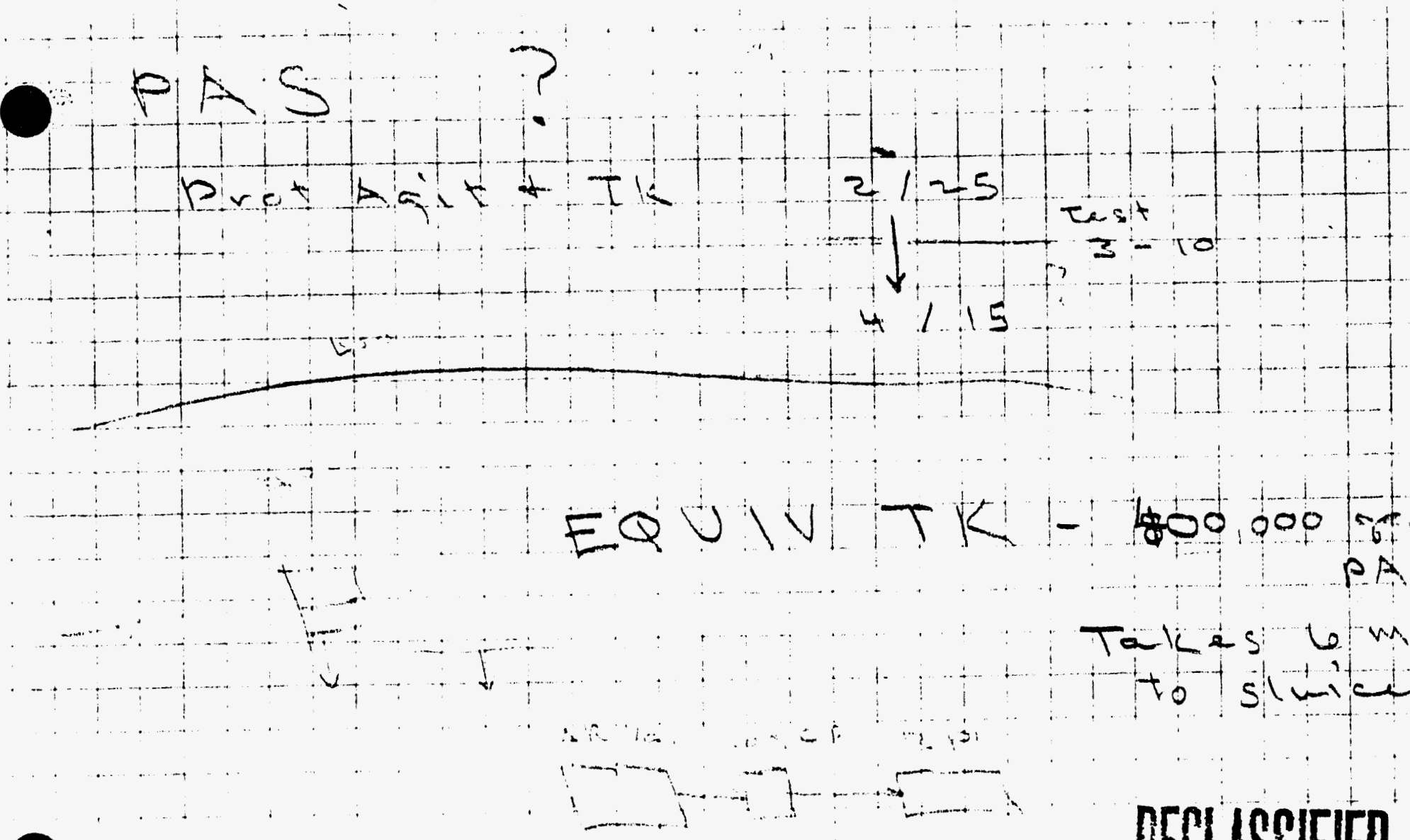

$$
\begin{gathered}
\text { Takes lom } \\
\text { to sluma }
\end{gathered}
$$

RECLISSFFIED

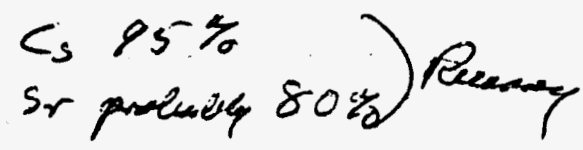


Dete: $\quad$ April 9, 1970

To: R. E. Roberts

From: Alex smith ciliy finueto

Subject: SERUENTIAL OPERATION OF TIE EXIRACTION COLUNS IN B PLANT WITH PUREX

Enclosed is a distribution of Waste Management Kaintenance manpower as it is now and how it would be in sequential operation. No appreciable reduction in maintenance manpower can be achieved by operating sequentially with this portion of the building. All building services and cell. monitoring equipment have to be maintained whether the cells are operating or not. Most of the equipment Involved is maintained remotely and would have little or no bearing on $B$ Plant maintenance forces.

It is much vetter, from a maintenance standpoint, to maintain a constant reduced force in each plant rather than rotating maintenance people from plant to plant for the intermittent operation and shutdown. The present method of exchanging manpower through the Maintenance Manpower Planning Meeting would be used to move people to do shutdown work as required. Assuming greater availability of manpower help from Purex, that portion of the maintenance forces assigned to B Plant can be reduced 10 percent as the result of sequential operation. i.e., from $3 y$ to $31=3$ pexple

AS : efg

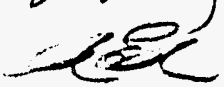

Encl.

cc: JM Blackburn

OV Smiset

RE Smith

File 
B PLANT SEQUENTIAL OPERATION WASTE MANAGEMENT MAINTENANCE

\begin{tabular}{clllll} 
B & EAST & REDOX & WEST & \multicolumn{2}{c}{ B PLANT SEQUENTIAL } \\
PLANT & FARMS & FARMS & 222-S & TOTAL & PLANT OTHER TOTAL \\
\hline
\end{tabular}

Manager

secretary

Planners

Engineers

For emen

Millwrights

Pipefitters

Welders

Electricians

Instrument

Coordinators

Painters

Asbestos Wkrs.

Instrument Maker

\section{1}

1

1

1

3

3

9

1

4

9

1

1

1

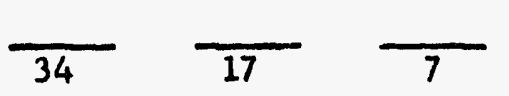

1

\section{1}

1

2

1

1

1

1

1

2

1

1

2

16

2

1

1

2

$\frac{1}{9}$

$\frac{1}{67}$

6

7

15

1

1

1

2

2

1

1

6

3

3

6

2

4

14 
Alianicic.

$\therefore \cdot \cdots: 460$

iny

Date: $\quad$ April 13, 1970

To:

O. F. Beaulleu

From:

J. M. Blackburn

Subject:

SEQUENTIAL OPERATION

Purex Malntenance manpower requirements for sequential operation are shown in the table below.

Present Craft Work Force

Sequential Operation

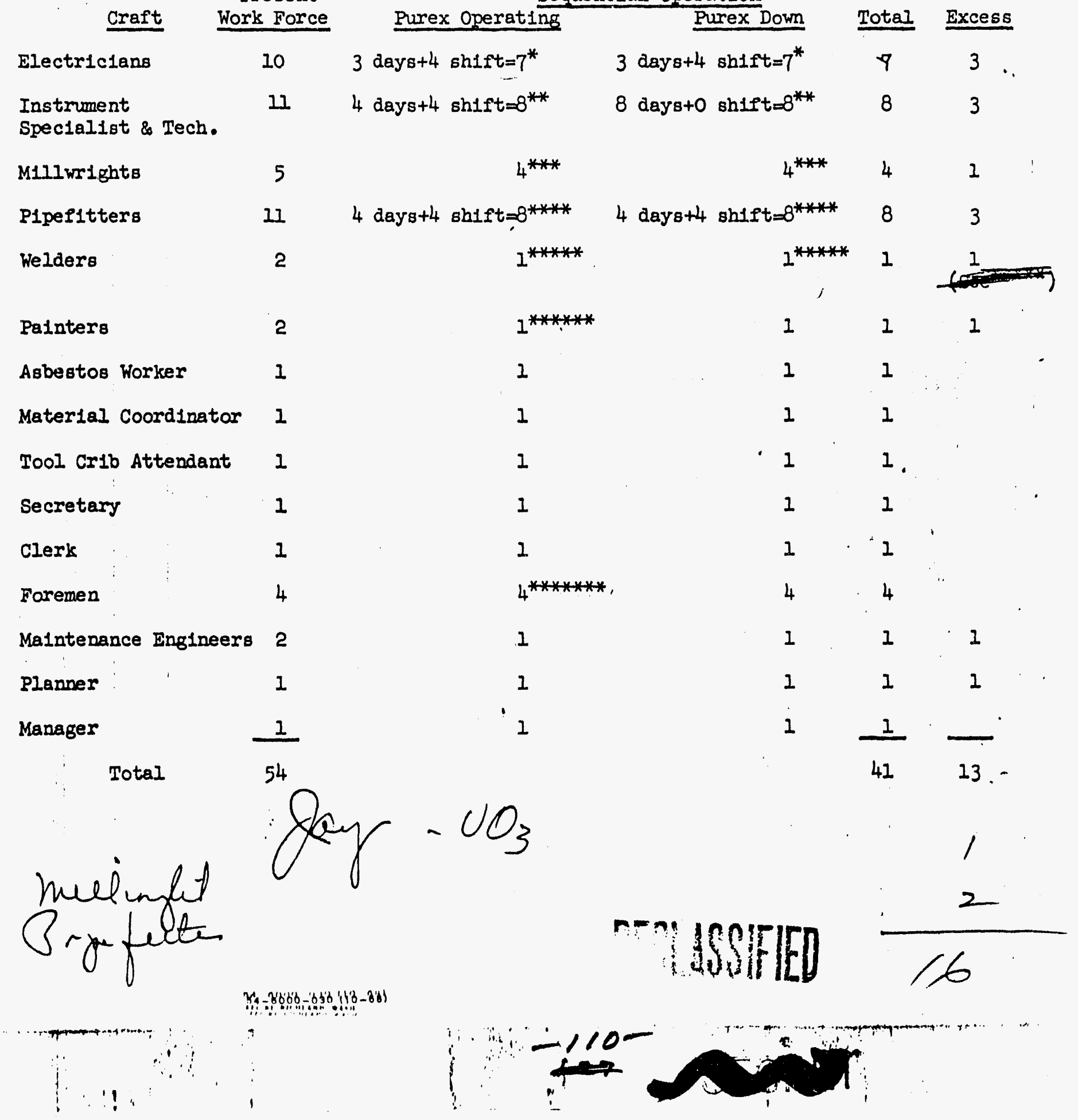


0. F. Beaulieu

Page 2

Apr11 13, 1970

* U03 will provide an electrician to Purex 50 percent of the time when the Purex Plant is operating and when it is down. Purex shift electricians w1Il continue to provide shift coverage to all plants in 200E and $200 \mathrm{~W}$ Areas.

** U03 w1ll provide an instrument tech. to Purex 50 percent of the time when the Purex Plant is operating. When the purex Plant is down, shift instrument tech. will be reassigned to day shift.

*** Purex w1ll provide millwright help to 403 as needed when the UO3 Plant is operating and when 1 t is down.

**** Purex will continue to provide shift pipefitter coverage for all B Plant operations when the Purex Plant is operating. When the Purex Plant is down and the U03 Plant is operating, Purex shift pipefitters will be stationed in the UO3 Plant during off hours; and they will provide shift coverage for all B Plant operations and Purex.

***** U03 w11l prov1de welder help to Purex and Waste Management.

****** U03 w1ll provlde a painter to Purex 50 percent of the time when the Purex Plant is operating and when it is down.

******* Presently, four foremen are required to supervise four separate crews. Under the sequential operation plan three foremen w1ll be required to supervise separate crews. The extra foreman will perform rellef work at Purex and UO3 Plants, supervise shop craftsmen that report to the Purex Plant, provide constant supervision to Purex craftsmen engaged in complex or hazardous work and perform special assignment work.

JMB: 888

cc: File

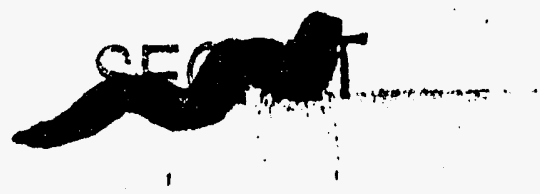




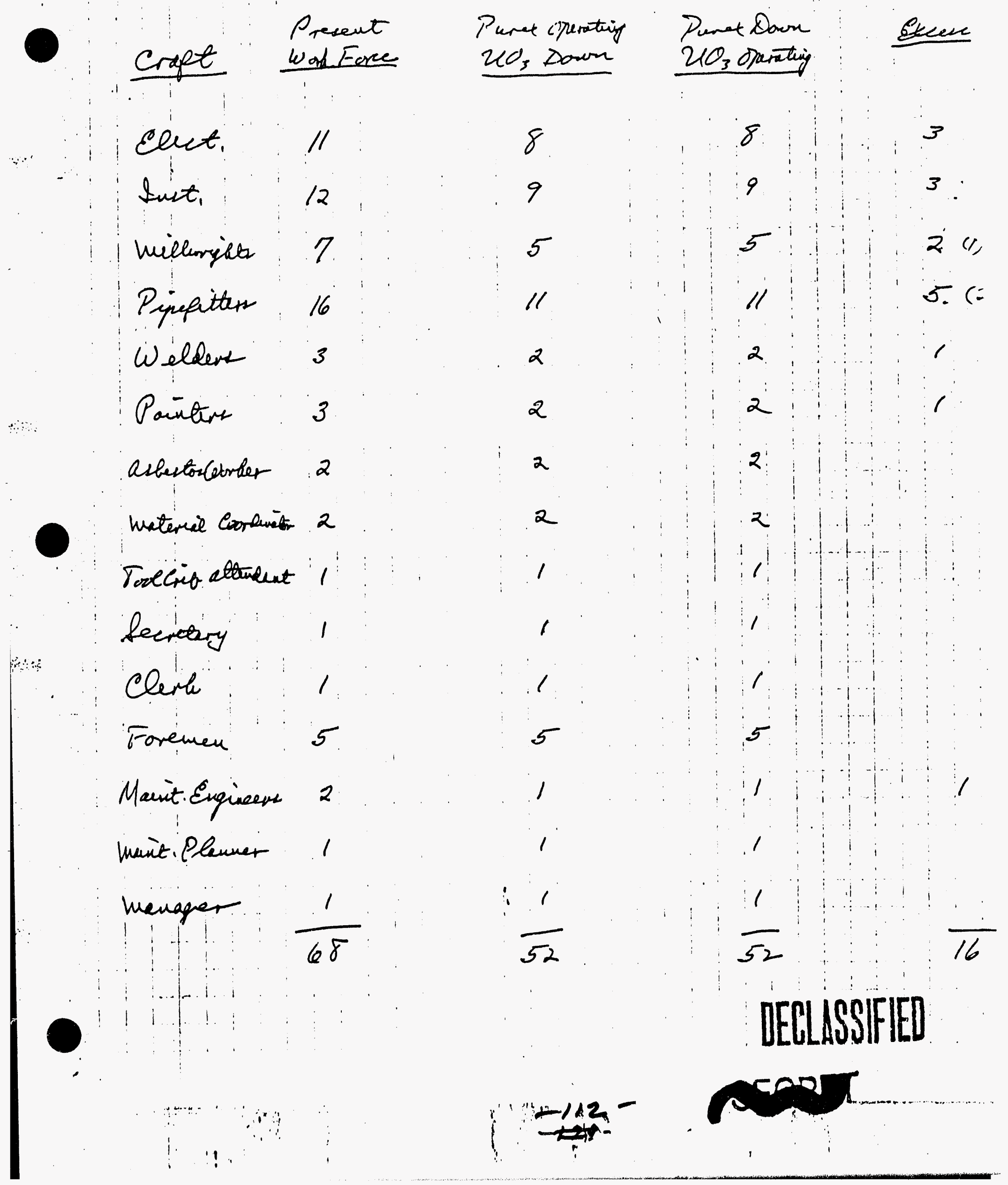


17000

\$ ot $\begin{gathered}1 \\ 0\end{gathered}$

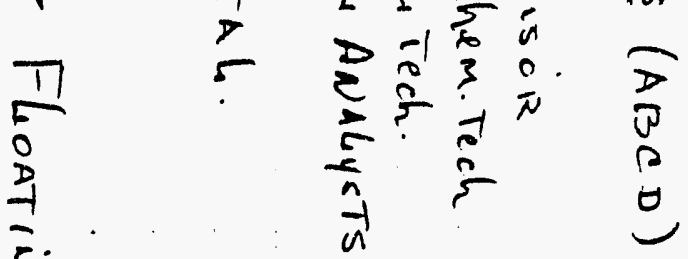

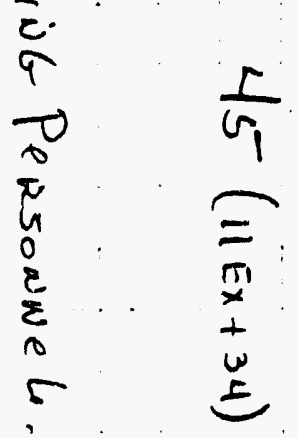

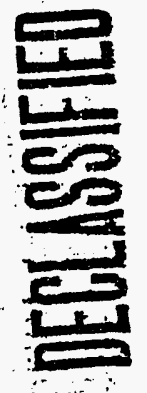

$\frac{5}{\omega} \| \bar{\sigma}=\frac{r}{\pi}$

$x_{x}^{x} \quad 0 \div$

uㅏ - - w - .

一昰妥罗?
ता

- $\frac{\pi}{x}$

$A^{-1} \sqrt{5}$

o.

L

O 1

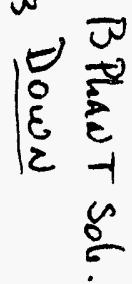

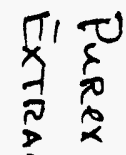

है

$+c$

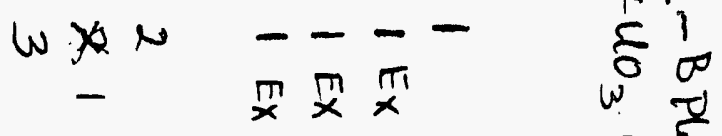

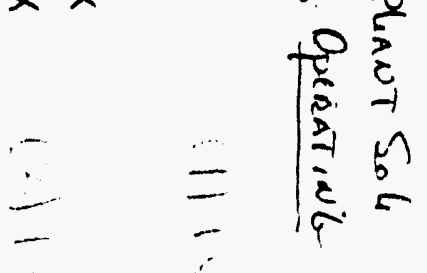

$l_{0}$

है

$\begin{array}{ll}5 \\ -1 & 0 \\ -1 & 0\end{array}$

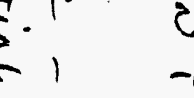

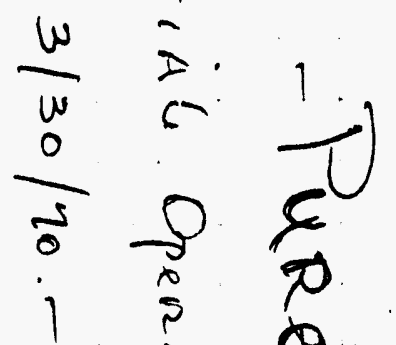

i

0.

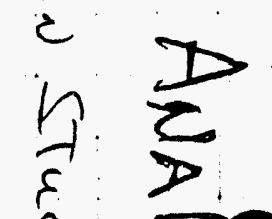

ह

$+5$

1 ㄱ.

ए

$\sum^{1}$

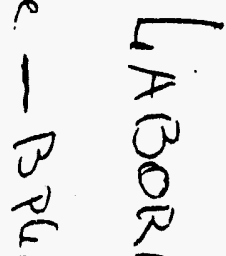

ह $\frac{7}{0}$

s $\pi$

2
2
-1
$\frac{1}{2}$
$\frac{\pi}{2}$
2

त)

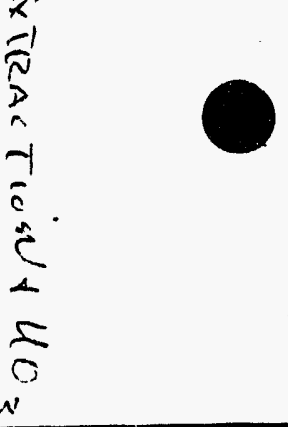




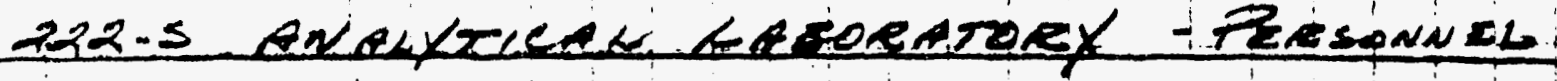

Estrmat.

Vonsterex

usfCRETAFY.

$\checkmark$ Pracess TECN LIPISON

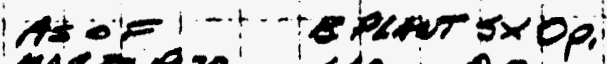

MAR $=19,20, \ldots 100 \mathrm{~s}$ Op.

expantsx

Eraresuras

ono no, onw.

STa.

Perertop

cirea

$\checkmark$ sepr - Day

VSUPY - STOS LAF

OSUPV - BUILDNES SERV - M

SUDV - TREANING

SUPV - SNIDT

CCHCOSST- EN HNOENMENT.

¿CHEAIST - LOUNTING ROOM

$4.4 \cdots$

is

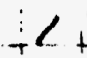

CNEMIST - STOS LAS

- CHEMIST- PAOC-Methos

CNEMIST - ANRLYTICAL

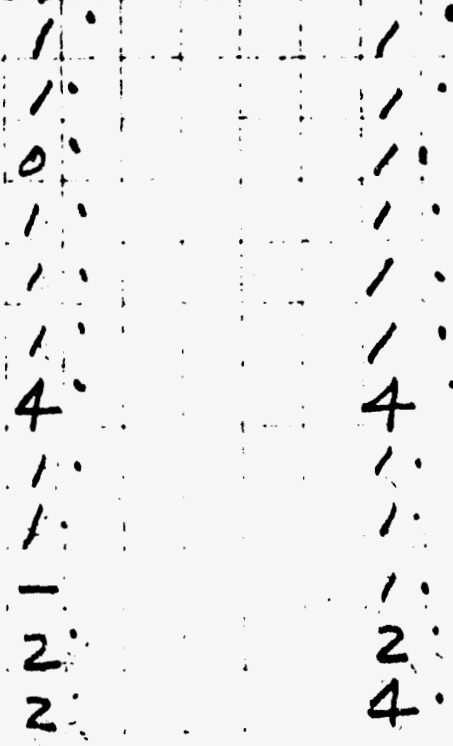

$-i$

conerts

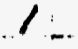

4

$\frac{1}{1}$

$\frac{1}{1}$

1

1

$2:$

2

2 .

SLCNEMITRLA. - SHIETLL. 4

- Daps

- ENVREN, -

$r$ "

- Eurapiseer.

1

4

$!$

1.

7

*. " -Cunt Em. 5

5

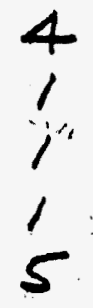

CHEM TLAN - SH/RT

4

$C A$

- $D A / S$

.4

4

- ENVHea -

$\checkmark 1$

- Burd. Servo.

2

- sTds LAB 4

4.

4

3

1

$\checkmark n$

16

2

2

2

4

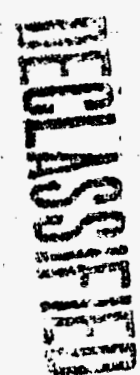

CHEM. ANALYST-SHIFT 24

$-4$

- DAYS

6

20

$-n$

- ENVIORN.

).

$\checkmark 1$

$-\mathrm{HO}_{3}$

$-11$

- C.R.

- traní,

TANITOR

TOTAL - NEN EX

TOTAL - EXEMPT

) 1

2

0

1

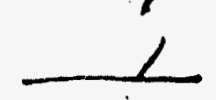

6

2

4

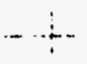




\section{जख्याप्ता}

Date: Apr11 16, 1970

To: $\quad$ T. Prudich

From: V. R. Chapman

Subject: BEQUEETTIAL OPERATION STUDY REACTOR BABIN INVENTORY

Attached is a table which shows the estlmated total basin Inventory of discharged uranium we would expect at varlous dates in the ruture if we, $A R B C O$, should start sequentlal operations in July 1971 and the N and KE reactor discharges follow the April 1970 1ssue of the Quarterly Production Forecast (ARR-1546)

We w1ll need from DUN the following information to include in our study.

1. A statement concerning capability to bulld the basin inventorles to these levels.

2. The added costs (annual) to store the quant1t1es shown.

3. Costs for reactivation of now 1dle basins should this be required for the loads shown.

VRC :mkl 

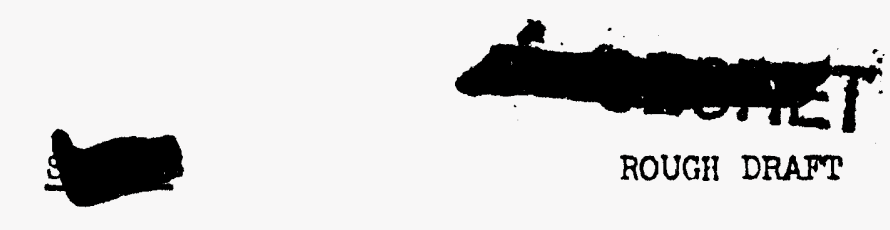

ROUGH DRAFT

SEQUENTIAL OPERATION STUDY

INVENTORY OF UITPROCESBED URANIUM BTORED IN REACTOR BASINS

\begin{tabular}{|c|c|c|c|}
\hline Date & Al-Clad 71 & Al-Clad 24 & 2R-Clad \\
\hline $6-30-71$ & 1347 & 710 & 362 \\
\hline $12-31-71$ & $2369 / 531$ & $-4024 / 12$ & 48048 \\
\hline $6-30-72$ & $2664 / 823$ & $78 \pm+664$ & Leq $46 \mathrm{t}$ \\
\hline $12-31-72$ & 18412017 & set 400 & 583602 \\
\hline $6-30-73$ & 22732357 & $775 * 652$ & -507596 \\
\hline $\begin{array}{c}12-31-73 \\
4-20 \cdot 74 \\
6-30-74 \\
8-31-74 \\
12-31-74\end{array}$ & $\begin{array}{r}-23012563 \\
2581 \\
27912915 \\
3103 \\
3255 \\
3140\end{array}$ & $\begin{array}{c}527400 \\
56 \% \\
795652 \\
232 \\
527 \quad 400\end{array}$ & 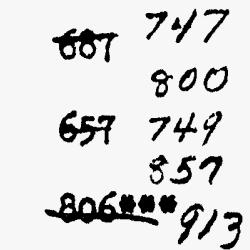 \\
\hline
\end{tabular}

Peaks at 3467 at end of February 1975 when there are 605 tons Al-clad 94 in besins.

ow Pecirs for Al-clad 94.

w* Peak for Zr-clad material for time perlod covered.
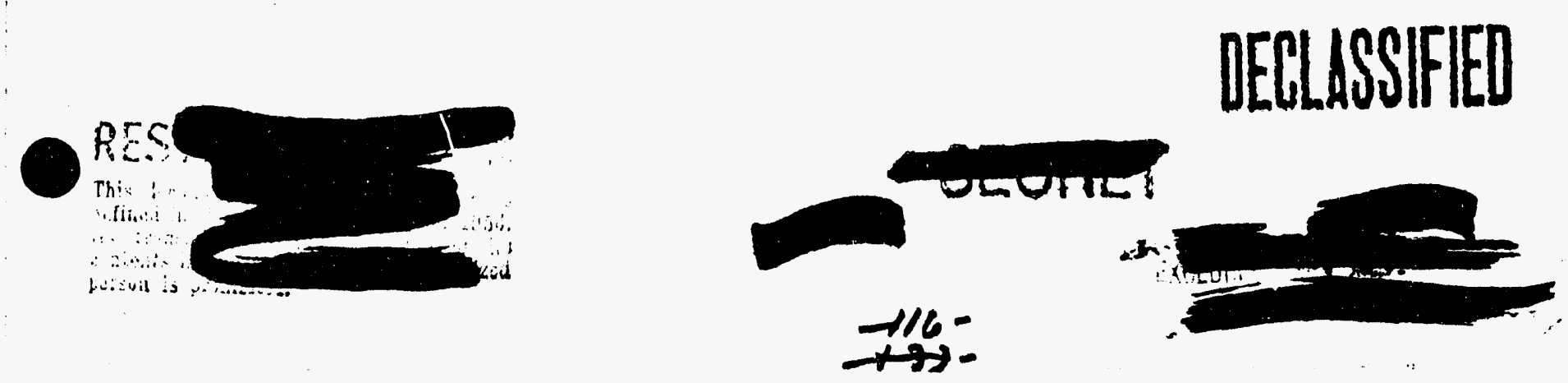
Dete: Apr11 23, 1970.

To: W. C. Calhoun

O. F. Beaulleu

J. D. McIntosh

R. E. Roberts

O. V. Smlset

Froia: $\quad v^{\cdot}$ ir. Chapman

Subject: SEQUEMTIAL OPERATION STUDY

FIKAL REPORT OUTLINE

Attached 1s a proposed outline for the flnal report of the sequential Operstion Study. Please revlow thls carefully and critically to determine what is belas orerlooked and whether you think thia will adequately cover our vork.

I have used the April Quarterly Production Forecast as a basis to rework the sequential mode tentative production chedule. It appears that we could operate sequentially unt1l about July 1975 before the basin inventories would force an reactor operation course.

Rather than drawling up a detalled operating model for each ilscal yeer, I propose one general purpose chart vblch mere 2 y ladlcates approximately what is processed when. Tho enounl throughput of each materiel (three types of Irradlated uranfum, tro types of Purex vante plun the Purax actd aludge) w11l be fhow in a tabie corrertag the four years broken dorn by quartere. In this way, anone who thinks be neede to 80 surther into detall, which cannot be predicted acourately, can get an 1dea of where sach type eampal con w1ll fell. The basin Inventory status vill bo shown in a table sinilar to the one used in our Interdm report.

T. Prudich has the beals inventory numbers and 18 now eccumulating estirate of the costs that will be 1nrolred. At this polat, he does not expect the to be prohibit1ve.

Ourrell and Kadoen w1ll here thelr manporer f1gures arallablo thls weok, as will MeCos and Mekurres. I an rasting to see what w1 1 derelop for Case I of the Reactor transfer tudy for the other ARHCO departmenta. These should flt our study.

I vould appredate those of you in operations aakfec if we have done all ve oan with the exempt payroll. I think Purax and B Piant should question wiso the contlaned use of trelve erane operators.

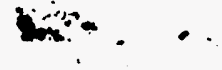

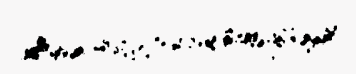

VRC : mk1

ec: MS Harwon

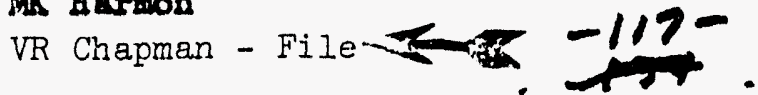

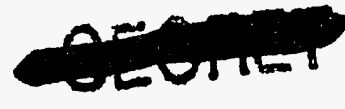




\section{- SEDimar \\ SEQUETTIAL OPERATYOH STUDY}

OUTLINE FOR FINAL REPORT

\section{INTRODUCPION}

D1scuss reason for 8 tudy and corposition of task force.

SUMMARY, CONCLUSIONS, AND RECOMMENDATIONS

1. Feasible but with certain rigks, particularly for N Reactor.

2. Does not Interfere with Waste Mangement goals.

3. ARHCO Manufacturing payroll can be reduced by $X$ number of people. List by Sections, exemt and nonexempt.

4. Annual operating costs reduced by X dollars below FY 1971 level.

5. Basin backlog would 1ncrease $X$ tons for aluminum-clad ruel and $Y$ tons of zirconfun-clad ruels between June 30,1971 through June 30,1975 under sequential plan. I dollars would be required some time 1n the ruture to process this excess.

6. Recomend adoption.

\section{DIscussion}

\section{General}

Explatn which portion of CPD operations are 1ncluded in the stuct and why certaln operations are excluded.

\section{Sequent1 al Operation Model}

Description - and production asurution used - assumption in an Appendix Production capaci ty of model.

Effeat on reactor besin inventories.

Parks.

Mempover Requi rements for Sequential Operations

Plant Operations

Operator Tradning

DECLLSSFFED

Plant Malntenance

CPD Serrices - Dlacuss Pover, Special Servlees and Bhop Servlces separately

Techn1cal Services - Analytical Labs, Radiation Monftoring

Fralities Engineorins 
Mannower Requil rements for Sequential Operat1ons - contd.

Operations Support Englneerings

Research and Engtineering

Other - Industrial Relations, Business Management

Comblned effect on ARHCO manpower

Budgetary Erfect of Sequential Operation

Shor comparlion of budgetary pattern for sequential rarsus nonmequential modex: to ylold estinate of annual saviags that would result.

Added Dun Costs

\section{Acknowledoments}

\section{References}

)

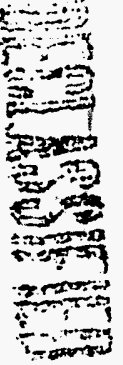




$$
\text { MLM }
$$

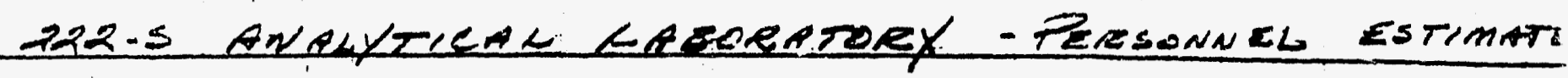

MANABCR SECRETARY.

PROCESS T TECN LIAISON

SupV - DAY

SUPV - STOS LAB

SUPV - BUILDING SERV - IBS

SUDV - TRAINING

SUPV - SHIAT

CHEMIST - COUNTING EOOM

CNEMIST - STOS $\angle 4 B$

CHEMIST-PROC-METHOOS

CNEMIST - PNALYTICAL
CHEMIST - EN VIDENMENT.

Asof "splat sxop, splaut Sx

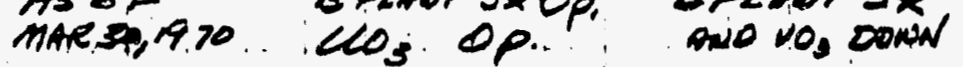

SLCAERMTRCHI - SHIETLL. 4 " " DAYS

- ENDIREN,

- Buingiscer.

- Covntrim

CHEM TECH -SHIDT 4

" "

- Envidian

- Buino serv.

- sids $\angle A B$

CHERI ANRLYST-SHIFT 24

" $"$ - SAYS, 6

- ENvilaral.

- $\mathrm{HO}_{3}$

$-C . E^{2}$

- trairi

JANITOR

TOTAL - AERIEX

TOTIL - EXEMPT
1

1

o

1

1

4

1

1

$\overline{2}$

2

ex Dowd.

Eizer.op

1

1

1

I

4

,

1

2
4

$\begin{array}{ll}4 & 4 \\ 1 & 1 \\ 1 & 1 \\ 5 & 5 \\ 4 & 4 \\ 4 & 3 \\ 2 & 2 \\ 2 & 2 \\ 4 & 4\end{array}$

20

8

2

2

2

1

1

58

$\frac{15}{72}=\frac{19}{32}$

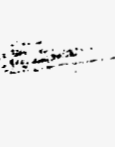

8
4

2

1

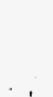

STa.

CREN

CONTR

I

4.

2

$T a-\Delta !$

12

4

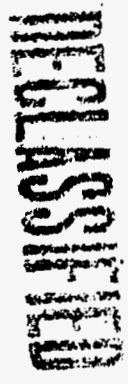

4

$-\frac{46}{-12} \frac{18}{58} \quad \frac{7}{25}$ 


\title{
Distribution
}

1. R. W. Calhoun

2. V. R. Chapman

Date: $\quad$ May 14, 1970

This documert conoss

To: R. W. Calhoun

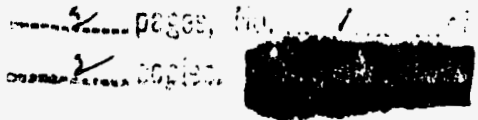

From: $\quad$ V. R. Chapman

Subject: SEQUENTIAI, OPERATION STUDY

Production statistics for the first three-and-one-half years under the sequential operations study plan are as follows:

\begin{tabular}{|c|c|c|c|c|c|c|c|}
\hline \multirow[b]{2}{*}{ FY } & \multicolumn{3}{|c|}{ Uranium - tons } & \multicolumn{2}{|c|}{$\mathrm{Pu}-\mathrm{kg}$} & \multicolumn{2}{|c|}{ CAW - gallons } \\
\hline & $\overline{K E ~} 71$ & $\mathrm{KE} 94$ & N $94-125$ & $\overline{\mathrm{WG}}$ & $\overline{F G}$ & $\overline{\text { PAW }}$ & $\overline{Z A W}$ \\
\hline & 1408 & 550 & 450 & 1200 & 250 & 129,230 & 117,0 \\
\hline & 1446 & 504 & 450 & 1330 & - & 128,700 & $1.17,0$ \\
\hline & 1446 & 504 & 465 & 1330 & - & 128,700 & 120,900 \\
\hline & 771 & 504 & 160 & 70 & - & 84,150 & \\
\hline
\end{tabular}

Uranium unprocessed over the period July 1, 1971 through December 31, 1974 due to sequential operation, i.e., deferred processing:

Tons

Aluminum-clad

. $2015^{\prime \prime}$

Zirconium-clad

540

Manufacturing manpower reductions resulting from sequencing:

After Sequencing

Present $\begin{array}{ll}\text { Purex } & \mathrm{UO}_{3} \& \mathrm{~B} \text { Plant } \\ \text { Oper. } & \text { SXOperating Reduction }\end{array}$

Purex-Beaulieu \& his org.
(I)

$\mathrm{UO}_{3}$-McIntosh \& his operators $(2)$

B Plant-SX-Smiset \& his people ${ }^{(3)}$

TOTAL

104

113

67

9

25

$\frac{109}{233}$

$\frac{81}{203}$

$\frac{111}{203}$

30

Purex Laboratory $(4)$
Redox Laboratory

\author{
4) 45
}

TOTAI

$\frac{72}{117}$

$\begin{array}{r}43 \\ 58 \\ \hline 101 \\ \hline\end{array}$

18

$\frac{83}{101}$
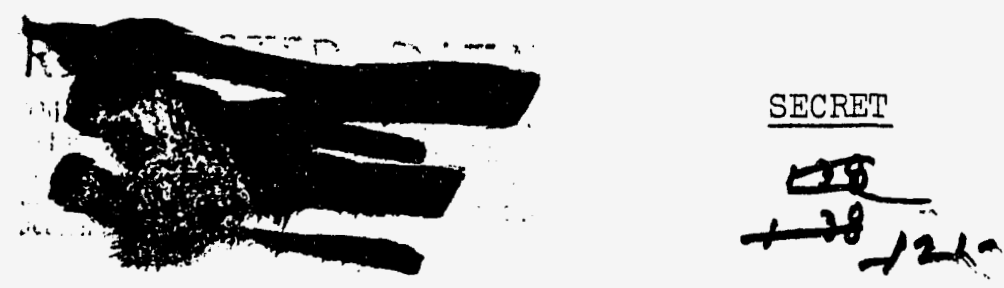


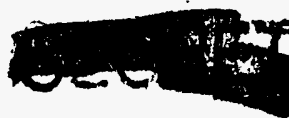

ROUGH DRAFT

Page 2

\section{Present After Sequencing Reduction}

Purex Plant-UO $\mathrm{UO}_{3}$ Mintenance $(5)$

Waste Management ."

TOTAL \begin{tabular}{rr}
54 & 41 \\
67 & 64 \\
\hline 121 & $\underline{105}$ \\
\hline
\end{tabular}

218
193
16

25

Plutonium Processing - No changes in operations, maintenance or laboratory.

Total manpower reduction

(1) Malody and remainder of his staff not included.

(2) McIntosh and his operating crew. Maintenance calculations separate.

(3) Excludes R.E. Smith, his staff and Roddy and his people.

(4) Gurwell and Madeen and those reporting to them. After sequencing one manager over the two laboratories. P.W. Smith and others excluded.

(5) Blackburn and his people, including $\mathrm{UO}_{3}$ Plant maintenance.

(6) Alex Smith and his people.

(7) McCoy and all his people. Power organization unaffected by sequencing - all reductions made in other two subsections.

From all that goes before, I need an impressive table which shows (I) the reductions in annual budget resulting from sequencing, and (2) the costs deferred as a result of the basin inventory buildup, i.e., 2015 tons of aluminum-clad and 540 tons Zirconium-clad.

The floating portion of the operating crews will spend time approximately as follows :

$\begin{array}{llll}\text { Purex } & 180 \text { days; } & \text { B Plant } & 185 \text { days } \\ \text { Purex } & 275 \text { days; } & \mathrm{UO}_{3} \text { Plant } & 90 \text { days }\end{array}$

My guess is that the laboratory floating group will follow approximately the Purex-B Plant distribution.
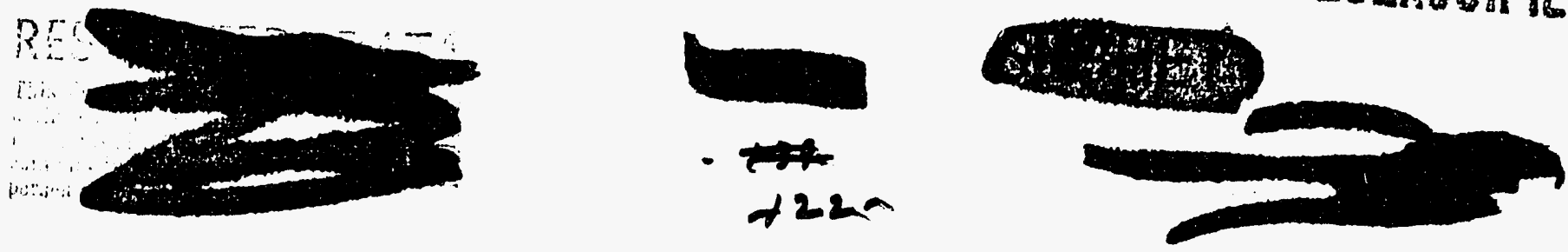


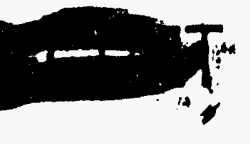

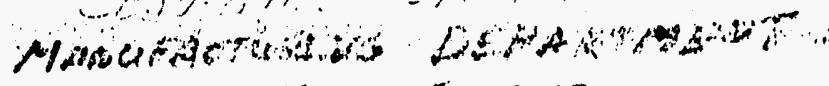

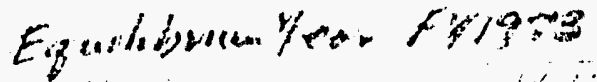

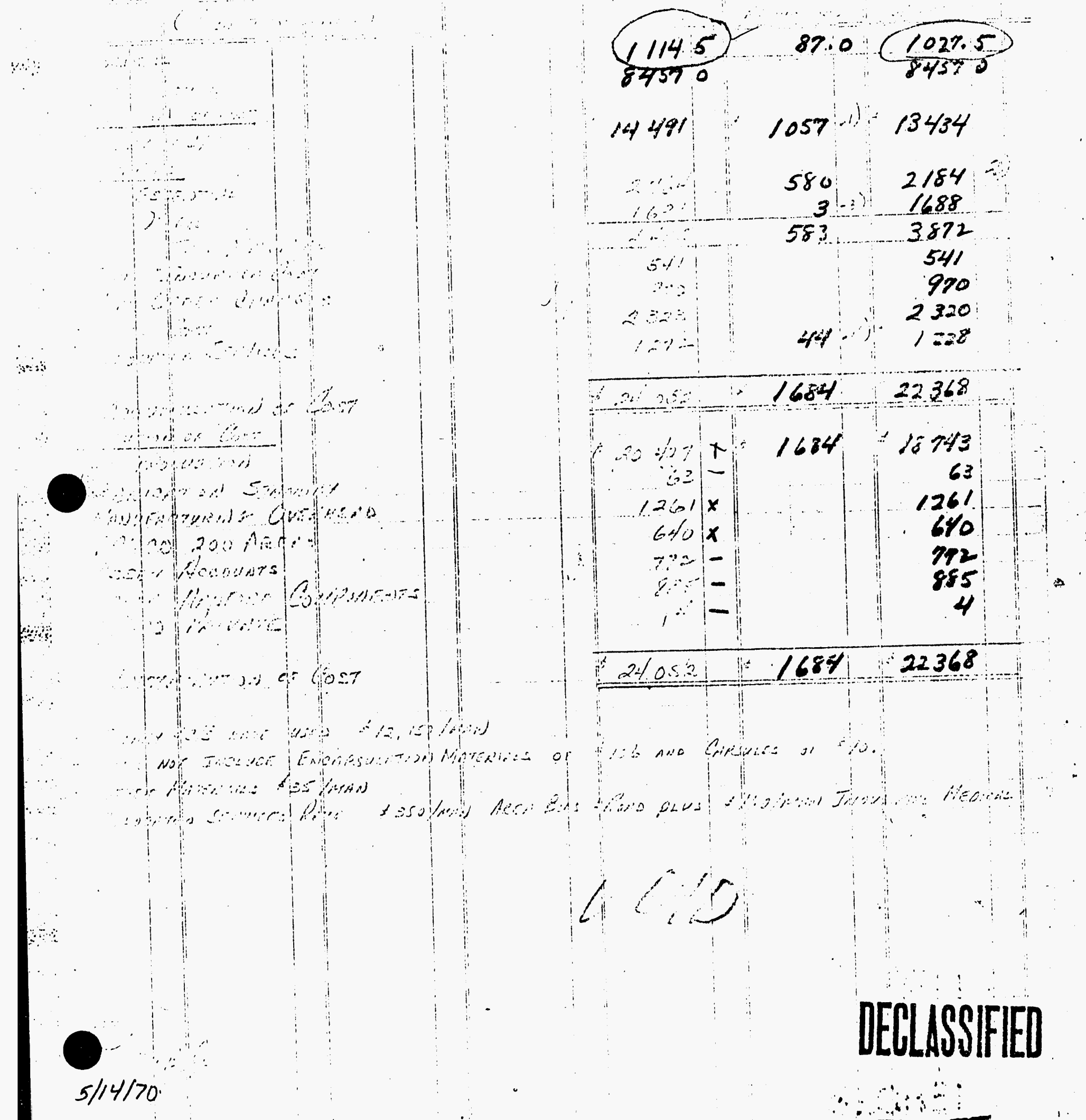


85

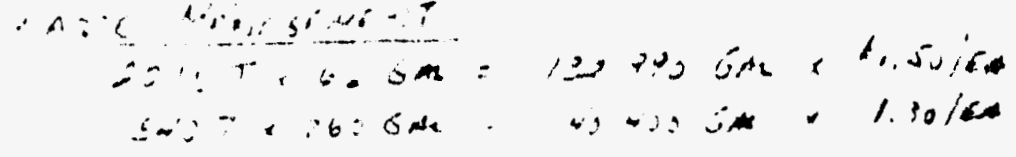

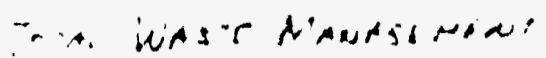

$\therefore$

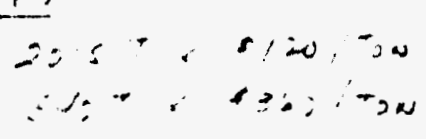

$\because \div$

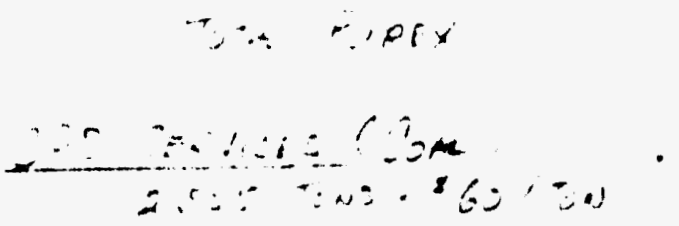

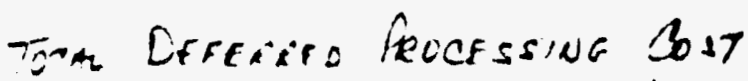
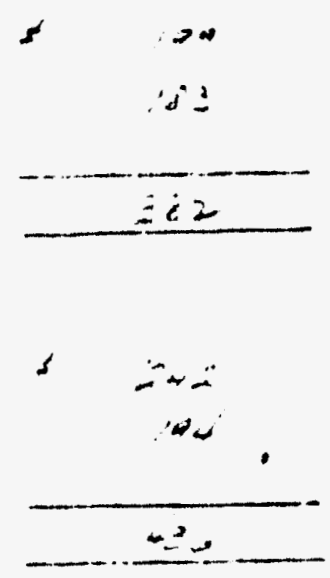

$1 \quad 53$

$+771$

1

$\therefore$

DEELLSSSFIED

$-121$ 


\section{SS779בด}

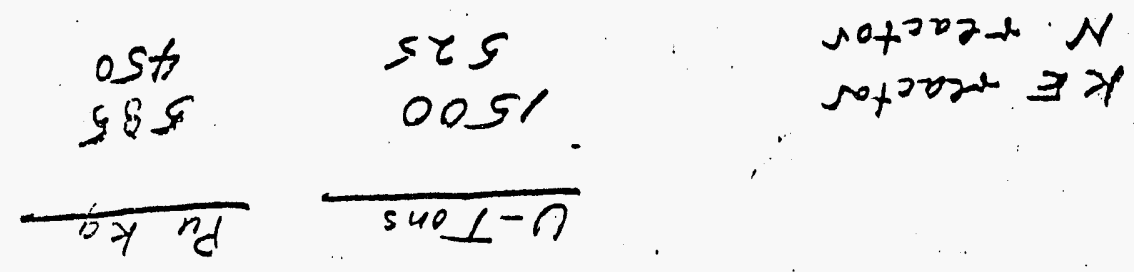

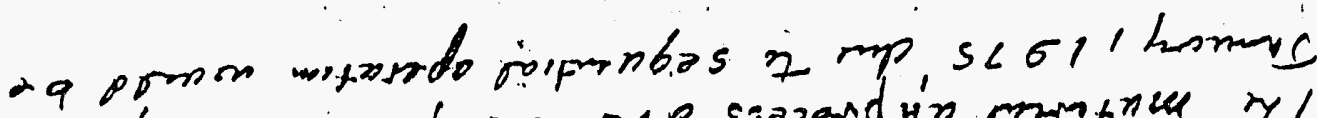

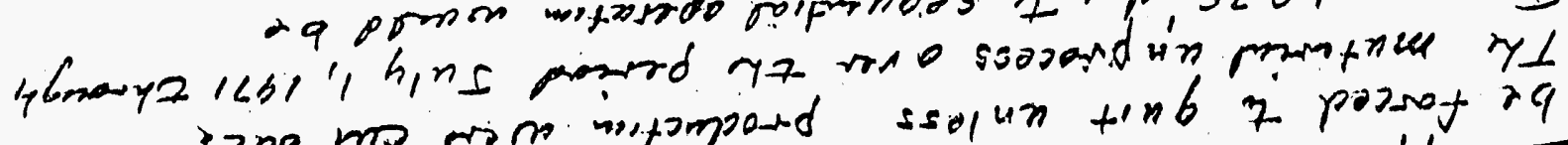

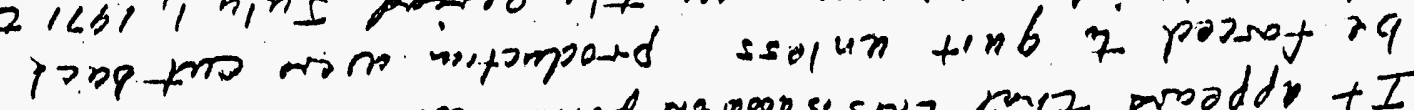

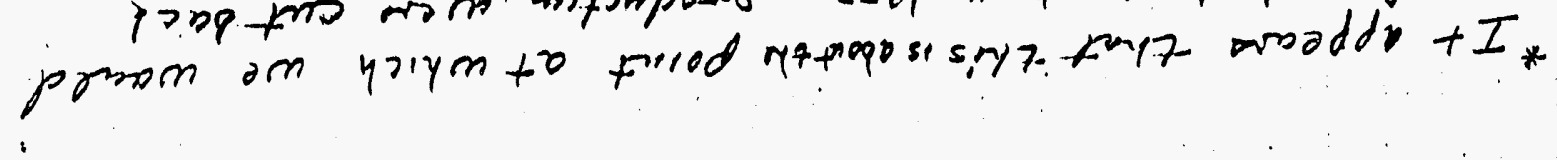

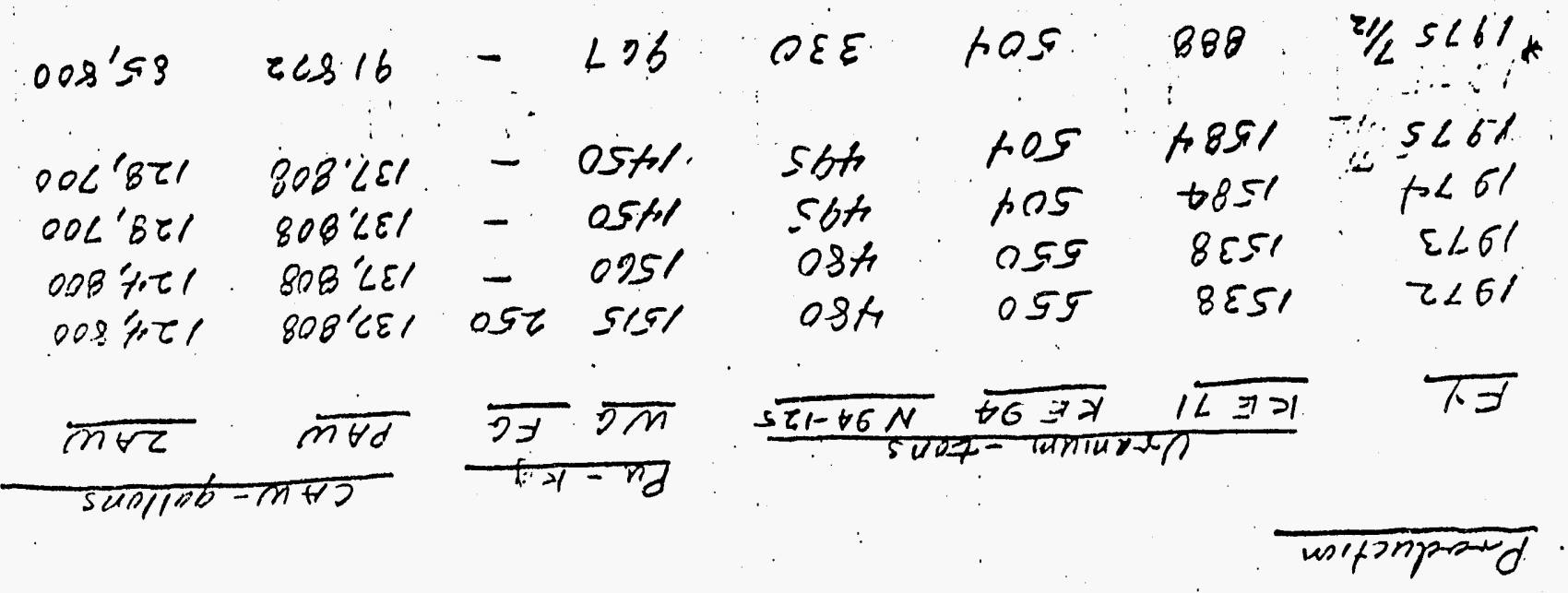

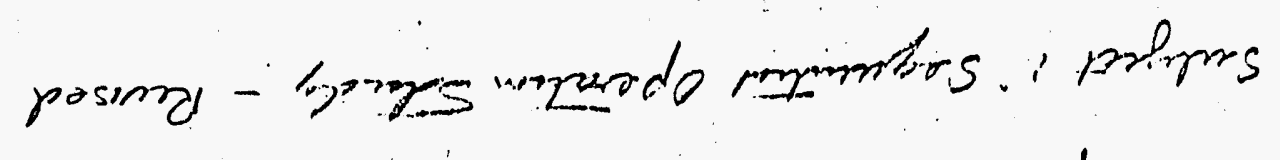
wenterany 01 unoulos $\mathrm{my}$ oLGI'OI BNIS 


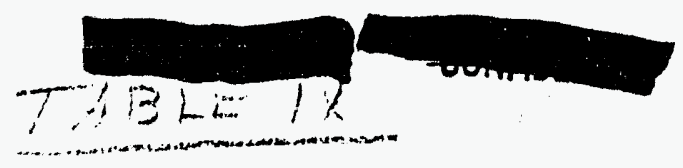

Ha: :i- :

in 200 is ;

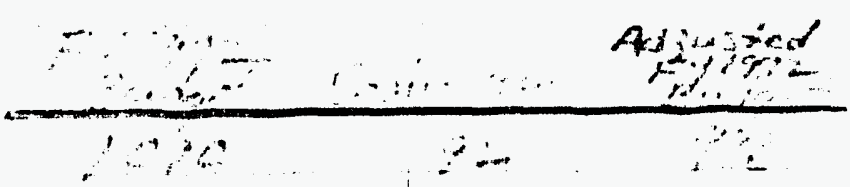

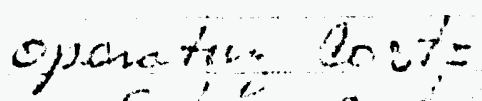

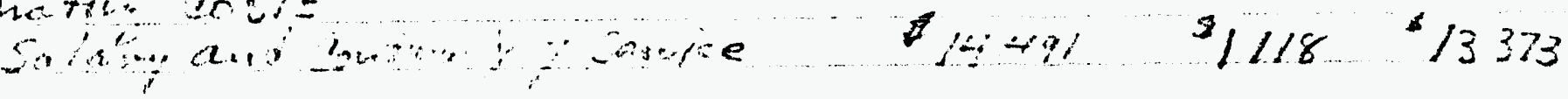

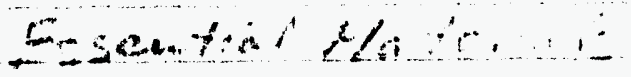

\#20

$303 \quad 2461$

thar thaters

$\therefore \because$

$21 \ldots 3$

par Inector in

541

$209+2 x+80+000$

$\therefore \operatorname{lag}$

232

77. $43 \%$

$\frac{1}{1} \sin +2$

$212=240$

$20 x-20 x+2 y$

$24052 \quad / 551 \quad 22501$

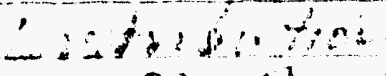

$62+2 e+1+\cdots+4$

$82328 \quad 15=1017$

$\therefore \%=$

- $192 \%$

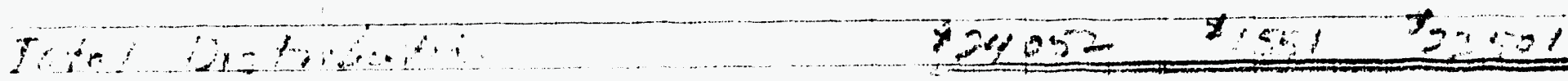

CSE

DECLLSSSIFIED

$=1265$ 
$5-22-70$ to $6-19$

li

From T Predich by Phone $1 \frac{30}{p}$

$K E, K U) \subset \mp B$ Busins present in apoindm

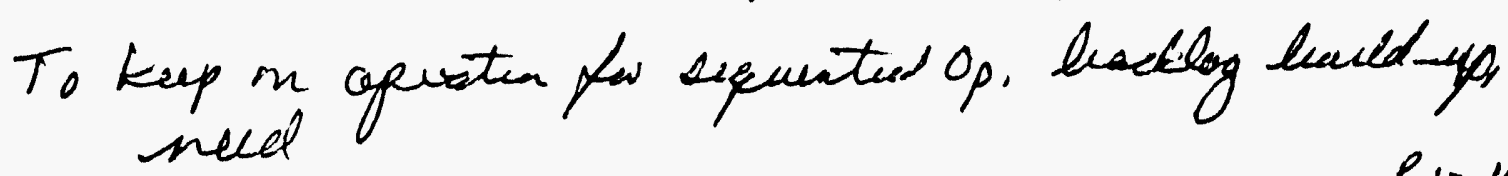

4 prople at $\$ 13,000$

$\frac{\rho \text { es year }}{52,000}$

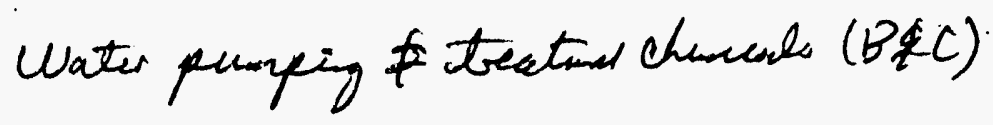

Toted

$\frac{20,000}{67,000}$

Budes

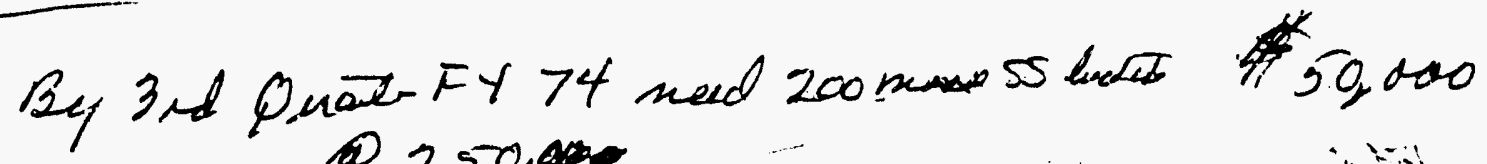
C250,000

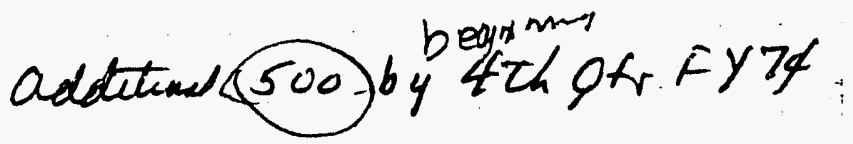

25,000

100,

Giluanged luekts are and entenes to delemete.

Coed avod luaket by stuch natural lik cordurod. Two nave pesfece divered he mendel to hadle

$122=$ 


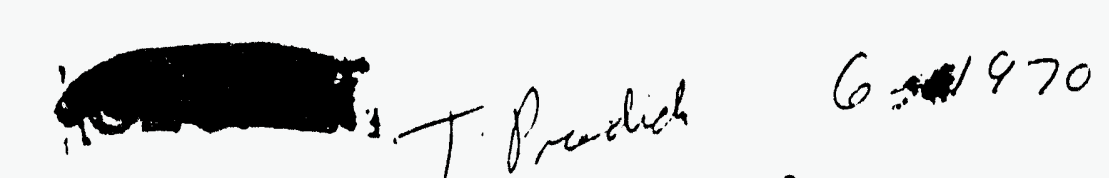

300 mantinien buedets neuled

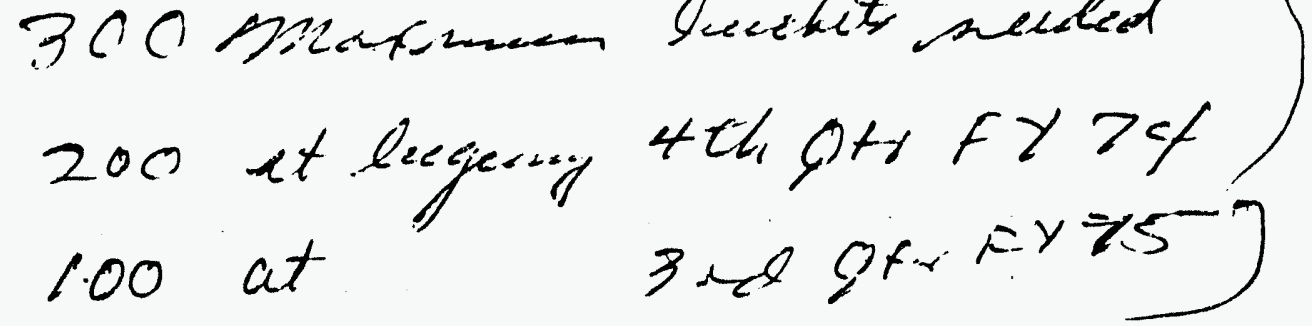

ind of $=y+5$

$2 ?: 1$

OEELASSFFED

$=128-$ 
$\therefore$ For Harot

$$
\begin{aligned}
& \text {, Ti, comply }
\end{aligned}
$$

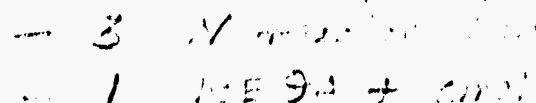

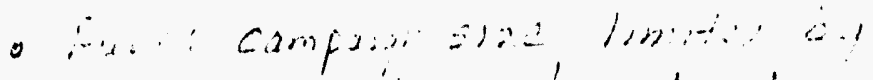

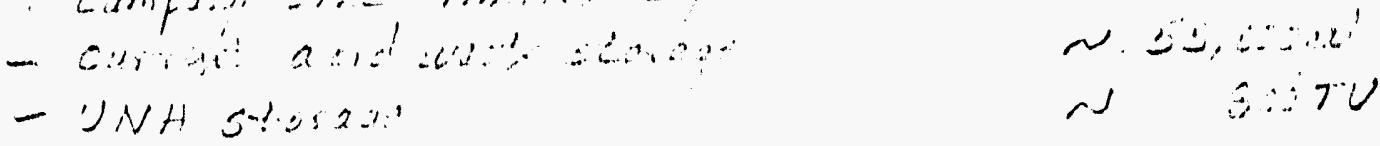

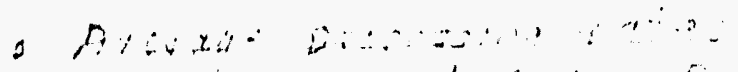

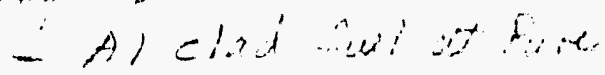

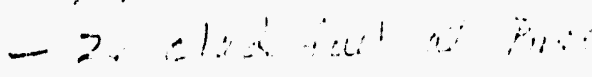

$$
\begin{aligned}
& \text { - PAS } 103 \text { Fin. } \\
& \therefore \text { and }
\end{aligned}
$$

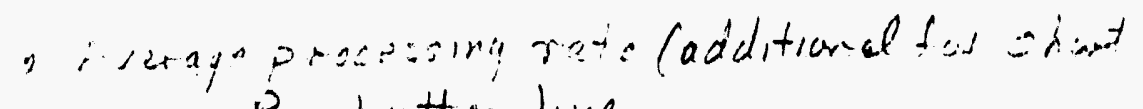

- Pu buttor line.

- $\mathrm{OO}_{3}$ flime

17. Eq/ing 40 Tulday

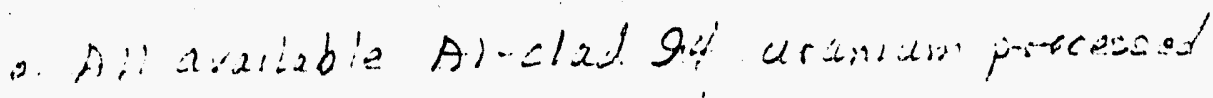

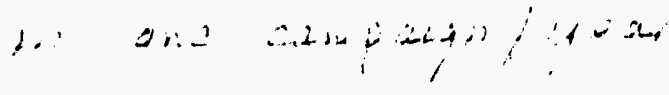

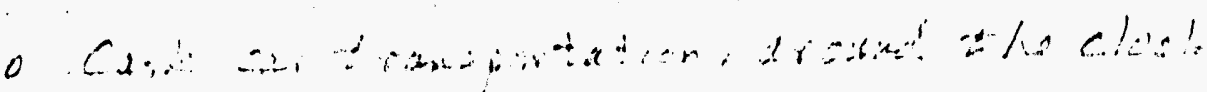

$7 d x=f(20) ?$

DELLASIFIET

$3-9.70$ 
$O 2+2-2$

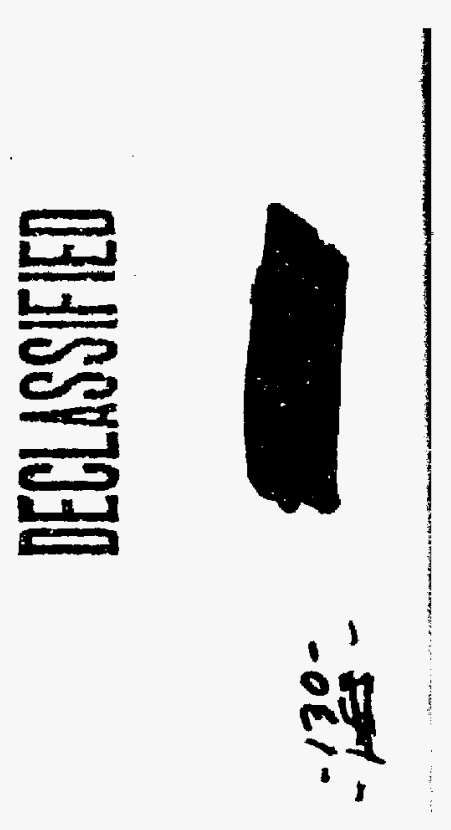

I
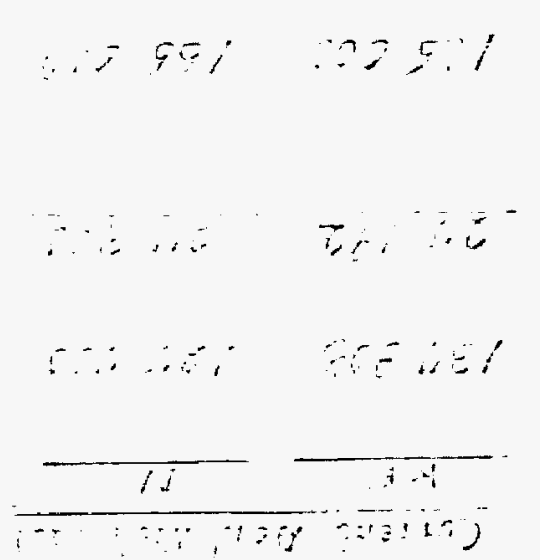

$\therefore \quad-66$

60

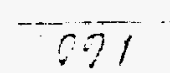

501

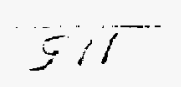

20

QE:

028

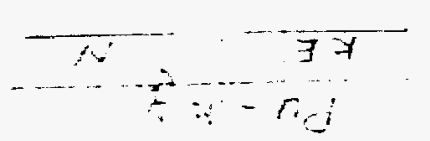

$\operatorname{set}$

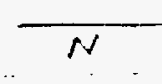

$3>1$

0055

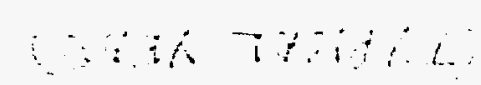

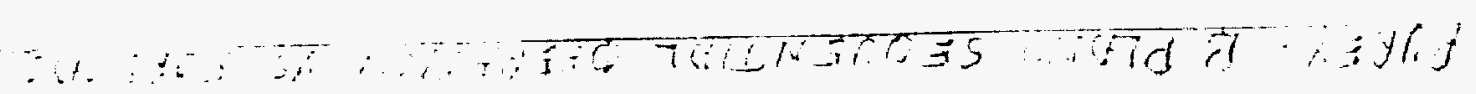




$$
\begin{aligned}
& \text { iniw Sequntial Standy } \\
& \text { Fis } 00 \% \frac{69 \%}{650}=100 \% \\
& 150 \times 107=160] \\
& 5 \text { suce tep fuits ptor } \\
& \text { pies stiux: } \\
& \text { IECLLSSSIFIED }
\end{aligned}
$$

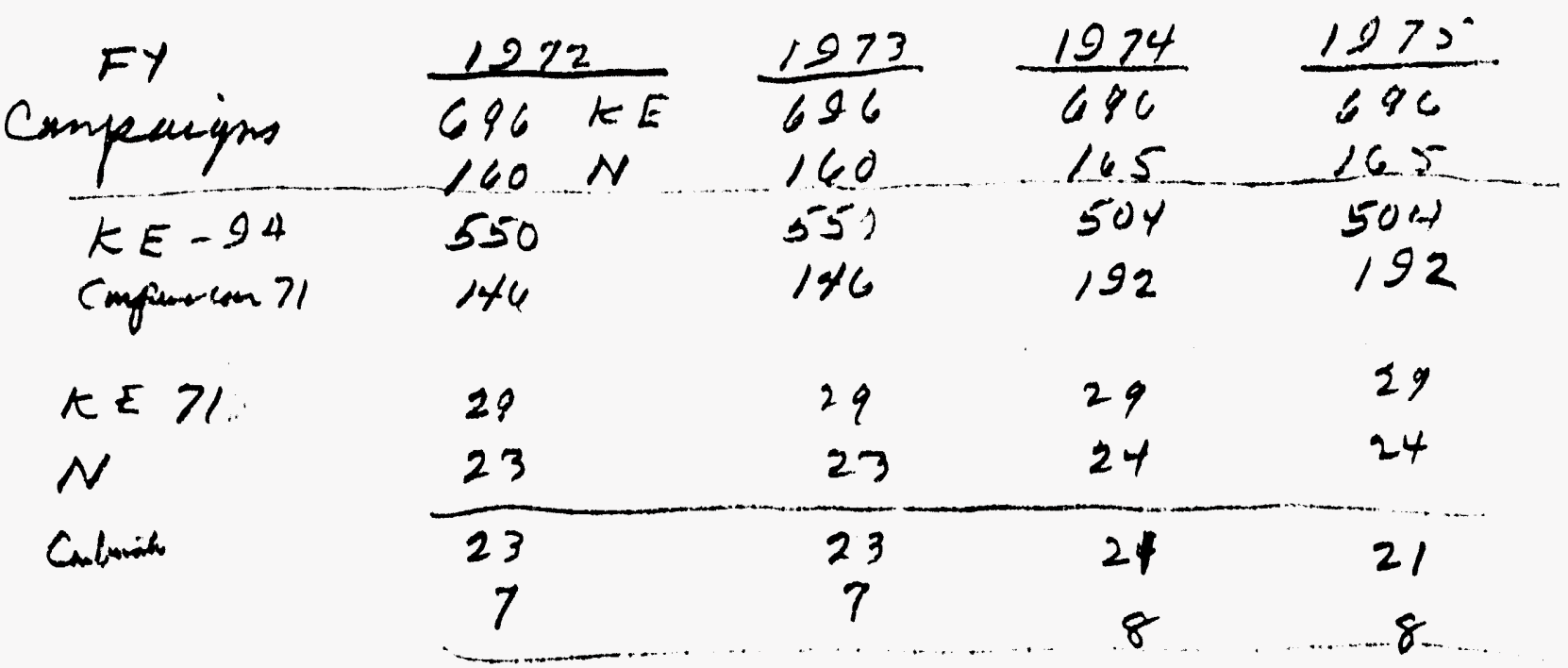

$$
\begin{aligned}
& 2088
\end{aligned}
$$

480

$K^{250 k g}$ facha

1972

$$
\begin{aligned}
& 550-308012 \%=242 \mathrm{tm} \\
& 242+1538=17801780 x .5=873 \times 9 \\
& 480 \times 1.3=824 \\
& 024+290=15 \mathrm{Hk} \text { wapher }
\end{aligned}
$$$$
1973 \quad 2088 \times 425=939
$$$$
480 \times 1.3=4=0
$$$$
6211+1037=1563
$$

1374

$$
\begin{aligned}
& \therefore 8: 00.4=895 \\
& 495 \times \frac{=143}{1478}
\end{aligned}
$$$$
1975 \quad 3 / 2 \begin{aligned}
& 888+504=13127 \\
& 1392 \times 4
\end{aligned}
$$$$
330 \times 1.3=\frac{429}{986} N
$$

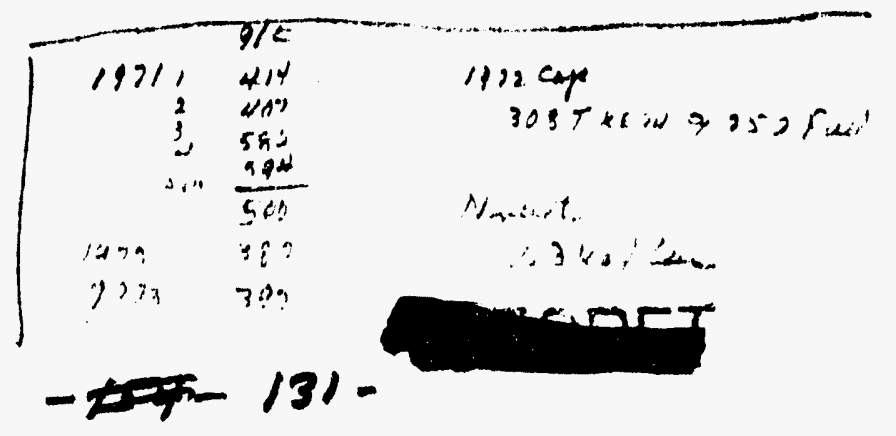




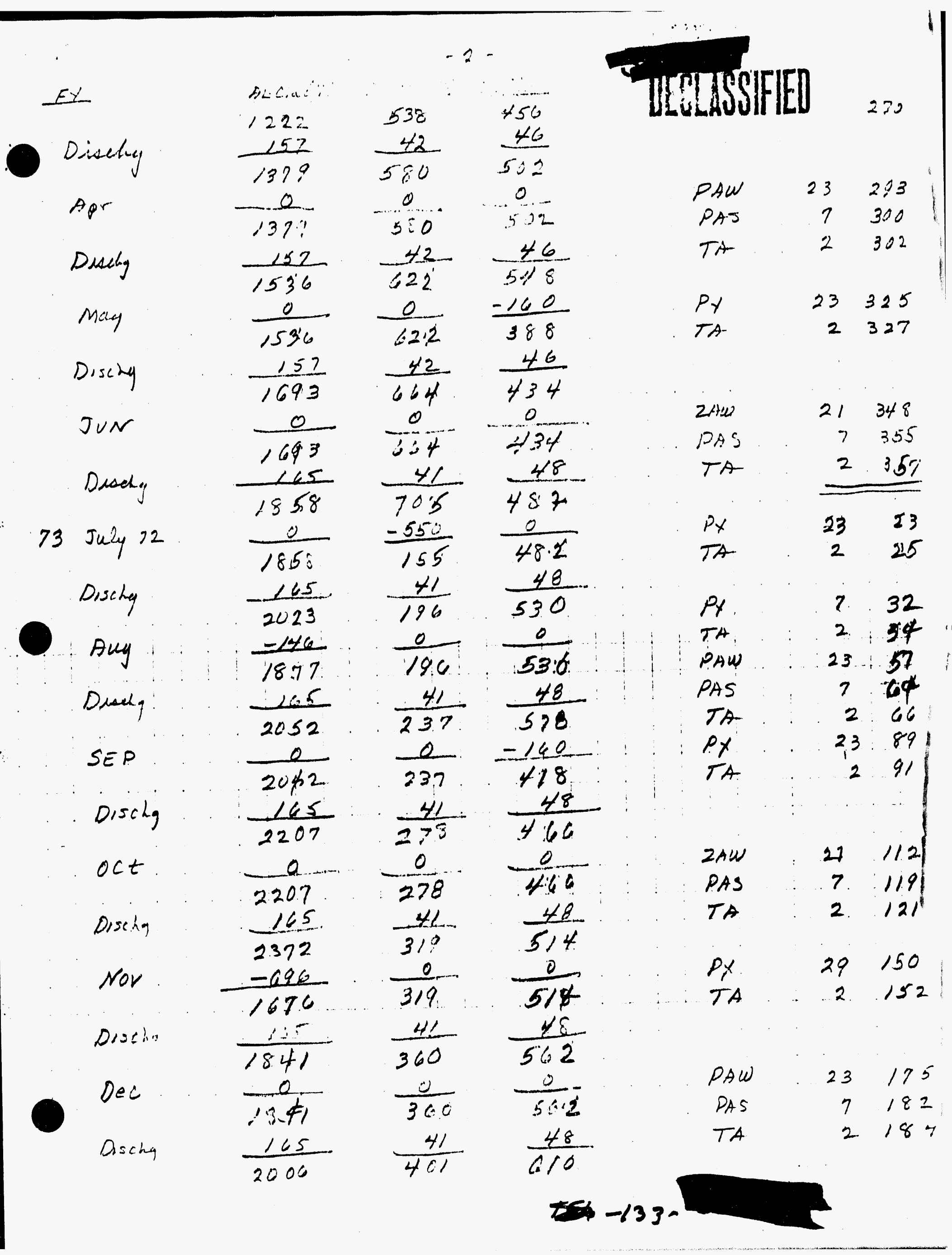




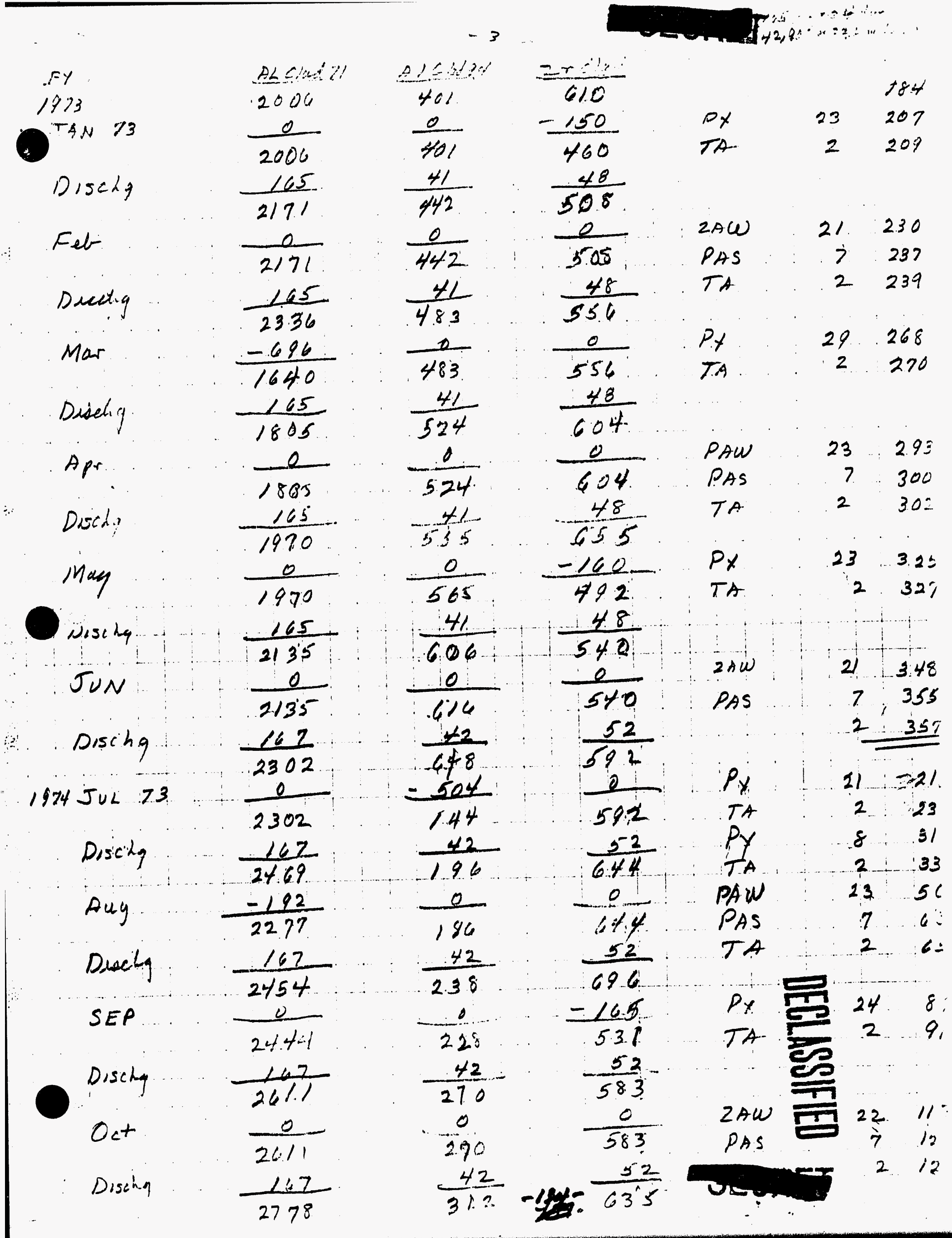




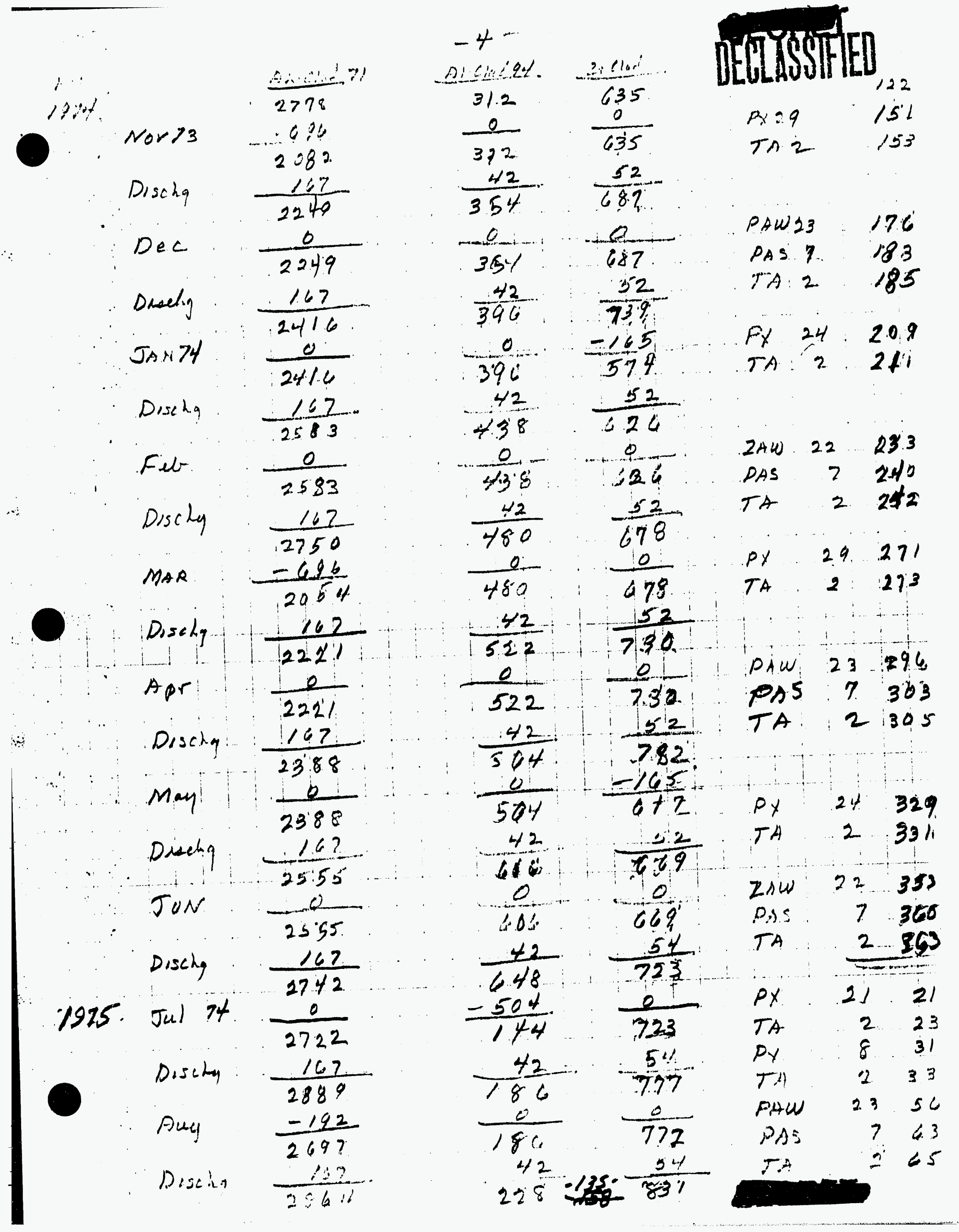


.5

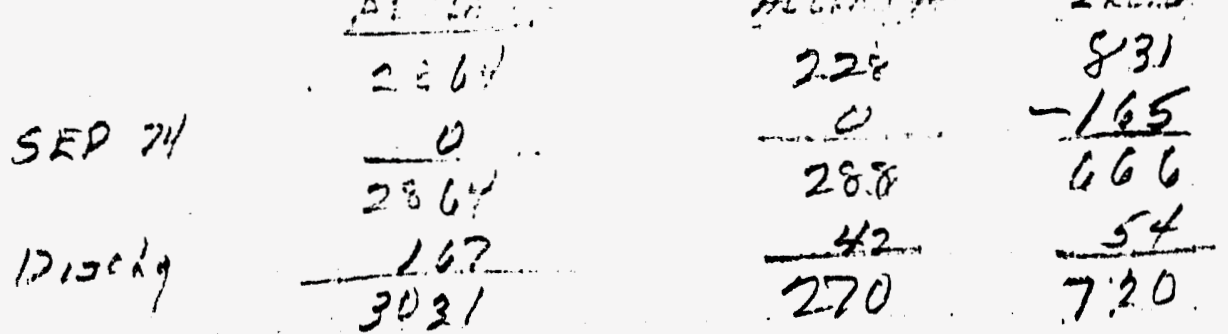

Oct $\frac{0}{303 !} \quad \frac{0}{200} \frac{0}{720}$

\begin{tabular}{ll} 
Disel & $\frac{167}{3198}$ \\
Nov $\frac{-696}{2502}$ & $\frac{42}{312} \cdot \frac{54}{774}$ \\
\hline 372 & $\frac{0}{774}$
\end{tabular}

Disct, $\frac{167}{2669} \quad \frac{42}{354}: \frac{54}{828}$

Dee $\frac{0}{26.54} \quad \frac{0}{354} \cdot \frac{0}{828}$

Dischg $\frac{167}{2836} \quad \frac{42}{396} \cdot \frac{54}{862}$

$\tan 25 \frac{0}{2836} \quad \frac{0}{396} \frac{-165}{377}$

fed $\frac{147}{30103}$

Prosely $\frac{167}{3170}$

$\frac{\frac{42}{48}}{0} \frac{\frac{54}{177}}{13}$

$\frac{42}{480} \quad \frac{54}{825}$

Mar $\frac{-996}{2474}$

$\frac{0}{480} \quad \frac{0}{825}$

Disehy $\frac{167}{26.41} \quad \frac{42}{522} \frac{54}{879}$

Apr $\frac{0}{241} \quad \frac{0}{522} \frac{0}{879}$

Pject $\frac{167}{2608} \quad \frac{42}{564} \frac{54}{933}$

May $\frac{0}{2809} \quad \frac{0}{501} \frac{-165}{768}$

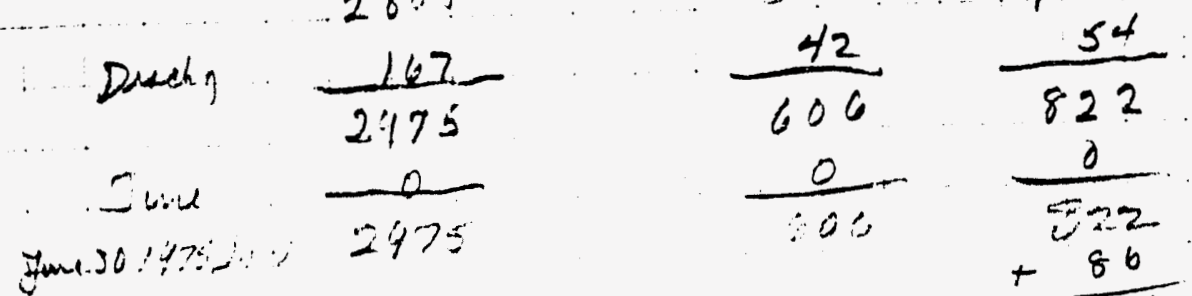

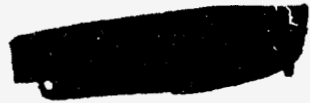

Pि 24

36

TA 2

89

ZAW $22 \quad 11.3$

PAS 7120

TA: 2. 122

P. $29 \ldots 151$

TA, 2 153

PAW 23.1.7.6

PA7 :7.183

TH 2185

$=136-\frac{+86}{908-U \text { usen }}$ 


\begin{tabular}{|c|c|c|c|c|c|}
\hline \multirow[b]{2}{*}{$F y$} & \multicolumn{3}{|c|}{ Urabuen - TaN } & \multicolumn{2}{|c|}{ Plutorias $-\mathrm{kq}$} \\
\hline & KE TI & KEI 4. & N94-125: & weapin Grale & Fuel, Grade \\
\hline 1972 & 1538 & 550 & 480 & 1515 & 250 \\
\hline 1973 & 1538 & 550 & 480 & 1563 & - \\
\hline 1974 & 1584 & 504 & 495 & 1475 & - \\
\hline 1975 & 888 & 504 & 330 & 985 & - \\
\hline
\end{tabular}

$\frac{1}{10}$

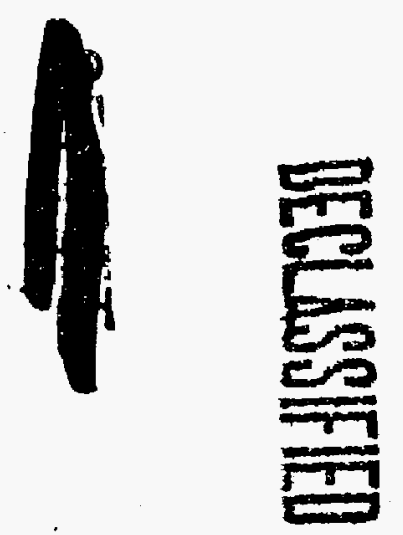


1. TRANNING OF MANPOWER

Assuming decisions to go to sequectial operation in FV 196918 mads Novenched 1, 1967

- We have a maximum of 8 months in which to retrain i) $x$-number of Wast Marageaned employers in Purer $\neq \mathrm{NO}_{3}$

- We have a marimem of 4 months in which to train $X$-nmabes of Purex $\Varangle \mathrm{UO}_{3}$ empleqees in Waste Managenat, During thas persod, every body runiring B-Pleut are in effect training because it's a new operatime

Quertion: When can we opring Pures ad U6, peoplo loore for this trasinsy

2. Waste Manayement Objectives

Sequential operation slows down phasos of the waste Mavargensed progran

Ouestions Does this not ran cauntas with the objectivity to imsonilize radisactive material as quackly as posoble? Is this not cauntar to national posture on pollutim control?

3. Risles are increased

a. UOS plant relatively low in sigrificasce became of absence of critical mass control problems and low order radiatim problums.

Erosors would cause produrtion loss and possible lose of high preced materid.

b. Waste Managemat extramely high. Error could easily rescelt in spread of radioactive materials setting up radiater fielde almact impossible to cape with. No critical meass cutrol problems

C. Purex Plast high. Exrors in Pu tail-end equipment could wesalt in crstical mass Ircedent. Sosar potrastical for spreading extremely hegh radioactive contaninetion 
4. Increased First hive Supervision

It = quite probable that the ratio of first line superversm to craftsmen weceled be increased in an effort to compensate for decreased total knoulodgetecontat and skill of work farce. This cesturnily is the prudent action. Additionally, Waste Manaygunet and Purer nicest be supervised during is th idle periods. Since Waste Management will be idle twice the tires Purer will be, waste of talent will take place in on area wo slowed bo pressing furcuard in rather then curtailing

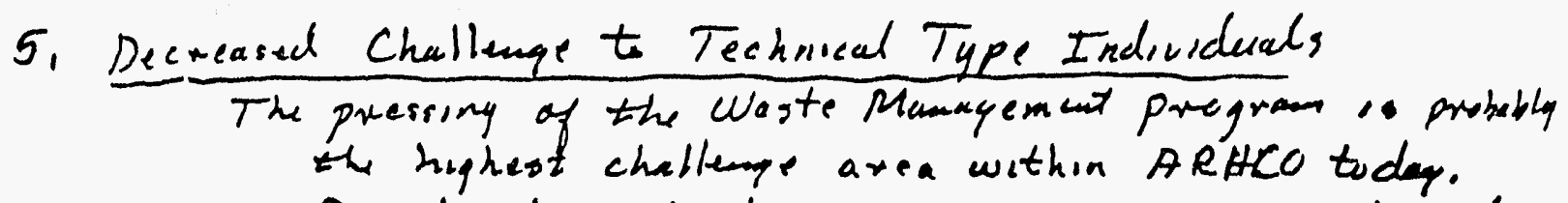
Deceleration of this pregromen, removes much of the challenge. This curtailment along with the curtulimente that result from 5 ar $10 \%$ cut beck would probably increase the exodus of younger engineers.

$-7$

DELLLASSFFED

$-138-$ 
P?..:1

July 20,1970

To: M, K. Harmon

FRom: V.R. Chapman
Copy 1. MK Harmon

2. VR Chapman
This document consists of

_..... pages, No....L.......... of

Alternatives for Reduction of ARHCO COSts

Ores we are past the thorium- ${ }^{233} \mathrm{U}$ processing campaign and have reduced the reactor basin uranium inventories to a normal level, the time requirement for Puree to process reactor output will be about as follows:

4.0 CF $972 \%$ Efficiency

2000.T IE $71 \div 24 T / D$

$500 T$ KEY $T$ T 24T/D

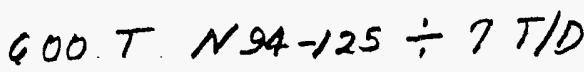

Turnaround

Idle
Days Total

84

21

86

38

131

360

3.6 CF@ $72 \%$ Efficiency

$$
\begin{aligned}
& 2000 T \text { lEVI } \div 21.6 T / D \\
& 500 T \text {. iE } 94 \div 21.6 \mathrm{~T} / \mathrm{D}
\end{aligned}
$$

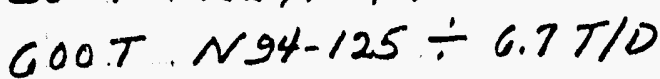

Turnaround.

Idle
.93

24

90

38

115

360

4.0 CE@ 60\% Efficiency

$2000 T$ TE TI $\div 20 T / D$

$500 \mathrm{~T}$ KEP $\div 20 \mathrm{~T} / \mathrm{D}$

COOT N94-125: CT ID

Turnaround

Idle
100

25

100

38

97

360

$-1+2$ 
DECLASSIFIED

3,6 CF Q 6O\% Exficions:

$2000 T$ TE TI $\div 18 \mathrm{~T} / D$

$500 T$ RESH $\div 18 T 1 D$

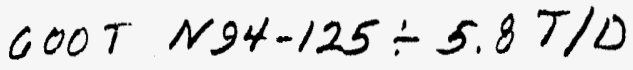

Turnaround

Idle
Days

112

28

104

38

78

P23:2

Toto l

360

Following is a list - rot very crigivial - of actions that might be considered to reduce: ARHCi costs when the lou precessing load develops after recovery from the effects of the thor sum. $233 \mathrm{U}$ processing campaign!

- Partial seyuintial operation followed by full sapiential operation

- Five -day chicest separation of Puree-- and possibly $B$ plant

- 10 days on and 4 days off at Puree

- Vacation shutdown

-Reorganization: of effort

- Deliberate "de-fatting"

Sequential Operation

We have been over this ground pretty thoroughly.. After the Th-233U campaign is completed and. Puree becomes about one-third idle, I suspect both the AEC and ARHCO will start considering. the sequential mode more seriously-- not "can we get .t it", but rather, "what is required tot it going.".

Eire-day Week Operation of Durex

If Puree can perform at a 60 percent efficiency on a 5 -day week plan, then, at 4.0 CF, this might go. The third table above shows 97 idle days per year. For a 365 day $y$ lar, the Idlatimo is 102 days. This is almost equal th the $52 \times 2=104$ days down time per year that would be experiesend with the 5-day week operation. Shouln't Murex test more?

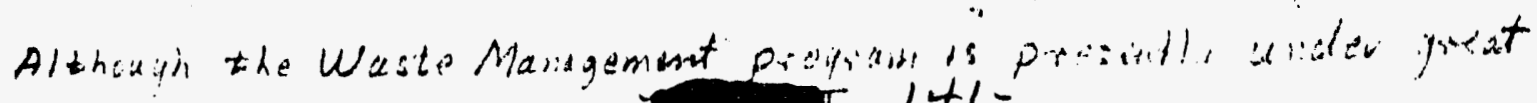
$-1+1-$ 


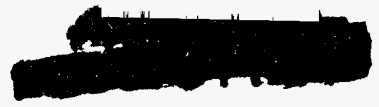

Pali:

pressure, a 5-day we for Waste Manaismant mien not be unversinable two or three n years from now.

10 Days on, 4 Days off at Purer

This may not be the worst proposal in the list. I de not believe serious consideration car be avoided. However the savings may be small.

Vacation Shutdirum

The above tables show that Purer can in the future shat down for a month for vacations. In theory, every twat th men (assuming 4 week vacation) could be removed from the payroll. This plan plus a less generous prevision of replacemuts for absences of other types could result in som savings that meiny be worthwhile. We can risk a little mora overtime burt fer each $\$ 12,000$ we reduce the payroll.

Reorganization of Effort and Deliberate. De-fatting

These two items amount to the same thing and raise these questions:

- How long hes it been since the basic organizational concepts of CPDibeen theraugily examined as id analyzed? $T_{s}$ the? Job we do the same as. when GF decentralized everything? Have the adicistments made from time-to-zine to accomode change been thoroughly integrated into a unified concept?

- Would all jobs that exist still exist if closely examined for necessity and justification? Are we getting the best use from those that exist?

- Doss the business in its tic live justify all the technical effort it gets? Do we already know enough to contiriec. efficiently to the end?

$-142-$ 


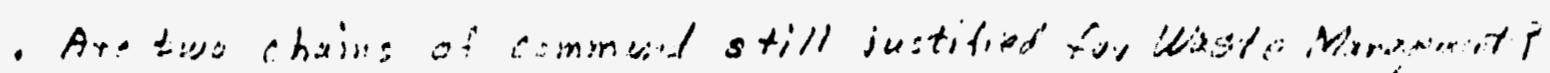
- What are the incontives for is ollco to improve efficioncis? Are they enough to go beyoud establishisigy an iming and being hand-nosed? 


\section{Distribution}

H I. M. K. Hermon

2. M. B. Alford

3. V. R. Chapman

Date: September 10, 1970

This document consisis of

To: M. K. Harmon

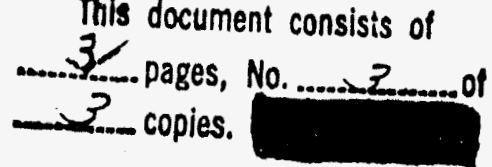

From: V. R. Chapman ifl

Subject: B PLANT-PUREX SEQUENTIAL OPERATION

The attached chart illustrates B Plant-Purex sequential operation using the latest available rates for acid sludge preparation and for the $B$ Plant SX extraction columns. The rate for SX processing of Purex acid sludge (PAS) assumes omission of the head-end process. The schedule is built around first priority for sludge mining and PAS processing.

In sumnary, the 360 days of the year are used as follows:

Tons Gal Days

Purex
$K$ Reactor fuels
1200
N Reactor fuels
352
$-\quad 44$
$-\quad 44$

B Plant

\section{PAW \\ ZAW \\ PAS}

Turnaround (24)

TOTAT

Acid sludge mining
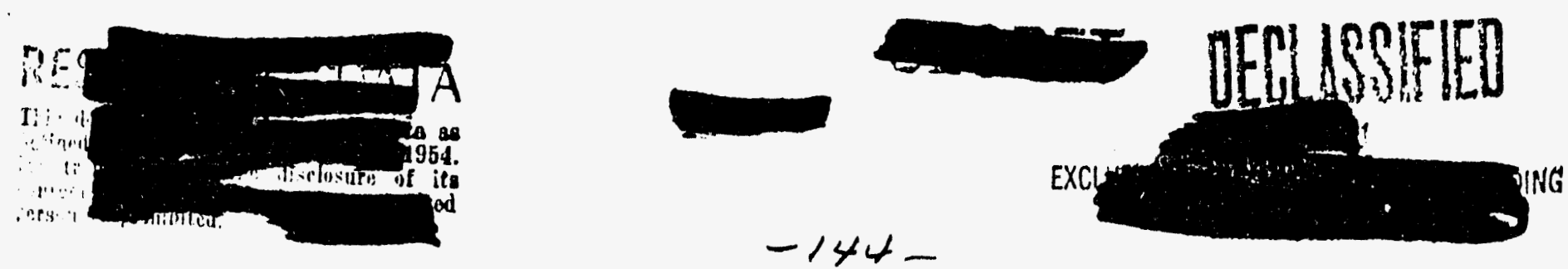

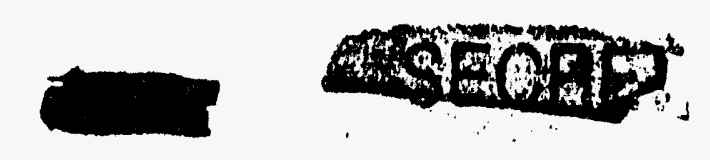

ROLGH DRAFT

Page

It is obvious from these data that the sequential operation plan is out until one of the f'ollowing occurs:

1. PAS processing is completed,

2. The load from either $\mathrm{K}$ Reactor or $\mathrm{N}$ Reactor disappears, or

3. SX processing rates are significantly increased and a successful head-end process (which reduces volume) is developed for PAS.

VRC $: m k I$

Attachment 


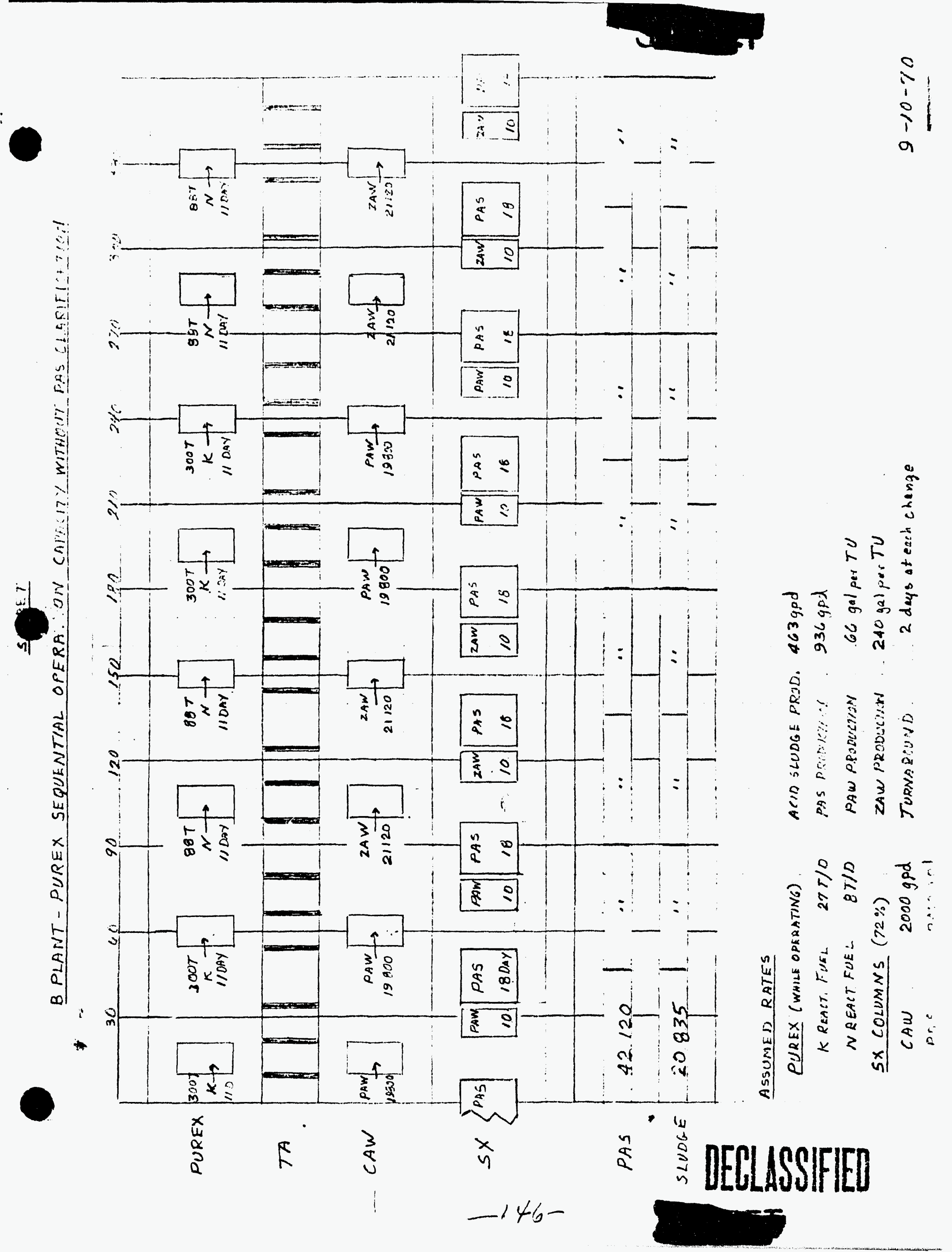



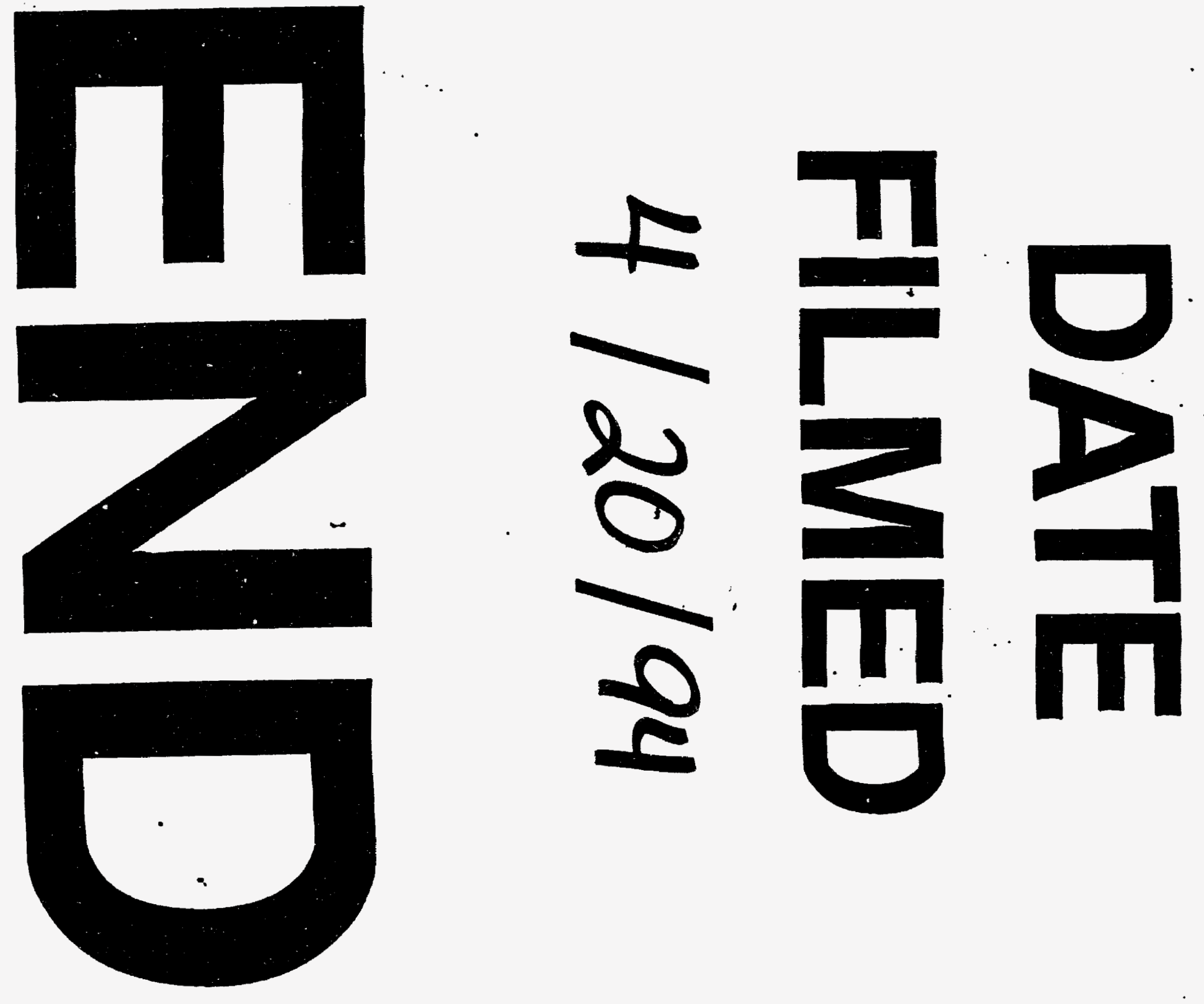